UNIVERSIDADE DE SÃO PAULO

INSTITUTO DE GEOCIÊNCIAS

\title{
CARACTERIZAÇÃO MATERIAL, TEXTURAL E EXECUTIVA DA PINTURA MURAL ALEGORIA AO DESENVOLVIMENTO INDUSTRIAL PAULISTA DE FULVIO PENNACCHI
}

\section{PATRICIA MARQUES MAGON}

Orientadora: Prof $\stackrel{a}{\text { a }}$ Drª . Eliane Aparecida Del Lama

Dissertação de Mestrado

№ 775

\author{
COMISSÃO JULGADORA \\ Dra . Eliane Aparecida Del Lama \\ Dra . Claudia Terezinha de Andrade Oliveira \\ Dra . Mirian Cruxen Barros de Oliveira
}

SÃO PAULO

2017 
Autorizo a reprodução e divulgação total ou parcial deste trabalho, por qualquer meio convencional ou eletrônico, para fins de estudo e pesquisa, desde que citada a fonte.

Ficha catalográfica preparada pelo Serviço de Biblioteca e Documentação do Instituto de Geociências da Universidade de São Paulo

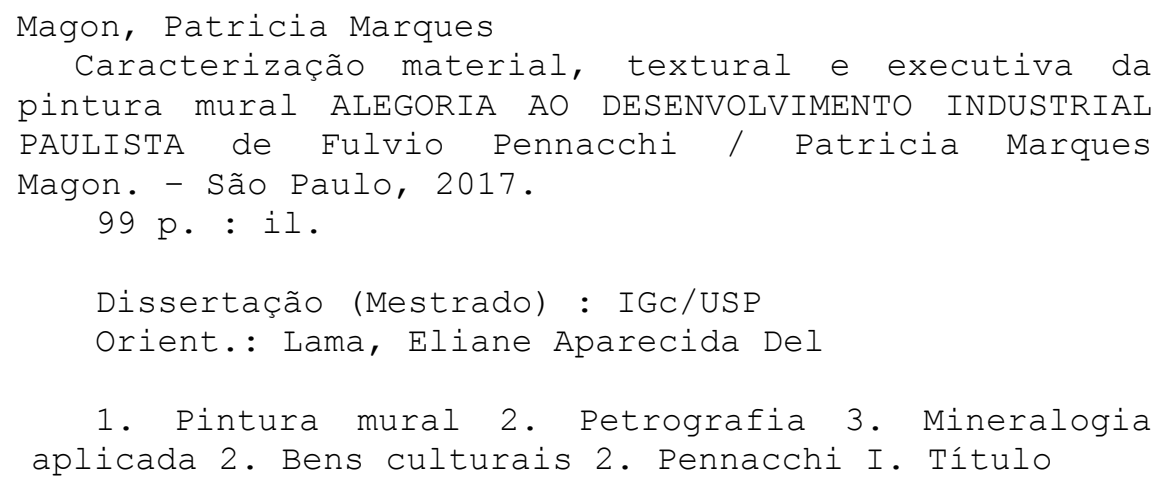


Dedico este trabalho a todos que se empenham em valorizar a cultura e a educação neste nosso país tão carente, que é o Brasil. 


\section{AGRADECIMENTOS}

À FAPESP - Fundação de Amparo à pesquisa do Estado de São Paulo - pelo apoio ao projeto de pesquisa no qual o presente trabalho se insere, através do processo número 2015/10858-8.

Ao CNPq - Conselho Nacional de Desenvolvimento Científico e Tecnológico - pela bolsa de estudos concedida.

À Profa. Dra. Eliane Del Lama, não só pela orientação no trabalho, mas por me proporcionar tantas oportunidades neste caminho! Obrigada!

À Giovanna Pennacchi e ao Valério Pennacchi, pelo apoio dado a este trabalho.

A todos os queridos e dedicados técnicos dos laboratórios do Instituto de Geociências da USP, pessoas sempre dispostas a nos ajudar.

Ao Prof. Fabio Ramos e ao Geólogo Marcelo Pecchio, não só por se disporem a ajudar sempre, mas também por terem sido os grandes inspiradores de minha procura por este trabalho. 


\section{RESUMO}

O presente trabalho apresenta estudo de amostras da pintura mural Alegoria ao Desenvolvimento Industrial Paulista do artista Fulvio Pennacchi. Trata-se de mural confeccionado com a técnica do afresco, e variações. Esta técnica envolve o uso de materiais de origem mineral, tanto no suporte quanto para os pigmentos - isso justifica as análises terem sido feitas sob a ótica da Geologia. Sobre a relevância do artista, Fulvio Pennacchi é considerado importante muralista de sua época, sendo um dos pioneiros na produção de afrescos no Brasil. A obra, que mede $7 \mathrm{~m} \times 11 \mathrm{~m}$, feita no ano de 1954, foi retirada do local onde foi originalmente confeccionada, em decorrência de incêndio que acometeu o imóvel. Engenheiros especializados a removeram e transportaram, e hoje se encontra guardada aguardando restauração. Por meio de dados coletados usando microscópio petrográfico, microscópio eletrônico de varredura e fluorescência de raios $X$, foi possível estabelecer a estratigrafia, as texturas, a mineralogia e composições químicas de três trechos do mural. O uso de lanterna de radiação ultravioleta nas superfícies pictóricas figura como método complementar. Os dados aqui expostos podem servir de apoio ao processo de restauração da obra, além de contribuir tanto para o aprimoramento dos protocolos de análise de obras artísticas, quanto para o registro histórico de técnicas de pintura mural ao longo dos tempos.

PALAVRAS-CHAVE: pintura mural, Pennacchi, petrografia 


\section{ABSTRACT}

The present work presents a study of samples of the mural painting Alegoria ao Desenvolvimento Industrial Paulista, by the artist Fulvio Pennacchi. It was painted with the fresco technique, and variations. This technique involves the use of materials of mineral origin, both in the support and for the pigments - this justifies the analyses been made from the perspective of Geology. About the artist's relevance, Fulvio Pennacchi is considered an important muralist of his time, being one of the pioneers in the production of frescoes in Brazil. The mural, measuring $7 \mathrm{~m} \times 11 \mathrm{~m}$, painted in 1954, was removed from where it was originally made, in consequence of a fire that affected the place. Specialized engineers removed and transported it, and today it is stored awaiting restoration. The stratigraphy, the textures, the mineralogy and the chemical compositions of three sections of the mural were established through data collected using petrographic microscope, scanning electron microscope and $X$ ray fluorescence. The use of ultraviolet lamp on the pictorial surfaces was a complementary method. The data presented here can support the process of restoration of the mural, as well as contribute to the improvement of protocols for the analysis of works of art, and to the historical record of mural painting techniques over time.

KEYWORDS: mural painting, Pennacchi, petrography 


\section{SUMÁRIO}

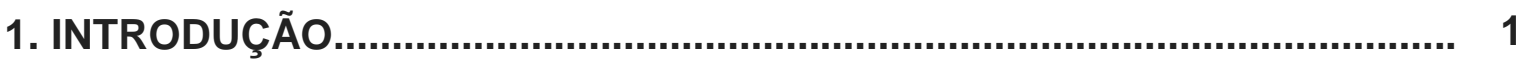

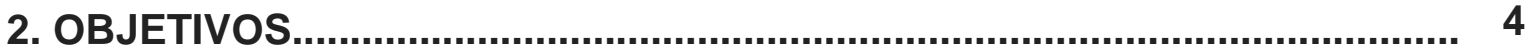

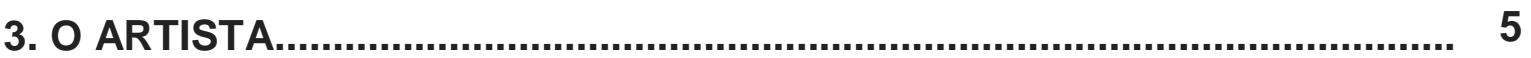

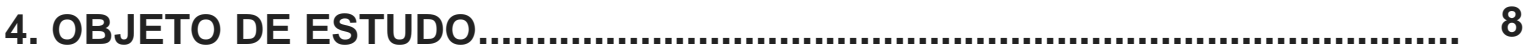

5. MATERIAIS E MÉTODOS....................................................................... 11

5.1 Análise macroscópica.................................................................... 11

5.1.1 Lupa USB com câmera acoplada............................................. 11

5.1.2 Lupa estereoscópica............................................................. 11

5.2 Análise microscópica e elementar (estratigrafia)............................. 12

5.2.1 Microscópio Petrográfico.............................................................. 12

5.2.2 Embutimento das amostras para MEV/EDS.................................. 12

5.2.3 Microscópio Eletrônico de Varredura (MEV) e Espectrômetro por Energia Dispersiva (EDS) ............................................................. 13

5.3 Análise elementar de superfície (Fluorescência de Raios X)............. 15

5.4 Análise de superfície sob radiação UV ............................................. 15

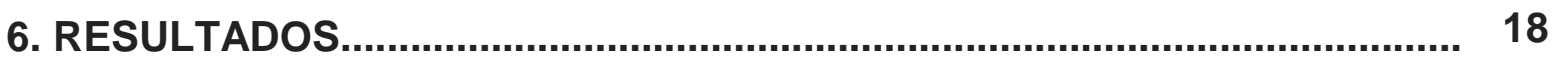

6.1 AMOSTRA 01 ............................................................................ 19

6.1.1 DESCRIÇÃO MASCROSCÓPICA................................................ 19

6.1.2 DESCRIÇÃO PETROGRÁFICA............................................... 21

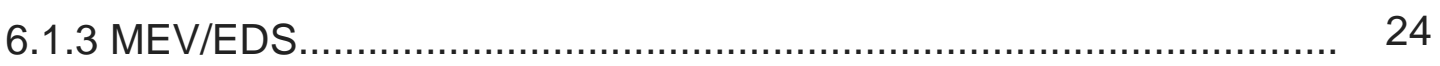

6.1.3a MEV/EDS - CORTE ESTRATIGRÁFICO................................ 24

6.1.3b MEV/EDS - SUPERFÍCIE PICTÓRICA................................... 32

6.1.4 FLUORESCÊNCIA DE RAIOS X............................................... 34

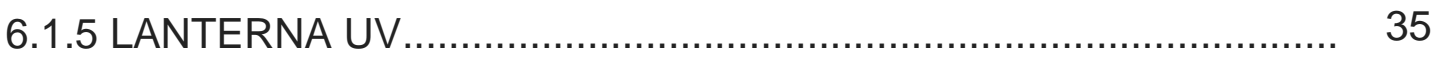

6.1.6 CONCLUSÕES SOBRE A AMOSTRA 01................................... 36

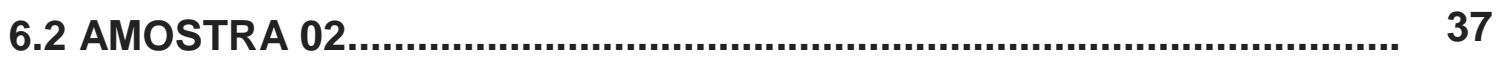

6.2.1 DESCRIÇÃO MASCROSCÓPICA................................................ 37

6.2.2 DESCRIÇÃO PETROGRÁFICA.................................................... 39

6.2.3 MEV/EDS - CORTE ESTRATIGRÁFICO...................................... 42

6.2.4 FLUORESCÊNCIA DE RAIOS X............................................... 49 
6.2.5 LANTERNA UV .................................................................... 50

6.2.6 CONCLUSÕES SOBRE A AMOSTRA 02 .................................... 51

6.3 AMOSTRA 03............................................................................... 52

6.3.1 DESCRIÇÃO MASCROSCÓPICA................................................ 52

6.3.2 DESCRIÇÃO PETROGRÁFICA..................................................... 54

6.3.3a MEV/EDS - CORTE ESTRATIGRÁFICO....................................... 55

6.3.3b MEV/EDS - SUPERFÍCIE PICTÓRICA........................................ 60

6.3.4 FLUORESCÊNCIA DE RAIOS X................................................. 61

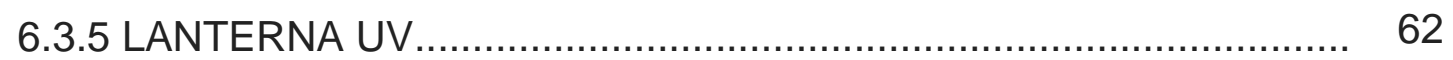

6.3.6 CONCLUSÕES SOBRE A AMOSTRA 03...................................... 63

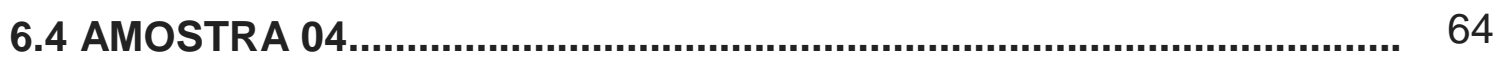

6.4.1 DESCRIÇÃO MASCROSCÓPICA............................................... 64

6.4.2 DESCRIÇÃO PETROGRÁFICA................................................. 66

6.4.3 MEV/EDS - CORTE ESTRATIGRÁFICO...................................... 69

6.4.4 FLUORESCÊNCIA DE RAIOS X................................................. 74

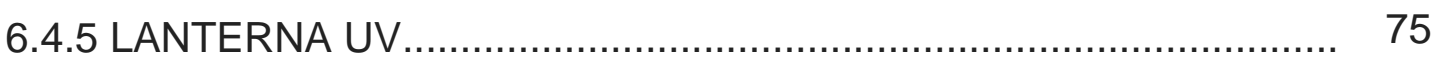

6.4.6 CONCLUSÕES SOBRE A AMOSTRA 04.................................... 76

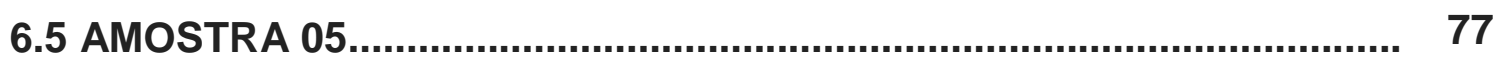

6.5.1 DESCRIÇÃO MASCROSCÓPICA................................................. 77

6.5.2 DESCRIÇÃO PETROGRÁFICA.................................................... 78

6.5.3a MEV/EDS - CORTE ESTRATIGRÁFICO..................................... 79

6.5.3b MEV/EDS - SUPERFÍCIE PICTÓRICA....................................... 86

6.5.4 FLUORESCÊNCIA DE RAIOS X.............................................. 89

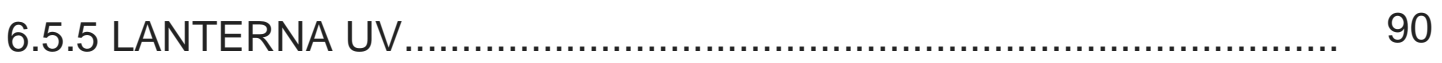

6.5.6 CONCLUSÕES SOBRE A AMOSTRA 05................................... 91

7. COMPARAÇÕES COM TRABALHOS ANTERIORES................................ 92

8. CONCLUSÕES................................................................................... 95

9. REFERÊNCIAS BIBLIOGRÁFICAS....................................................... 97 


\section{INTRODUÇÃO}

O patrimônio cultural de uma nação é de reconhecida importância para o fortalecimento da identidade do povo, portanto para a afirmação da cidadania. Essa consciência tem sido crescente em nosso país.

Segundo o artigo 216 da Constituição Federal, "Constituem patrimônio cultural brasileiro os bens de natureza material e imaterial, tomados individualmente ou em conjunto, portadores de referência à identidade, à ação, à memória dos diferentes grupos formadores da sociedade brasileira".

Além da seleção e catalogação dos bens, é necessário que sua manutenção seja constante e efetiva. No que se refere ao patrimônio material, os processos de preservação, conservação e restauração envolvem diversas áreas do conhecimento, exigindo sempre a atuação de equipes multidisciplinares. A Geologia tem muito a contribuir com o tema, através de procedimentos tais como: caracterização de argamassas e identificação de pigmentos de pinturas artísticas; identificação das rochas usadas em construções históricas; estudo de intemperismo de monumentos rochosos; caracterização mineralógica de azulejos antigos; dentre outros (Reys et al., 2008; Del Lama, 2009).

Quanto aos materiais utilizados para a confecção de pinturas murais - natureza do objeto de estudo deste trabalho - é importante frisar que são prevalentemente de origem mineral, com exceção de uns poucos pigmentos e ligantes orgânicos nos casos das pinturas executadas a secco (método brevemente descrito adiante). Em uma superfície parietal destinada a receber uma pintura, (podendo esta superfície ser constituída de diferentes materiais tais como tijolos ou pedras), a primeira etapa do trabalho é a aplicação das camadas de massas preparatórias, que têm as funções de regularização e/ou texturização, sendo a última camada preparada especialmente para receber os pigmentos. Essas massas são compostas principalmente por: aglomerante (a cal é tida como aglomerante por excelência); agregado (areias); outros materiais podem ser adicionados para fornecer atributos como plasticidade, retardo ou aceleração de pega, tais como argilas ou cimento. Os pigmentos variam conforme a técnica escolhida, se a fresco, mezzo fresco ou a secco. No caso dos afrescos, a camada de argamassa de cal que serve como suporte para a pintura recebe os pigmentos enquanto ainda está úmida; durante a 
secagem, a cal hidratada $\left(\mathrm{Ca}(\mathrm{OH})_{2}\right)$ reage com o $\mathrm{CO}_{2}$ atmosférico, cristalizando carbonato de cálcio $\left(\mathrm{CaCO}_{3}\right)$ e fixando os pigmentos por coesão, sendo estes os de origem mineral para que resistam à causticidade da presença do $\mathrm{Ca}(\mathrm{OH})_{2}$ em meio aquoso. Sendo a secco, a camada que recebe os pigmentos encontra-se seca, dessa forma os pigmentos devem estar misturados a uma emulsão que proporcionará sua adesão ao suporte. Já o mezzo fresco é feito com o suporte em adiantado estado de carbonatação, sendo adicionada água de cal aos pigmentos para que aconteça a fixação das cores (Cennini, 1398; Tirello, 2001; Tirello, 2006; Del Lama et al., 2009). Mora et al. (1984) não aconselham o uso do termo mezzo fresco, argumentando referir-se não a uma técnica mas sim a uma mistura de técnicas para obtenção de texturas e efeitos específicos, não possíveis com a técnica do afresco, usando a própria cal como aglutinante de maneira que os pigmentos nesta água de cal não se fixarão por coesão na superfície pictórica original, e sim formarão uma nova camada sobre essa superfície, à maneira da pintura a secco. Em entrevista a André (1989), Fulvio Pennacchi explica que costumava preparar sua água de cal para ser misturada a pigmentos - Wilhelm (2006) observa que essa fala revela que o artista usava o que a autora chama de técnica da têmpera a cal, aplicando essa mistura sobre superfícies secas.

Para que se possa desenvolver estratégias de restauração e conservação satisfatórias, ou seja, para que o restaurador/conservador seja capaz tanto de reconstituir partes das obras, quanto de aplicar métodos e materiais apropriados para o tratamento de danos (reduzindo ou eliminando suas causas) ou determinar medidas preventivas adequadas, deve ser feita a avaliação completa e precisa tanto dos materiais e modo de feitura da obra, quanto da natureza e causa dos danos, incluindo avaliação de possíveis restauros anteriores (Dasser, 1991).

Mesmo após terem passado pelo processo de restauro, pinturas parietais devem ser submetidas a avaliações periódicas - já é de conhecimento geral casos em que as obras sofrem aceleração dos processos de degradação após a restauração, em função principalmente da utilização de métodos e materiais inadequados (Matteini, 1991).

O Instituto de Geociências (IGc) da Universidade de São Paulo, através do Programa de Pós-Graduação em Mineralogia e Petrologia, abarca projetos de pesquisa voltados ao patrimônio artístico, tendo como objetivos principais 
caracterização físico-química e mineralógica destes bens, juntamente com a descrição do modo de feitura das obras, contribuindo tanto com informações relevantes para tomadas de decisão relacionadas à preservação, conservação e restauração, quanto com o registro histórico-cultural do patrimônio artístico ao longo do tempo.

Outras pinturas murais do artista Fulvio Pennacchi foram objetos de estudo do Instituto de Geociências da USP, em conjunto com o CPC - Centro de Preservação Cultural (órgão subordinado à Pró-Reitoria de Cultura e Extensão Universitária da Universidade de São Paulo), sendo eles os murais A Anunciação da Virgem (1947) e Ceia de Emaús (1947), localizados na Capela do Hospital das Clínicas da Faculdade de Medicina da USP. Entre 2005 e 2006 foi feito um estudo detalhado destas obras, envolvendo pesquisa histórica e investigação técnica in loco e em laboratório. Algumas das ferramentas utilizadas neste estudo foram microscopia petrográfica, microscopia eletrônica de varredura, espectroscopia por dispersão de energia, difração de raios $X$ e microssonda eletrônica. $O$ resultado, além de um diagnóstico do estado de conservação da obra, foi principalmente o entendimento da morfologia da superfície e da composição e modo de aplicação dos materiais (Tirello \& Del Lama, 2005; Tirello, 2006).

Em 2007 foram feitos nestes mesmos murais estudos sobre a cristalização de sais em superfície (eflorescências), mostrando que parte destas compromete a integridade da obra. Isso trouxe importantes novos detalhes ao diagnóstico do estado de conservação. Aqui também foram utilizados, além dos estudos in loco, o microscópio eletrônico de varredura com EDS e a difração de raios X (Del Lama et al., 2007).

Finalmente, em 2009 foram publicados dados reunidos dos anos de pesquisa sobre os murais citados acima ( $A$ Anunciação da Virgem e Ceia de Emaús), incluindo dentre os vários resultados imagens (MEV) que mostram áreas da obra executadas a fresco e outras a secco; as diferenças do comportamento das eflorescências nas duas obras e suas consequências; entre outros (Del Lama et al., 2009). O presente trabalho vem contribuir com esse importante conjunto de dados, e compara os resultados deste com os trabalhos prévios nas obras de Fulvio Pennacchi. 


\section{OBJETIVOS}

Este trabalho tem como objetivo principal estabelecer a estratigrafia, mineralogia, composição química e texturas do mural Alegoria ao Desenvolvimento Industrial Paulista do artista Fulvio Pennacchi. De posse destas informações, será possível aperfeiçoar as técnicas e materiais empregados quando for iniciado processo de restauração da obra.

Outro objetivo é contribuir com o aprimoramento dos protocolos de análise material de obras artísticas, para a aplicação cada vez mais efetiva dos diferentes métodos analíticos existentes em obras como a estudada neste trabalho, e similares.

As conclusões sobre os modos de feitura desta obra são de grande valor para incrementar o registro histórico das técnicas de pintura mural ao longo dos tempos. 


\section{O ARTISTA}

Fulvio Pennacchi nasceu na Itália em 1905. Em 1928 graduou-se em pintura na Real Academia de Arte Augusto Passaglia, em Lucca, e no ano seguinte mudou-se para o Brasil, primeiramente para a cidade de Santos, SP, depois para a capital São Paulo (Pennacchi, V.A. in <www.fulviopennacchi.com>).

No início, paralelamente aos esforços de se manter e crescer como artista, trabalhou como pedreiro, açougueiro e operário. Ao longo da vida adquiriu notoriedade e grande importância, tendo sido bastante festejado, participando de inúmeros eventos, exposições e homenagens nas últimas décadas de sua vida (Quedas, 2004; Pennacchi, V.A. in <www.fulviopennacchi.com>).

Na década de 1930, seu atelier no Palacete Santa Helena, localizado na Praça da Sé em São Paulo (demolido na década de 1970) rendeu-lhe a participação em um importante grupo de artistas, que mais tarde ficou conhecido como Grupo Santa Helena. Junto com Aldo Bonadei, Francisco Rebollo Gonsales, Clóvis Graciano, Manoel Martins, Humberto Rosa, Alfredo Rizzotti, Alfredo Volpi e Mário Zanini, formou uma espécie de coletivo, surgido de maneira espontânea, onde trocavam experiências e debatiam conceitos (Pennacchi, V.A. in <www.fulviopennacchi.com>).

Além das telas, dos desenhos e das cerâmicas, foi um artista renomadamente dedicado às pinturas murais, primeiro a óleo e posteriormente a fresco. Na Itália já havia tomado contato com a produção de murais com a técnica da têmpera (Wilhelm, 2006; Pennacchi, V.A. in <www.fulviopennacchi.com>). Segundo Quedas (2004), Pennacchi foi pioneiro no Brasil na confecção de murais em espaços públicos, iniciando esse trabalho com a importante obra a óleo $A$ História da Imprensa, feita no final da década de 1930 na antiga sede do jornal A Gazeta, na Avenida Cásper Líbero em São Paulo (hoje o imóvel abriga divisão do Superior Tribunal Militar).

Sem conhecimento formal prévio na arte das pinturas murais a fresco, foi na década de 1940 que Pennacchi iniciou seus experimentos com esta técnica. Autodidata, recebeu a ajuda de importantes figuras, como o já consagrado artista Galileo Emendabili, que abriu seu ateliê para que Pennacchi pudesse realizar seus 
experimentos, assim como o industrial Cândido Cerqueira Leite, que além de disponibilizar os fornos de sua indústria para queima de cerâmicas, facilitou o acesso de Pennacchi a materiais como as argilas brasileiras, usadas tanto nas cerâmicas quanto como pigmentos nos afrescos (Bardi, 1980).

Gozando de prestígio junto ao círculo dos imigrantes italianos de São Paulo, inclusive já sendo nesta época professor do Colégio Dante Alighieri, foi requisitado para participar do projeto de concepção e construção da Igreja Nossa Senhora da Paz, na baixada do Glicério, bairro da Liberdade em São Paulo. Acabou sendo o autor do projeto arquitetônico, além de conceber e realizar todos os afrescos do interior do edifício. Sendo um dos pioneiros do afresco no Brasil, alguns consideram que foi a partir deste trabalho que se iniciou em São Paulo o interesse por esse tipo de arte (Bardi, 1980).

Produziu muitos murais a fresco em residências particulares, nesse período da história de São Paulo em que muitas famílias enriqueceram em função das plantações de café e do início da industrialização, e que segundo Cenni (2003), "não podiam tolerar sequer um palmo de paredes sem enfeites" em suas casas.

Parte dos pigmentos utilizados por Pennacchi nos afrescos era importada, como por exemplo o azul cobalto, e parte era encontrada aqui, como argilas vermelhas e amarelas (Andre, 1989; Wilhelm, 2006). Segundo Wilhelm (2006), Pennacchi não se concentrou em aplicar apenas a técnica precisa do afresco tradicional - chamado de buon fresco - mas inovou, mesclando com a técnica chamada de mezzo fresco, aplicando sobre o reboco já seco ou semisseco aguadas de cal, sobre as quais então aplicava os pigmentos. Costumava preparar sozinho suas argamassas e pigmentos (Quedas, 2004).

Pennacchi, assim como seus colegas do Grupo Santa Helena, não se alinhava ao estilo dos vanguardistas, tampouco seguia regras acadêmicas. Sobre isso comentou Pennacchi:

"Nós, os assim ditos pintores proletários, não concordávamos nem com os acadêmicos e muito menos com os presunçosos inovadores. Gostávamos de pintar paisagens urbanas, 
naturezas mortas ou figuras ao vivo. Eu gostava de pintar as vidas dos Santos, de gente humilde e sofredora, por isso preferia Cézanne, Segall, Portinari e mais os meus mestres toscanos do Trezentos e do Quatrocentos". (Bardi, 1980, pg. 14).

Formou família e permaneceu no Brasil até sua morte em 1992. 


\section{OBJETO DE ESTUDO}

A pintura mural objeto deste estudo, intitulada Alegoria ao Desenvolvimento Industrial Paulista, foi feita no ano de 1954 na antiga sede do Banco Auxiliar de São Paulo, na Avenida Duque de Caxias, medindo $7 \mathrm{~m} \times 11 \mathrm{~m}$. A Figura 1 mostra projeto da obra feito por Pennacchi em guache no ano de 1953, imagem esta retirada do livro Fulvio Pennacchi (Bardi, 1980). Escrito à mão na porção inferior direita, há os dizeres: "Estudo final mural executado Banco Auxiliar ag. Duque de Caxias Executado a fresco S. Paulo". A legenda que consta no livro faz referência à imagem como projeto definitivo do mural.

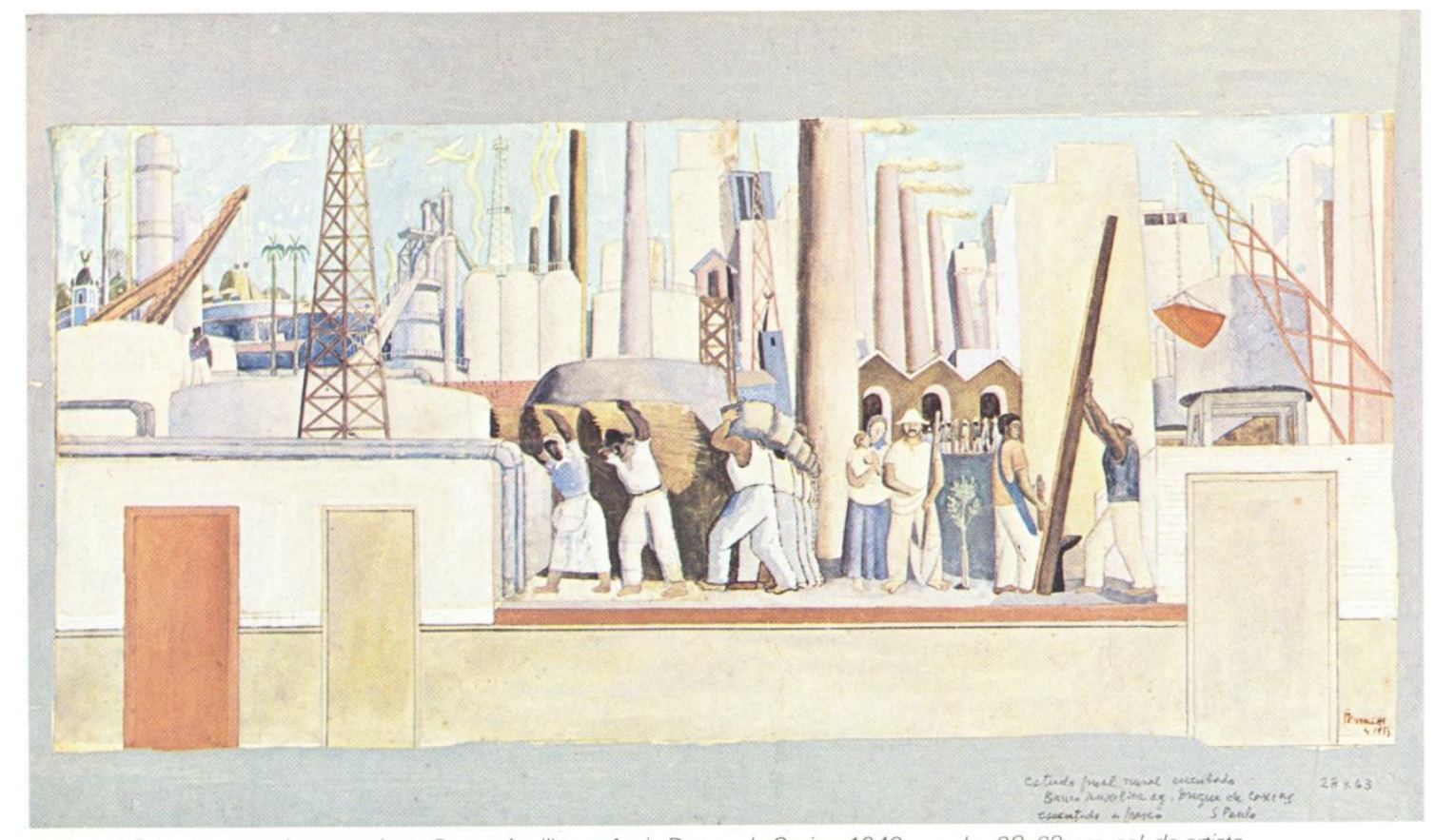

Projeto definitivo do mural executado no Banco Auxiliar, agência Duque de Caxias, 1949, guache, $28 \times 63 \mathrm{~cm}$, col. do artista.

Figura 1: Projeto do mural em guache sobre cartão. Fonte: Bardi, 1980.

Com a saída do Banco Auxiliar do imóvel, a obra passou alguns anos escondida atrás de painéis publicitários, tendo sido o imóvel mais recentemente ocupado por uma loja de autopeças (Figuras 2 e 3). 


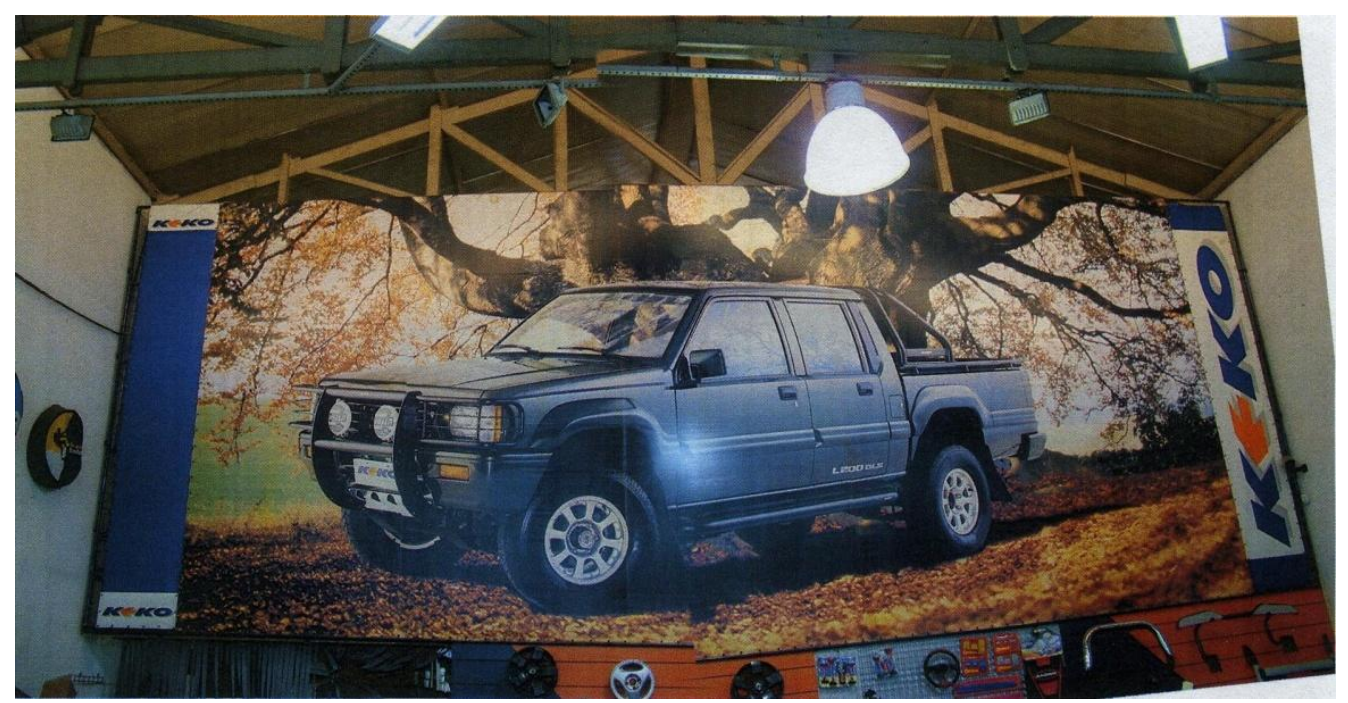

Figura 2: Painel publicitário sobre a obra, na loja de autopeças. Foto: Eliane Del Lama.

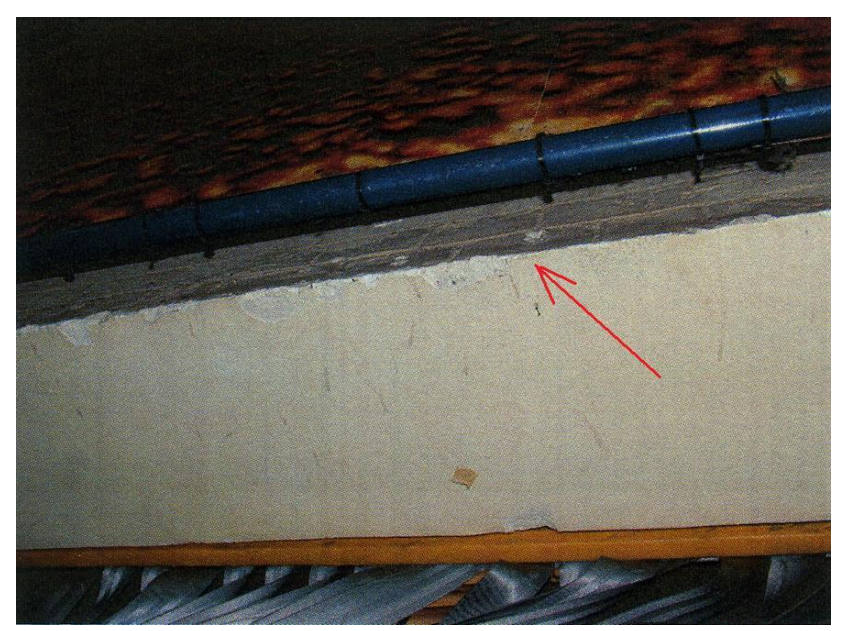

Figura 3: Seta indica detalhe da extremidade inferior da obra, escondida sob painel publicitário. Foto: Eliane Del Lama.

Em 2009, o local sofreu um incêndio, que danificou partes do mural. Na Figura 40 mural é visível ao fundo. Entre outros danos, parte da obra desabou (indicada pela seta vermelha na Figura 4), tendo sido dali coletadas as cinco amostras estudadas no presente trabalho. 


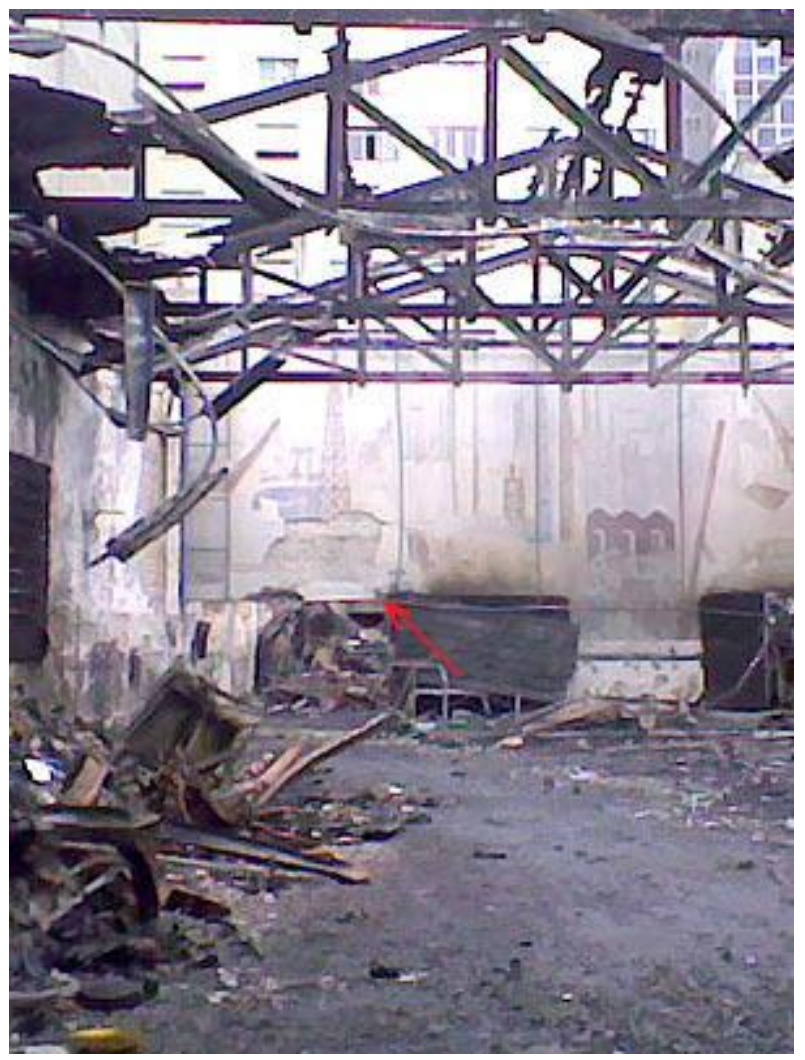

Figura 4: Obra após o incêndio. Fonte: https://noticias.terra.com.br/brasil/cidades/vcreporter-incendio-em-loja-revela-obra-de-arte-em-saopaulo,294b68f40d94b310VgnCLD200000bbcceb0aRCRD.html

Após o incêndio, a obra foi removida do local por empresa especializada, e atualmente se encontra guardada aguardando intervenção de restauro. 


\section{MATERIAIS E MÉTODOS}

As amostras do mural utilizadas neste estudo foram coletadas logo após o incêndio ocorrido no imóvel onde o mural se encontrava originalmente - neste momento, parte da obra desabou (Figura 4), e dentre os fragmentos, cinco foram escolhidos e trazidos para a universidade para os devidos estudos. Vale ressaltar que a família do artista foi contatada e nos deu autorização para o uso e publicação dos dados.

Para as análises foram utilizados os seguintes equipamentos/métodos: lupa USB com câmera acoplada; lupa estereoscópica; microscópio petrográfico; embutimento das amostras para MEV/EDS utilizando: cortadeira de precisão, câmara de vácuo e politriz; microscópio eletrônico de varredura (MEV) e espectrômetro por energia dispersiva (EDS); espectrômetro de fluorescência de raios X; lanterna UV.

\subsection{Análise macroscópica}

Para a análise macroscópica foram utilizadas lupas USB e estereoscópica.

\subsubsection{Lupa USB com câmera acoplada}

As imagens usadas para as descrições macroscópicas presentes no item 'Resultados' foram feitas com Lupa USB com câmera acoplada, marca VEHO, modelo Discovery USB Microscope with 200x magnification/VMS-001 (Figura $5_{A}$ ) do Laboratório de Análises em Herança Cultural do Instituto de Geociências da Universidade de São Paulo.

\subsubsection{Lupa estereoscópica}

Previamente às análises em MEV, tanto os fragmentos evidenciando a estratigrafia das amostras, quanto os fragmentos de superfície, foram fotografados sob lupa estereoscópica Zeiss SV 11 acoplada a câmera fotográfica marca LEICA modelo MC170HD e software de captação de imagens LEICA QWIN 550, do Laboratório de Petrografia Sedimentar do Instituto de Geociências da Universidade de São Paulo. 


\subsection{Análise microscópica e elementar (estratigrafia)}

Para as análises microscópicas e elementares dos cortes estratigráficos das amostras, foram confeccionadas lâminas delgadas para análise em microscópio petrográfico, e fragmentos embutidos em resina para anállise em microscópio eletrônico de varredura (MEV) e espectrômetro por energia dispersiva (EDS).

\subsubsection{Microscópio Petrográfico}

Na Seção de Laminação do Instituto de Geociências da Universidade de São Paulo foram confeccionadas lâminas delgadas a partir de cada uma das amostras, sempre evidenciando o corte estratigráfico das mesmas. Para o preparo da lâmina, o material foi fatiado e colado em lâmina de vidro com Bálsamo do Canadá, lixado e polido até a espessura de $30 \mu \mathrm{m}$, e finalmente coberto por lamínula de vidro.

No Instituto de Geociências da Universidade de São Paulo, os microscópios utilizados para as descrições e captação de imagens foram o ZEISS Axioplan, disponível no Laboratório de Microscopia Petrográfica, e o ZEISS Axioplan 2, com câmera fotográfica acoplada marca LEICA modelo MC170HD, acoplados ao software LEICA Application Suite, do Laboratório de Petrografia Sedimentar.

No microscópio petrográfico de luz transmitida, a luz atravessa a amostra antes de atingir a objetiva, contando com dois polarizadores, um entre a fonte de luz e a amostra, outro entre a amostra e a lente objetiva. Esta configuração permite análise das propriedades ópticas do material em estudo, além das propriedades texturais e estruturais.

\subsubsection{Embutimento das amostras para MEV/EDS}

Para serem analisadas no MEV/EDS do Laboratório de Caracterização Tecnológica (LCT) da Escola Politécnica da Universidade de São Paulo, as cinco amostras passaram por processo de embutimento no Laboratório de Análises em Herança Cultural do Instituto de Geociências da Universidade de São Paulo. Para tal, primeiramente foram cortadas em fragmentos de aproximadamente $1 \mathrm{~cm}$ de diâmetro, colocando-se em evidência o corte estratigráfico das mesmas. Para este corte foi utilizada cortadeira de precisão marca BUEHLER modelo IsoMet 1000 Precision Saw, com serras de diamante marca BUEHLER modelo IsoMet Diamond 
Wafering Blades (Figura 6 A), nas seguintes condições: $200 \mathrm{~g}$ de peso e 700 rotações por minuto. As amostras foram então acondicionadas em recipientes de plástico marca BUEHLER modelo SamplKups, de $2,5 \mathrm{~cm}$ de diâmetro (Figura $5_{\mathrm{B}}$ ). Os recipientes foram previamente untados com óleo mineral (Nujol). Para recobrir as amostras foram utilizados resina e endurecedor (hardener) para embutimento da marca BUEHLER: EpoThin 2 Epoxy Resin 20-3440-032 e EpoThin 2 Epoxy Hardener 20-3442-016, respectivamente na proporção 2:1. Os recipientes foram então levados para câmara de vácuo marca BUEHLER modelo CAST N'VAC 1000 Castable Vacuum System (Figura $7_{\mathrm{B}}$ ) por aproximadamente 2 horas, para que pudessem ser eliminadas as bolhas de ar que se formam durante o preparo da resina. Respeitado o tempo de cura da resina, as amostras foram lixadas primeiramente a mão, com lixas d'água de granulação 240, 600 e 1200, para depois serem polidas em politriz marca BUEHLER modelo Minimet 1000 Grinder-Polisher (Figura $7 \mathrm{~A}$ ). Para o polimento, sobre papel abrasivo marca BUEHLER modelo CarbiMet SIC Abrasive Paper 36-02-0320, foi aplicada uma mistura de pasta diamantada marca Dinser granulação 1 a $4 \mu \mathrm{m}$, e óleo mineral. As condições do polimento foram: 2 libras a 10 rotações por minuto durante 10 minutos.

\subsubsection{Microscópio Eletrônico de Varredura (MEV) e Espectrômetro por Energia} Dispersiva (EDS)

Para as análises em MEV/EDS, foram utilizados dois laboratórios diferentes. O primeiro, onde foram realizadas as análises dos fragmentos de superfície das amostras, é o Laboratório de Microscopia Eletrônica de Varredura do Instituto de Geociências da Universidade de São Paulo, que conta com Microscópio Eletrônico de Varredura (MEV) marca LEO Electron Microscopy Ltd modelo LEO 440 e Espectrômetro de Energia Dispersiva (EDS) Oxford Instruments Ltd com detector de estado sólido do tipo $\mathrm{Si}(\mathrm{Li})$, acoplado ao software Luca 300. As condições analíticas foram: tensão de aceleração de $20 \mathrm{KV}$, distância de trabalho de $25 \mathrm{~mm}$, corrente de sonda de 1,5 nA, diâmetro do feixe de elétrons de 1,5 $\mu \mathrm{m}$. Para serem analisadas, as amostras foram fixadas com fita de dupla face de carbono, condutora de corrente elétrica, sobre stubes (porta amostras) de alumínio. As amostras devem ser preparadas antes de serem analisadas, através de um recobrimento por deposição de íons metálicos, para que se tornem condutoras e gerem melhores respostas do equipamento. Neste estudo foi utilizado o recobrimento com carbono, feito em 
evaporadora marca EDWARDS modelo AUTO 306 do Laboratório de Microssonda Eletrônica do Instituto de Geociências da Universidade de São Paulo.

O segundo laboratório, onde foram analisados os fragmentos dos cortes estratigráficos, é o Laboratório de Caracterização Tecnológica (LCT) da Escola Politécnica da Universidade de São Paulo, que conta com Microscópio Eletrônico de Varredura marca FEI modelo QUANTA FEG 650 e Espectrômetro de Energia Dispersiva BRUKER com detector tipo Silicon Drift Detector acoplado ao software QUANTAX ESPRIT 1.9. As condições analíticas foram: tensão de aceleração de 20 $\mathrm{KV}$, abertura de $30 \mathrm{~mm}$, corrente de feixe de $100 \mathrm{nA}$ e diâmetro do feixe de $5,5 \mu \mathrm{m}$. Para serem analisadas as amostras foram embutidas em resina (conforme metodologia exposta anteriormente) e recobertas com carbono em equipamento de recobrimento de amostras marca BAL-TEC modelo SCD050 também do Laboratório de Caracterização Tecnológica da Escola Politécnica da Universidade de São Paulo.

A microscopia eletrônica de varredura se dá pela interação de um feixe de elétrons com a superfície da amostra, produzindo elétrons e radiação coletados por detectores e convertidos em sinal de vídeo (Dedavid, 2007).

Dois tipos de imagens foram gerados para este trabalho: as originárias de elétrons secundários, e as de elétrons retroespalhados. As primeiras resultam em contraste de relevo e textura, revelando a topografia da amostra. Já as de elétrons retroespalhados apresentam contrastes em função do número atômico dos elementos - os mais leves respondem com imagens mais escuras, os mais pesados mais claras, produzindo diferenças de tonalidade geradas pelas diferenças composicionais.

O bombardeamento pelo feixe de elétrons faz com que a amostra emita espectros de raios $\mathrm{X}$ característicos, que são coletados pelo detector do EDS para identificação dos elementos presentes (Dedavid, 2007). 


\subsection{Análise elementar de superfície (Fluorescência de Raios X)}

Para as análises elementares de superfície, através do escaneamento superficial (da superfície pictórica) das amostras em Espectrômetro de Fluorescência de Raios X, foram coletados dados espectrométricos cobrindo elementos maiores, menores e alguns elementos traços. A intenção desta análise foi identificar a presença ou não de pigmentos e composição química da camada superficial das amostras, não importando suas quantidades absolutas, portanto optou-se por uma análise semiquantitativa não destrutiva.

$\mathrm{O}$ aparelho possui uma fonte que emite um feixe monocromático de raios $\mathrm{X}$ sobre a amostra, com poder de penetração da ordem de poucos micrômetros (esta baixa penetração é necessária neste caso, pois a intenção foi a identificação dos materiais que se encontram apenas em superfície). Esse feixe induz transições eletrônicas nos elementos presentes, que por sua vez respondem emitindo radiações com comprimentos de ondas característicos (Rizzuto, 2014), captados pelos detectores e organizados pelo software acoplado, que gera saída dos dados em forma de tabela.

O equipamento utilizado foi o disponível no Laboratório de Fluorescência de Raios $\mathrm{X}$ do Instituto de Geociências da Universidade de São Paulo, marca PANalytical modelo AXIOS MAX. Possui tubo de Rh (ródio), e opera com tensão acima de $60 \mathrm{kV}$ e corrente acima de $160 \mathrm{~mA}$, a uma potência máxima de $4 \mathrm{~kW}$. Os cristais analisadores são: PX-10 (varredura dos elementos entre K e U), LiF 220 (V-U), PE (Al-Cl), Ge (P, S e CL), PX 1 (O-Mg) e PX 8 (O-Mg). Detectores: de fluxo e de cintilação. O software usado para processar os dados foi o Omnian.

\subsection{Análise de superfície sob radiação UV}

Para observação das superfícies das amostras sob radiação ultravioleta, foi utilizada uma Lanterna UV LED ondas longas TritanTM 365 da Spectroline (Figura $6_{\mathrm{B}}$ ), do Laboratório de Análises em Herança Cultural do Instituto de Geociências da Universidade de São Paulo.

A radiação ultravioleta (comprimentos de onda menores que $400 \mathrm{~nm}$ ) pode provocar a luminescência: fenômeno produzido devido à propriedade de determinadas 
substâncias de absorver parte desta radiação, sofrendo transições eletrônicas - a perda do excesso de energia por esses elétrons, ao retomarem suas posições iniciais, podem gerar emissão de radiação de maior comprimento de onda em comparação com a radiação absorvida. A luminescência pode ser de dois tipos: fluorescência e fosforescência. A primeira caracteriza-se pela emissão de luz visível somente enquanto está presente a fonte de excitação; a segunda dá-se quando o material continua emitindo radiação mesmo quando essa fonte cessa. Esta técnica é de uso comum para diferenciar e/ou reconhecer materiais empregados em pinturas artísticas (Barrio, 2005).

A máquina fotográfica usada para captar as imagens das amostras sob radiação UV foi a da marca Panasonic modelo Lumix DMS-ZS7, resolução $12.1 \mathrm{MP}$, zoom óptico $12 x$ 

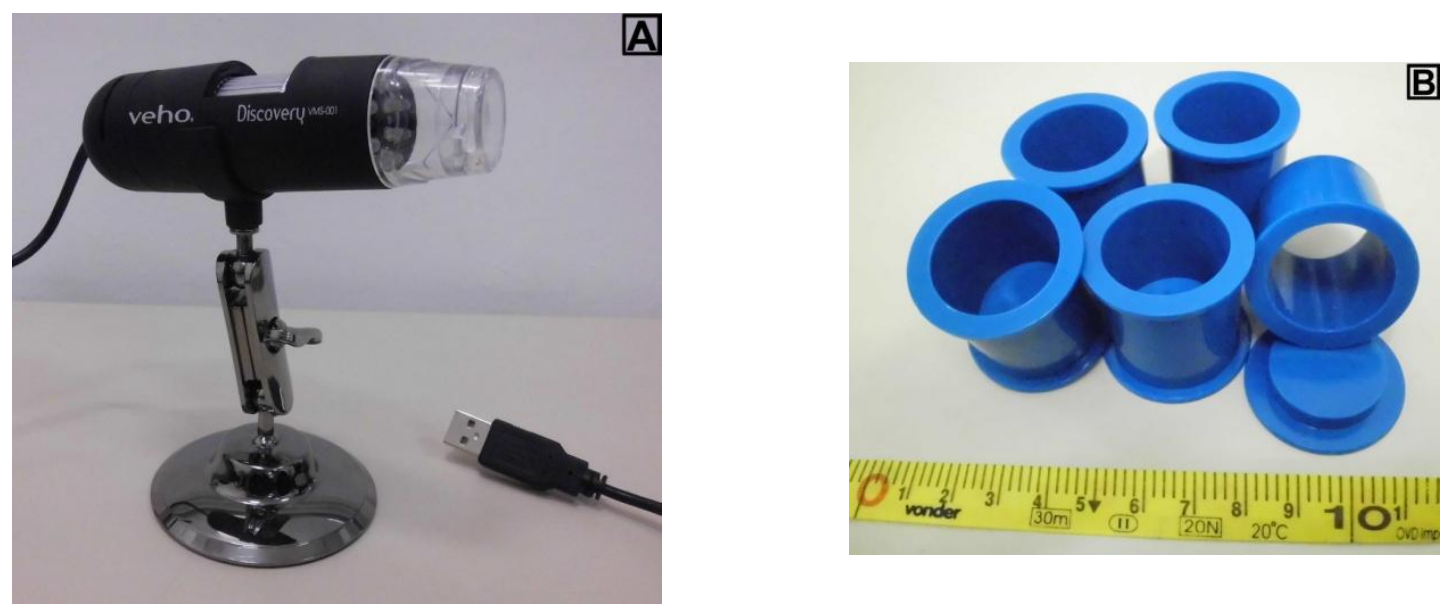

Figura 5A: Lupa USB com câmera acoplada. Figura 5B: Recipientes de plástico usados no processo de embutimento de fragmentos das amostras.
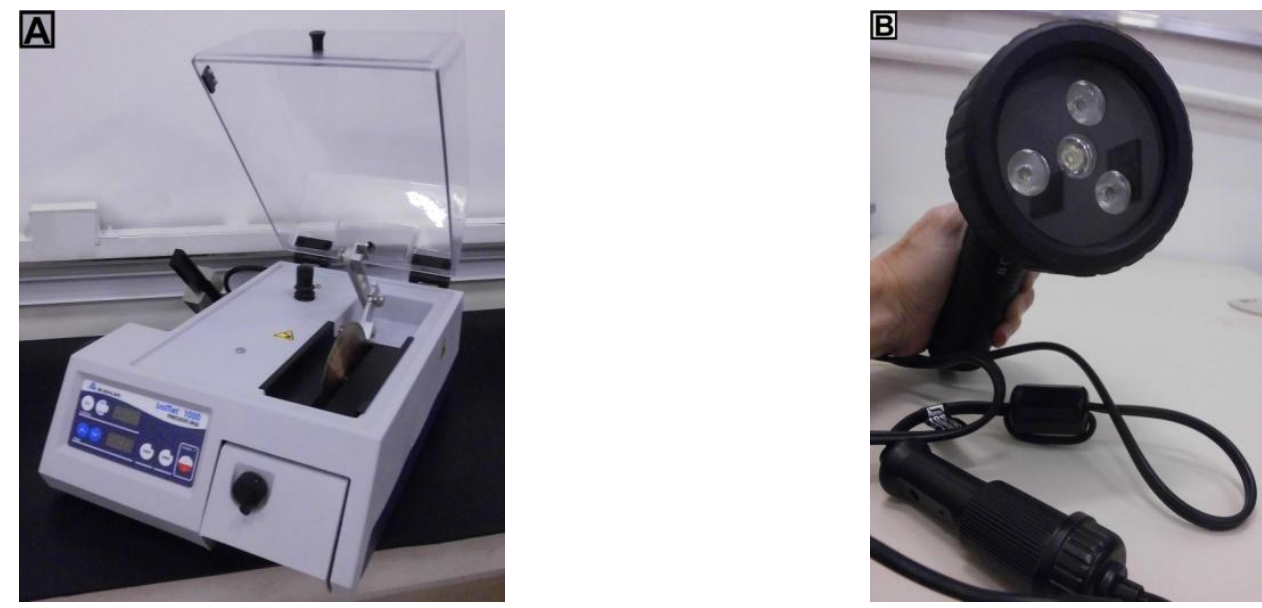

Figura $6_{\mathrm{A}}$ : Cortadeira de precisão com serras de diamante. Figura $6_{\mathrm{B}}$ : Lanterna UV.
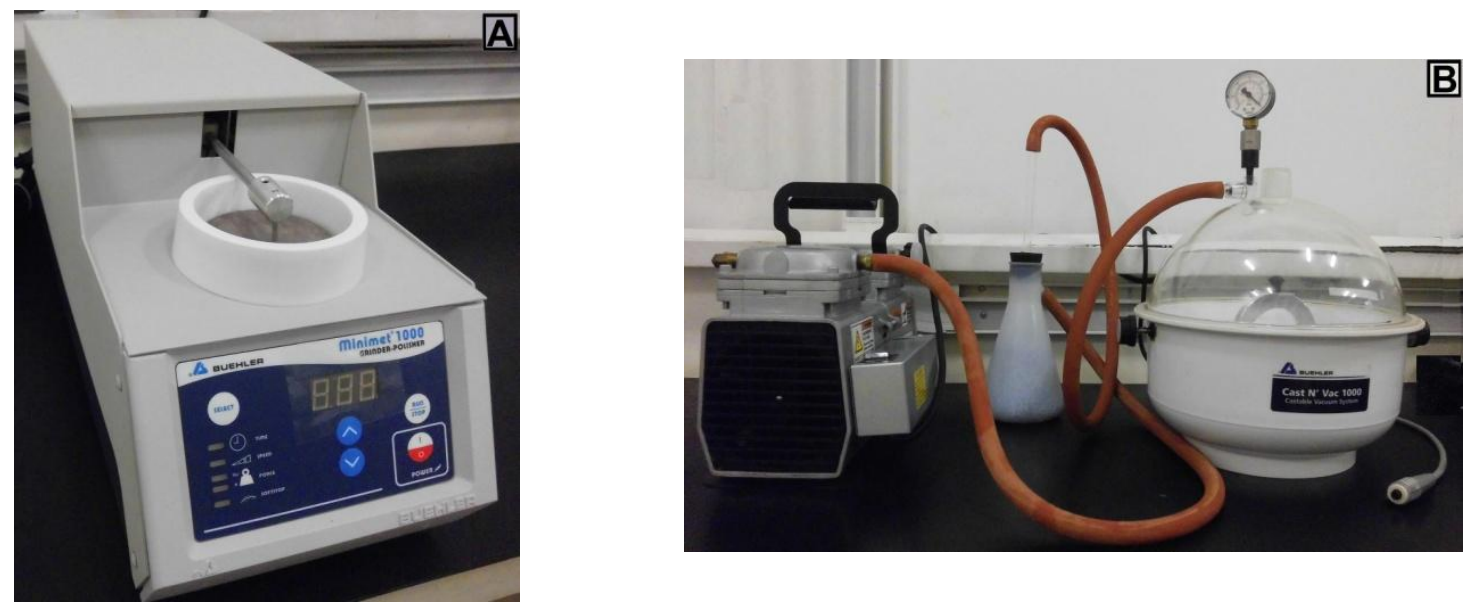

Figura 7A: Politriz. Figura 7B: Câmara de vácuo. 


\section{RESULTADOS}

Serão usados, neste trabalho, os seguintes termos:

Camada pictórica: camada externa do mural, podendo ser de dois tipos: camada carbonática, com ou sem agregados, que recebeu os pigmentos da pintura artística; ou camada de recobrimento posterior à confecção da obra, composta de tinta industrializada.

Camada preparatória: camada de argamassa de cal (sem adição de cimento) aplicada pelo artista para regularização e/ou texturização da parede, com a finalidade de prepará-la para receber a camada pictórica.

Para que se possa registrar melhor a cor das superfícies pictóricas das amostras, foi usada a tabela de cores Rock-Color Chart (ROCK-COLOR CHART COMMITTEE, 1963). 


\subsection{AMOSTRA 01}

\subsubsection{DESCRIÇÃO MASCROSCÓPICA}

A amostra 01 possui superfície rugosa. A camada externa é de cor rosa, mas como houve perda de material, a camada subjacente é parcialmente visível, em porções cinzas e brancas. Na porção esquerda da amostra há marcas do incêndio (Figura 8). Segundo a tabela Rock-Color Chart (ROCK-COLOR CHART COMMITTEE, 1963), a cor que mais se aproxima da cor rosa da superfície desta amostra é a "Moderate orange pink HUE $10 \mathrm{R}$ 7/4".

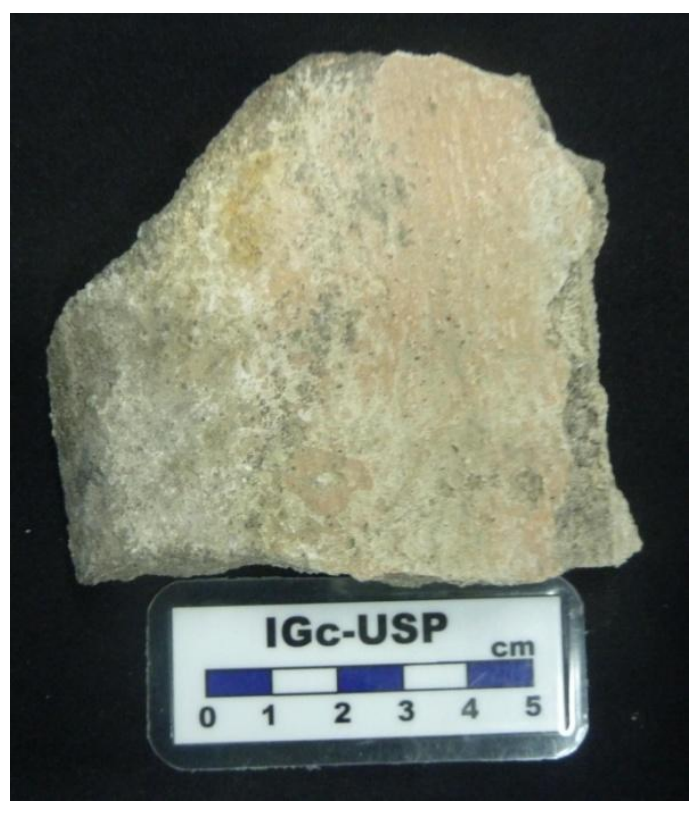

Figura 8: Amostra 01.

No corte estratigráfico da amostra 01 (Figura $9_{A}$ ) é possível distinguir uma camada delgada (camada 'P') por sobre a camada de argamassa (camada 'l'). Este contato está indicado com tracejado na Figura $9_{\mathrm{B}}$. A camada superficial 'P' é submilimétrica $\mathrm{e}$ apresenta cor rosa. A camada 'l' é composta de aglomerante de cor branca e agregados de esfericidade baixa, angulosos e mal selecionados - areia fina a grossa (escala de Wentworth). Não é possível determinar a espessura desta camada pois a quebra da amostra não possibilita ver seu contato com outro material. 

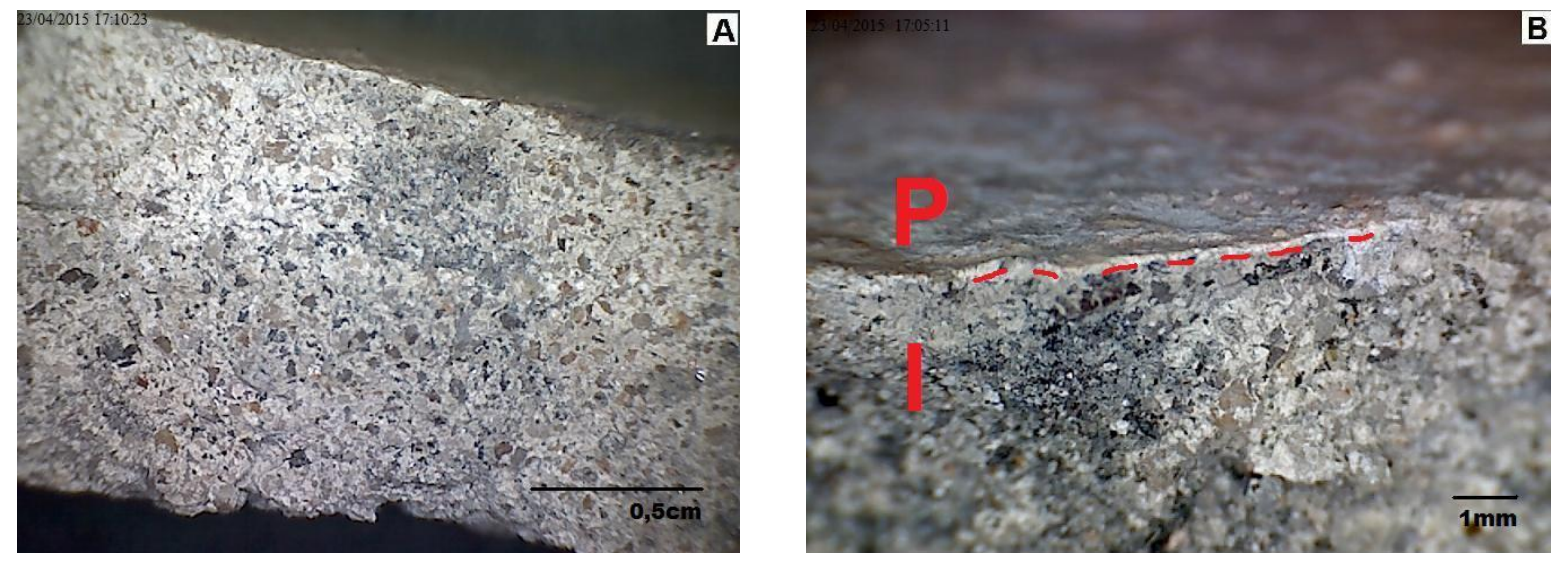

Figura 9: Amostra 01. A: Corte estratigráfico. B: Tracejado indica o contato entre as camadas 'l' e 'P'. 


\subsubsection{DESCRIÇÃO PETROGRÁFICA}

Conforme as Figuras $10_{A}$ e $10_{B}$, a camada ' $P$ ' possui espessura irregular e bastante reduzida - em torno de $200 \mu \mathrm{m}$, composta de material argiloso com aspecto de lama carbonática, e raros grãos minerais muito finos. Em sua superfície há uma região, com espessura ao redor de $20 \mu \mathrm{m}$, podendo chegar a $100 \mu \mathrm{m}$, impregnada de material opaco, desde muito fino até grumos de até $20 \mu \mathrm{m}$. Esta é a camada pictórica desta amostra, a porção impregnada corresponde à região na qual o pigmento aplicado pelo artista penetrou (Figuras 11 e 12). Outros dados que corroboram com esta afirmação encontram-se adiante nos resultados das análises de MEV/EDS e FRX - o artista usou uma mistura de pigmentos vermelho ocre óxido de ferro, contendo resíduos terrosos ricos em Si e Al - e branco de titânio (dióxido de titânio), resultando na cor rosa que a superfície desta amostra apresenta (Figura 8). Nas Figuras $13_{A}$ e $13_{B}$ destaca-se detalhe da região impregnada pelos pigmentos.

A camada ' $l$ ' possui como aglomerante material argiloso com aspecto de lama carbonática e agregados angulosos, de baixa esfericidade, de granulometria principal entre 0,1 e $1 \mathrm{~mm}$, e predomínio de grãos de quartzo, com raros grãos de feldspatos e micas (Figuras $14_{\mathrm{A}}$ e 14 $\mathrm{B}$ ). Esta é aqui interpretada como camada preparatória aplicada pelo artista. 

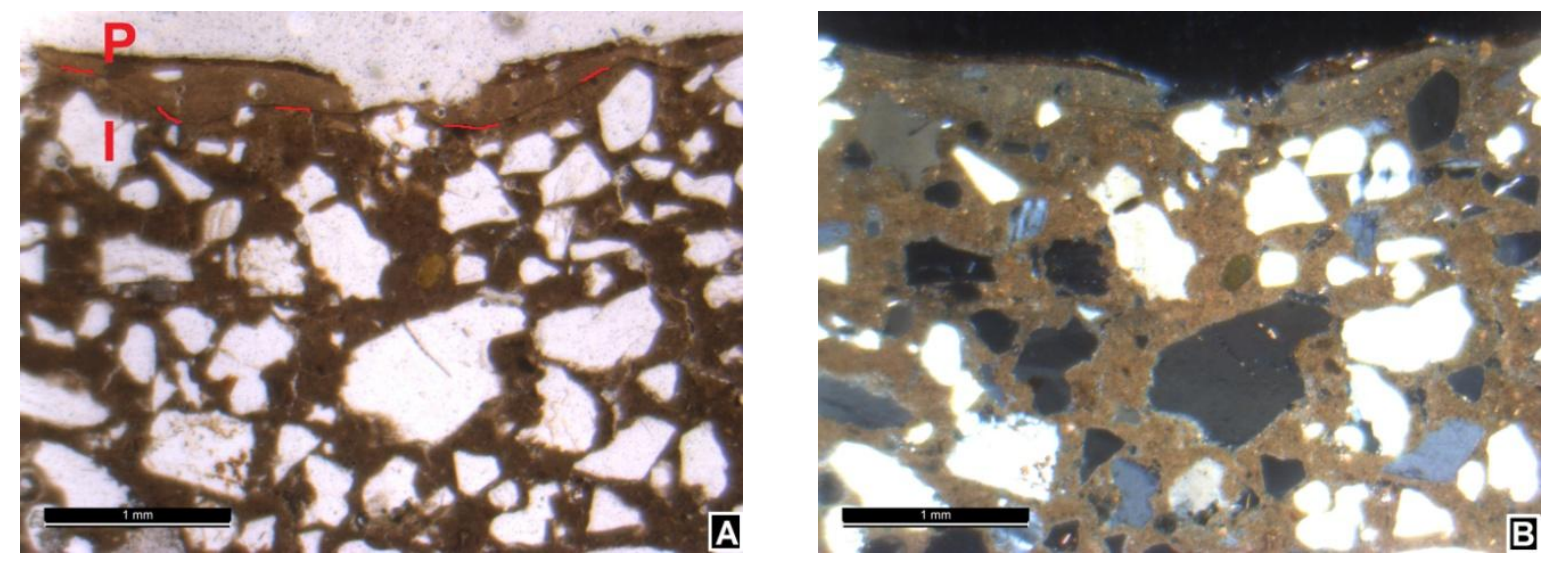

Figura 10: Fotomicrografia da amostra 01 . O tracejado indica o contato entre as camadas 'l' e 'P'. A: Polarizadores paralelos. B: Polarizadores cruzados.

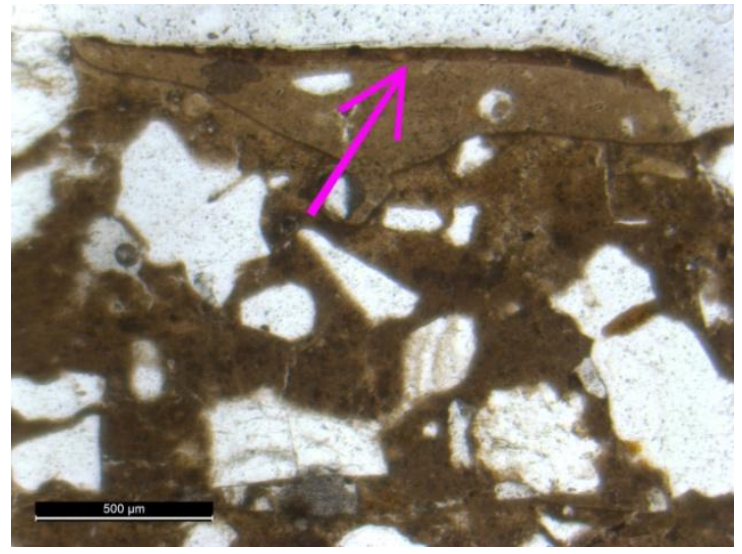

Figura 11: Fotomicrografia da amostra 01. Porção superior da camada ' $P$ ', indicada pela seta, refere-se à região em que o pigmento aplicado pelo artista penetrou na camada pictórica. Polarizadores paralelos.

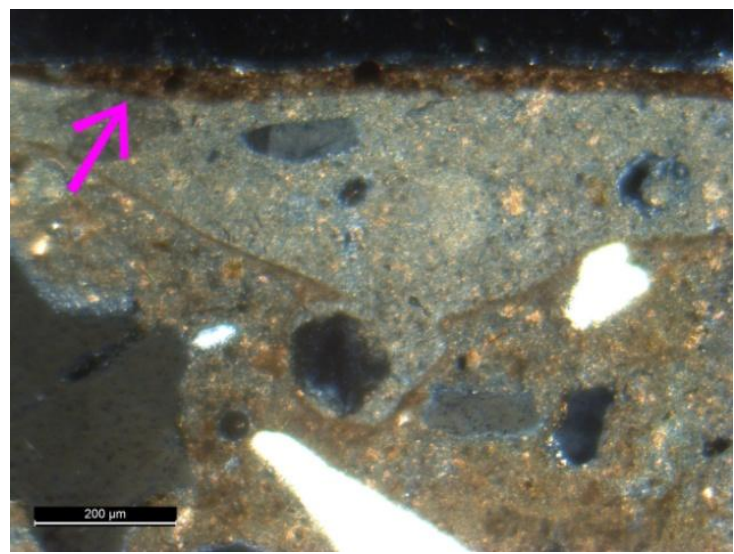

Figura 12: Fotomicrografia da amostra 01. Detalhe da porção superior da camada ' $P$ ', indicada pela seta, refere-se à região em que o pigmento aplicado pelo artista penetrou na camada pictórica. Polarizadores cruzados. 

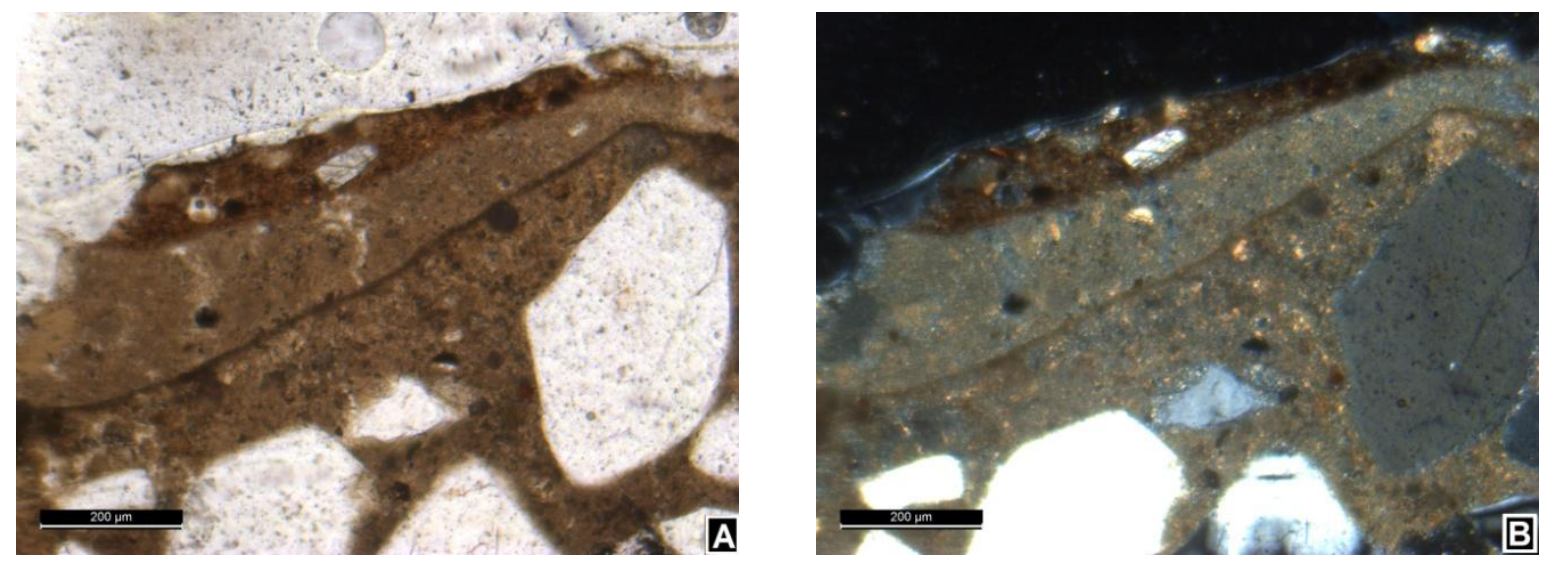

Figura 13: Fotomicrografia da amostra 01. Detalhe da camada 'P' - camada pictórica - com sua superfície impregnada com a mistura de pigmentos aplicados pelo artista. A: Polarizadores paralelos. B: Polarizadores cruzados.
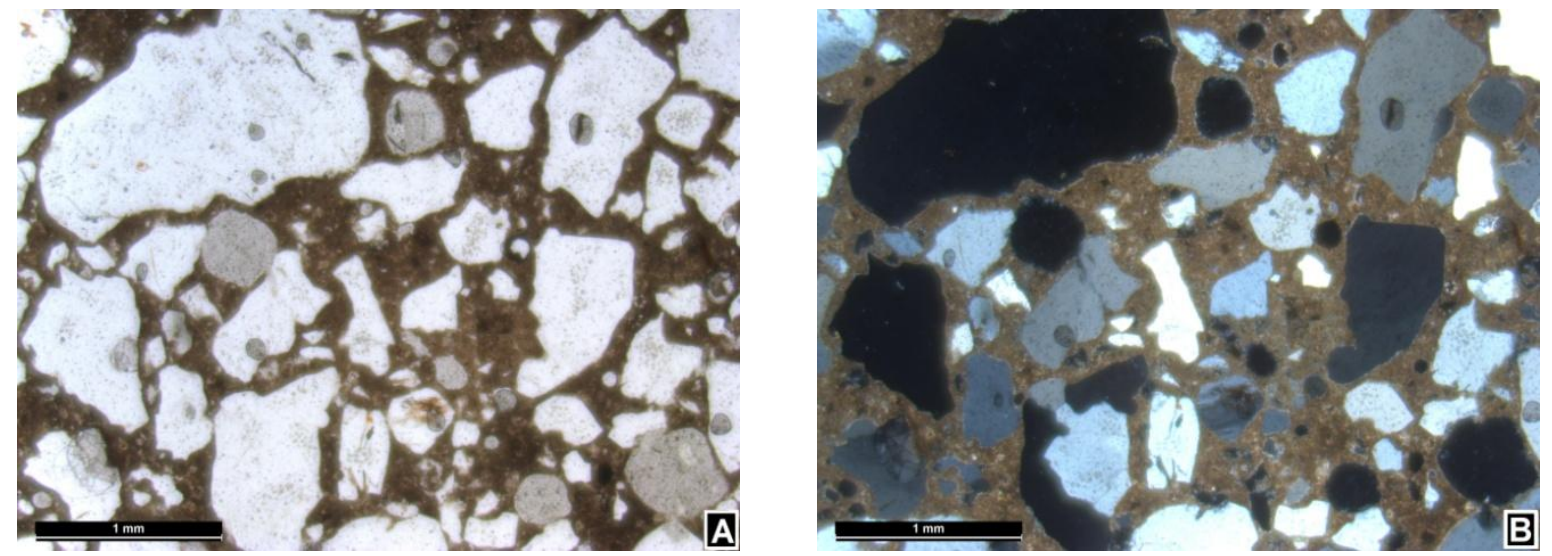

Figura 14: Fotomicrografia da amostra 01. Detalhe da camada 'l'. A: Polarizadores paralelos. B: Polarizadores cruzados. 


\subsubsection{MEV/EDS}

Foram feitos dois tipos de análise em MEV/EDS: análise de fragmentos da superfície das amostras, e análise da estratigrafia das mesmas. Para se obter bons resultados nos mapeamentos de composição química por EDS, a face da amostra a ser analisada deve ser plana. Os fragmentos de superfície apresentaram topografia suficientemente regular, resultando em análises bem sucedidas. Já os fragmentos dos cortes estratigráficos inicialmente foram analisados sem o prévio processo de embutimento, e o material, por ser friável, apresentou topografia demasiadamente irregular e parte das análises não apresentou bons resultados. Para resolver este problema optou-se por embutir os fragmentos em resina, conforme descrito no item materiais e métodos.

\subsection{3a MEV/EDS - CORTE ESTRATIGRÁFICO}

A Figura $15_{A}$ mostra o fragmento, embutido em resina, da amostra 01 . A Figura $15_{B}$ mostra a região da amostra que foi analisada em MEV/EDS.

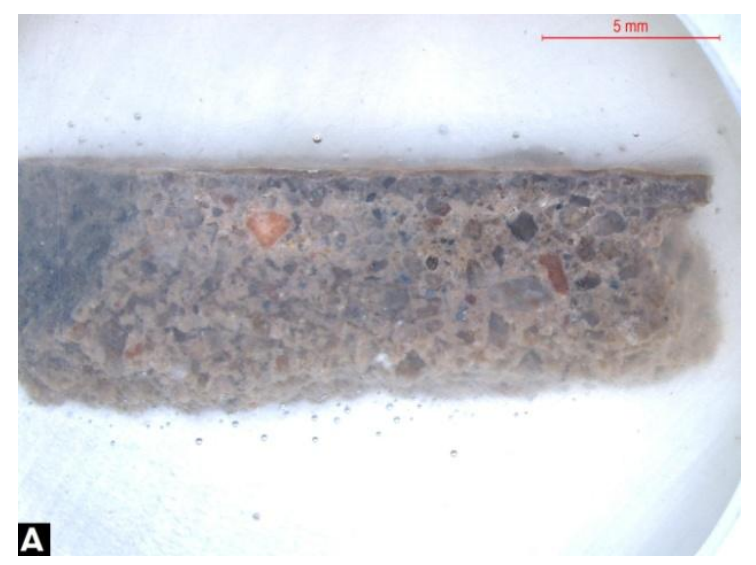

B

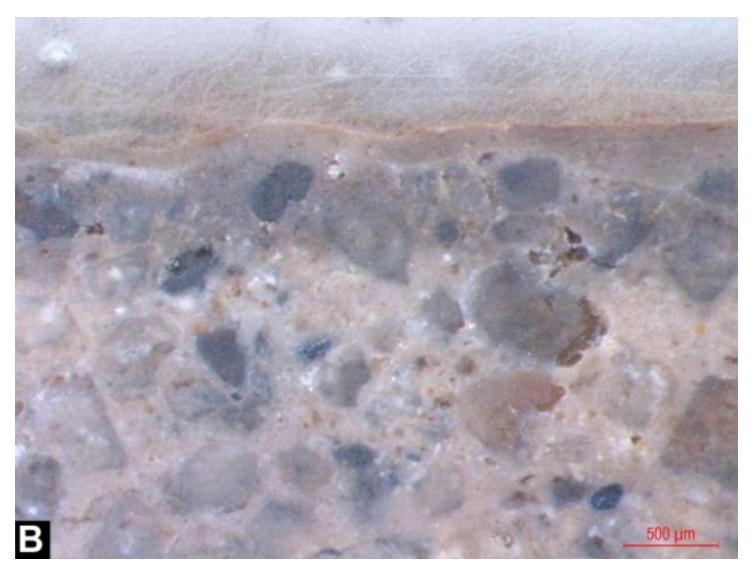

Figura 15 : Fragmento da amostra 01 embutido em resina para ser analisado em MEV/EDS. 15 
A imagem da Figura $16_{\mathrm{A}}$ mostra a primeira área da amostra 01 que foi mapeada para os seguintes elementos: $\mathrm{Ca}, \mathrm{Mg}, \mathrm{O}, \mathrm{Si}, \mathrm{K}, \mathrm{Al}, \mathrm{Fe}, \mathrm{Ti}, \mathrm{S}$ e $\mathrm{P}$. O elemento $\mathrm{P}$ não apresentou distribuição no mapeamento, isso ocorre quando o elemento não está presente ou quando sua quantidade não é significativa, portanto não detectável pelo EDS.

Na Figura $16_{B}$, o contato entre as camadas pictórica 'P' e preparatória 'l' mostra-se como uma película enriquecida em cálcio. Portanto, quando a camada ' $P$ ' foi aplicada, a camada 'l' já estava em processo de carbonatação, logo sua superfície já estava seca ou semisseca.

A Figura $16_{\mathrm{B}}$ mostra a distribuição pervasiva e intensa do elemento $\mathrm{Ca}$ no aglomerante em ambas as camadas, e a Figura 17 $17_{\mathrm{A}}$ mostra concentração menor do elemento $\mathrm{Mg}$, revelando a aplicação de cal mais rica em cálcio como aglomerante.

Os mapeamentos para os elementos $\mathrm{O}, \mathrm{Si}, \mathrm{K}$ e Al (respectivamente Figuras $17_{\mathrm{B}}$, $18_{A}, 18_{B}$ e $19_{A}$ ) confirmam a alta concentração de grãos de quartzo no agregado da camada 'l', em detrimento de feldspatos e outros minerais.

A distribuição do elemento $S$ não é muito intensa, mas está presente (Figura $19_{\mathrm{B}}$ ). Isso se deve a quantidades variáveis de gesso que o artista costumava misturar nas suas argamassas, com a finalidade de obter diferentes efeitos estéticos (Del Lama, 2006). A presença do $S$ na camada superficial desta amostra é confirmada pelos resultados da FRX apresentados adiante (Tabela 1).

As Figuras $20_{\mathrm{A}}$ e $20_{\mathrm{B}}$ revelam que os elementos $\mathrm{Fe}$ e Ti aparecem como agregados em raros grãos do mineral ilmenita. 

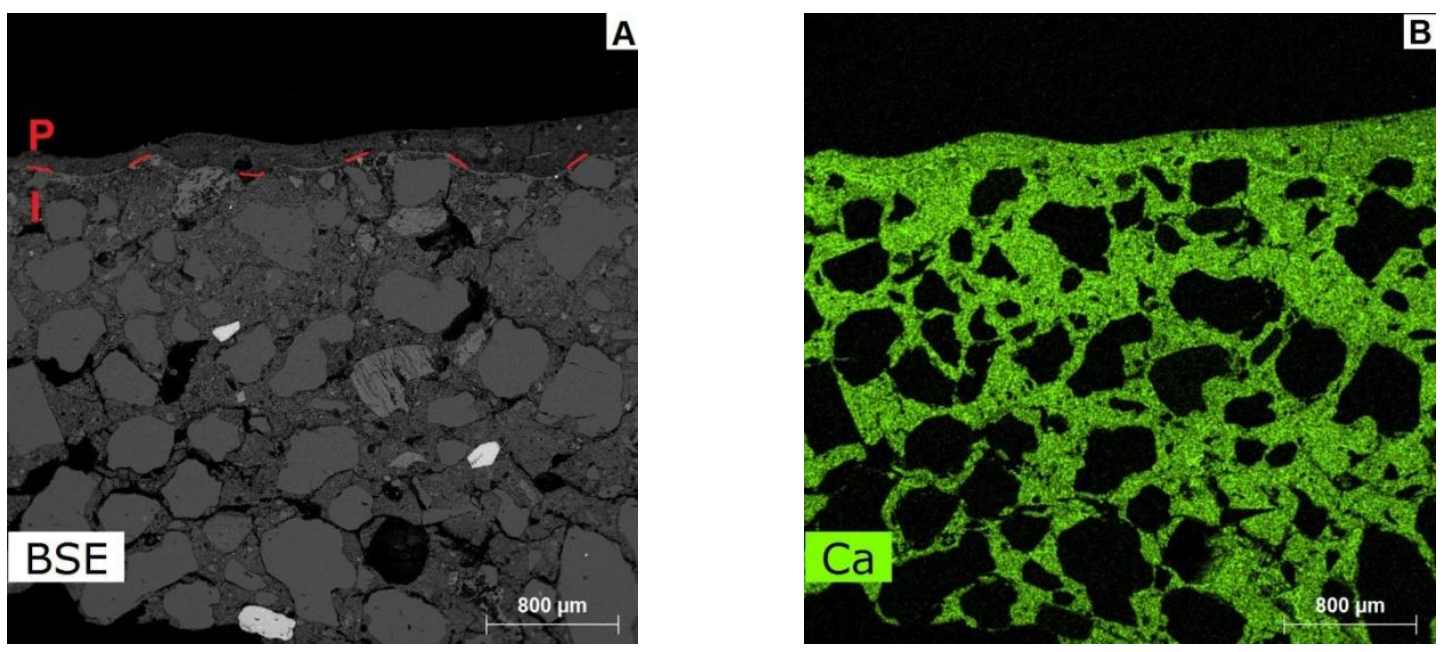

Figura 16A: Primeira área da amostra 01 analisada em MEV. Imagem de elétrons retroespalhados. 16 $\mathrm{B}$ : Mapeamento pelo EDS do elemento Ca na primeira área da amostra 01.
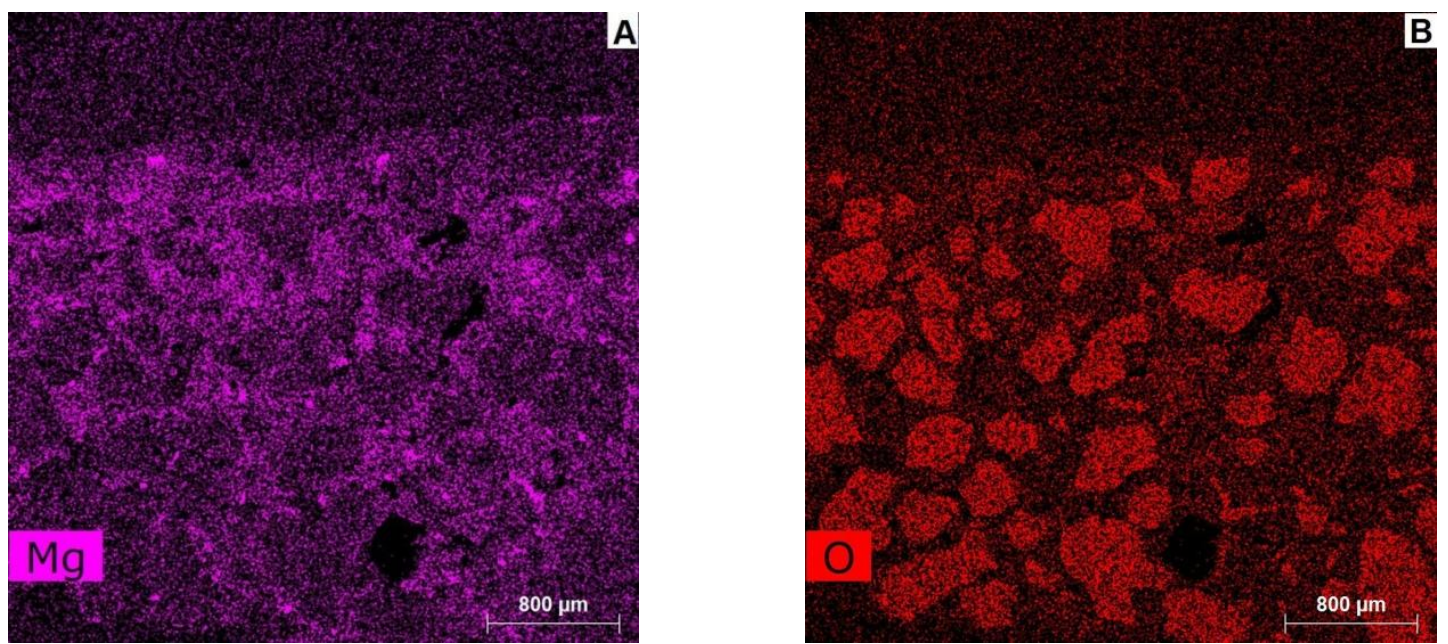

Figura 17: Mapeamentos composicionais por EDS na primeira área analisada da amostra 01. A: Mapeamento do elemento Mg; B: Mapeamento do elemento $\mathrm{O}$.
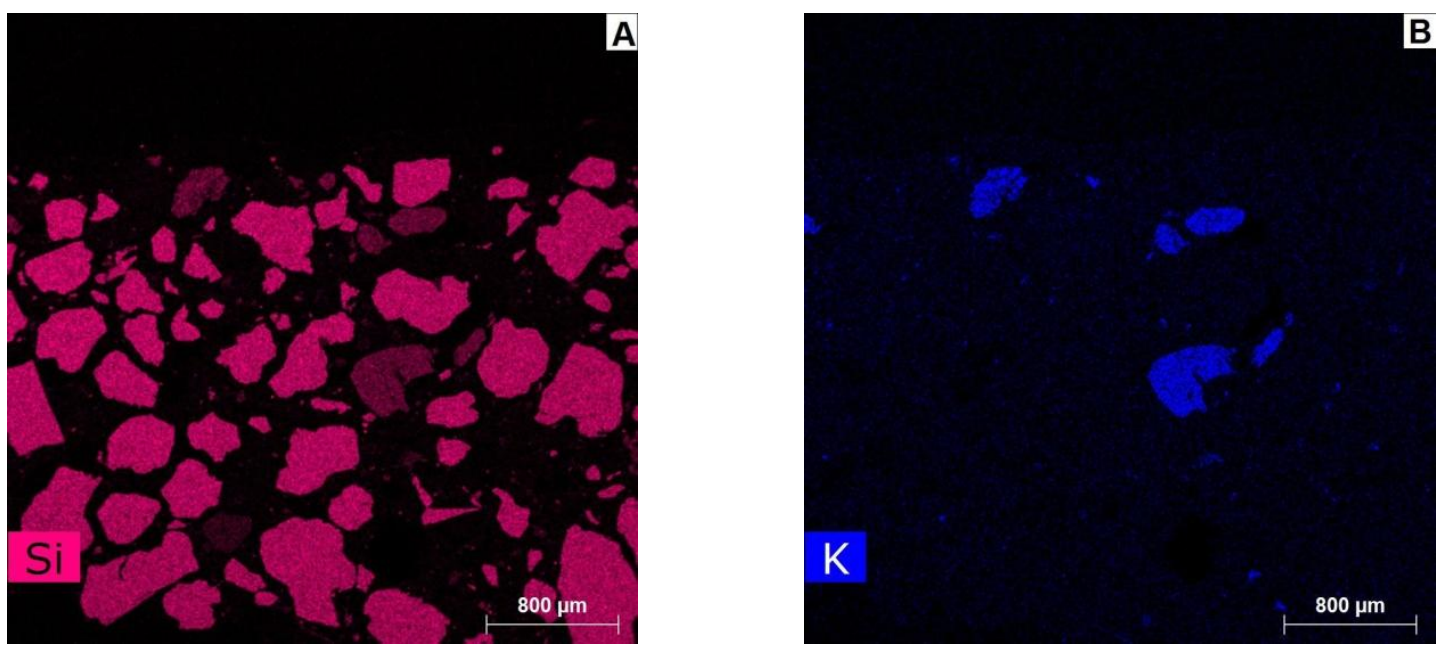

Figura 18: Mapeamentos composicionais por EDS na primeira área analisada da amostra 01. A: Mapeamento do elemento Si; B: Mapeamento do elemento K. 

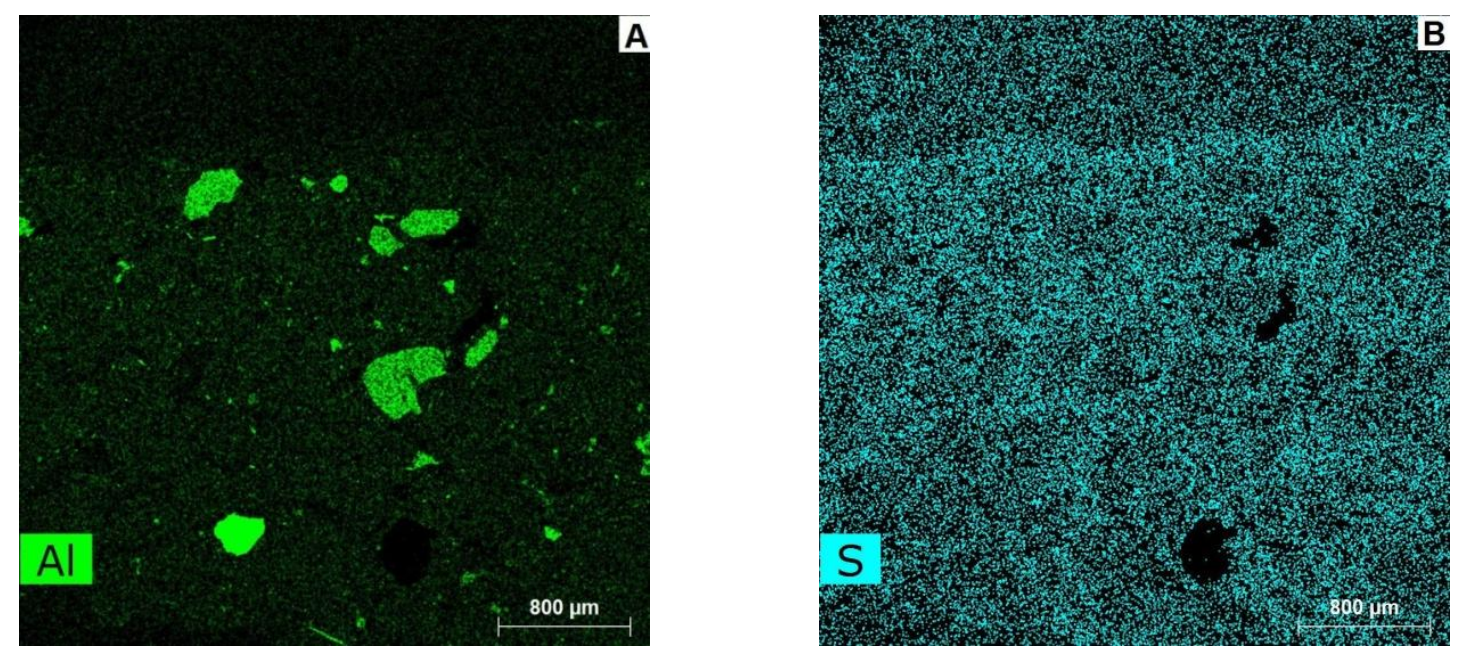

Figura 19: Mapeamentos composicionais por EDS na primeira área analisada da amostra 01. A: Mapeamento do elemento Al; B: Mapeamento do elemento S.
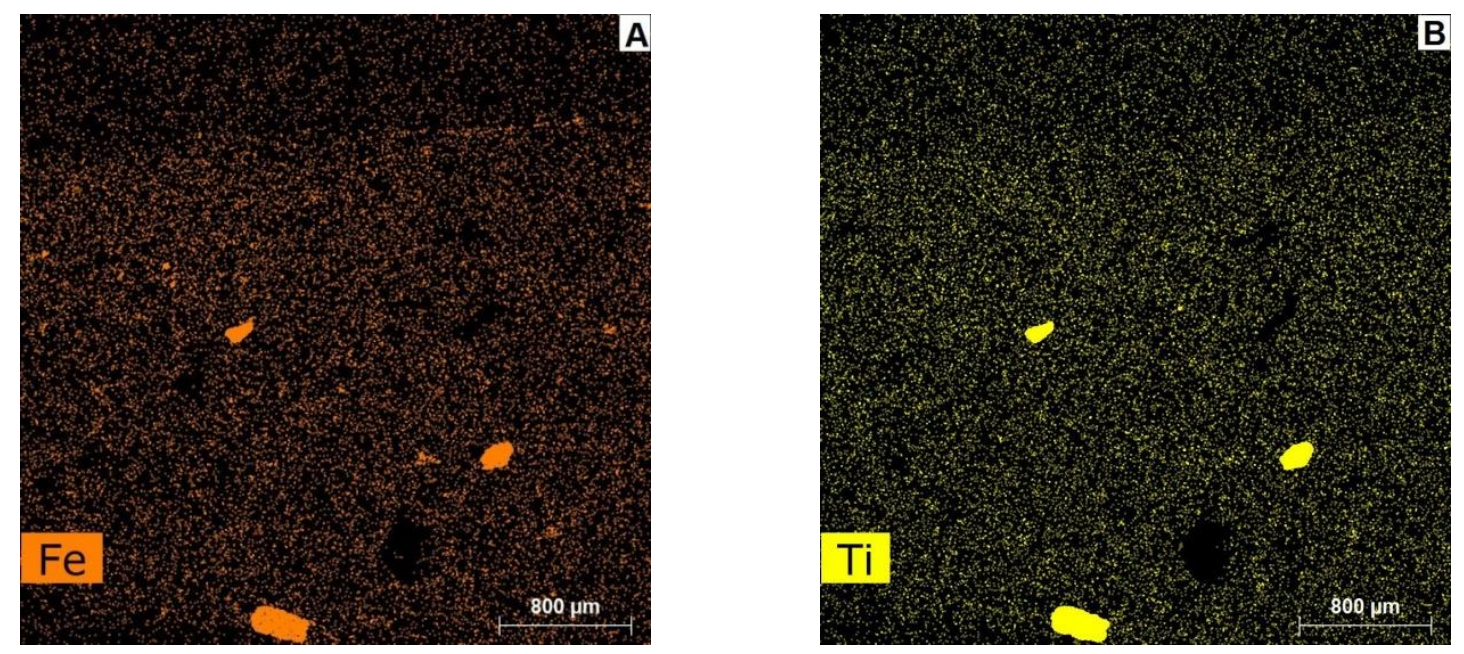

Figura 20: Mapeamentos composicionais por EDS na primeira área analisada da amostra 01. A: Mapeamento do elemento Fe; B: Mapeamento do elemento Ti. 
A segunda área da amostra 01 analisada no MEV/EDS (Figura 21A) é um detalhe da primeira área.

A Figura $21_{\mathrm{B}}$ confirma a película de material rico em cálcio existente no contato entre as camadas.

A camada ' $P$ ', por ser a camada superficial da amostra e por encontrar-se pigmentada, é aqui interpretada como camada pictórica. Micropartículas contendo os elementos $\mathrm{Fe}, \mathrm{Al}$ e em menor quantidade Ti, estão distribuídas ao longo da superfície desta camada (Figuras $22_{\mathrm{A}}, 22_{\mathrm{B}}$ e 23 ). Adiante, na terceira área analisada no MEV/EDS, o elemento Si também aparece nesse contexto (Figura 24 $\mathrm{B}$ ). Por possuir superfície pictórica de cor rosa (Figura 8), a presença destas partículas leva à interpretação de que o artista usou uma mistura de pigmentos: vermelho ocre composto de óxido de Fe que, por ser comumente proveniente de solos, apresenta como impurezas argilas, ricas em Al, Si, entre outros (Casellato et al., 2000; Hradil et al., 2003) - com dióxido de titânio - pigmento de cor branca (Barnett et al., 2006) para chegar na cor rosa. A confirmação da presença destes elementos na superfície desta camada está nos resultados da FRX (Tabela 1). Vale lembrar que Fulvio Pennacchi disse, em entrevista concedida em 1989, que para a confecção de seus afrescos utilizava terras vermelhas brasileiras (Andre, 1989; Wilhelm, 2006). 

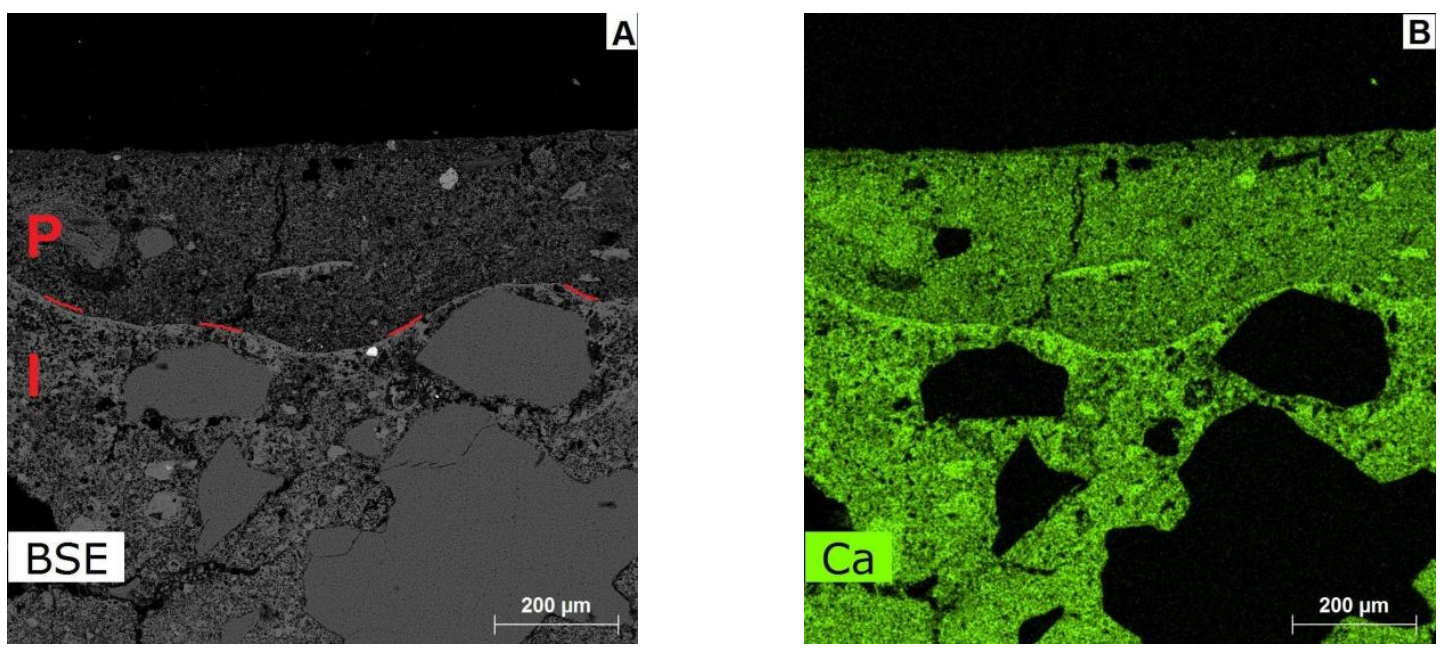

Figura 21 A: Segunda área da amostra 01 analisada em MEV. Imagem de elétrons retroespalhados. $21_{\mathrm{B}}$ : Mapeamento pelo EDS do elemento Ca na segunda área da amostra 01.
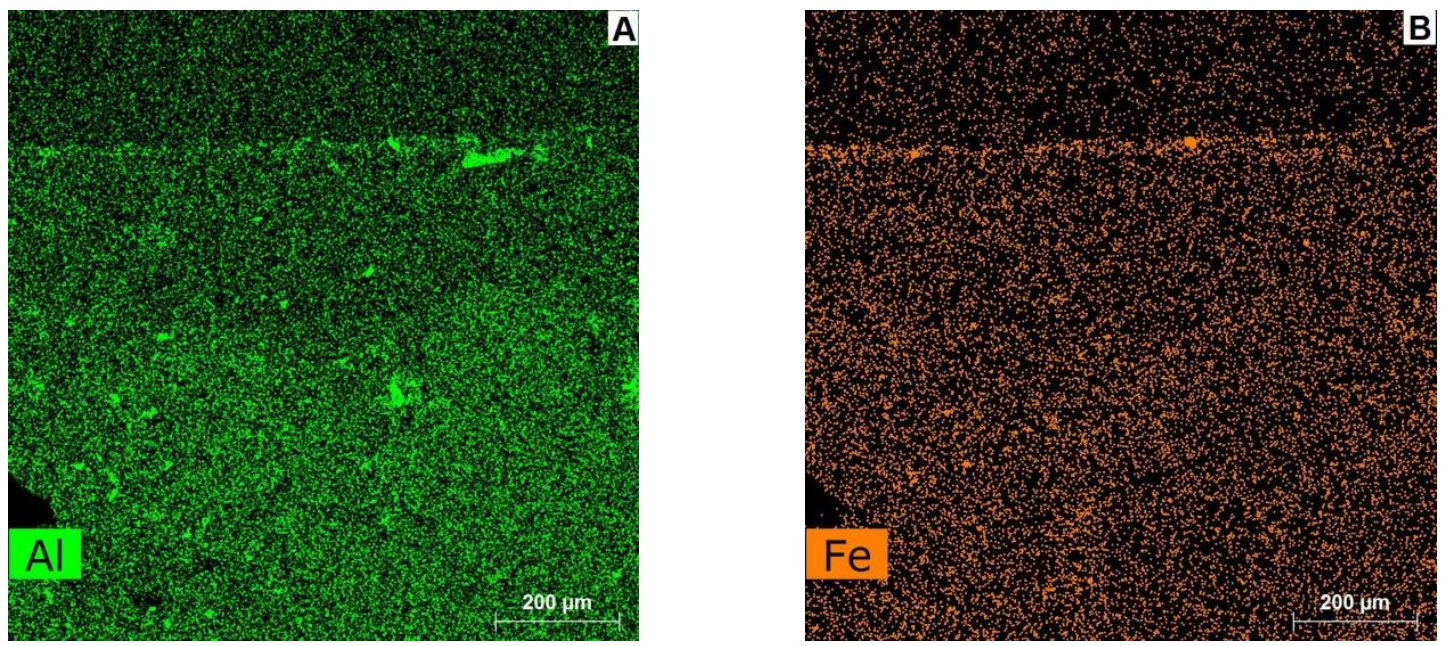

Figura 22: Mapeamentos composicionais por EDS na segunda área analisada da amostra 01. A: Mapeamento do elemento Al; B: Mapeamento do elemento Fe.

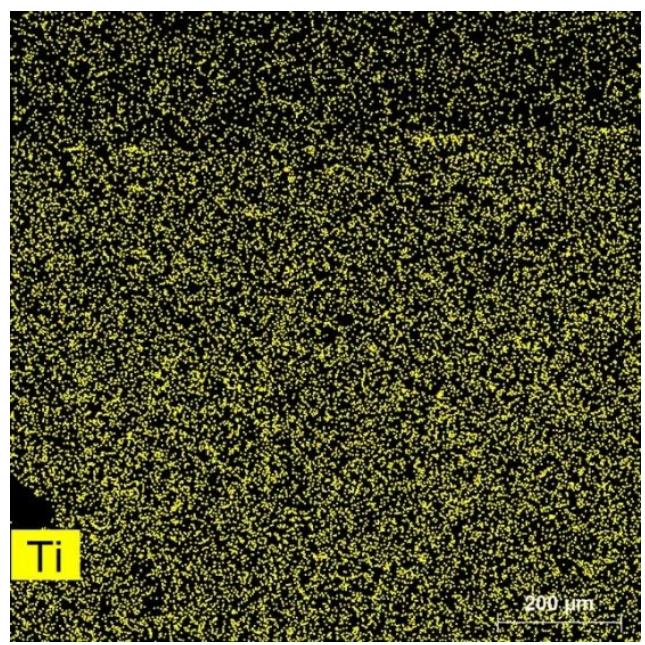

Figura 23: Mapeamento composicional por EDS do elemento Ti, na segunda área analisada da amostra 01. 
A Figura $24_{\mathrm{A}}$ mostra a terceira área da amostra 01 analisada no MEV/EDS, enfocando apenas uma porção superficial da camada ' $P$ ' (camada pictórica). As Figuras $25_{B}$ e $26_{A}$ confirmam a presença de partículas de $\mathrm{Fe}$, e em menor quantidade de $\mathrm{Ti}$, imersas nos primeiros $20 \mu \mathrm{m}$ da camada em questão. Adiante, os resultados de MEV/EDS feitos em fragmentos da superfície da amostra (Figuras $30_{\mathrm{A}}$ e $30_{B}$ ) confirmam a presença destes dois elementos.

Nas Figuras $24_{\mathrm{B}}$ e $25_{\mathrm{A}}$ estão ressaltadas partículas contendo $\mathrm{Si}$ e $\mathrm{Al}$, aqui interpretadas como detritos argilosos presentes no pigmento aplicado pelo artista.

A Figura $26_{B}$ confirma a presença do elemento $S$, ainda que em pequena quantidade, por toda a camada 'P'. 

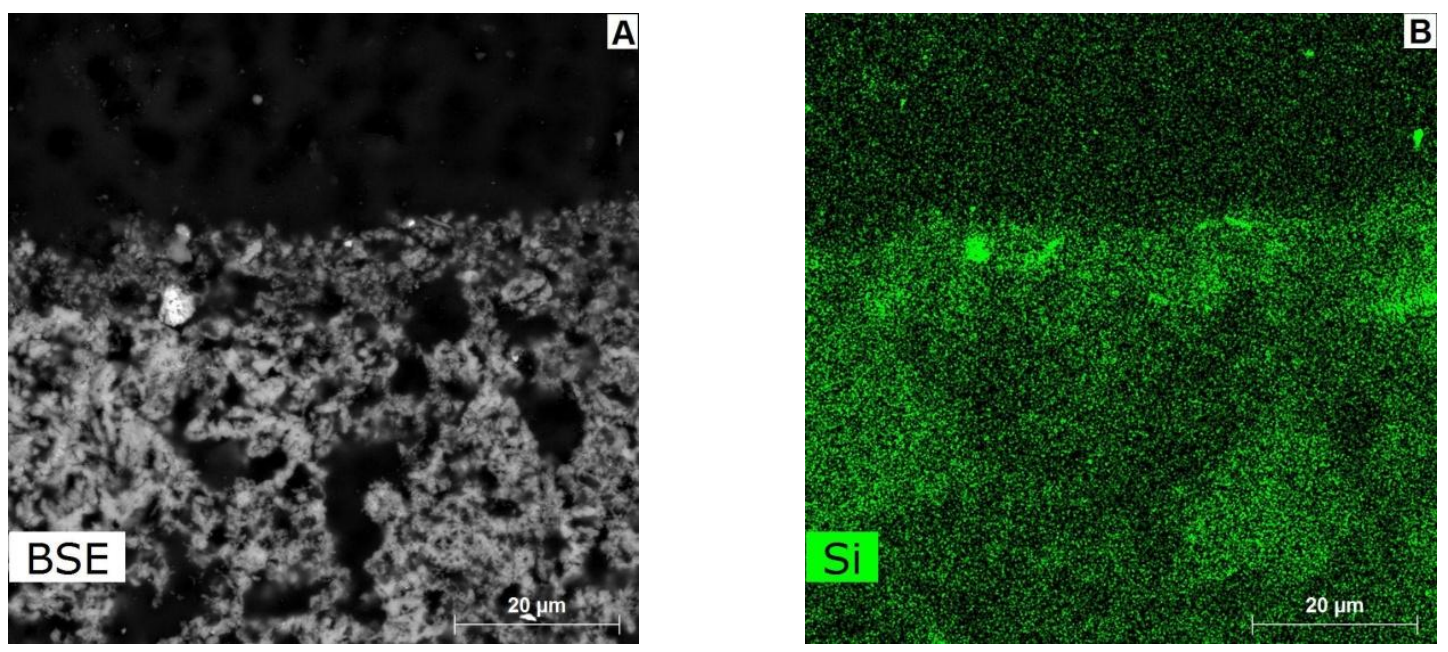

Figura 24A: Terceira área da amostra 01 analisada em MEV. Imagem de elétrons retroespalhados. 24 : Mapeamento pelo EDS do elemento Si na terceira área da amostra 01.
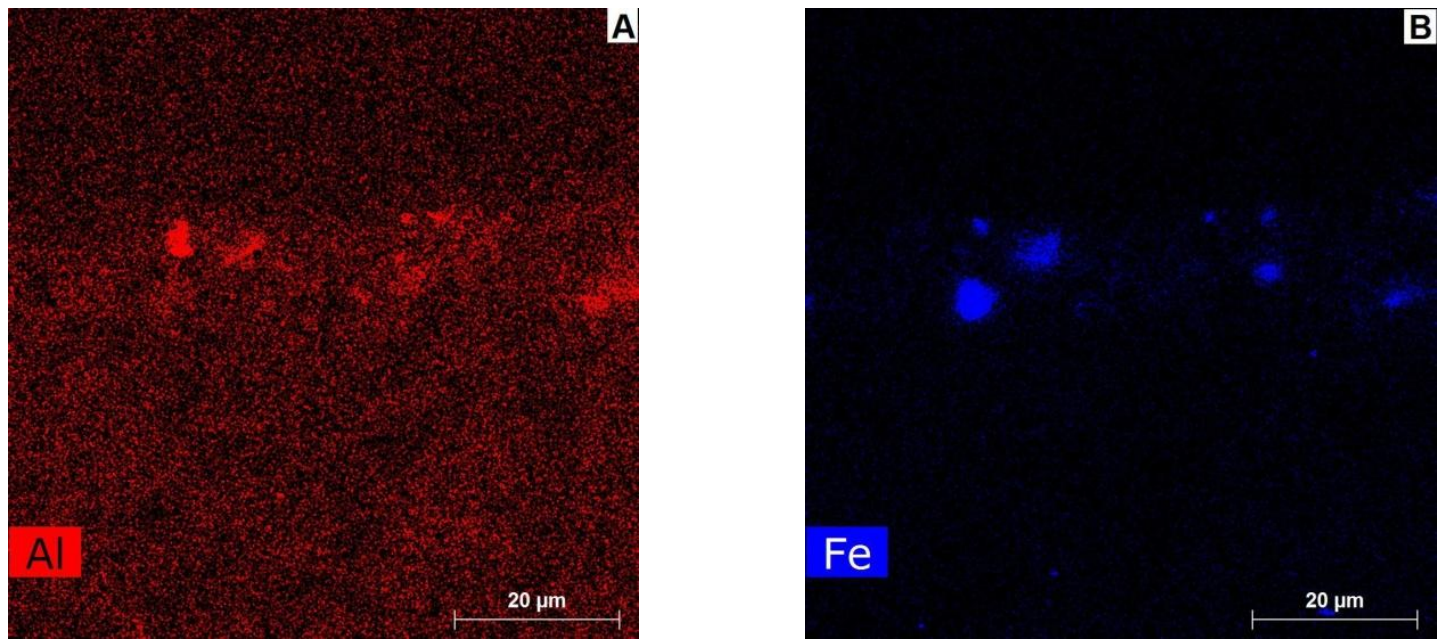

Figura 25: Mapeamentos composicionais por EDS na terceira área analisada da amostra 01. A: Mapeamento do elemento Al; B: Mapeamento do elemento Fe.
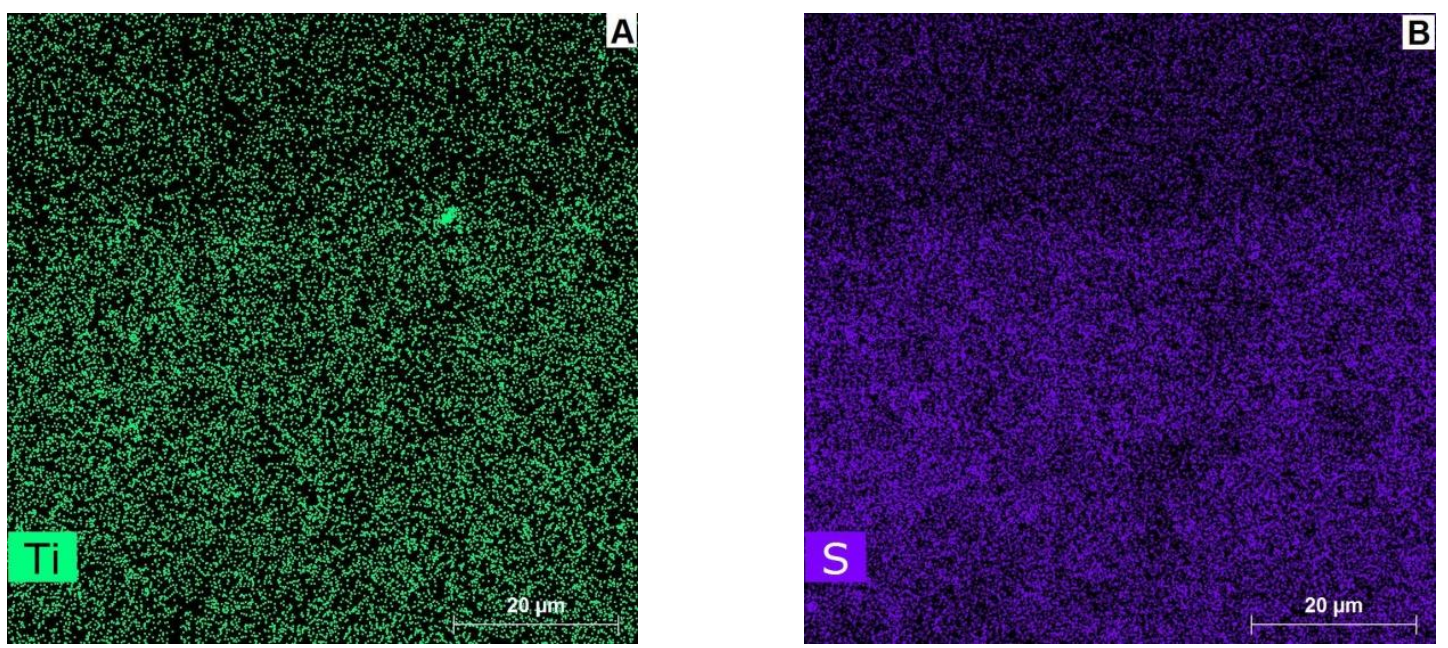

Figura 26: Mapeamentos composicionais por EDS na terceira área analisada da amostra 01. A: Mapeamento do elemento Ti; B: Mapeamento do elemento S. 


\subsection{3b MEV/EDS - SUPERFÍCIE PICTÓRICA}

A Figura 27 mostra o stube - porta amostras utilizado para as análises das superfícies pictóricas - com fragmentos da superfície pictórica da amostra 01.

A Figura 28 mostra a rugosidade da superfície da amostra 01 em imagens de elétrons secundários no MEV.

As Figuras $29_{A}$ e $29_{B}$ mostram a presença de fibras na argamassa. Argamassas reforçadas pela adição de fibras são bastante comuns, e há estudos que indicam que Fulvio Pennacchi lançava mão desta técnica em seus trabalhos (Del Lama, 2006). A imagem da Figura $29_{A}$ foi captada utilizando elétrons secundários, onde é realçada a morfologia do material. Nela são claramente visíveis as fibras, que possuem diâmetros menores que $1 \mu \mathrm{m}$. A imagem da Figura $29_{B}$ foi captada usando os elétrons retroespalhados, configuração esta que diferencia através de claros e escuros os materiais conforme os elementos químicos de suas composições: elementos mais pesados aparecem mais claros, elementos mais leves aparecem mais escuros. Como as fibras tornaram-se bastante escuras nesta imagem, concluise que são fibras orgânicas, compostas de elementos leves.

As Figuras $30_{\mathrm{A}}$ e $30_{\mathrm{B}}$ confirmam a presença de partículas contendo os elementos $\mathrm{Fe}$ e Ti na superfície da amostra 01 , interpretados como componentes dos pigmentos vermelho e branco, que misturados dão a tonalidade cor de rosa desta camada pictórica.

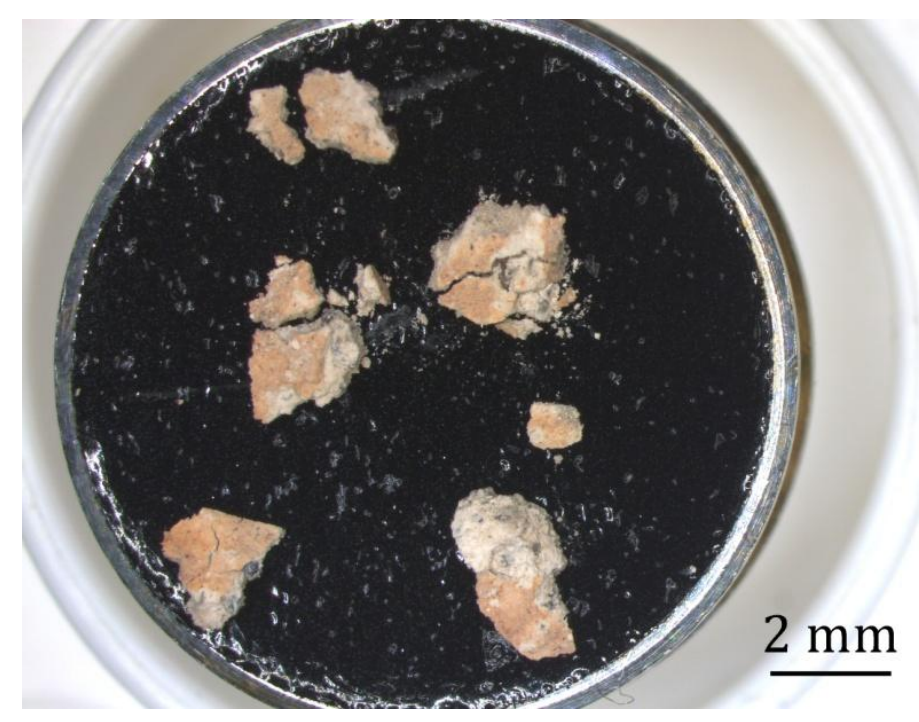

Figura 27: Stube (porta amostras), com fragmentos da superfície da amostra 01. 


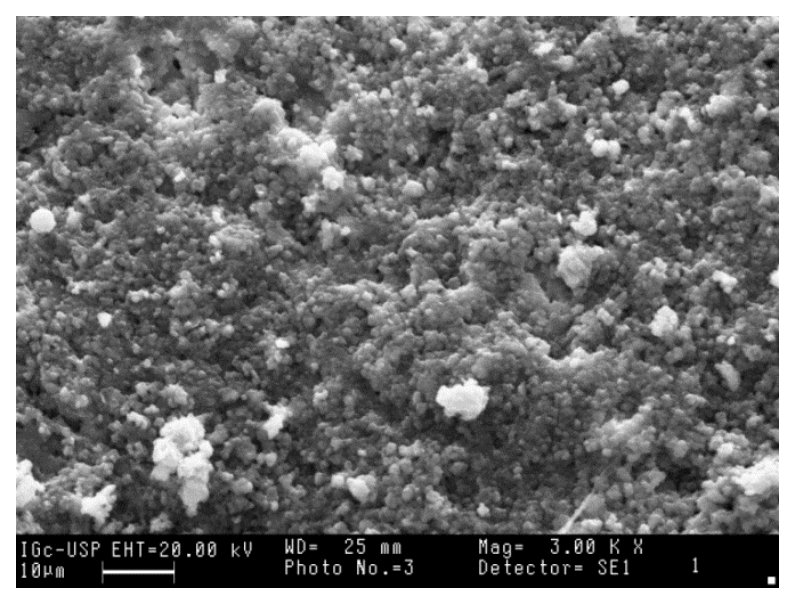

Figura 28: Superfície rugosa da amostra 01. Imagem de elétrons secundários.
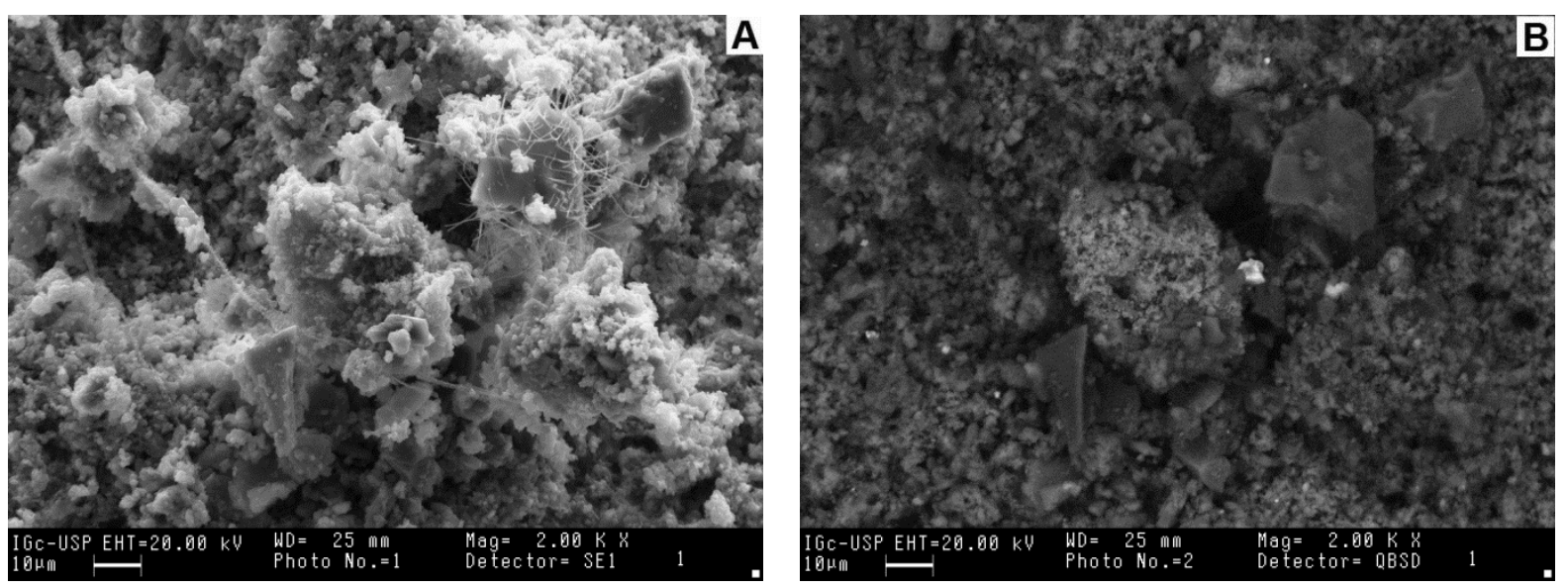

Figura 29: Superfície da amostra 01 sob MEV. A: imagem de elétrons secundários, onde são visíveis fibras. B: imagens de elétrons retroespalhados, onde as mesmas fibras pouco aparecem, consequência do baixo número atômico dos elementos que as compõem.
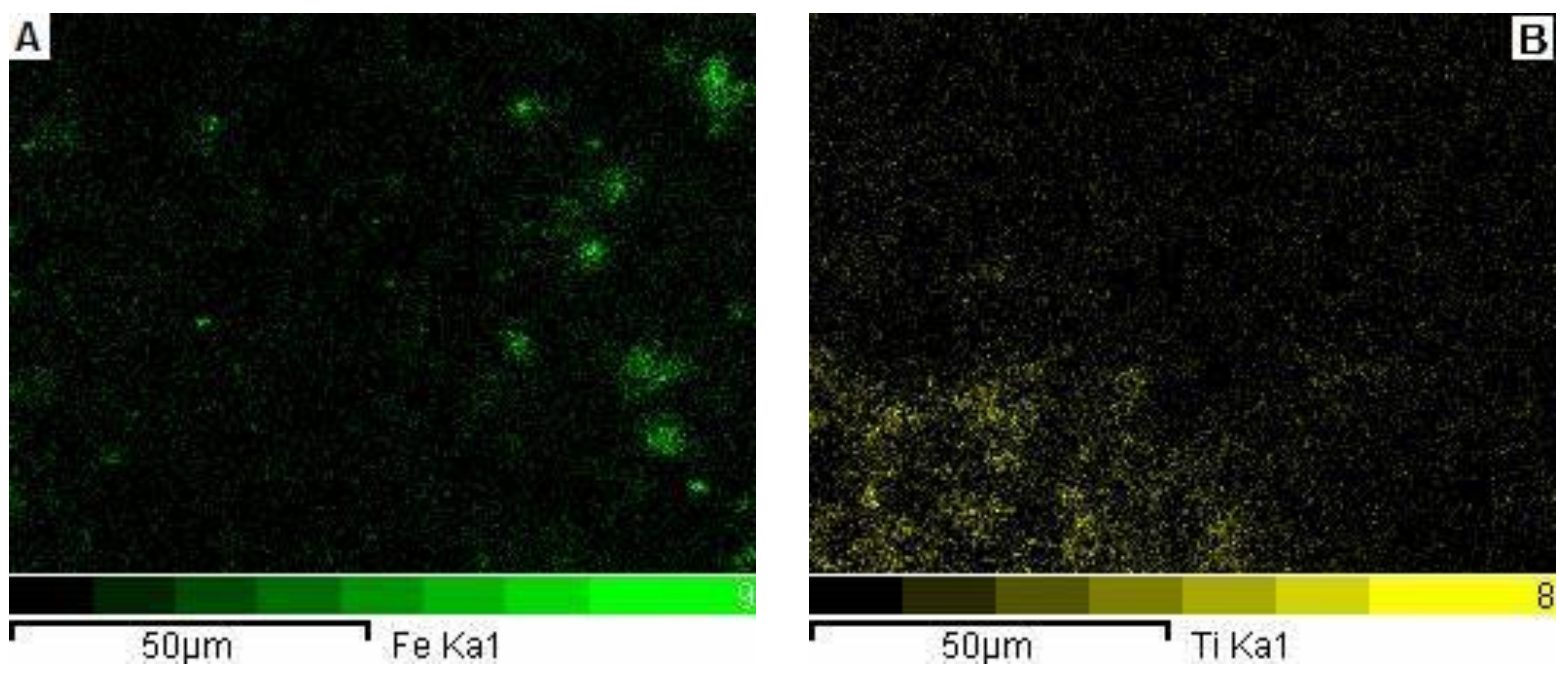

Figura 30: Mapeamentos composicionais feitos com EDS na superfície da amostra 01, na área que aparece na Figura 28. A: Mapeamento do elemento Fe; B: Mapeamento do elemento $\mathrm{Ti}$. 


\subsubsection{FLUORESCÊNCIA DE RAIOS X}

A Tabela 1 mostra os dados da análise química semiquantitativa realizada em espectrômetro de Fluorescência de Raios $X$ através de varredura da superfície de cada uma das amostras. Em vermelho estão destacados os elementos presentes em quantidades significativas na amostra 01. Essas quantidades estão de acordo com os resultados dos mapeamentos composicionais feitos no EDS apresentados anteriormente. $\mathrm{Ca}, \mathrm{Mg}$ e $\mathrm{S}$ correspondem aos principais componentes da argamassa utilizada, enquanto $\mathrm{Fe}, \mathrm{Al}, \mathrm{Si}$ e Ti aos elementos presentes nos pigmentos aplicados.

Tabela 1: Dados semiquantitativos (\%) de espectrometria de fluorescência de raios $X$ de varredura superficial, de todas as amostras para comparação.

\begin{tabular}{|c|c|c|c|c|c|}
\hline AMOSTRA & 01 & 02 & 03 & 04 & 05 \\
\hline Sum sem nor & 75,7 & 88,8 & 67,3 & 82,7 & 66,4 \\
\hline & & & & & \\
\hline $\mathrm{Na}_{2} \mathrm{O}$ & 0,14 & 0,096 & 0,111 & 0,073 & 0,118 \\
\hline $\mathrm{MgO}$ & 5,177 & 4,533 & 47,342 & 4,902 & 9,187 \\
\hline $\mathrm{Al}_{2} \mathrm{O}_{3}$ & 3,662 & 4,341 & 3,478 & 6,188 & 6,812 \\
\hline $\mathrm{SiO}_{2}$ & 7,908 & 7,484 & 4,827 & 11,623 & 17,706 \\
\hline $\mathrm{P}_{2} \mathrm{O}_{5}$ & 0,094 & 0,291 & 0,091 & 0,184 & 0,263 \\
\hline $\mathrm{SO}_{3}$ & 5,834 & 1,179 & 0,517 & 0,828 & 2,105 \\
\hline $\mathrm{Cl}$ & 0,39 & 0,265 & 0,228 & 0,301 & 0,299 \\
\hline $\mathrm{K}_{2} \mathrm{O}$ & 0,31 & 0,419 & 0,208 & 1,16 & 0,541 \\
\hline $\mathrm{CaO}$ & 70,313 & 46,736 & 40,688 & 43,212 & 59,214 \\
\hline $\mathrm{TiO}_{2}$ & 2,614 & 33,64 & 0,777 & 30,615 & \\
\hline $\mathrm{Cr}$ & 0,013 & 0,018 & 0,012 & 0,026 & 0,019 \\
\hline $\mathrm{MnO}$ & 0,078 & 0,035 & 0,044 & 0,007 & \\
\hline $\mathrm{Fe}_{2} \mathrm{O}_{3}$ & 3,228 & 0,638 & 1,335 & 0,482 & 2,43 \\
\hline $\mathrm{Ni}$ & 0,004 & 0,005 & 0,007 & 0,005 & 0,006 \\
\hline $\mathrm{Cu}$ & 0,018 & 0,018 & 0,037 & 0,01 & 0,022 \\
\hline $\mathrm{Zn}$ & 0,037 & 0,076 & 0,091 & 0,023 & 0,138 \\
\hline $\mathrm{Rb}$ & 0,005 & 0,007 & 0,009 & 0,007 & 0,006 \\
\hline $\mathrm{Sr}$ & 0,105 & 0,089 & 0,021 & 0,043 & 0,059 \\
\hline $\mathrm{Y}$ & 0,003 & 0,002 & 0,004 & 0,002 & 0,002 \\
\hline $\mathrm{Zr}$ & 0,033 & 0,031 & 0,038 & 0,019 & 0,027 \\
\hline $\mathrm{Ba}$ & 0,031 & 0,07 & 0,122 & 0,053 & 0,104 \\
\hline $\mathrm{Pb}$ & 0,004 & 0,019 & 0,011 & 0,011 & 0,015 \\
\hline $\mathrm{Br}$ & & & & & 0,002 \\
\hline $\mathrm{Ce}$ & & & & & 0,102 \\
\hline Co & & & & & 0,138 \\
\hline $\mathrm{F}$ & & & & 0,219 & 0,289 \\
\hline $\mathrm{Ga}$ & & 0,002 & & & \\
\hline $\mathrm{Mn}$ & & & & & 0,097 \\
\hline $\mathrm{Nb}$ & & 0,007 & & 0,008 & \\
\hline $\mathrm{Ti}$ & & & & & 0,298 \\
\hline
\end{tabular}




\subsubsection{LANTERNA UV}

A verificação da existência ou não de fluorescência sob lanterna UV neste trabalho não pretende ser diagnóstica, mas sim complementar. O Laboratório de Análises em Herança Cultural do Instituto de Geociências da Universidade de São Paulo dispõe deste aparelho, que é de baixo custo de aplicação, e fácil manuseio.

As imagens foram feitas com câmera fotográfica digital comum (especificações no item materiais e métodos).

Como se pode ver na Figura $31_{A}$, e usando a Figura $31_{B}$ para comparação, a superfície da amostra 01 quando recebe radiação UV apresenta diferentes respostas em função das diferentes camadas expostas, pois houve perda parcial dos materiais. Os locais da superfície onde a camada pictórica contendo o pigmento cor de rosa estão preservados permanecem cor de rosa, evidenciando a não emissão de fluorescência (sob UV $365 \mathrm{~nm}$ ), característica tanto do pigmento vermelho ocre (Stuart, 2007), quanto do branco de titânio (Cosentino, 2014).
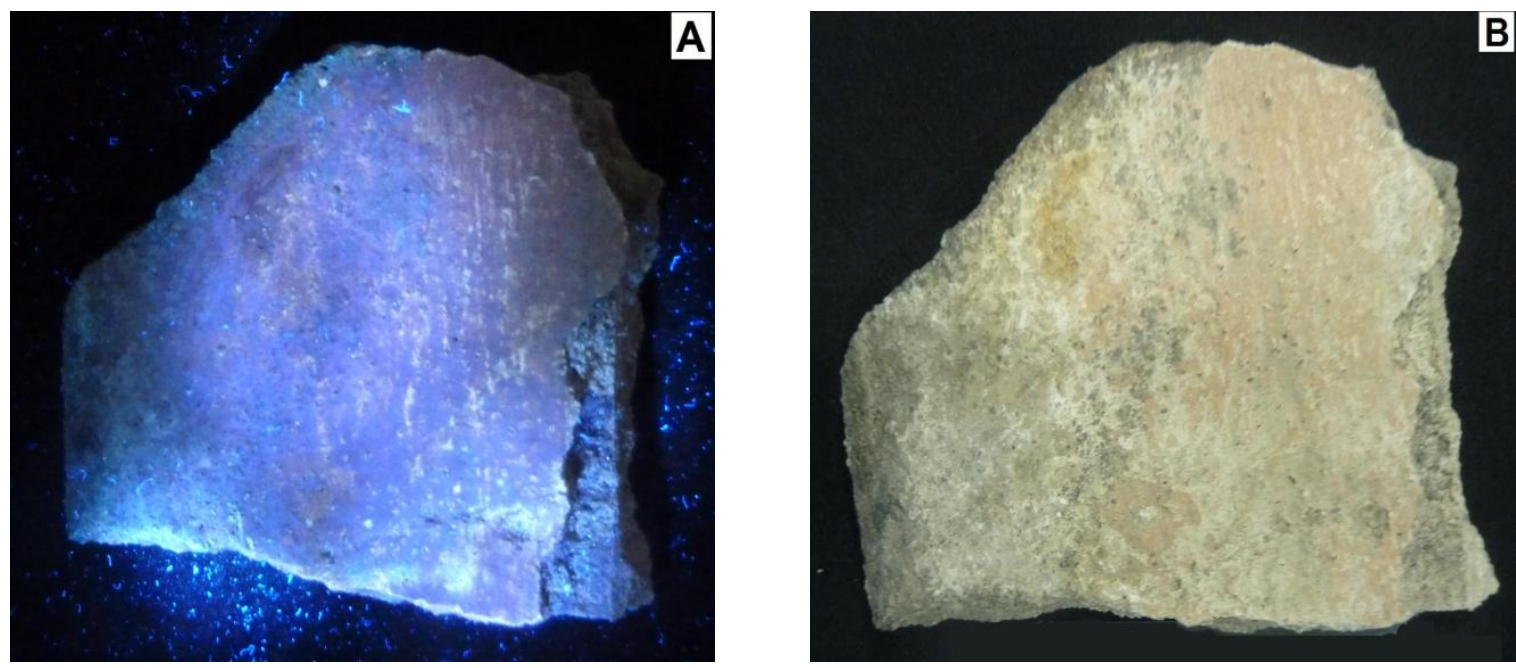

Figura 31 $\mathrm{A}$ : Amostra 01 iluminada por lanterna UV; 31 $\mathrm{B}$ : Amostra 01 sob iluminação ambiente para comparação. 


\subsubsection{CONCLUSÕES SOBRE A AMOSTRA 01}

A camada ' $P$ ' é a camada externa e pigmentada desta amostra, portanto trata-se de camada pictórica. Neste trecho da obra, o artista não utilizou a técnica tradicional do afresco - também chamada de buon fresco, onde os pigmentos são aplicados diretamente sobre a camada de argamassa enquanto ainda se encontra úmida. Sobre camada de argamassa cuja superfície já se encontrava seca ou semisseca (camada 'l'), foi aplicada uma demão de cal, resultando numa camada bastante delgada (camada 'P'). Para chegar na cor rosa, presente na superfície desta, os mapeamentos elementares levam à interpretação de que o artista usou uma mistura dos pigmentos ocre vermelho e branco de titânio.

A técnica de pintura chamada de mezzo fresco é descrita na literatura como a aplicação de água de cal já misturada com os pigmentos, sobre a camada de argamassa em adiantado estado de carbonatação (Cennini, 1398; Tirello, 2001; Tirello, 2006; Del Lama et al., 2009). No caso da amostra 01, as partículas de pigmento estão imersas apenas na superfície da camada 'P' (nos $20 \mu \mathrm{m}$ superficiais aproximadamente), levando a crer que os pigmentos não estavam misturados na cal que formou a camada 'P', e sim foram aplicados sobre a camada 'P' ainda úmida, revelando uma variação da técnica do mezzo fresco.

Ratificando estas observações, WILHELM (2006) destaca que Fulvio Pennacchi costumava mesclar a técnica do buon fresco com a do mezzo fresco.

Neste contexto, a camada 'l' pode ser interpretada como camada preparatória aplicada pelo artista, tanto por ser a camada subjacente à camada pictórica, quanto por sua composição: argamassa de cal. Este trabalho está levando em consideração que as argamassas de acabamento comumente aplicadas pelos empreiteiros de construção civil, desde meados do século XX, apresentam aglomerante contendo cimento Portland (Margalha, 2011; http://www.abcp.org.br/cms/basico-sobrecimento/historia/uma-breve-historia-do-cimento-portland/); enquanto que a literatura registra o uso de aglomerantes de cal e/ou gesso por artistas afresquistas (Cennini, 1398; Mayer, 2002).

A mistura de quantidades variáveis de gesso, evidenciada pela presença do elemento S, também era de uso comum do artista (Del Lama, 2006). 


\subsection{AMOSTRA 02}

\subsubsection{DESCRIÇÃO MACROSCÓPICA}

A amostra número 02 apresenta camada superficial lisa, acinzentada, sendo visível uma camada branca logo abaixo, nos locais onde houve perda da camada superficial, e porções das argamassas mais profundas onde a perda de material foi mais aguda (Figura 32).

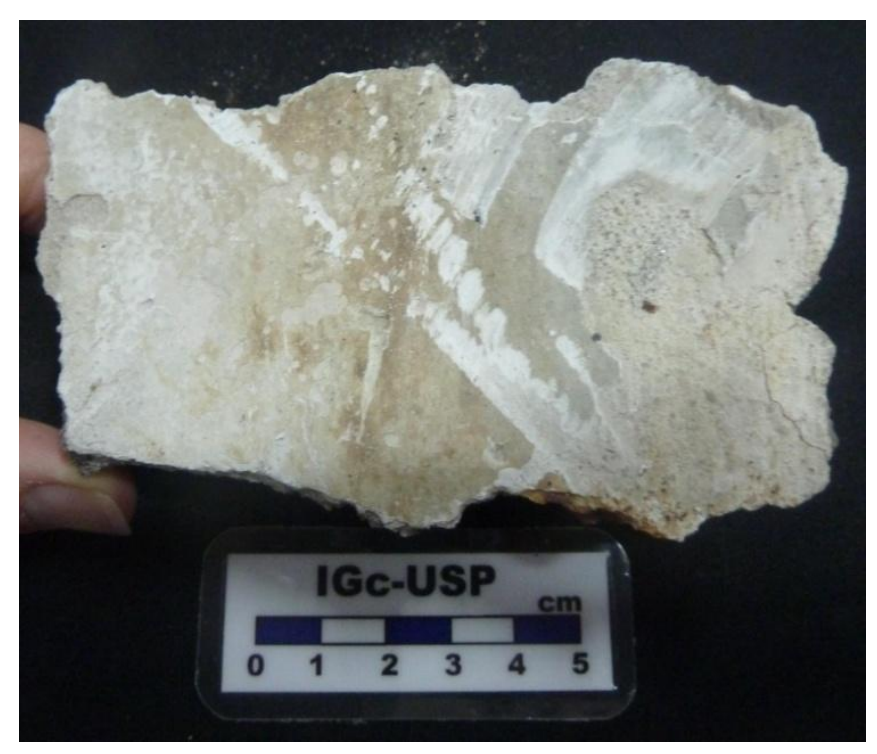

Figura 32: Amostra 02.

No corte estratigráfico (Figuras $33_{\mathrm{A}}$ e $33_{\mathrm{B}}$ ), é possível distinguir quatro camadas. A camada externa ('P') possui espessura da ordem de micrômetros e cor cinza. A camada 'Il' é branca acinzentada e também possui espessura micrométrica. A camada ' ' ' tem espessura bastante irregular, que vai de $1 \mathrm{~mm}$ a $4 \mathrm{~mm}$ neste corte. $O$ aglomerante possui cor branca rosada, e os agregados são subarredondados de esfericidade alta, mal selecionados - areia fina a grossa. A camada ' 0 ' possui aglomerante bem mais escuro, de cor cinza, e agregados mal selecionados - areia fina a grânulo, angulosos de esfericidade baixa. A espessura desta última camada não pode ser definida, mas fica claro que se trata de argamassa aplicada durante reforma feita no local, pois possui em seu interior restos de um conduíte de plástico (tubo plástico embutido em paredes usado para passagem da fiação elétrica). 

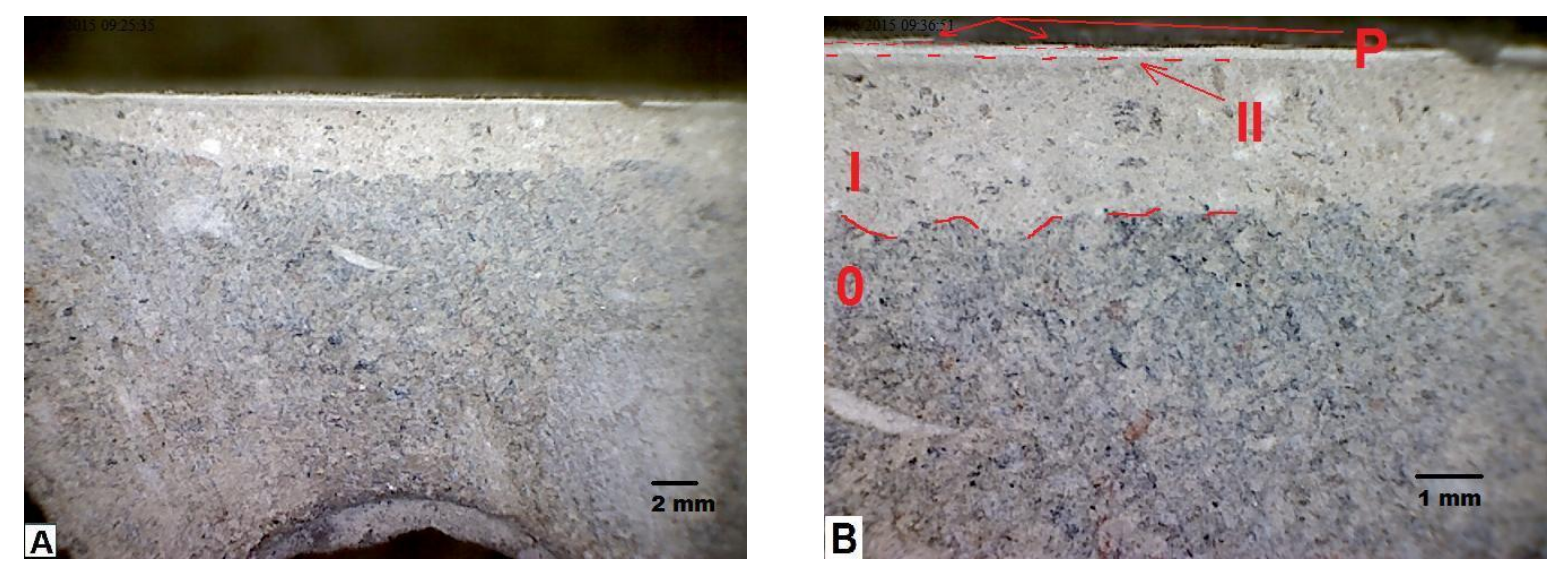

Figura 33 $\mathrm{A}$ : Corte estratigráfico da amostra 02. 33 $\mathrm{B}$ : Tracejados e setas indicam os contatos entre as diferentes camadas da amostra 02 visíveis a olho nu.

Não foram feitos testes de dureza dos materiais, mas é notável a diferença entre os aglomerantes das camadas 'l' e '0': o da camada 'l' possui dureza bastante baixa, podendo ser riscado com a unha; já o da camada '0' possui dureza mais alta, não riscável pela unha. Essa diferença também ficou evidente quando o material foi submetido a corte, na cortadeira de precisão (Figura $6_{\mathrm{A}}$ ), pois enquanto a camada "I" é facilmente desbastada, a camada "0" apresenta resistência significativamente maior. 


\subsubsection{DESCRIÇÃO PETROGRÁFICA}

Nas Figuras $34_{A}$ e $34_{B}$, a camada ' $P$ ' descrita anteriormente se revela como duas camadas, aqui chamadas $P_{0}$ e $P_{1}$. É possível individualizar raros grãos minerais muito finos dispersos por essas camadas, pois são compostas essencialmente por material amorfo, evidenciado pelo comportamento opaco da pasta que envolve esses grãos.

A camada 'Il' neste corte se apresenta bem menos espessa se comparada com a porção evidente no corte do fragmento desta amostra analisada no MEV/EDS (Figuras $40_{A}$ e $40_{B}$ ). Isso mostra como sua espessura é irregular. Como podemos ver nas Figuras $35_{\mathrm{A}}$ e $35_{\mathrm{B}}$, é formada por grãos de calcita e dolomita (informação confirmada pelos mapas composicionais feitos no MEV/EDS, que mostram quantidade significativa também de magnésio nestes grãos) bem selecionados - de 10 a $20 \mu \mathrm{m}$ em média, e raros grãos de outros minerais, envolvidos por material argiloso com aspecto de lama carbonática.

A camada 'l' (Figuras $36_{\mathrm{A}}$ e $36_{\mathrm{B}}$ ) possui agregado de mineralogia diversa, composto na maior parte por grãos de quartzo, micas e torrões de argila, estes em quantidades aproximadamente equivalentes, e em menor quantidade grãos de feldspato, envolvidos por matriz argilosa. Os grãos são na sua maioria subarredondados de esfericidade média, e granulometria desde 20 até $500 \mu \mathrm{m}$.

A camada ' 0 ' (Figuras $36_{\mathrm{A}}$ e $36_{\mathrm{B}}$ ) possui como aglomerante material argiloso, agregados angulosos, de esfericidade baixa, com granulometria desde $10 \mu \mathrm{m}$ até mais de $1 \mathrm{~mm}$, com predomínio de grãos de quartzo, e secundariamente de feldspatos. 

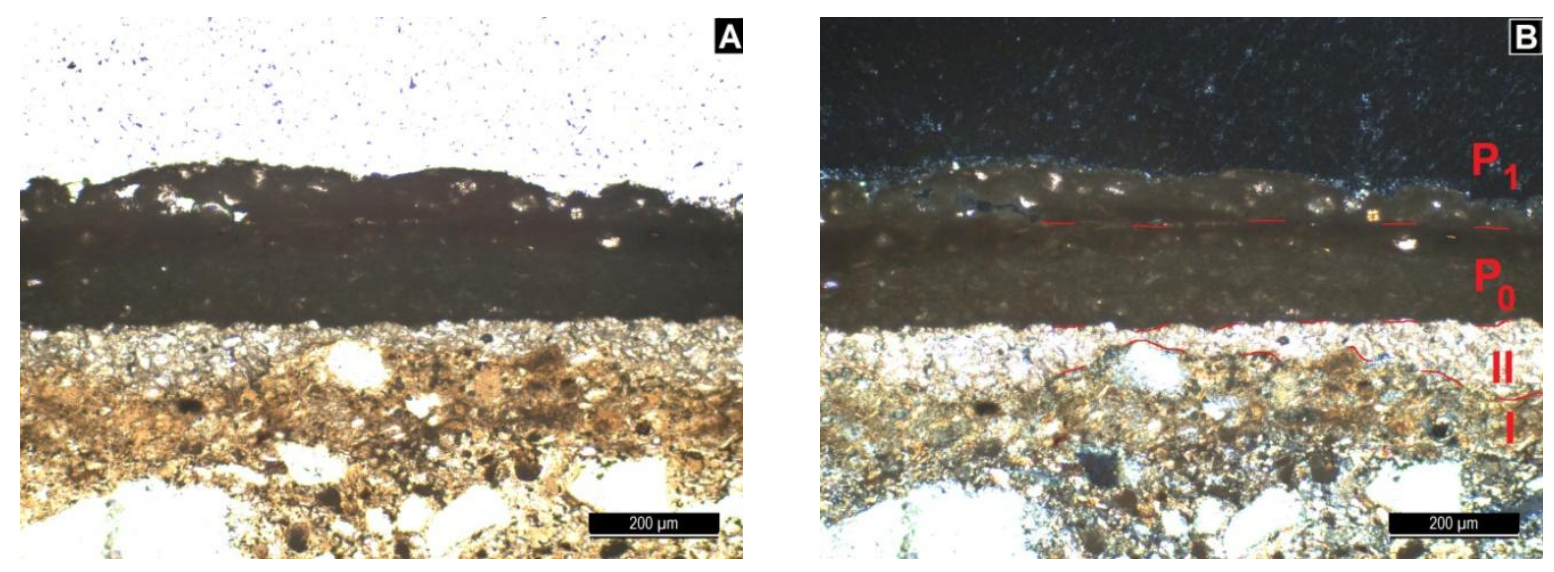

Figura 34: Fotomicrografia da amostra 02. A: Polarizadores paralelos. B: Polarizadores cruzados.
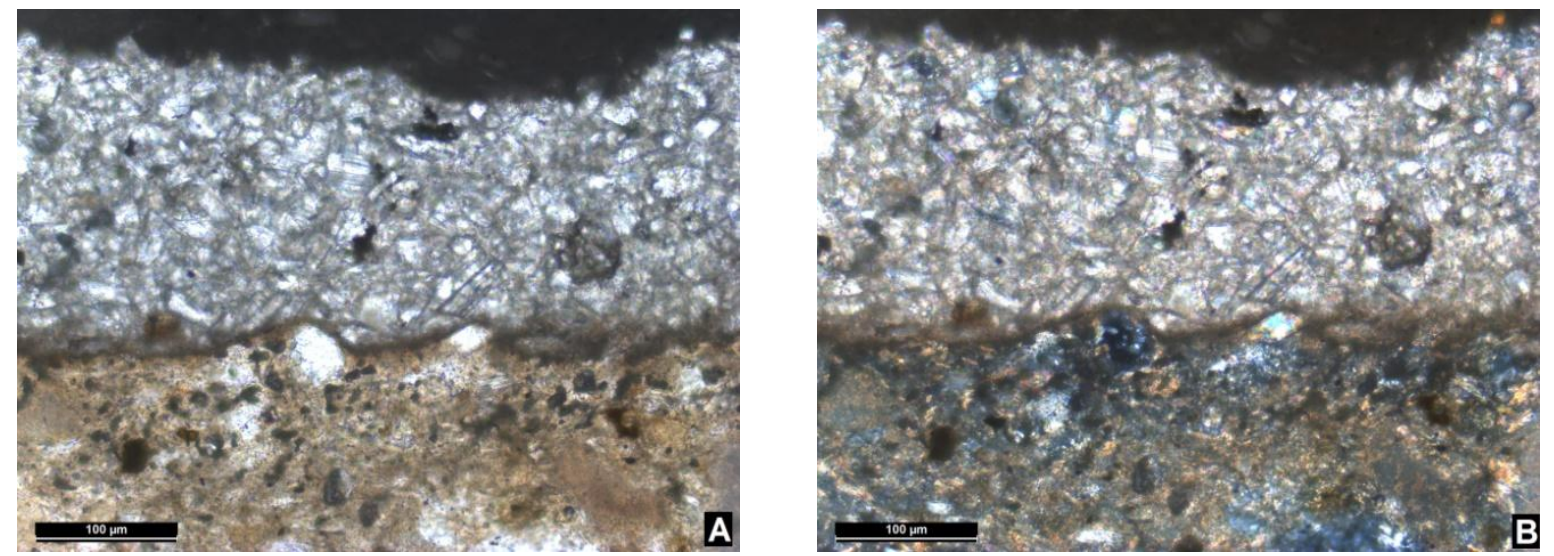

Figura 35: Fotomicrografia da amostra 02, enfocando a camada 'Il'. A: Polarizadores paralelos. B: Polarizadores cruzados.
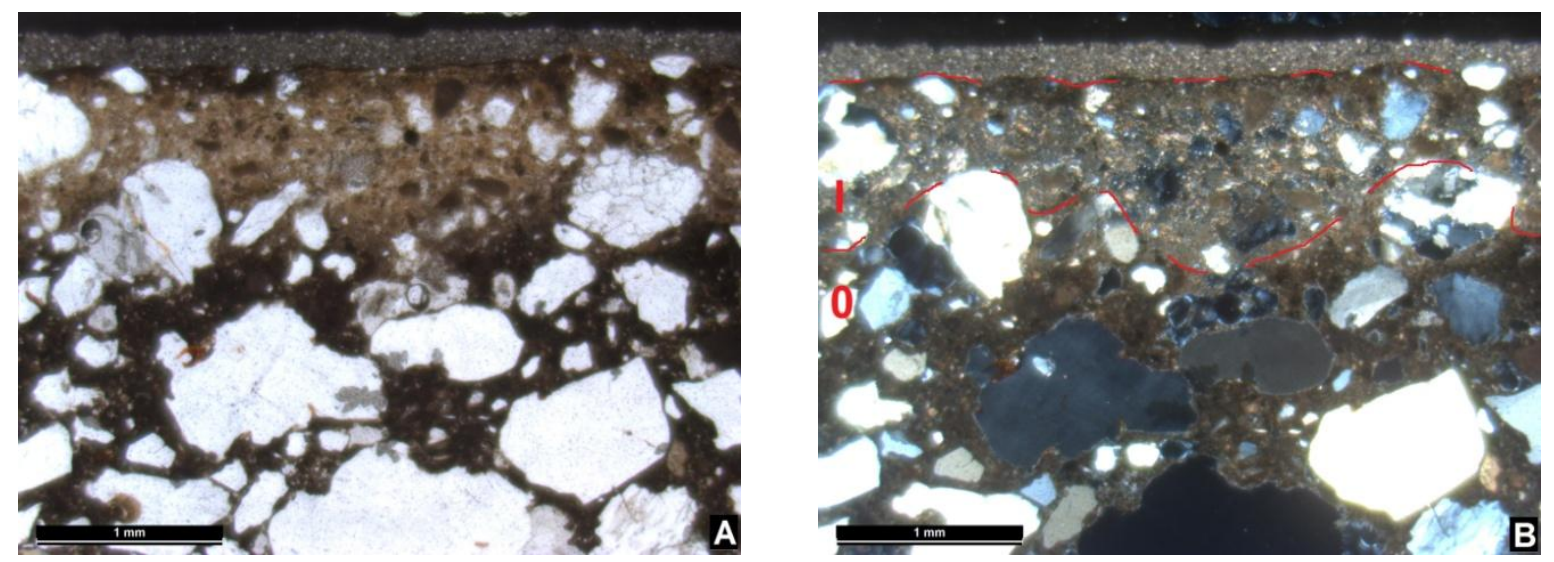

Figura 36: Fotomicrografia da amostra 02, com destaque para as camadas '0' e 'l'. A: Polarizadores paralelos. B: Polarizadores cruzados. Tracejado indica o contato entre as duas camadas. 
Nas camadas ' 0 ' e 'l', além dos agregados, há grãos que correspondem a porções de clínquer de cimento Portland que não foram completamente hidratados (Figuras $37_{A}, 37_{B}, 38_{A}$ e $\left.38_{B}\right)$. Isso demonstra que em ambas as camadas houve a adição deste material, e que o mesmo não se encontrava finamente moído.

Na camada '0' (que, conforme descrição macroscópica, apresenta cor cinza escuro e dureza alta) esses grãos possuem entre 100 e 200 um de diâmetro em média, e representam aproximadamente $10 \%$ do material que compõe a matriz. Há também nesta matriz entre 3 e $5 \%$ de grumos de material opaco.

A camada 'l' (de cor branca rosada e dureza baixa) possui apenas traços destes grãos de clínquer, que possuem diâmetro entre 50 e 100 ㅆm aproximadamente.
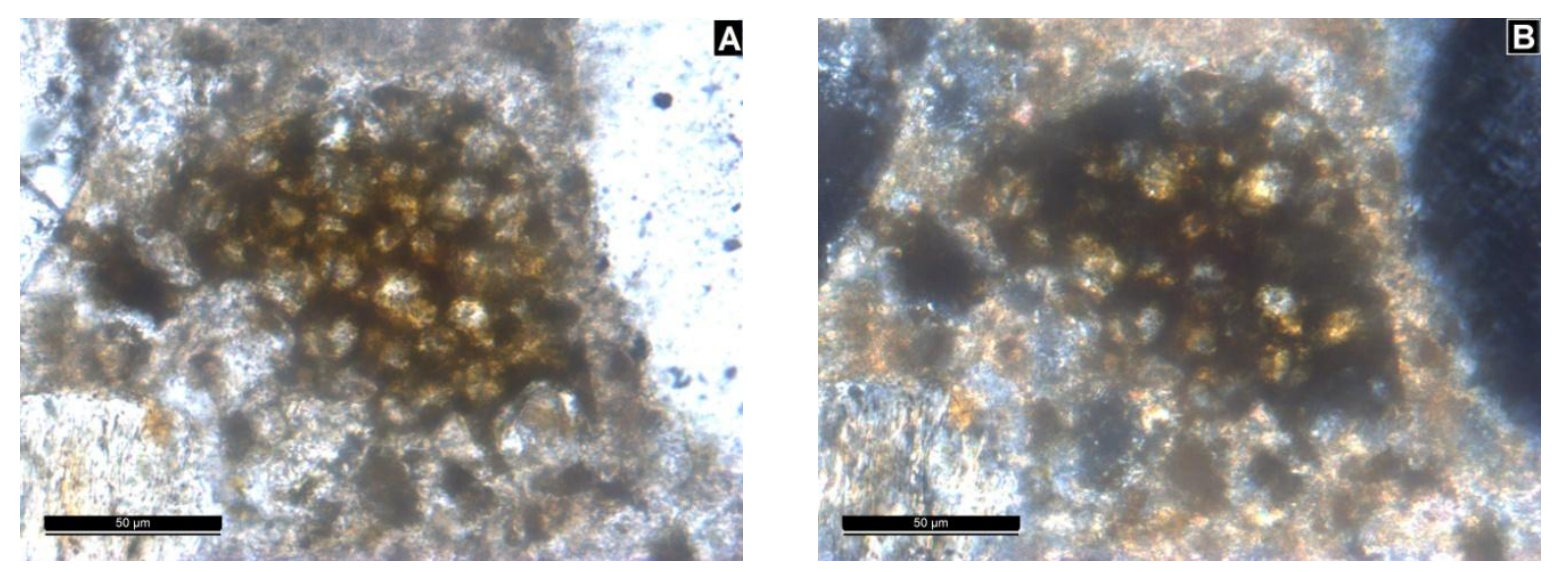

Figura 37: Fotomicrografia da amostra 02. Grãos de clínquer de cimento Portland presentes na camada ' 0 '. A: Polarizadores paralelos. B: Polarizadores cruzados.
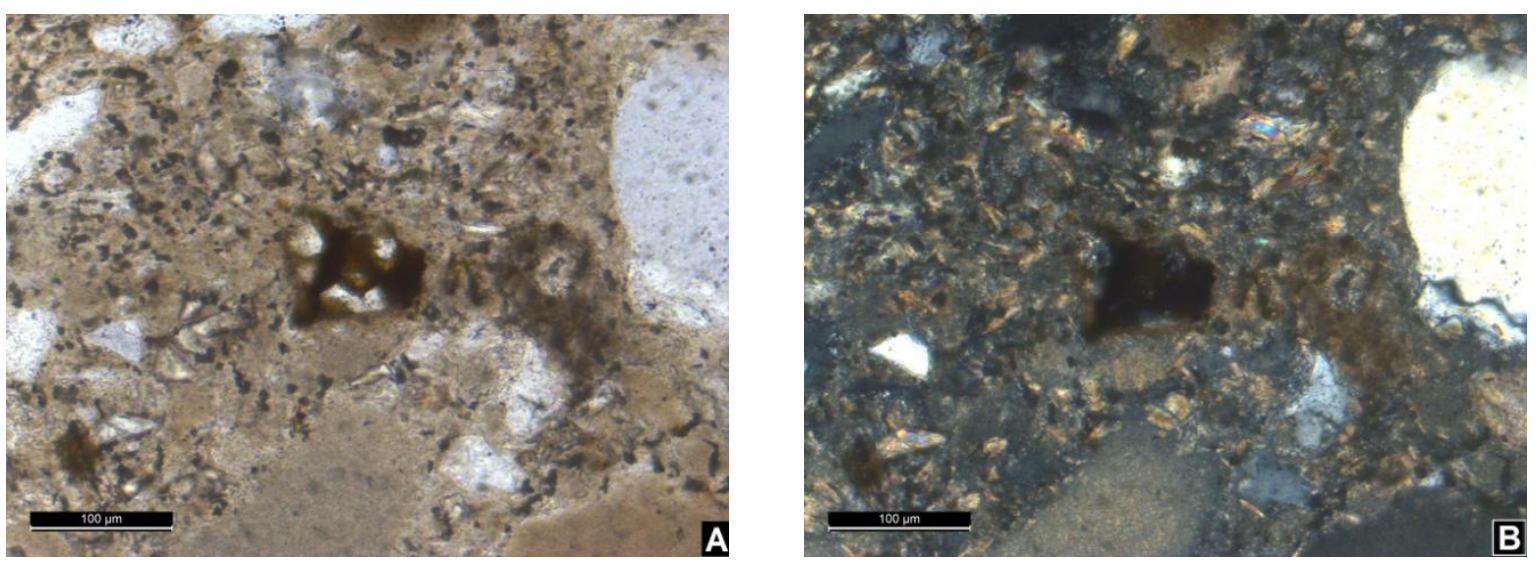

Figura 38: Fotomicrografia da amostra 02. Grãos de clínquer de cimento Portland presentes na camada 'l'. A: Polarizadores paralelos. B: Polarizadores cruzados. 


\subsubsection{MEV/EDS - CORTE ESTRATIGRÁFICO}

A Figura $39_{A}$ mostra o fragmento embutido em resina da amostra 02 , e a Figura $39_{B}$ mostra a região deste fragmento que foi analisada no MEV/EDS.
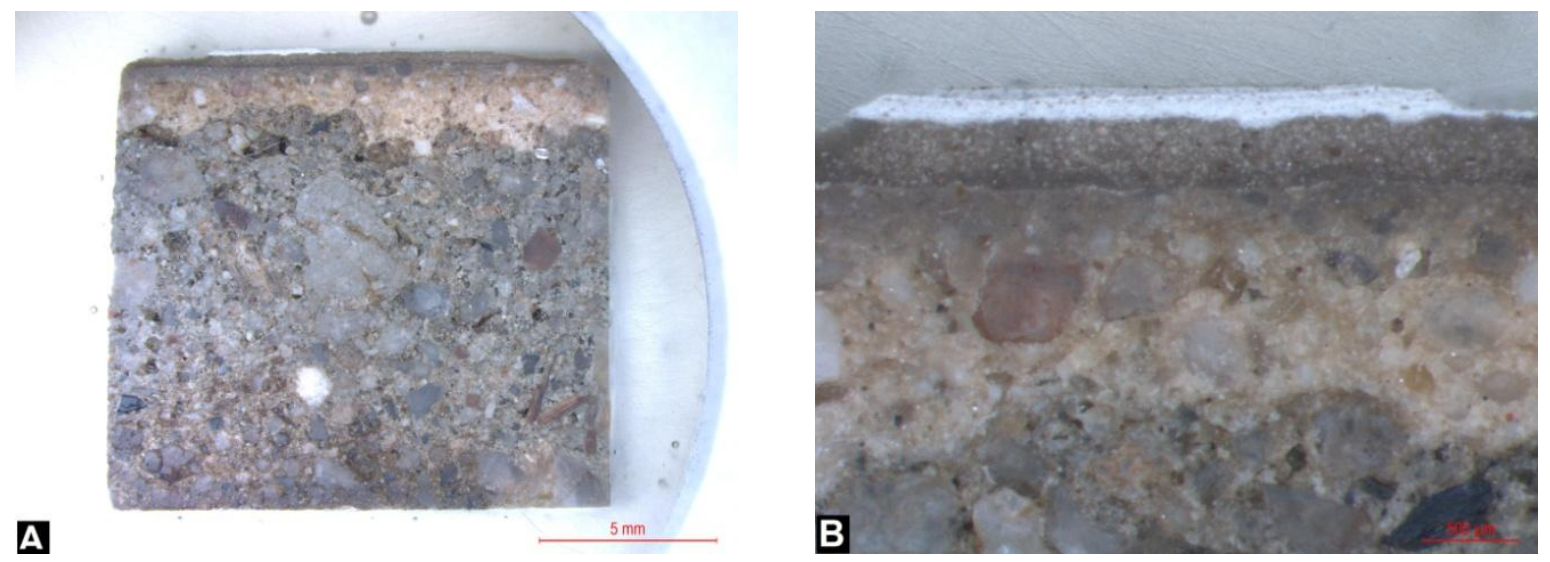

Figura 39: Fragmento da amostra 02 embutido em resina para ser analisado em MEV/EDS. 39B: Região do fragmento da amostra 02 analisada no MEV/EDS.

As amostras 02 e 04, a partir dos materiais que as compõem, foram consideradas como fruto de reforma posterior à manufatura da obra artística, conforme resumido nos itens 'Conclusões sobre a amostra 02' e 'Conclusões sobre a amostra 04'. Por isso, foram adotados protocolos ligeiramente diferentes de exposição dos dados coletados. As análises em MEV/EDS dos cortes estratigráficos foram divididas em duas partes: mapeamentos composicionais, e leituras de espectros composicionais de áreas específicas de cada uma das camadas superiores.

As Figuras $40_{\mathrm{A}}$ e $40_{\mathrm{B}}$ mostram as áreas da amostra 02 usadas para os mapeamentos composicionais dos seguintes elementos: $\mathrm{Ca}, \mathrm{Mg}, \mathrm{Al}, \mathrm{K}, \mathrm{Si}, \mathrm{Ti}, \mathrm{Fe}$, $\mathrm{Na}, \mathrm{P}$ e $\mathrm{S}$, sendo que os quatro últimos não apresentaram distribuição nos mapas. Os tracejados indicam os contatos entre as diferentes camadas.

A Figura 41 mostra as quatro áreas a partir das quais foram lidos espectros composicionais pelo EDS. 

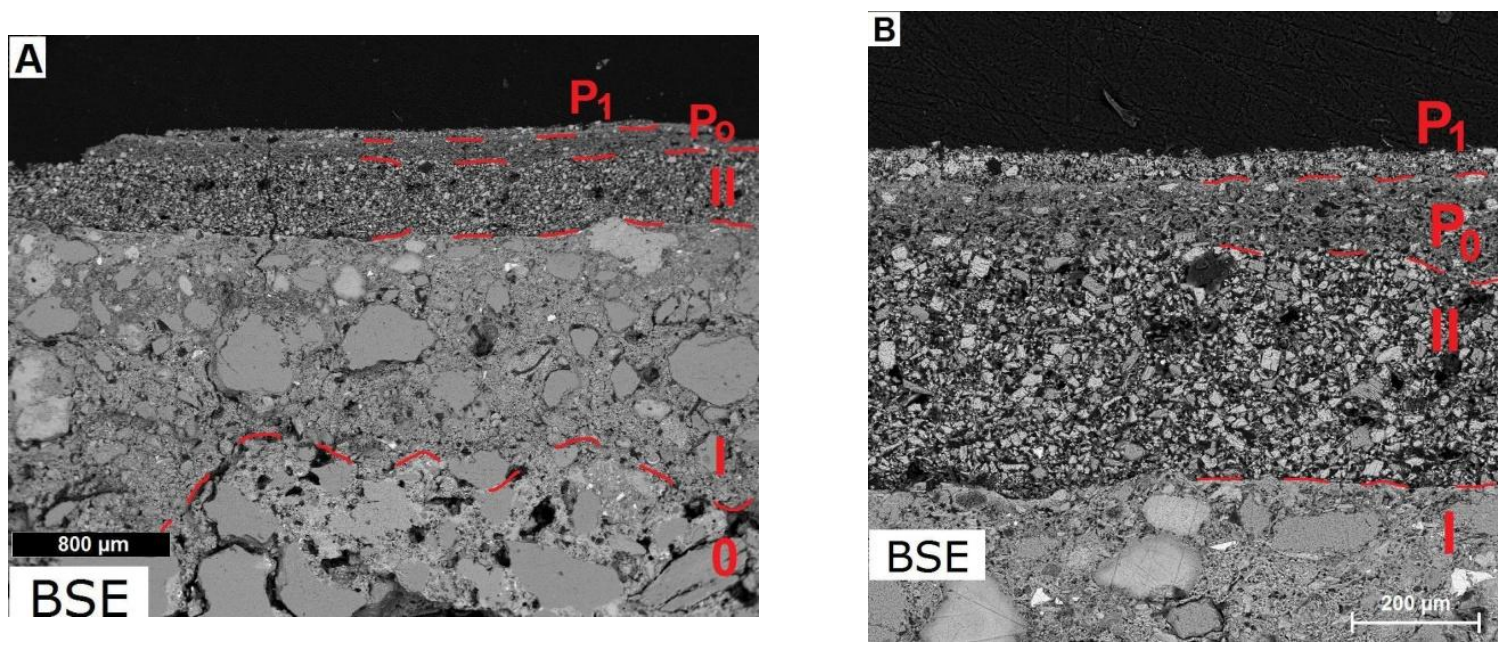

Figura 40: Áreas da amostra 02 analisadas em MEV, submetidas a mapeamentos composicionais por EDS. Imagens de elétrons retroespalhados. Tracejados indicam os contatos entre as diferentes camadas.

A: Primeira área; B: Segunda área, enfocando as camadas superiores.

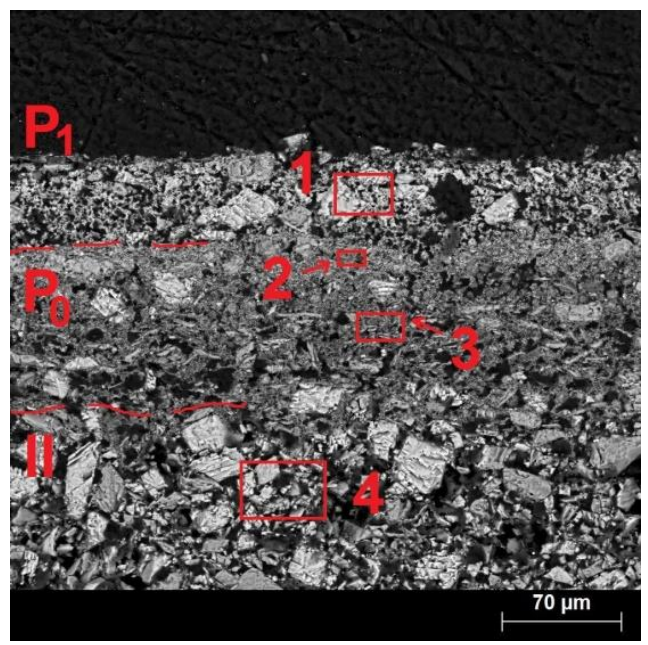

Figura 41: Os retângulos indicam as áreas, nas camadas superiores da amostra 02 , de onde foram lidos espectros composicionais por EDS.

Antes de discorrer sobre os dados coletados, valem algumas observações. Esta descrição aborda os aspectos estratigráfico, composicional e textural das amostras, e os mapeamentos composicionais por EDS gerando imagens a partir das quais podem-se observar as relações texturais. Os elementos químicos escolhidos para figurar nos mapeamentos composicionais são os que comumente fazem parte dos materiais que compõem os afrescos (objeto deste estudo), não abarcando portanto elementos presentes em produtos como tintas industrializadas ou massas para acabamento de paredes, como são os casos das amostras 02 e 04. Nos espectros 
composicionais aparecem elementos que, por não figurarem nos mapeamentos, não se pode afirmar seu posicionamento dentro das relações texturais.

Para as descrições texturais, será feita uma diferenciação entre materiais pela granulometria, se dizem respeito a grãos ou material argiloso. Pode-se tomar como base as medidas conhecidas da escala de Wentworth de classificação granulométrica.

Observando em conjunto os mapeamentos composicionais das Figuras 42 a 47 e os espectros composicionais das Figuras 48 a 51, podem ser destacados os seguintes aspectos:

- a camada $\mathrm{P}_{1}$ (camada externa) é rica nos elementos $\mathrm{Ca}$ e Ti. O Ca está presente tanto na forma de grãos, de dimensões médias entre 10 e $20 \mu \mathrm{m}$, quanto no material fino (argiloso) que envolve os grãos; o Ti aparece no material argiloso. A camada $\mathrm{P}_{0}$ contém os elementos $\mathrm{Ti}, \mathrm{Si}, \mathrm{Al}, \mathrm{K}, \mathrm{Ca}, \mathrm{Cl}$ e Mg. Pelos mapas composicionais, podese observar que os elementos $\mathrm{Ti}, \mathrm{Si}, \mathrm{Al}$ e $\mathrm{K}$ fazem parte do material fino que envolve grãos compostos de $\mathrm{Ca}, \mathrm{Si}$, e em menor quantidade $\mathrm{Mg}$ ( $\mathrm{Cl}$ não faz parte dos elementos que figuram nos mapeamentos composicionais). Esses são todos elementos presentes em diferentes composições de tintas industrializadas para paredes (Tavares, 2011; Anghinetti, 2012).

- a camada 'll' é composta de $\mathrm{Ca}, \mathrm{Mg}, \mathrm{Si}$ e $\mathrm{Cl}$, sendo rico em Ca o material fino que envolve os grãos, que possuem $\mathrm{Ca}, \mathrm{Mg}$ e $\mathrm{Si}$ em suas composições. (Não foi feito mapa composicional para o elemento $\mathrm{Cl}$ ). Pelas características materiais e texturais macro e microscópicas, assim como por sua posição na estratigrafia, esta camada é aqui interpretada como massa industrial para acabamento de paredes. (Vale lembrar que não faz parte do escopo deste trabalho caracterizar materiais que não façam parte da pintura original do artista).

As camadas ' $l$ ' e ' 0 ' não tiveram áreas submetidas a leitura de espectros composicionais. Ambas possuem como aglomerante material rico em $\mathrm{Ca}, \mathrm{Mg}, \mathrm{Al}, \mathrm{K}$, e em menor quantidade Si (Figuras 42 a 46). Apesar de possuírem composições similares, diferem nas concentrações desses elementos. $O$ agregado aparece nos mapas composicionais confirmando a informação da descrição petrográfica, com predomínio de grãos de quartzo, e secundariamente micas, feldspatos e fragmentos de lama carbonática. 

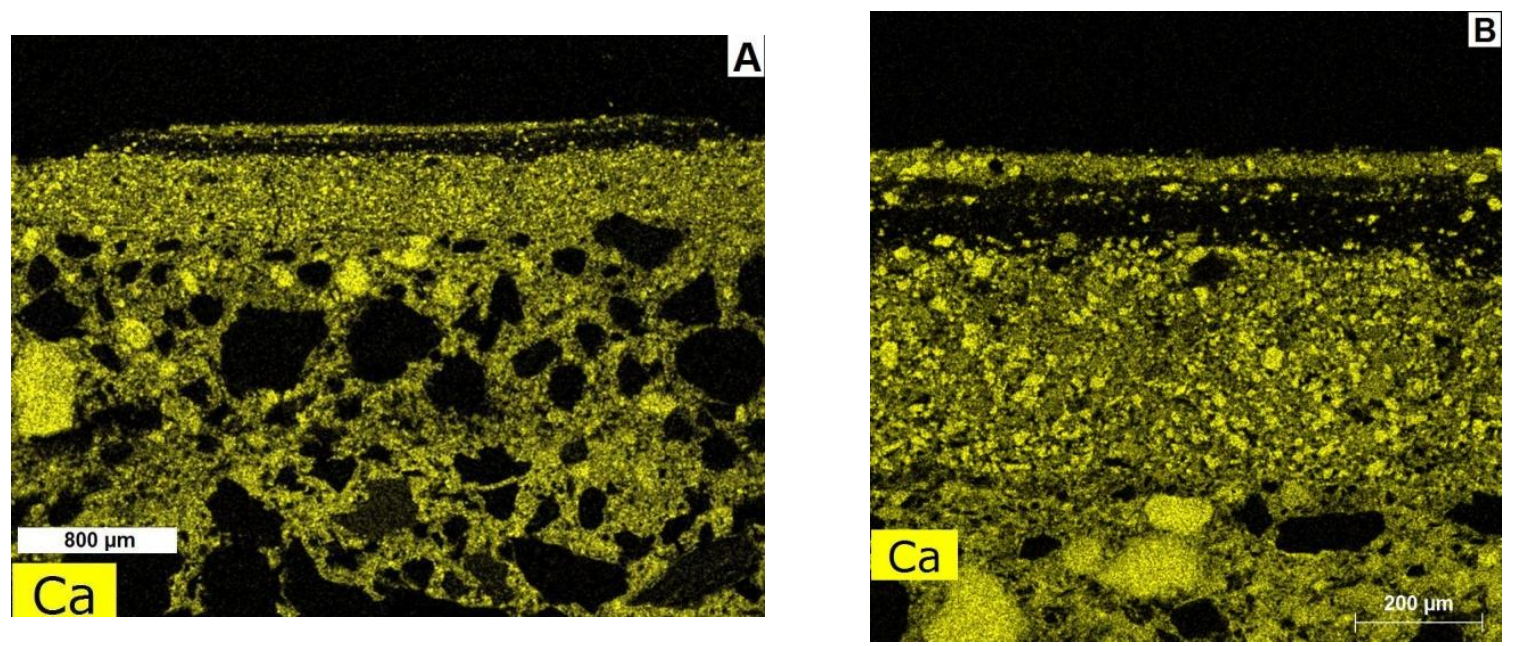

Figura 42: Mapeamento composicional do elemento Ca feito por EDS na amostra 02. A: Área mapeada total; B: Detalhe com enfoque nas camadas superiores.
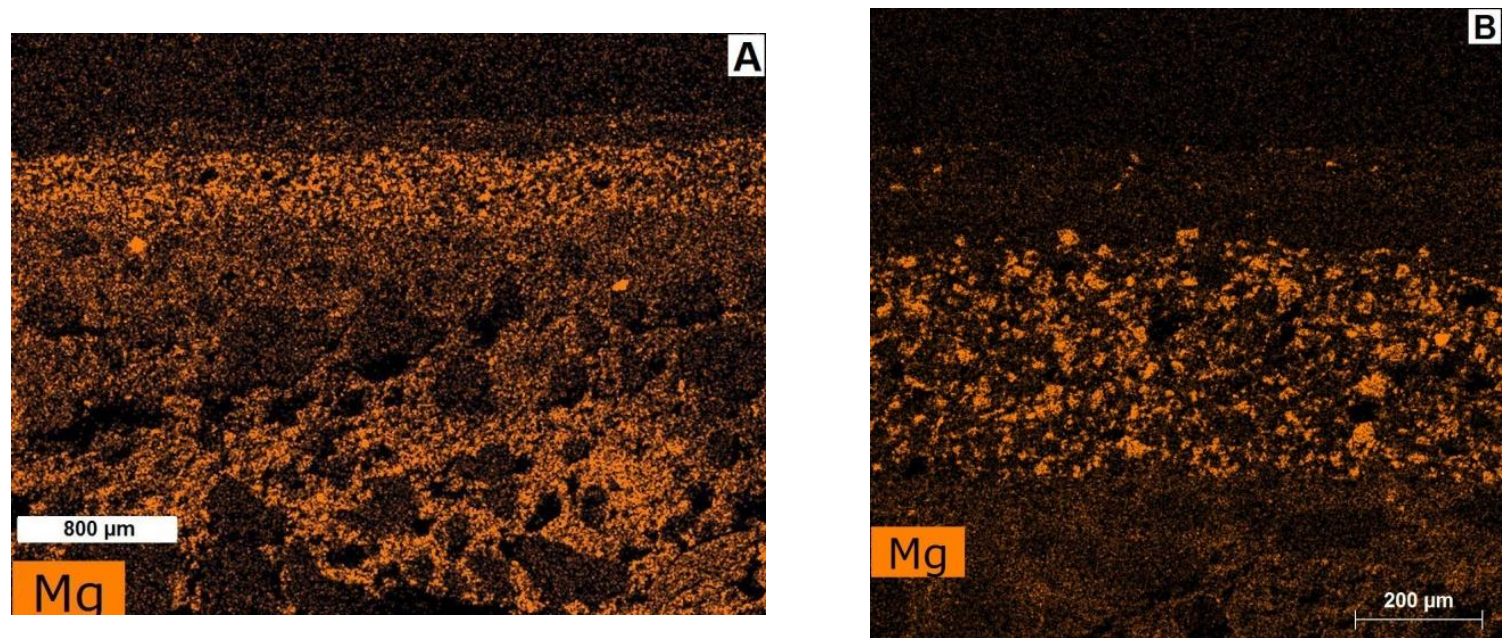

Figura 43: Mapeamento composicional do elemento Mg feito por EDS na amostra 02. A: Área mapeada total; B: Detalhe com enfoque nas camadas superiores.
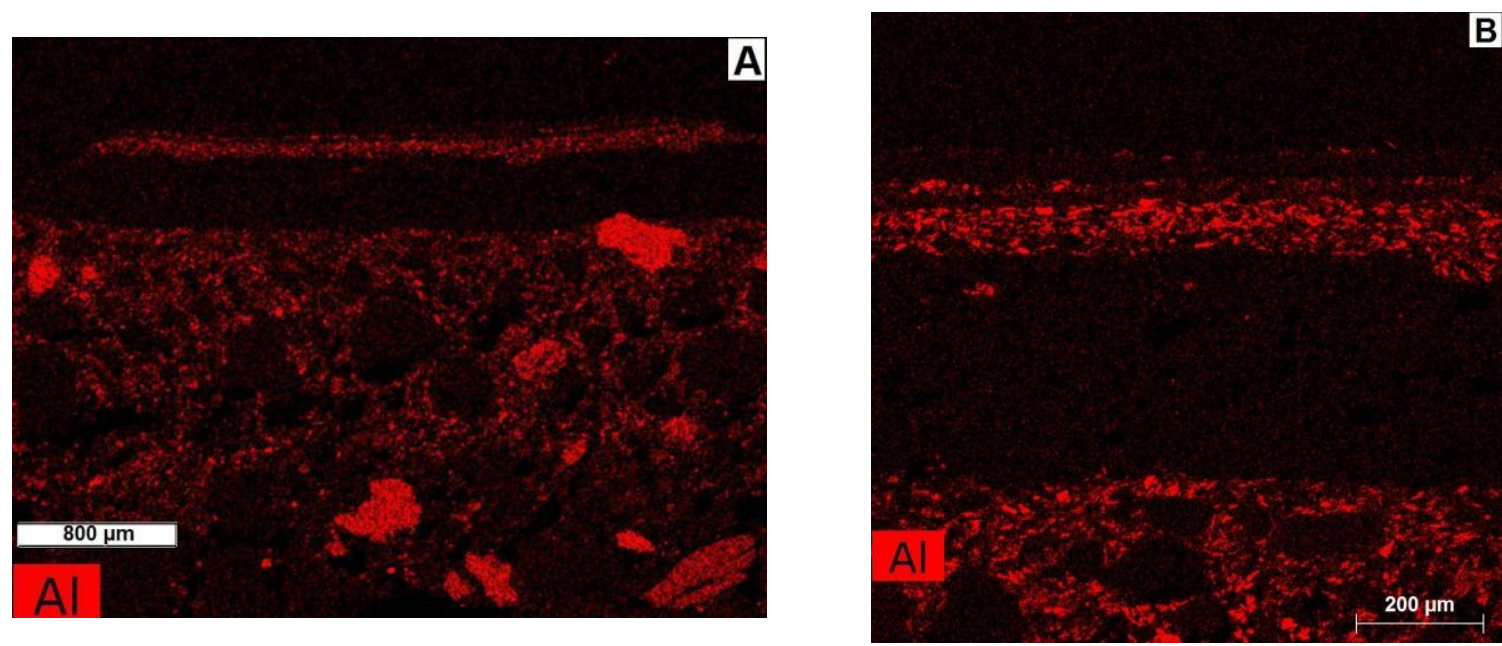

Figura 44: Mapeamento composicional do elemento Al feito por EDS na amostra 02. A: Área mapeada total; B: Detalhe com enfoque nas camadas superiores. 

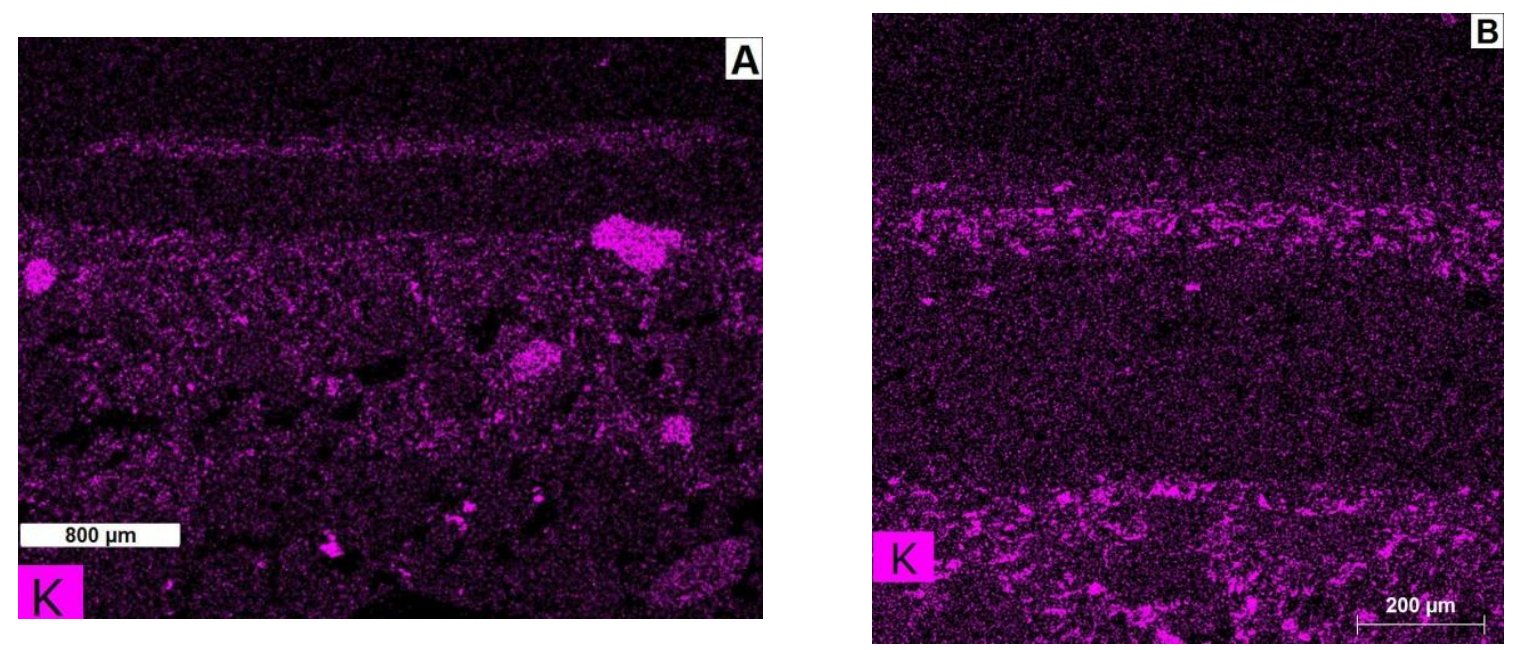

Figura 45: Mapeamento composicional do elemento $\mathrm{K}$ feito por EDS na amostra 02. A: Área mapeada total; B: Detalhe com enfoque nas camadas superiores.
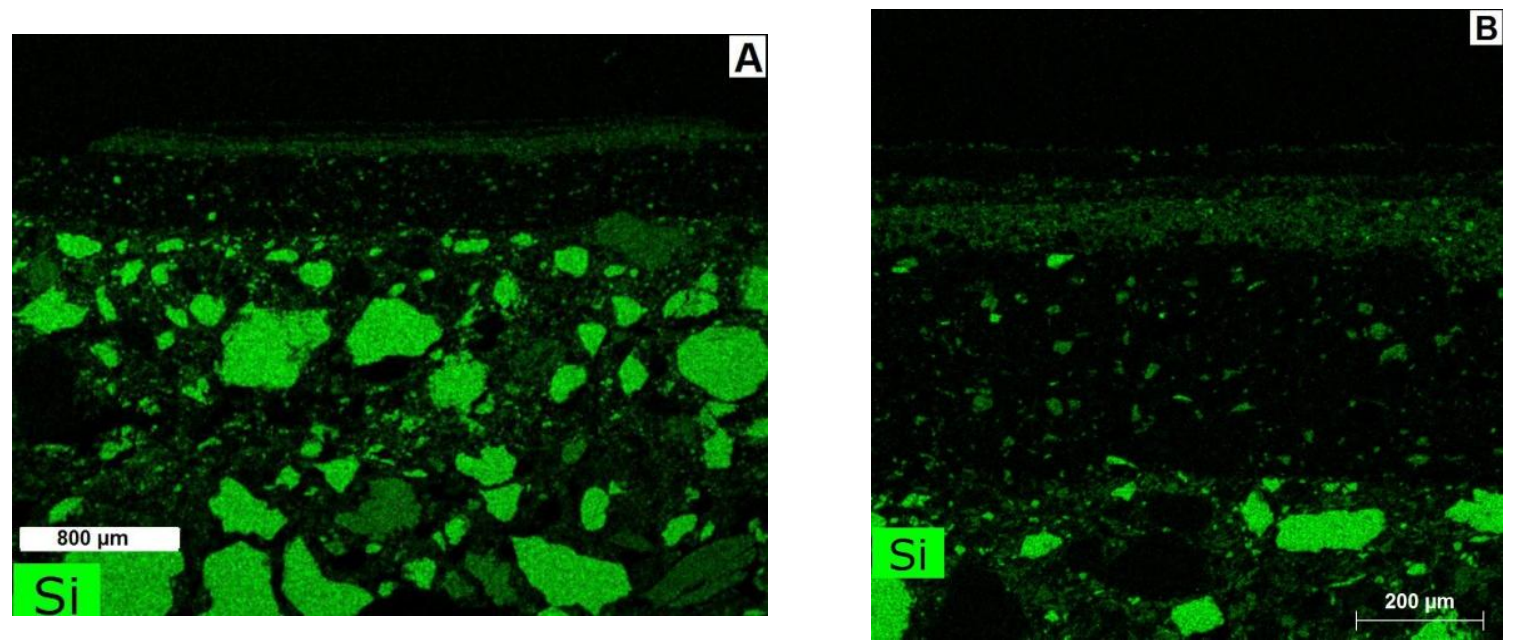

Figura 46: Mapeamento composicional do elemento Si feito por EDS na amostra 02. A: Área mapeada total; B: Detalhe com enfoque nas camadas superiores.
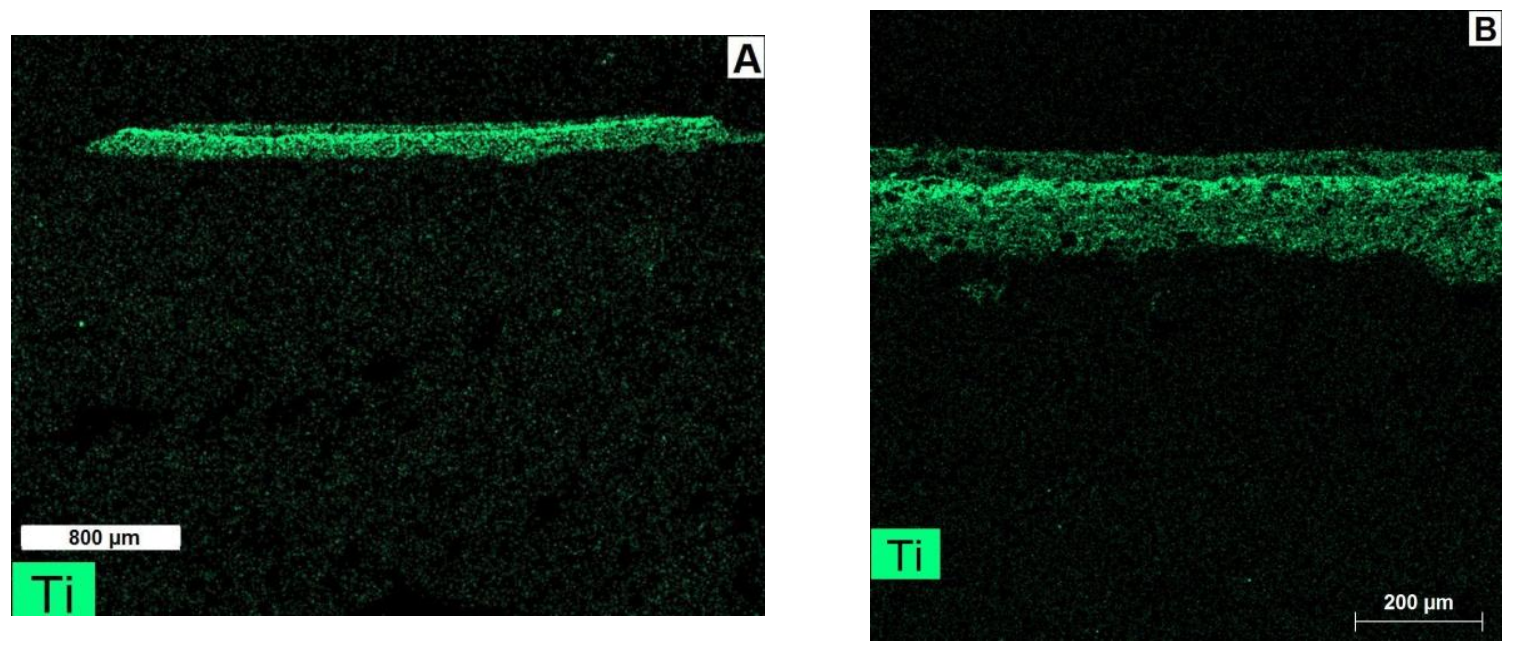

Figura 47: Mapeamento composicional do elemento Ti feito por EDS na amostra 02. A: Área mapeada total; B: Detalhe com enfoque nas camadas superiores. 


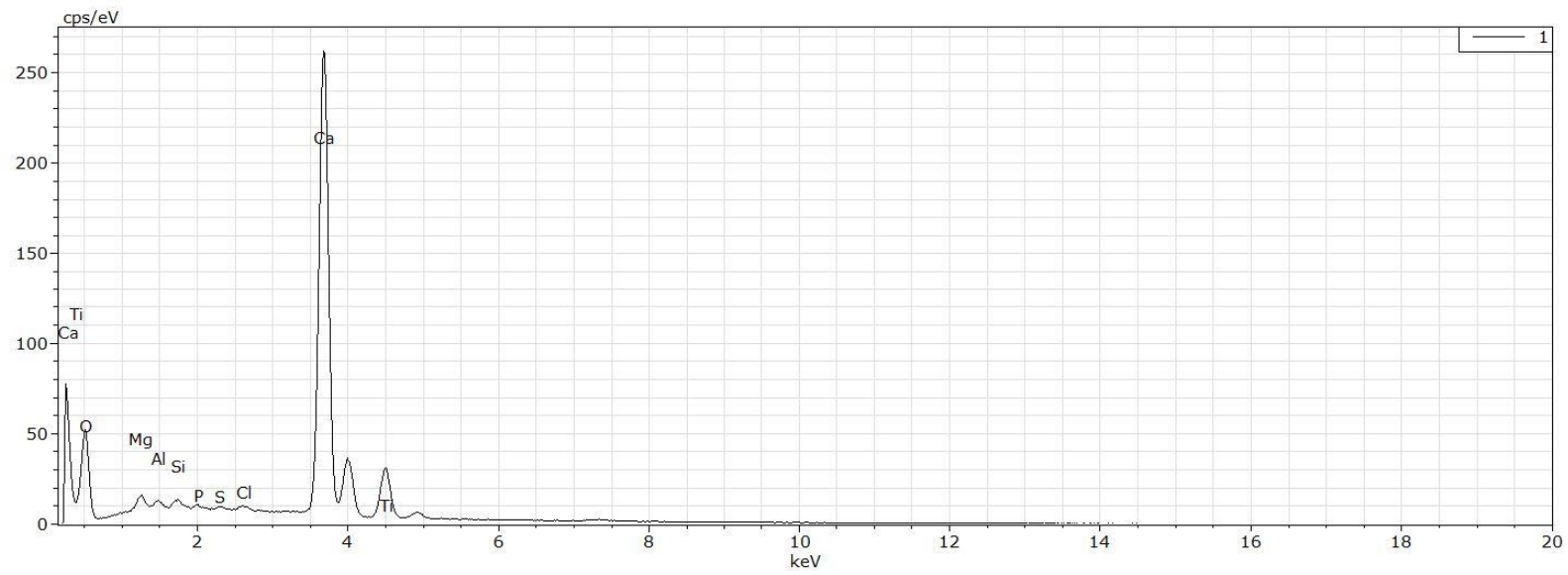

Figura 48: Espectro composicional por EDS da área '1', dentro da camada $\mathrm{P}_{1}$, marcada na Figura 41.

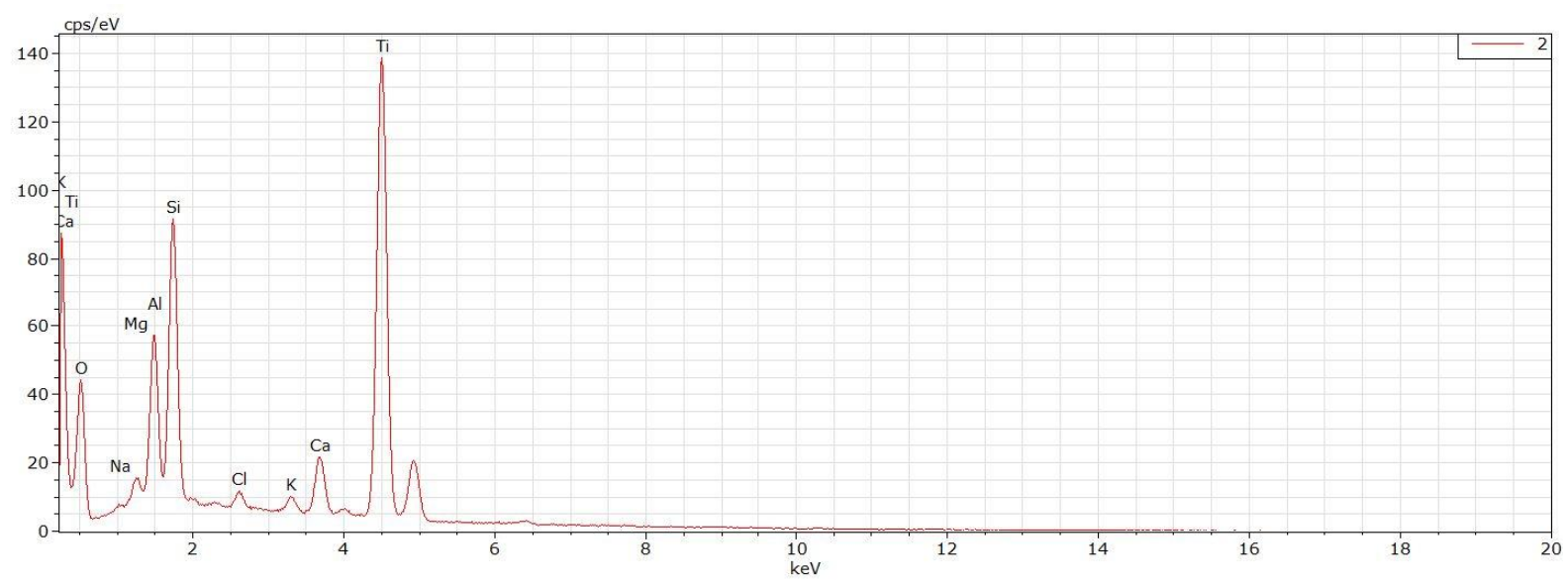

Figura 49: Espectro composicional por EDS da área '2', dentro da camada $\mathrm{P}_{0}$, marcada na Figura 41.

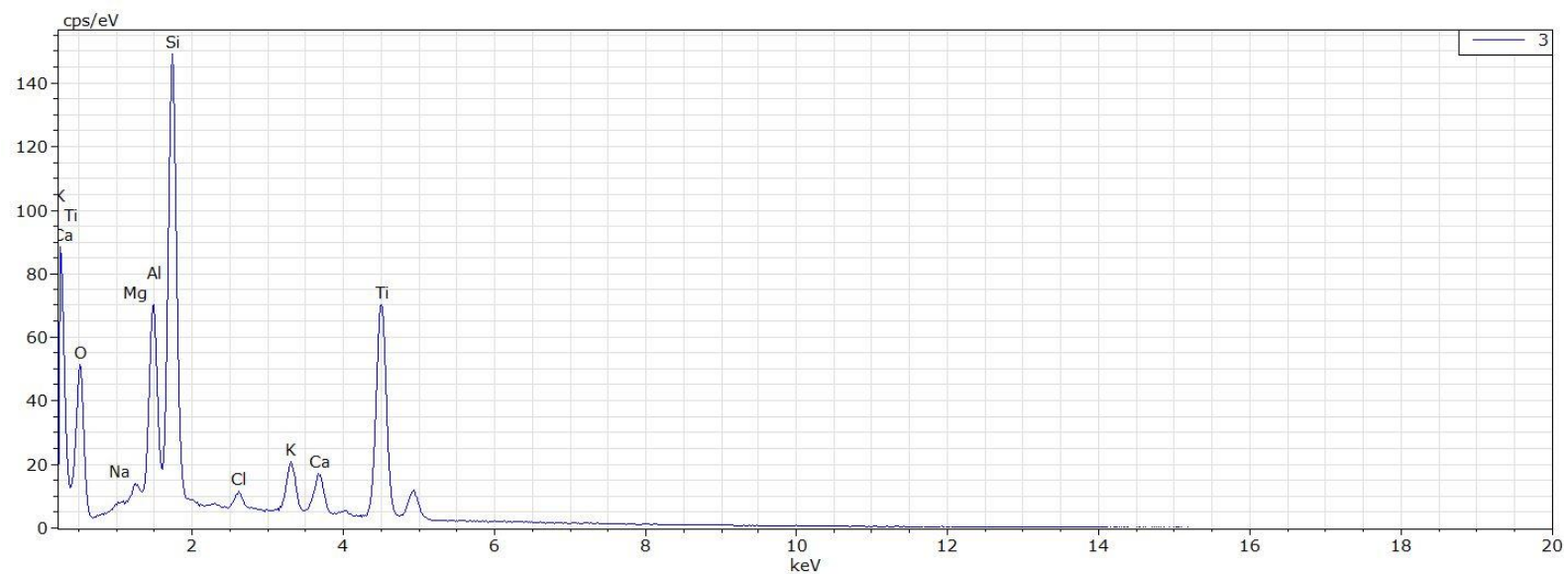

Figura 50: Espectro composicional por EDS da área ' 3 ', dentro da camada $\mathrm{P}_{0}$, marcada na Figura 41. 


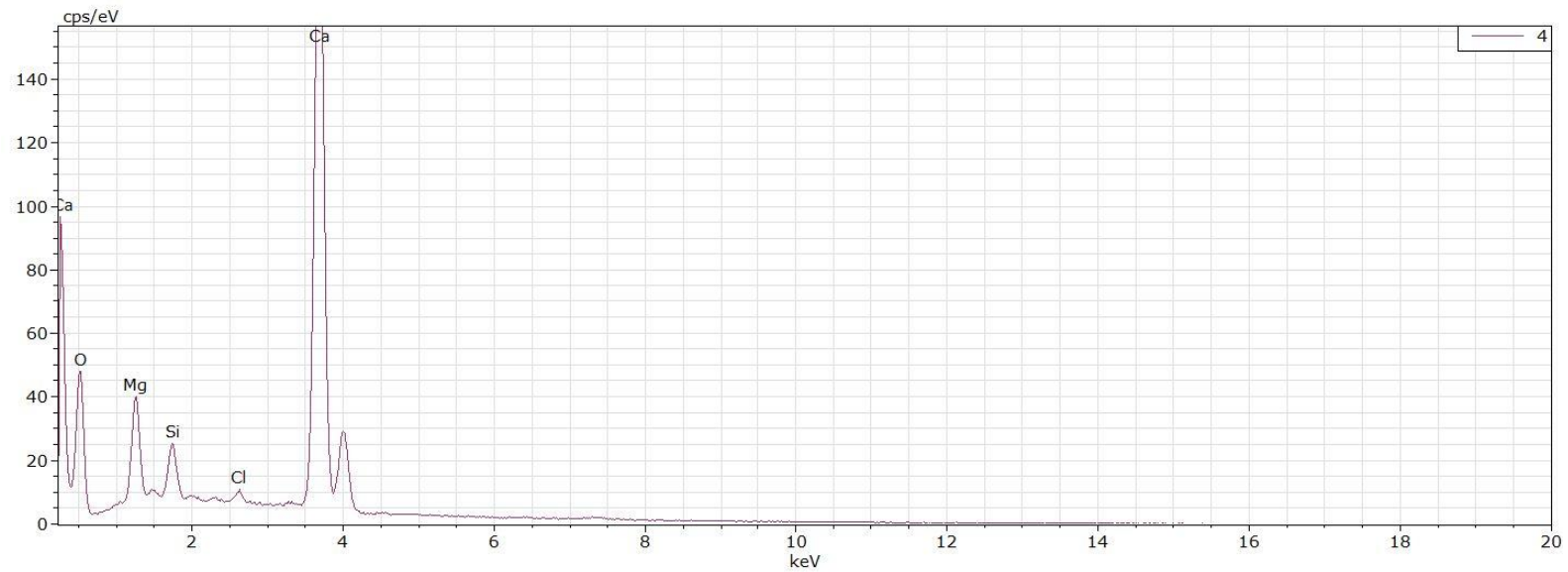

Figura 51: Espectro composicional por EDS da área '4', dentro da camada 'Il', marcada na Figura 41. 


\subsubsection{FLUORESCÊNCIA DE RAIOS X}

Os dados de Fluorescência de Raios X ressaltados em vermelho na Tabela 2 mostram os elementos que se destacam na varredura superficial semiquantitativa da amostra 02. Como a amostra apresenta perda superficial de material, componentes de diferentes camadas aparecem em quantidades significativas. Sobressaem-se nesta análise os elementos $\mathrm{Ca}$ e $\mathrm{Ti}$, principais componentes da camada externa da amostra (composta de tinta industrializada).

Tabela 2: Dados semiquantitativos (\%) de espectrometria de fluorescência de raios $X$ de varredura superficial, de todas as amostras para comparação.

\begin{tabular}{|c|c|c|c|c|c|}
\hline AMOSTRA & 01 & 02 & 03 & 04 & 05 \\
\hline Sum sem norm & 75,7 & 88,8 & 67,3 & 82,7 & 66,4 \\
\hline $\mathrm{Na}_{2} \mathrm{O}$ & 014 & 0.096 & 0111 & 0073 & 0118 \\
\hline $\mathrm{MgO}$ & 5,177 & 4,533 & 47,342 & 4,902 & 9,187 \\
\hline $\mathrm{Al}_{2} \mathrm{O}_{3}$ & 3,662 & 4,341 & 3,478 & 6,188 & 6,812 \\
\hline $\mathrm{SiO}_{2}$ & 7,908 & 7,484 & 4,827 & 11,623 & 17,706 \\
\hline $\mathrm{P}_{2} \mathrm{O}_{5}$ & 0,094 & 0,291 & 0,091 & 0,184 & 0,263 \\
\hline $\mathrm{SO}_{3}$ & 5,834 & 1,179 & 0,517 & 0,828 & 2,105 \\
\hline $\mathrm{Cl}$ & 0,39 & 0,265 & 0,228 & 0,301 & 0,299 \\
\hline $\mathrm{K}_{2} \mathrm{O}$ & 0,31 & 0,419 & 0,208 & 1,16 & 0,541 \\
\hline $\mathrm{CaO}$ & 70,313 & 46,736 & 40,688 & 43,212 & 59,214 \\
\hline $\mathrm{TiO}_{2}$ & 2,614 & 33,64 & 0,777 & 30,615 & \\
\hline $\mathrm{Cr}$ & 0,013 & 0,018 & 0,012 & 0,026 & 0,019 \\
\hline $\mathrm{MnO}$ & 0,078 & 0,035 & 0,044 & 0,007 & \\
\hline $\mathrm{Fe}_{2} \mathrm{O}_{3}$ & 3,228 & 0,638 & 1,335 & 0,482 & 2,43 \\
\hline $\mathrm{Ni}$ & 0,004 & 0,005 & 0,007 & 0,005 & 0,006 \\
\hline $\mathrm{Cu}$ & 0,018 & 0,018 & 0,037 & 0,01 & 0,022 \\
\hline $\mathrm{Zn}$ & 0,037 & 0,076 & 0,091 & 0,023 & 0,138 \\
\hline $\mathrm{Rb}$ & 0,005 & 0,007 & 0,009 & 0,007 & 0,006 \\
\hline $\mathrm{Sr}$ & 0,105 & 0,089 & 0,021 & 0,043 & 0,059 \\
\hline$Y$ & 0,003 & 0,002 & 0,004 & 0,002 & 0,002 \\
\hline $\mathrm{Zr}$ & 0,033 & 0,031 & 0,038 & 0,019 & 0,027 \\
\hline $\mathrm{Ba}$ & 0,031 & 0,07 & 0,122 & 0,053 & 0,104 \\
\hline $\mathrm{Pb}$ & 0,004 & 0,019 & 0,011 & 0,011 & 0,015 \\
\hline $\mathrm{Br}$ & & & & & 0,002 \\
\hline $\mathrm{Ce}$ & & & & & 0,102 \\
\hline Co & & & & & 0,138 \\
\hline $\mathrm{F}$ & & & & 0,219 & 0,289 \\
\hline $\mathrm{Ga}$ & & 0,002 & & & \\
\hline $\mathrm{Mn}$ & & & & & 0,097 \\
\hline $\mathrm{Nb}$ & & 0,007 & & 0,008 & \\
\hline $\mathrm{Ti}$ & & & & & 0,298 \\
\hline
\end{tabular}




\subsubsection{LANTERNA UV}

A superfície da amostra 02 se comporta de maneiras distintas sob radiação UV (Figuras 52 $2_{A}$, e 52 $2_{B}$ para comparação), em função das diferentes profundidades de perda de material. Os locais onde está preservada a camada superficial (camada "P $\mathrm{P}_{1}$ ") emitem fluorescência, predominando azul claro. A camada " $\mathrm{P}_{0}$ " emite luz roxa de maneira bastante homogênea. Nas porções onde estão expostas as camadas inferiores não se observa um comportamento regular de emissão de fluorescência.
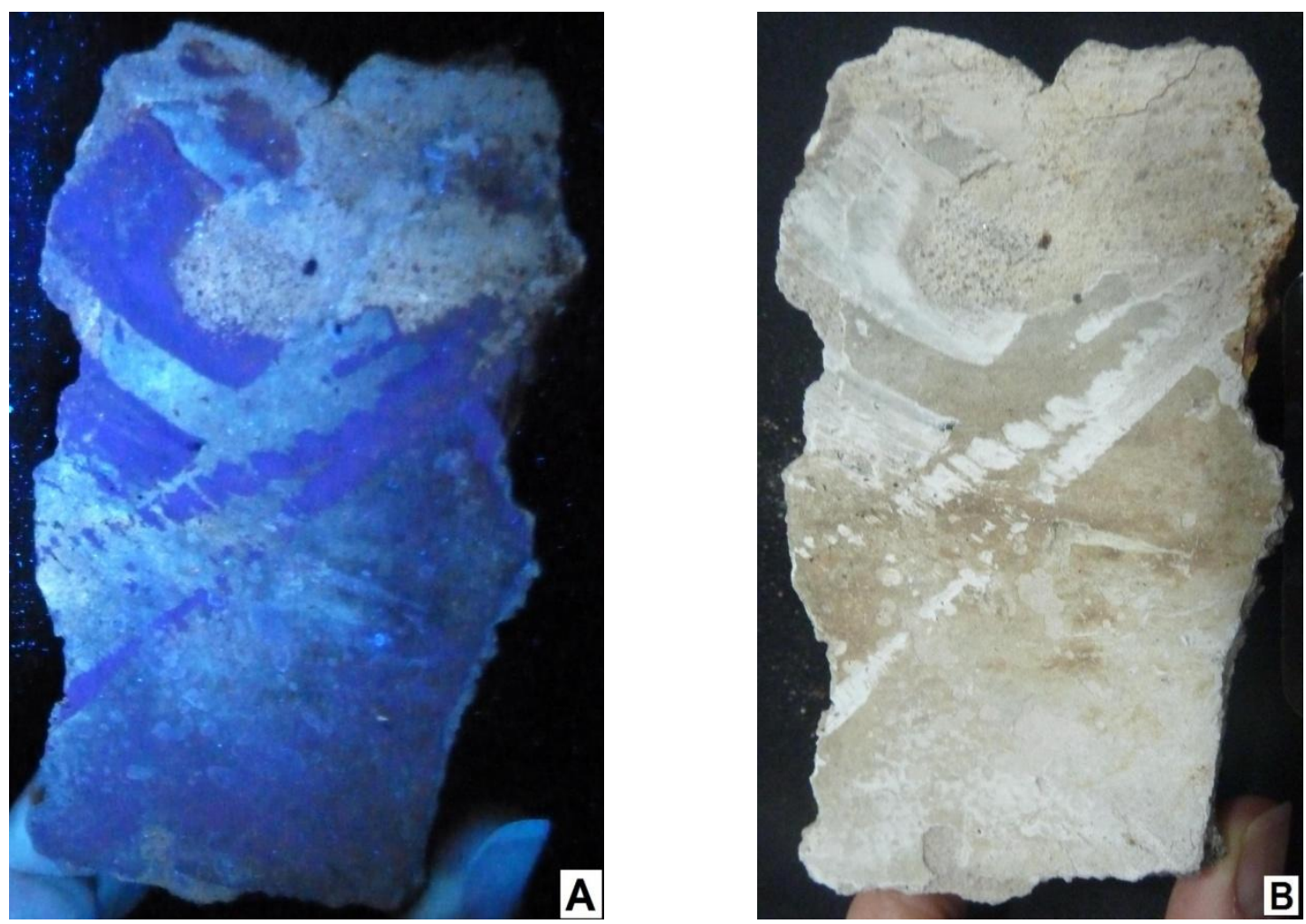

Figura 52A: Amostra 02 iluminada por lanterna UV; 52 $\mathrm{B}$ : Amostra 02 sob iluminação ambiente para comparação. 


\subsubsection{CONCLUSÕES SOBRE A AMOSTRA 02}

Os resultados das análises sobre os materiais componentes da amostra 02 levam à conclusão de que se trata de trecho da parede constituído durante reforma feita no local, posterior à confecção do mural, não sendo portanto parte do trabalho do artista.

Por cima de um conduíte plástico, foi aplicada argamassa de cor cinza e dureza alta, tendo como aglomerante cimento Portland, confirmado pela identificação de restos de clínquer na descrição petrográfica. Sobreposta a esta, há uma camada de argamassa que também possui, embora em menor quantidade, restos de clínquer de cimento Portland, mas, por possuir cor clara e dureza baixa, conclui-se que se trata de argamassa contendo mistura de cimento Portland com cal e/ou argilas.

As camadas superficiais foram interpretadas como: massa industrializada para acabamento de paredes, sobreposta por duas demãos de tinta industrializada para paredes.

Vale citar que o mural foi executado no ano de 1954, e nesta década ainda não eram comuns mercadorias de material plástico no Brasil, como por exemplo conduítes tal qual o encontrado no interior da camada mais profunda desta amostra (Donato, 1972), assim como não era comum a comercialização de produtos com a diversidade que aparecem aqui - duas qualidades diferentes de tintas industrializadas, sobrepostas a uma camada de massa industrializada para acabamento de paredes. 


\subsection{AMOSTRA 03}

\subsubsection{DESCRIÇÃO MACROSCÓPICA}

A amostra 03 possui superfície rugosa de cor cinza, com marcas de danos pelo incêndio (Figura 53). Segundo a tabela Rock-Color Chart (ROCK-COLOR CHART COMMITTEE, 1963), a cor que mais se aproxima da cor cinza da superfície desta amostra é a "Medium light gray N 6".

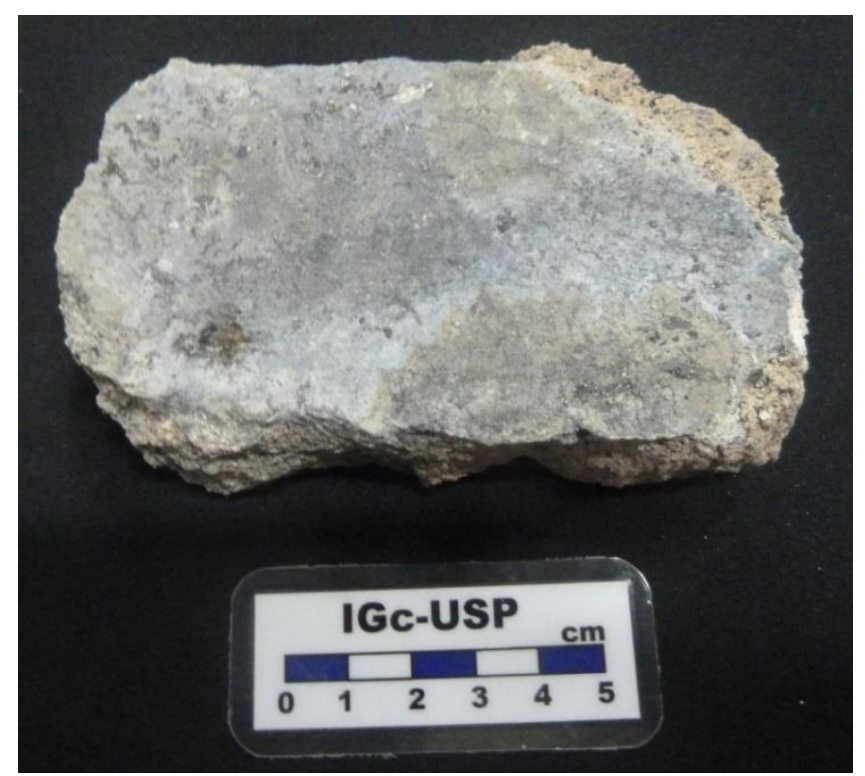

Figura 53: Amostra 03.

No corte estratigráfico da amostra 03 (Figura 54 ) é possível distinguir a olho nu três camadas. Na Figura $54_{\mathrm{B}}$, os tracejados indicam os contatos entre elas. A camada 'II' é submilimétrica, de cor cinza. A camada ' $l$ ' tem espessura aproximada de $5 \mathrm{~mm}$, aglomerante de cor cinza claro e agregados subangulosos, medianamente esféricos, com granulometria de areia fina a média. A camada ' 0 ' tem aglomerante de cor rosa claro, agregados angulosos, de baixa esfericidade e mal selecionados, de areia fina a seixo (grãos de até $7 \mathrm{~mm}$ ). Sua espessura não pode ser determinada pois a quebra da amostra não possibilita visualizar contato com outro material. 

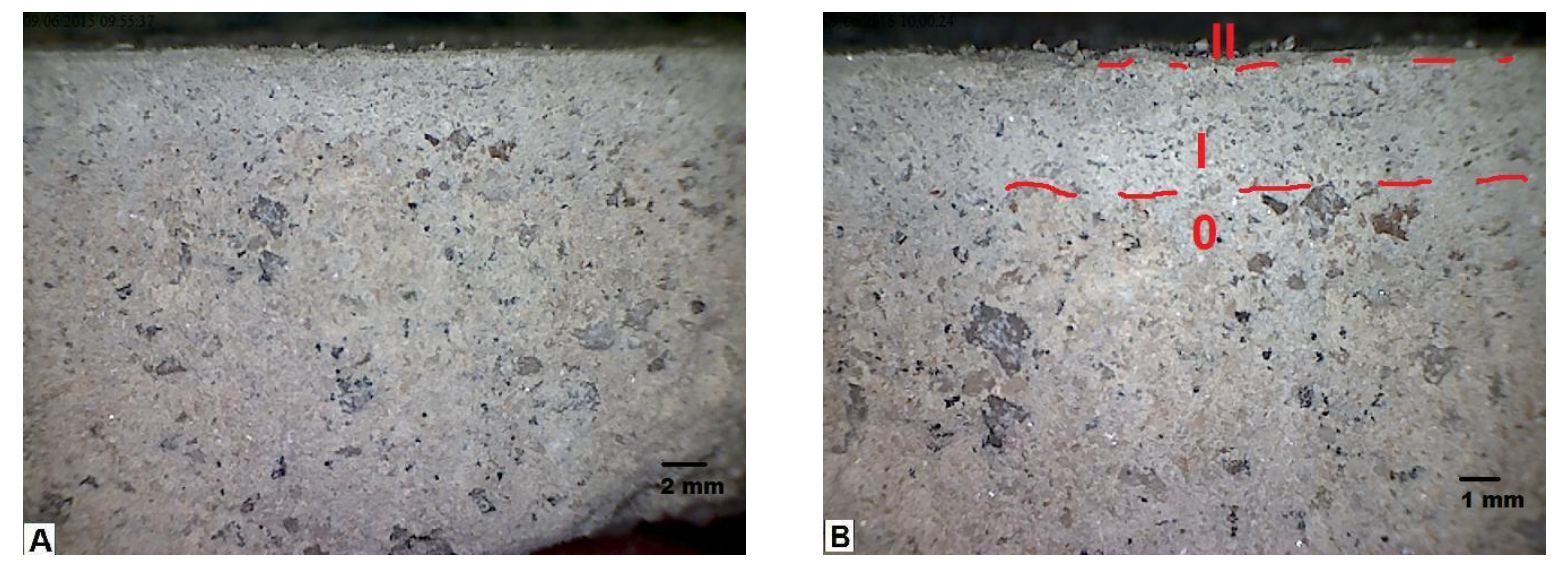

Figura 54A: Corte estratigráfico da amostra 03. 54 $\mathrm{B}$ : Tracejados indicam os contatos entre as três camadas visíveis a olho nu. 


\subsubsection{DESCRIÇÃO PETROGRÁFICA}

No microscópio petrográfico é possível distinguir uma quarta camada, denominada ' $P$ ' (Figuras $55_{\mathrm{A}}$ e $55_{\mathrm{B}}$ ). É composta de material argiloso com aspecto de lama carbonática (e possui agregados muito finos, visíveis somente nas imagens feitas no MEV (Figura 58 em diante). A camada 'Il' é composta também de material argiloso com aspecto de lama carbonática, e raros grãos minerais muito finos. A camada ' ' possui agregados subangulosos de média esfericidade, granulometria aproximada de 50 a $500 \mu \mathrm{m}$, sendo cerca de $80 \%$ de grãos de quartzo, o restante feldspatos e micas, envolvidos por matriz argilosa.

As Figuras $56_{\mathrm{A}}$ e $56_{\mathrm{B}}$ mostram o contato entre as camadas ' 0 ' e ' $l$ '. A camada ' 0 ' possui agregados angulosos de baixa esfericidade, de granulometria média estimada visualmente entre $100 \mu \mathrm{m}$ e $3 \mathrm{~mm}$, envolvidos por matriz argilosa.
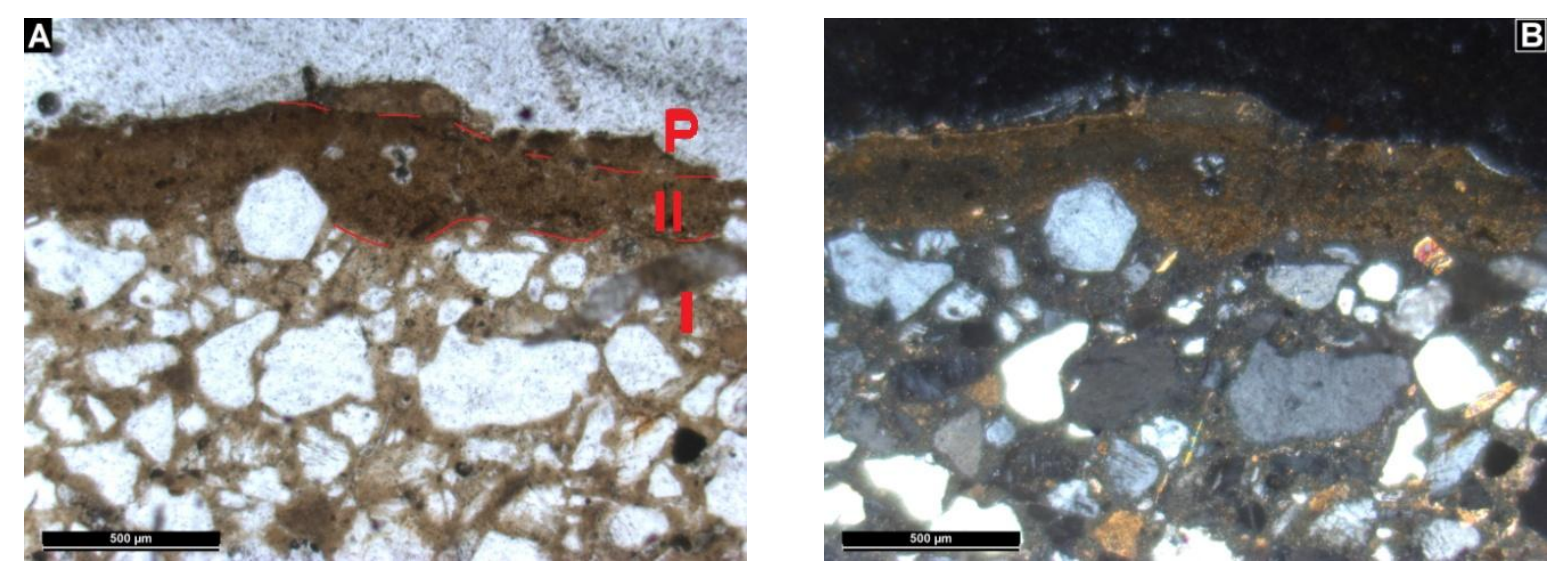

Figura 55: Fotomicrografia da amostra 03. Tracejados indicam os contatos entre as diferentes camadas. A: Polarizadores paralelos. B: Polarizadores cruzados.
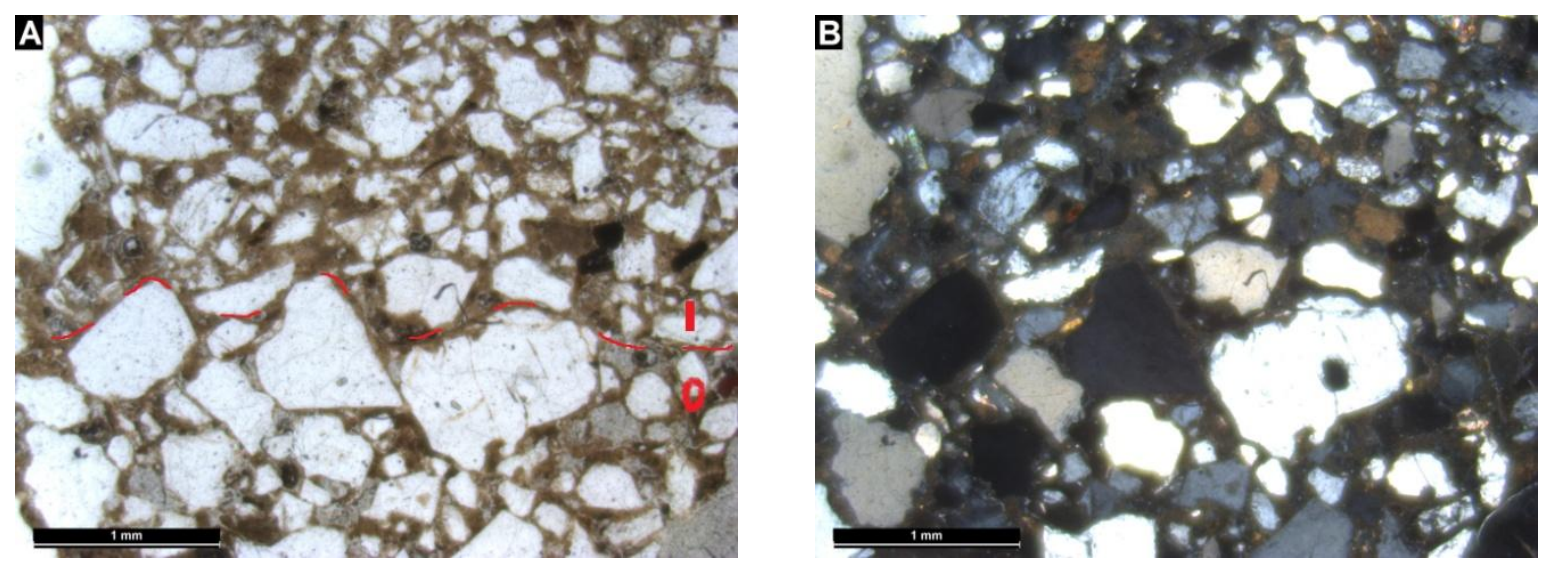

Figura 56: Fotomicrografia da amostra 03 , contato entre as camadas ' 0 ' e ' $l$ '. A: Polarizadores paralelos. B: Polarizadores cruzados. 


\subsection{3a MEV/EDS - CORTE ESTRATIGRÁFICO}

A Figura $57_{A}$ mostra o fragmento da amostra 03 embutido em resina e a Figura $57_{B}$ mostra parte da área da amostra que foi analisada no MEV.
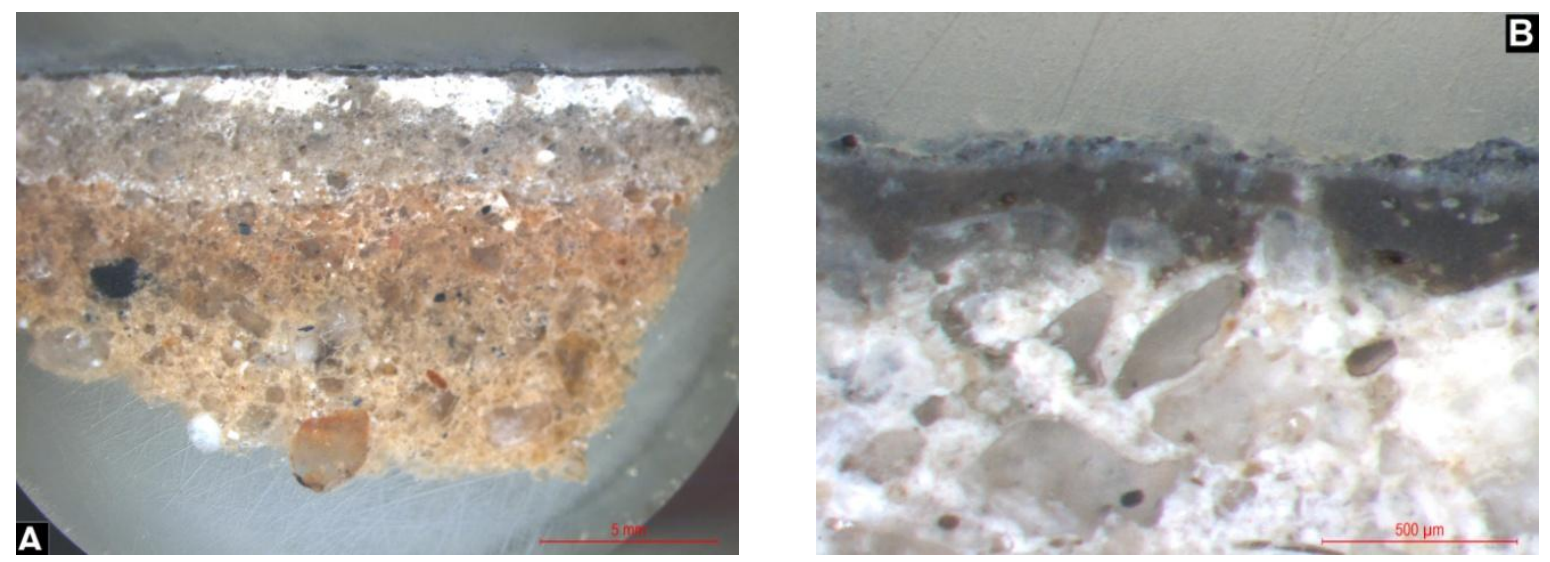

Figura 57 : Fragmento da amostra 03 embutido em resina para ser analisado em MEV/EDS. 57B: Detalhe deste fragmento enfocando as camadas superficiais.

Não faz parte dos objetivos das análises em MEV/EDS a caracterização das camadas profundas: o enfoque é na camada pictórica, e, quando se trata da técnica do mezzo fresco, na camada pictórica e em sua relação com a camada preparatória subjacente. Por esse motivo, a camada ' 0 ' desta amostra não foi alvo das análises.

A primeira área submetida a mapeamento composicional por EDS está nas Figuras $58_{A}$ e $59_{A}$. Esta imagem foi repetida para que se possa perceber com mais clareza as porções enriquecidas em cálcio e em magnésio. Observando as Figuras $58_{\mathrm{B}} \mathrm{e}$ $59_{\mathrm{B}}$ é possível concluir que a camada 'l' foi feita com aglomerante de cal composta tanto por cálcio quanto por magnésio; a camada 'll' foi feita com aglomerante de cal rica em cálcio; e a camada ' $P$ ' com aglomerante contendo apenas magnésio - o cálcio nesta camada está presente somente em grãos do agregado, como visto em detalhe na segunda área analisada no MEV desta amostra 03 (Figura 63 ${ }_{\mathrm{A}}$ ).

Os mapas dos elementos $\mathrm{Si}$, Al e K (Figuras $60_{\mathrm{A}}, 60_{\mathrm{B}}$ e 61 ) confirmam a mineralogia diversa do agregado usado na camada 'l', com grãos de quartzo, feldspatos e micas.

Foram feitos também mapeamentos composicionais para os elementos $\mathrm{Fe}, \mathrm{Na}, \mathrm{P}, \mathrm{S}$ e Ti, mas não apresentaram distribuição nos mapas. 

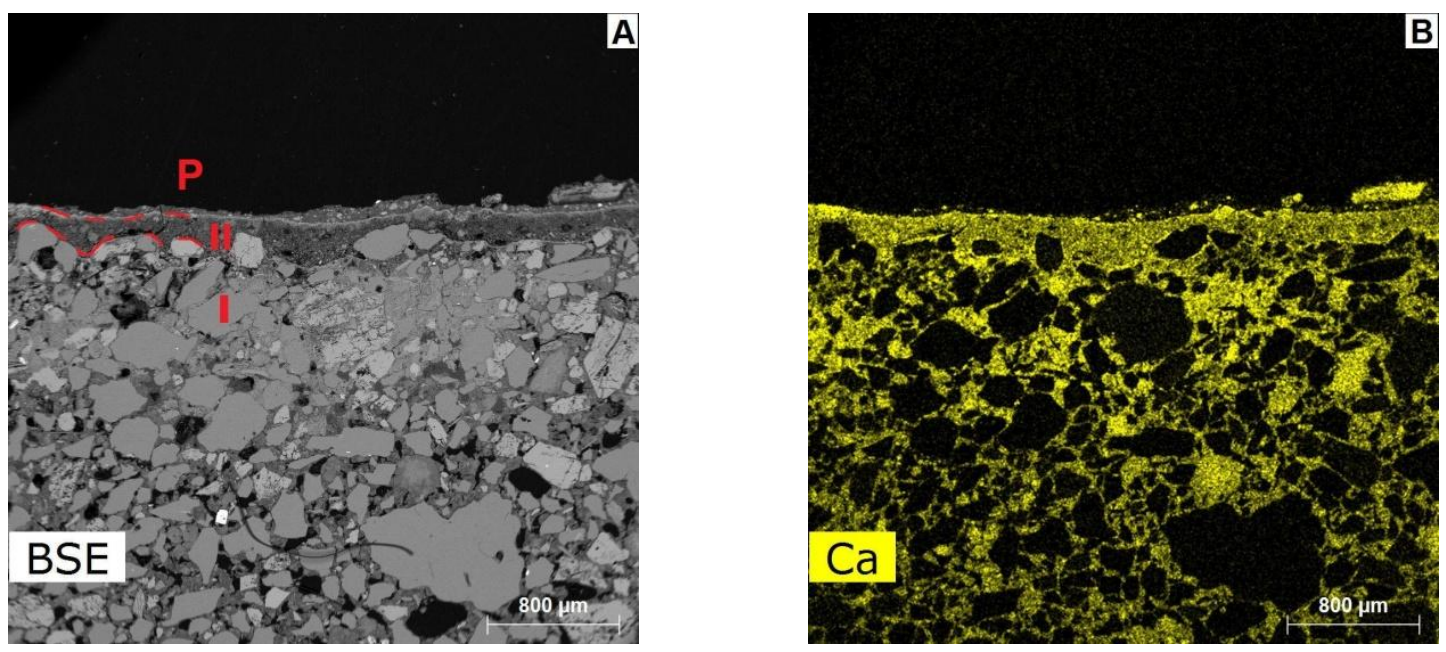

Figura 58A: Primeira área da amostra 03 analisada em MEV. Imagem de elétrons retroespalhados. Tracejados indicam os contatos entre as diferentes camadas. $58_{\mathrm{B}}$ : Mapeamento por EDS do elemento $\mathrm{Ca}$.
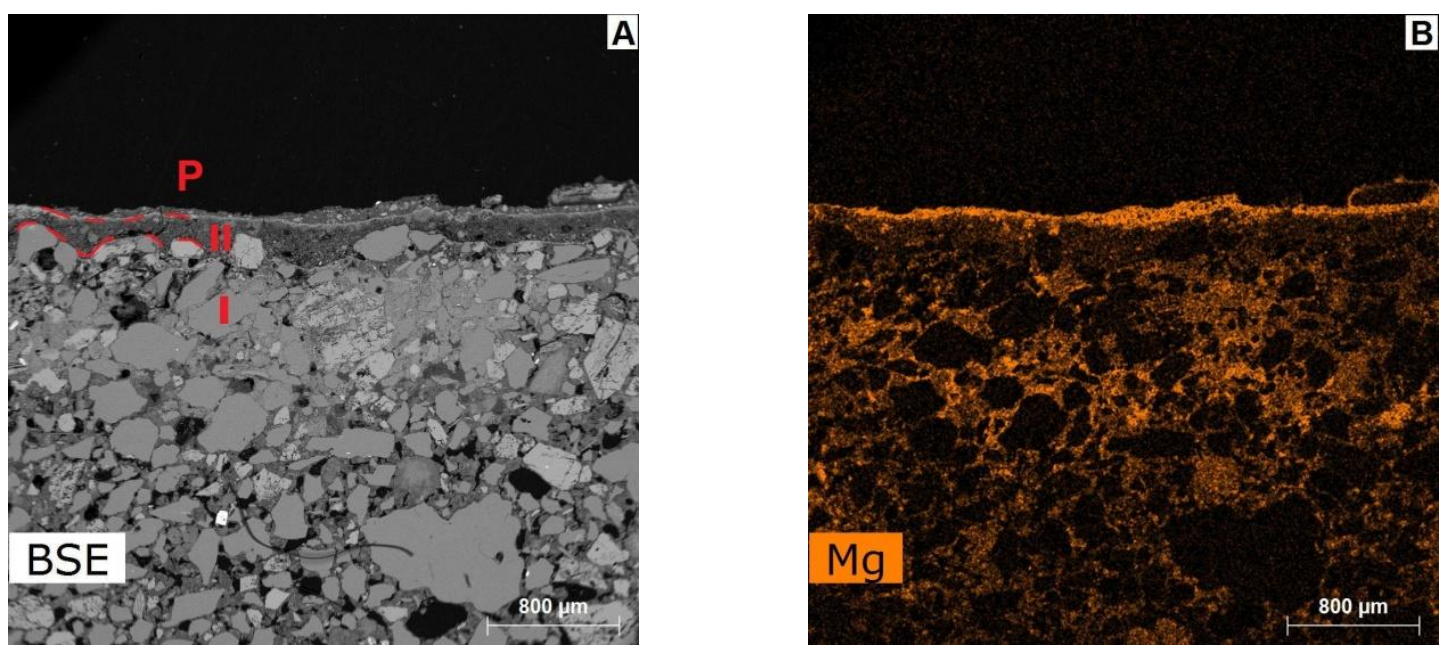

Figura 59 $\mathrm{A}$ : Primeira área da amostra 03 analisada em MEV. Imagem de elétrons retroespalhados. Tracejados indicam os contatos entre as diferentes camadas. $59_{\mathrm{B}}$ : Mapeamento por EDS do elemento Mg.
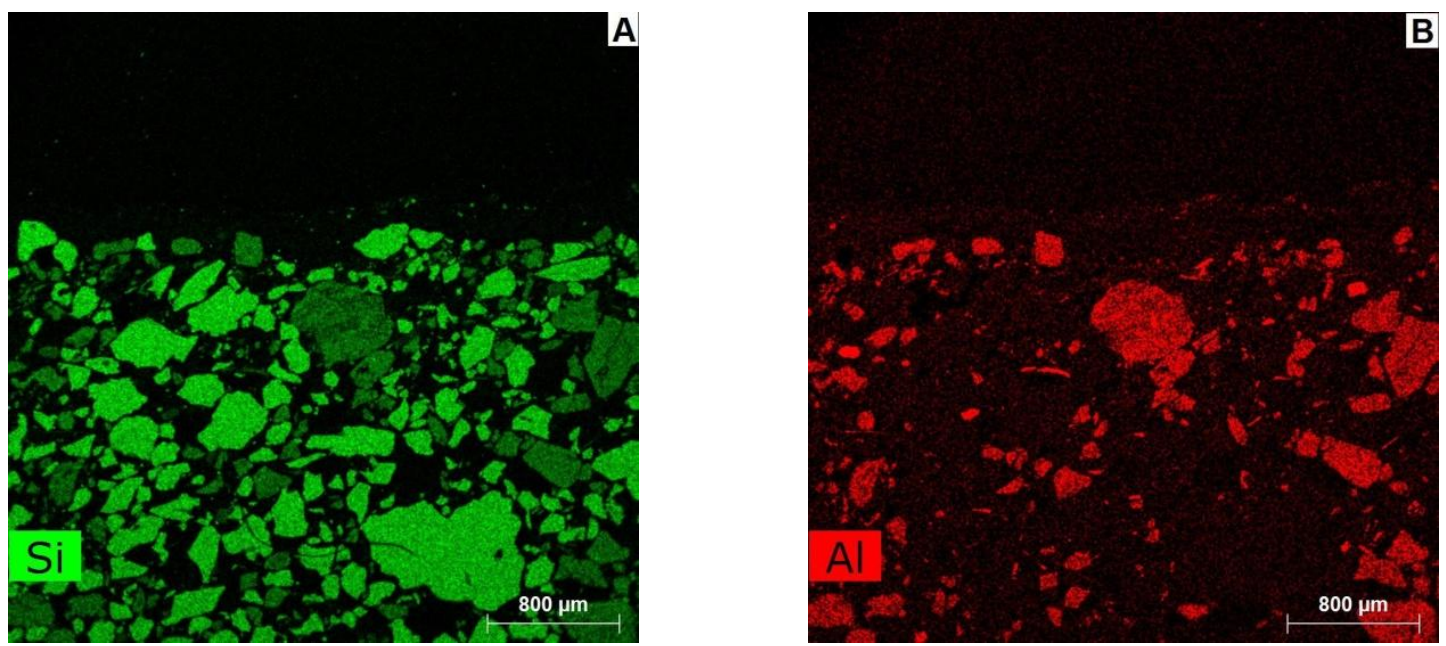

Figura 60: Mapeamentos composicionais por EDS na primeira área analisada da amostra 03. A: Mapeamento do elemento Si; B: Mapeamento do elemento Al. 


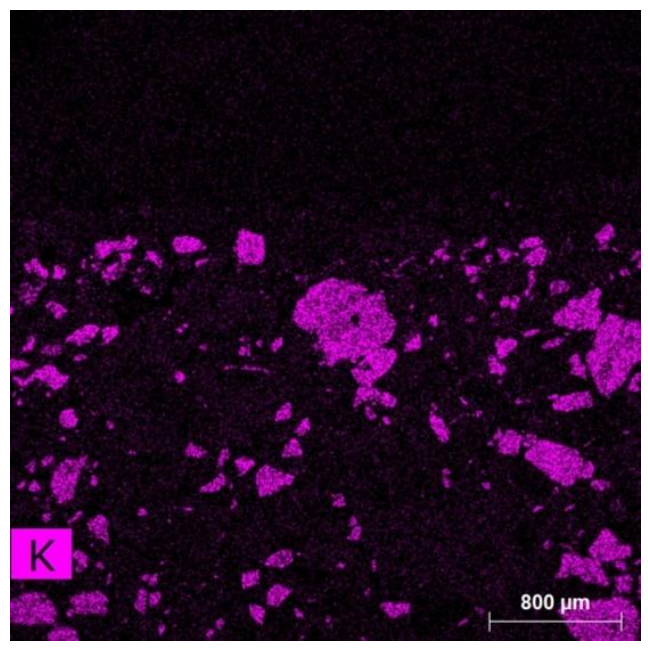

Figura 61: Mapeamento composicional do elemento K, na primeira área analisada da amostra 03.

A Figura $62_{\mathrm{A}}$ mostra a segunda área da amostra 03 analisada no $\mathrm{MEV}$, enfocando as camadas superficiais. Na Figura $63_{\mathrm{A}}$ é possível ver com clareza a película rica em cálcio formada entre as camadas 'Il' e 'l', consequência do fato da superfície desta última já estar em adiantado estado de carbonatação - portanto seca ou semisseca quando a camada 'Il' foi aplicada.

As Figuras $62_{B}$ e 63 ${ }_{A}$ mostram que na interface entre as camadas 'Il' e ' $P$ ' existe também uma película, resultado de processo de carbonatação. Nota-se, no entanto, que existe uma interação entre os materiais da camada ' $P$ ' e da camada subjacente. $\mathrm{Na}$ Figura $62_{\mathrm{B}}$ é possível ver essa interação: o material da camada ' $\mathrm{P}$ ' penetra nos micrômetros superficiais da camada 'Il'. Portanto conclui-se que, quando o artista aplicou a camada 'P', a camada subjacente estava já em processo de carbonatação, mas ainda continha quantidade significativa de umidade.

As Figuras $63_{\mathrm{A}}, 63_{\mathrm{B}}$ e $64_{\mathrm{A}}$ mostram a composição de grãos muito finos como agregados na camada ' $P$ ', com maioria de grãos ricos em cálcio - grãos de calcita ou fragmentos de lama carbonática, entre outros grãos principalmente contendo Si e Al. 

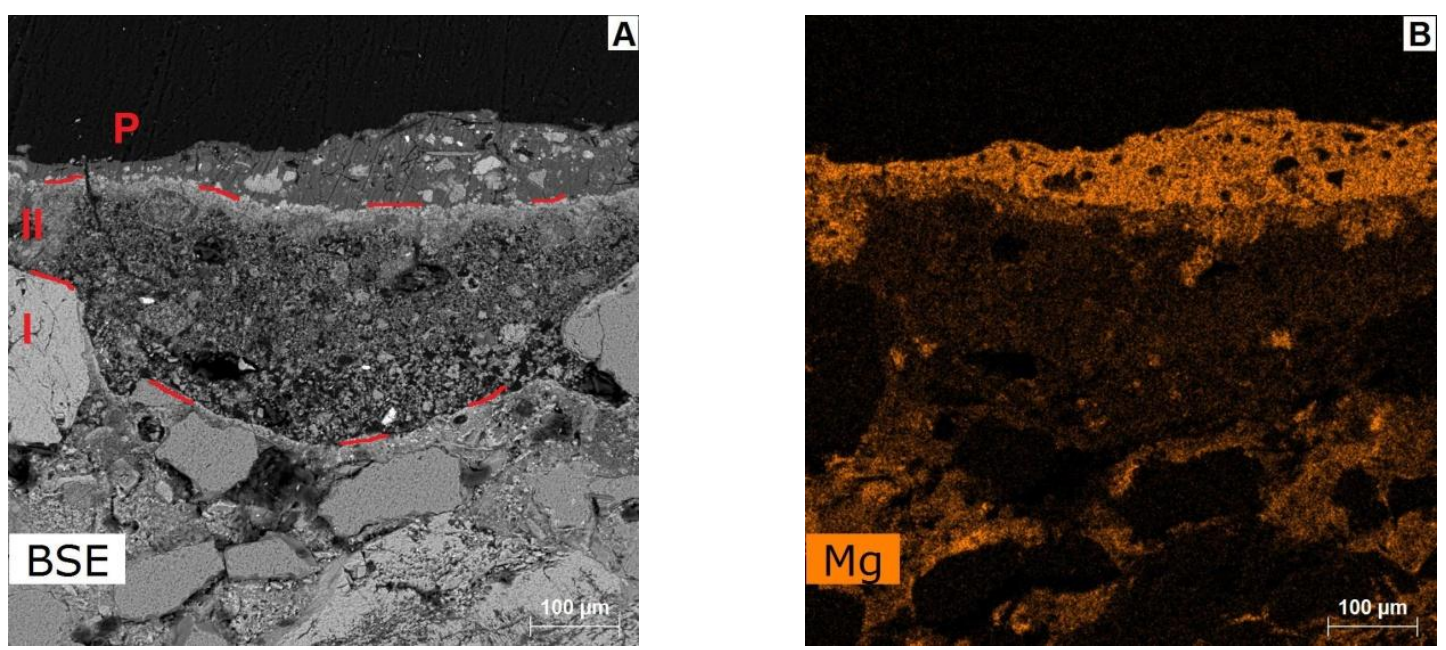

Figura 62A: Segunda área da amostra 03 analisada em MEV. Imagem de elétrons retroespalhados. Tracejados indicam os contatos entre as diferentes camadas. $62_{\mathrm{B}}$ : Mapeamento por EDS do elemento Mg.
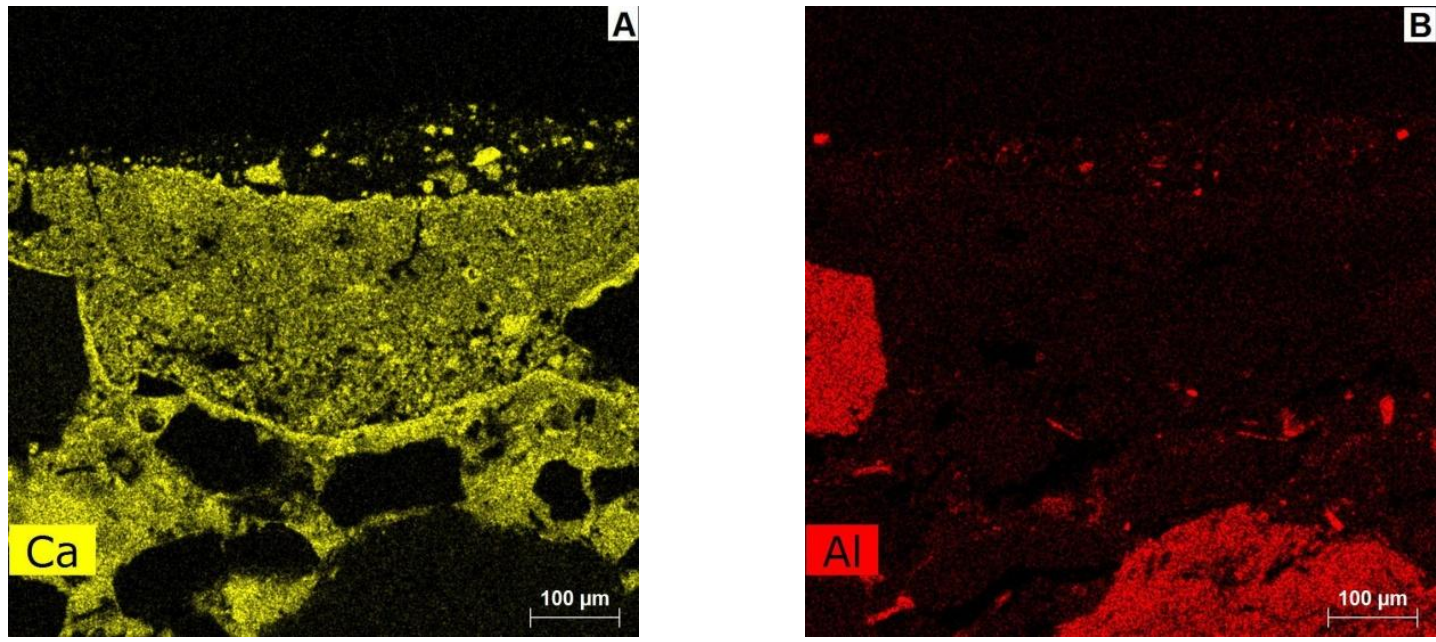

Figura 63: Mapeamentos composicionais por EDS na segunda área analisada da amostra 03. A: Mapeamento do elemento Ca; B: Mapeamento do elemento Al.
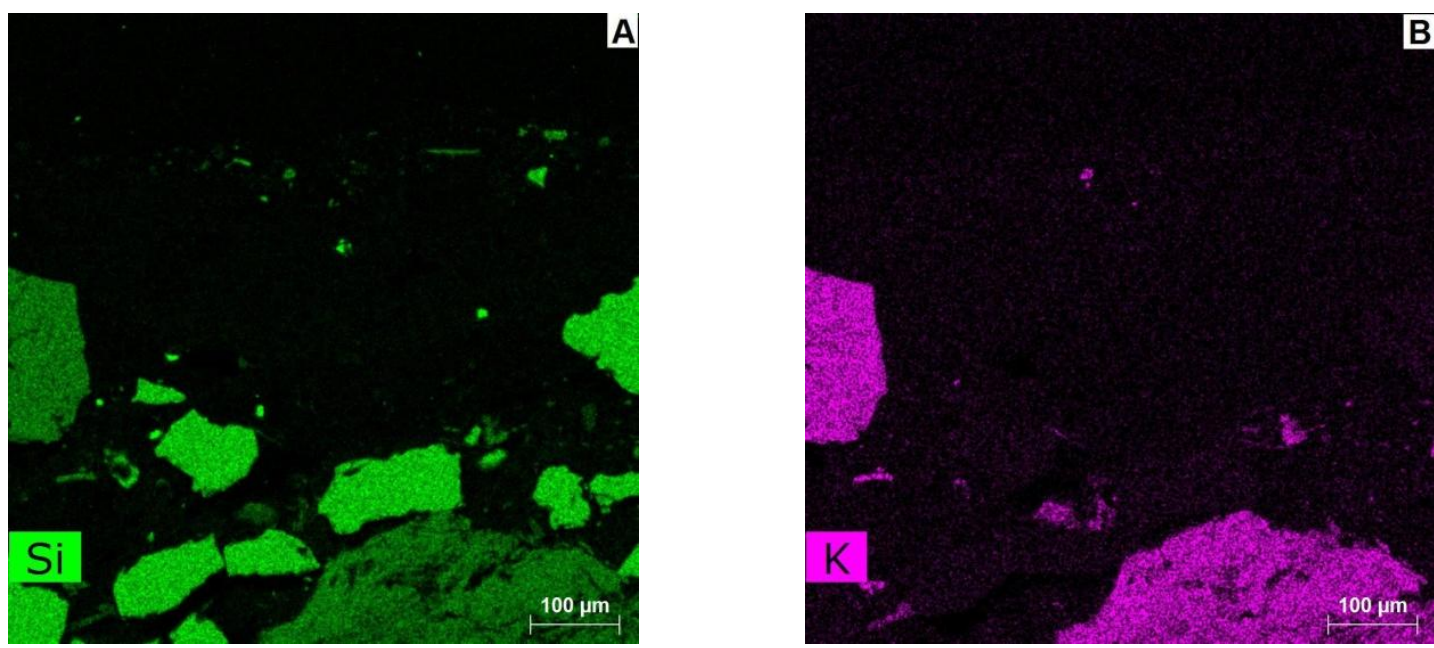

Figura 64: Mapeamentos composicionais por EDS na segunda área analisada da amostra 03. A: Mapeamento do elemento Si; B: Mapeamento do elemento K. 
As Figuras 65 e 66 mostram a composição magnesiana do aglomerante da camada $\mathrm{P}$, através de espectro composicional feito por EDS em uma região com pouca presença de agregados - esses estão representados pelas pequenas quantidades de Si e Ca neste espectro. Por apresentar apenas o elemento Mg, pode-se concluir que o aglomerante desta camada é composto de magnesita.

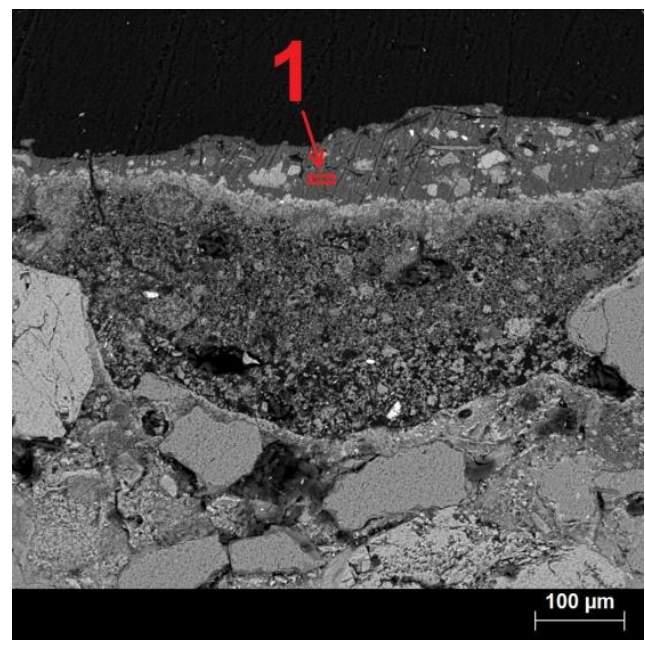

Figura 65: Área, na camada pictórica da amostra 03, de onde foi lido espectro composicional por EDS.

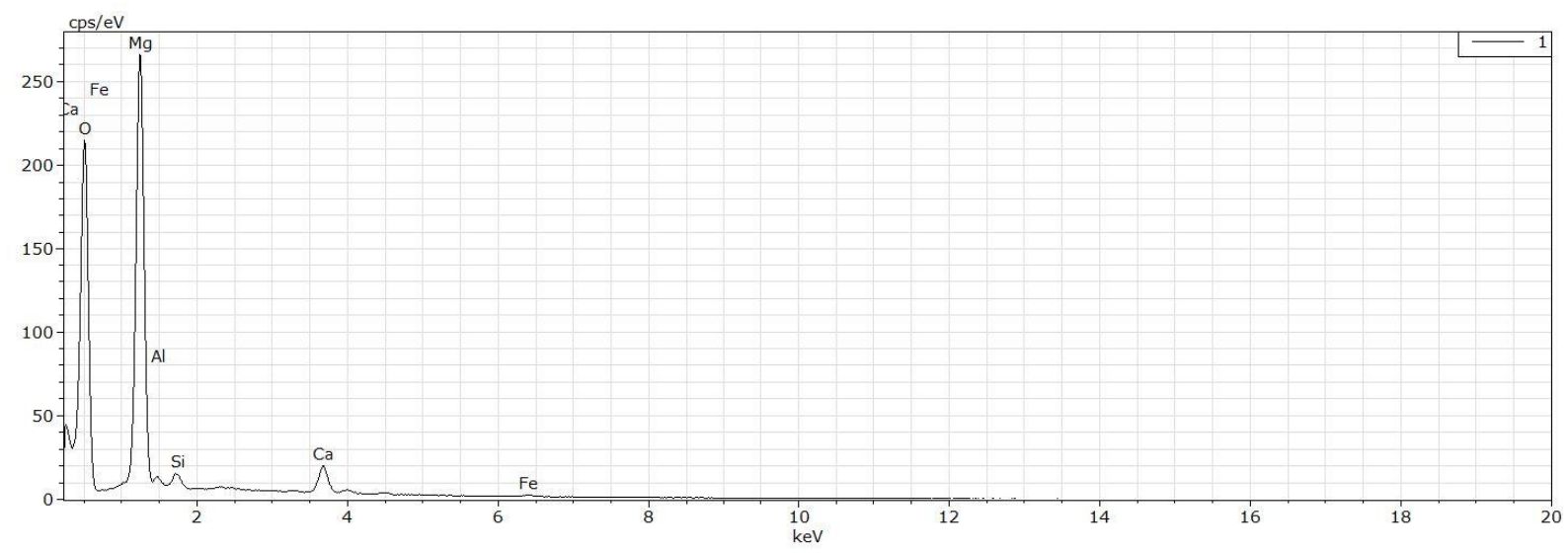

Figura 66: Espectro composicional por EDS da área '1', dentro da camada pictórica da amostra 03, marcada na Figura 65. 


\subsection{3b MEV/EDS - SUPERFÍCIE PICTÓRICA}

Na Figura 67 destaca-se o fragmento da superfície da amostra 03 analisado no MEV. A Figura $68_{A}$ mostra que, quando comparada com as superfícies das amostras 01 e 05 (Figuras 28 e 108) - rugosas, compostas principalmente de carbonato de cálcio (calcita) -, a superfície da amostra 03 - composta principalmente de carbonato de magnésio (magnesita) - apresenta baixa rugosidade.

$\mathrm{Na}$ Figura $68_{\mathrm{B}}$ verifica-se a presença de fibras, técnica esta de uso comum, com o intuito de reforçar a argamassa.

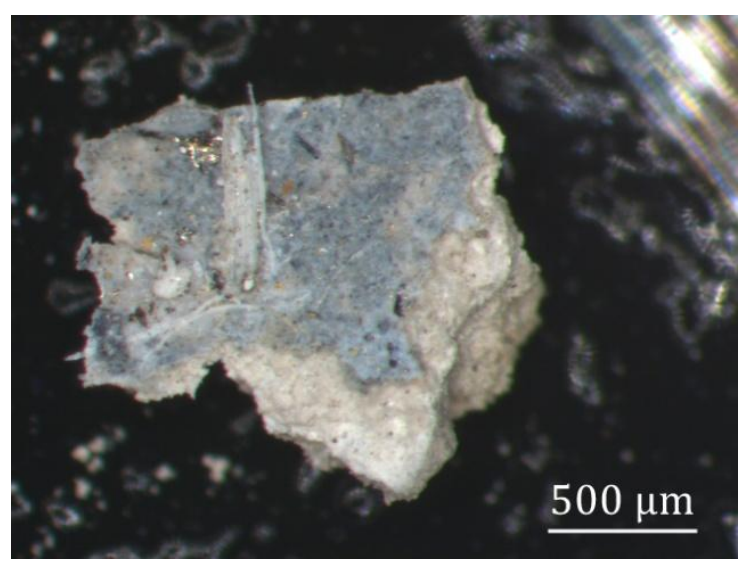

Figura 67: Fragmento da superfície da amostra 3 analisado em MEV, com a presença de fibras misturadas à argamassa.
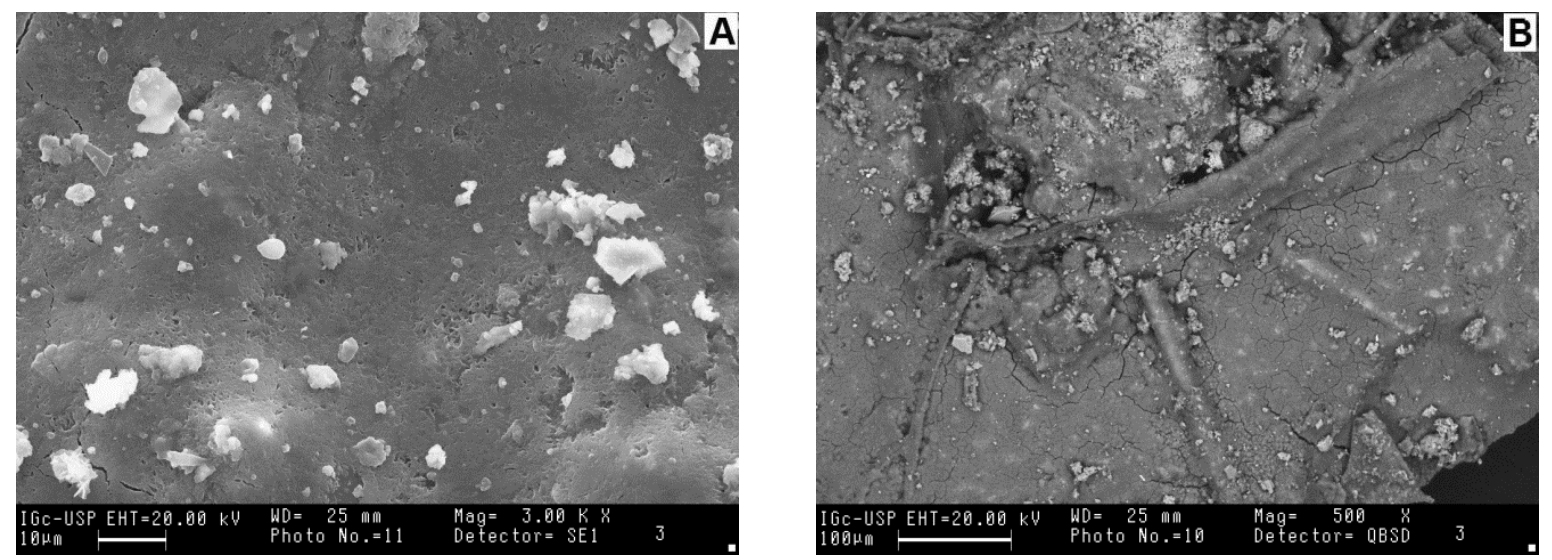

Figura $68_{\mathrm{A}}$ : Imagem de superfície da amostra 03 , elétrons secundários. $68_{\mathrm{B}}$ : imagem de superfície da amostra $03 \mathrm{com}$ a presença de fibras na argamassa. 


\subsubsection{FLUORESCÊNCIA DE RAIOS X}

$\mathrm{Na}$ Tabela 3 foram realçados em vermelho os elementos que apresentaram quantidades elevadas no resultado da análise por FRX semiquantitativa de varredura superficial da amostra 03 . Ca e Mg destacam-se pois são os principais elementos da camada pictórica ( $\mathrm{Mg}$ como aglomerante e Ca como agregado). Al e Si também figuram como agregados desta camada, em menor quantidade.

Tabela 3: Dados semiquantitativos (\%) de espectrometria de fluorescência de raios $X$ de varredura superficial, de todas as amostras para comparação.

\begin{tabular}{|c|c|c|c|c|c|}
\hline AMOSTRA & 01 & 02 & 03 & 04 & 05 \\
\hline Sum sem norm & 75,7 & 88,8 & 67,3 & 82,7 & 66,4 \\
\hline $\mathrm{Na}_{2} \mathrm{O}$ & 0,14 & 0,096 & 0,111 & 0,073 & 0,118 \\
\hline $\mathrm{MgO}$ & 5,177 & 4,533 & 47,342 & 4,902 & 9,187 \\
\hline $\mathrm{Al}_{2} \mathrm{O}_{3}$ & 3,662 & 4,341 & 3,478 & 6,188 & 6,812 \\
\hline $\mathrm{SiO}_{2}$ & 7,908 & 7,484 & 4,827 & 11,623 & 17,706 \\
\hline $\mathrm{P}_{2} \mathrm{O}_{5}$ & 0,094 & 0,291 & 0,091 & 0,184 & 0,263 \\
\hline $\mathrm{SO}_{3}$ & 5,834 & 1,179 & 0,517 & 0,828 & 2,105 \\
\hline $\mathrm{Cl}$ & 0,39 & 0,265 & 0,228 & 0,301 & 0,299 \\
\hline $\mathrm{K}_{2} \mathrm{O}$ & 0,31 & 0,419 & 0,208 & 1,16 & 0,541 \\
\hline $\mathrm{CaO}$ & 70,313 & 46,736 & 40,688 & 43,212 & 59,214 \\
\hline $\mathrm{TiO}_{2}$ & 2,614 & 33,64 & 0,777 & 30,615 & \\
\hline $\mathrm{Cr}$ & 0,013 & 0,018 & 0,012 & 0,026 & 0,019 \\
\hline $\mathrm{MnO}$ & 0,078 & 0,035 & 0,044 & 0,007 & \\
\hline $\mathrm{Fe}_{2} \mathrm{O}_{3}$ & 3,228 & 0,638 & 1,335 & 0,482 & 2,43 \\
\hline $\mathrm{Ni}$ & 0,004 & 0,005 & 0,007 & 0,005 & 0,006 \\
\hline $\mathrm{Cu}$ & 0,018 & 0,018 & 0,037 & 0,01 & 0,022 \\
\hline $\mathrm{Zn}$ & 0,037 & 0,076 & 0,091 & 0,023 & 0,138 \\
\hline $\mathrm{Rb}$ & 0,005 & 0,007 & 0,009 & 0,007 & 0,006 \\
\hline $\mathrm{Sr}$ & 0,105 & 0,089 & 0,021 & 0,043 & 0,059 \\
\hline $\mathrm{Y}$ & 0,003 & 0,002 & 0,004 & 0,002 & 0,002 \\
\hline $\mathrm{Zr}$ & 0,033 & 0,031 & 0,038 & 0,019 & 0,027 \\
\hline $\mathrm{Ba}$ & 0,031 & 0,07 & 0,122 & 0,053 & 0,104 \\
\hline $\mathrm{Pb}$ & 0,004 & 0,019 & 0,011 & 0,011 & 0,015 \\
\hline $\mathrm{Br}$ & & & & & 0,002 \\
\hline $\mathrm{Ce}$ & & & & & 0,102 \\
\hline Co & & & & & 0,138 \\
\hline $\mathrm{F}$ & & & & 0,219 & 0,289 \\
\hline $\mathrm{Ga}$ & & 0,002 & & & \\
\hline $\mathrm{Mn}$ & & & & & 0,097 \\
\hline $\mathrm{Nb}$ & & 0,007 & & 0,008 & \\
\hline $\mathrm{Ti}$ & & & & & 0,298 \\
\hline
\end{tabular}




\subsubsection{LANTERNA UV}

Na Figura $69_{A}$, o tracejado indica a área da amostra que recebeu a radiação UV. Como se pode ver (e usando a Figura $69_{B}$ para comparação) as regiões da superfície da amostra 03 que não apresentam danos pelo incêndio, quando expostas à radiação UV, emitem luz de maneira heterogênea, predominando os azuis mais ou menos claros. As porções onde houve danos pelo incêndio - visíveis principalmente nas regiões inferior direita e inferior esquerda - não emitem radiação, permanecendo escuras.
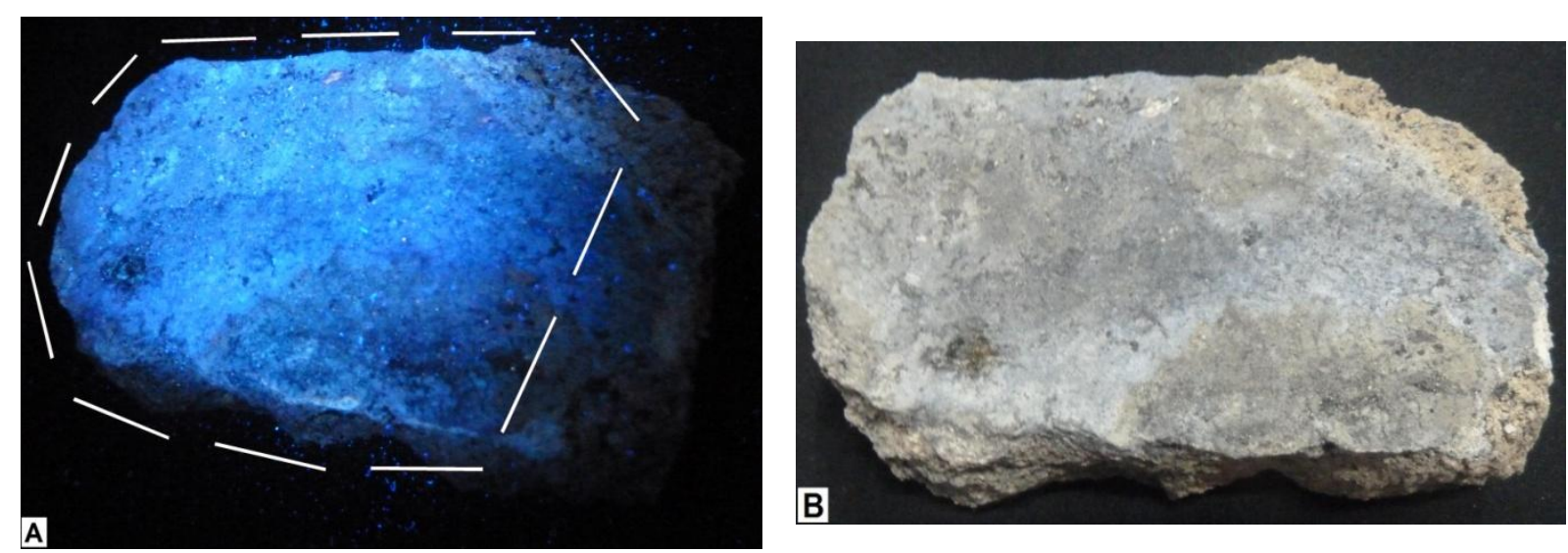

Figura $69_{\mathrm{A}}$ : $\mathrm{O}$ tracejado indica a área da amostra 03 iluminada por lanterna UV; $69_{\mathrm{B}}$ : Amostra 03 sob iluminação ambiente para comparação. 


\subsubsection{CONCLUSÕES SOBRE A AMOSTRA 03}

A superfície da amostra 03 apresenta cor cinza. Apesar de não terem sido identificados pigmentos através das caracterizações elementares, a camada externa denominada ' $\mathrm{P}$ ' é interpretada como camada pictórica, elaborada com argamassa composta de materiais que resultam em sua cor cinza. Neste caso mais uma vez o artista não usou a técnica tradicional do afresco (buon fresco).

Após a aplicação da camada preparatória 'l', composta de argamassa de cal, estando a superfície desta última já seca ou semisseca (com uma película carbonatada já formada), o artista aplicou primeiramente uma demão de cal, aqui chamada de camada 'Il' (cal rica em cálcio, sem agregados) que ainda continha certa umidade quando foi aplicada a camada pictórica ('P'), de composição magnesiana contendo agregados muito finos e cor cinza.

Mais uma vez, assim como ocorre na amostra 01, vemos a utilização de uma variação do método chamado mezzo fresco (que consiste na aplicação de água de cal já pigmentada, sobre a camada de argamassa em adiantado estado de carbonatação (Cennini, 1398; Tirello, 2001; Tirello, 2006; Del Lama et al., 2009). No caso desta amostra, a camada de argamassa estava em adiantado estado de carbonatação, mas antes de aplicar o material pigmentado, o artista aplicou uma demão de cal (camada 'Il'), que dispôs de tempo para iniciar seu processo de carbonatação mas continha ainda umidade quando o material pigmentado foi aplicado, pois porções deste último penetraram nos micrômetros superficiais da subjacente.

A camada mais profunda - camada '0', foi descrita apenas macroscopicamente e petrograficamente, não tendo sido alvo das outras análises, pois não faz parte do escopo deste trabalho a caracterização das camadas profundas. 


\subsection{AMOSTRA 04}

\subsubsection{DESCRIÇÃO MACROSCÓPICA}

A superfície da amostra 04 (Figura 70), devido à perda de material, revela a existência de duas camadas micrométricas superficiais, a externa de cor cinza claro e a subjacente de cor branca. Estas serão denominadas $P_{0}$ e $P_{1}$.

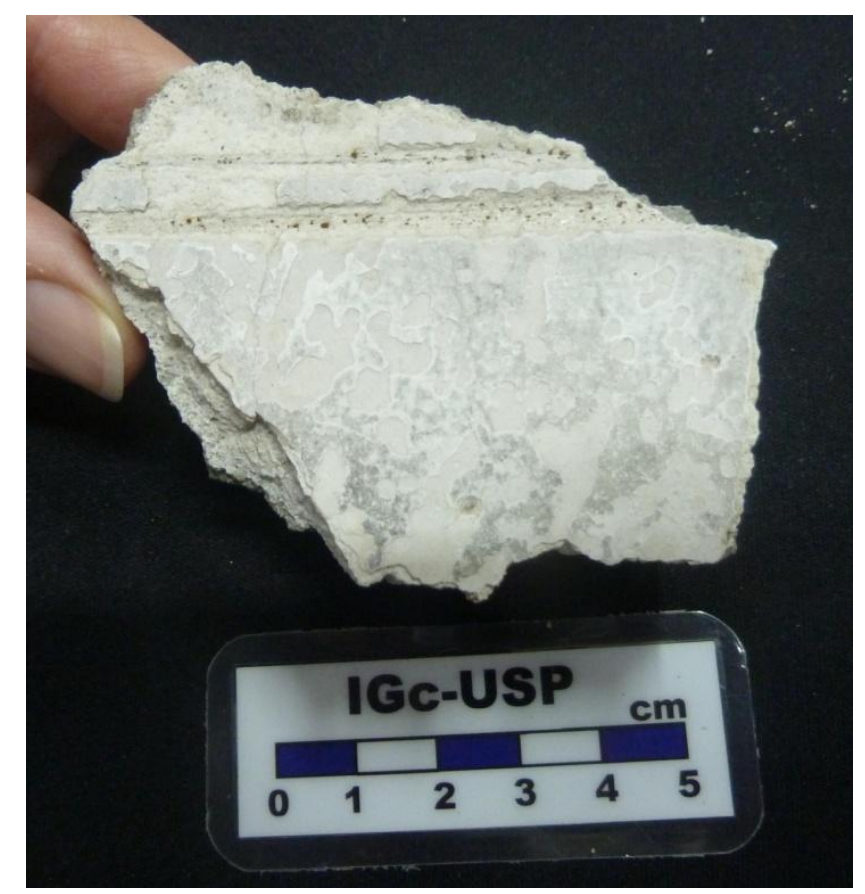

Figura 70: Amostra 04.

Individualizadas no corte estratigráfico (Figuras $71_{A}$ e $71_{B}$ ), as camadas $P_{0}$ e $P_{1}$ possuem espessura micrométrica; a camada 'Il' possui espessura irregular, desde $0,5 \mathrm{~mm}$ até $1,2 \mathrm{~mm}$ neste corte, e cor cinza claro. A camada 'l' também apresenta espessura irregular, desde menos de $1 \mathrm{~mm}$ até mais de $6 \mathrm{~mm}$. Possui aglomerante de cor branca, agregados subarredondados, de esfericidade alta e granulometria de areia fina a grossa. A camada ' 0 ' possui aglomerante cinza escuro, agregados angulosos de esfericidade baixa, com granulometria de areia fina a grânulo. A espessura desta última camada não pode ser definida, e, assim como ocorre com a amostra número 02, trata-se de argamassa aplicada durante reforma feita posteriormente à confecção da obra, pois possui em seu interior restos de um conduíte de plástico. 

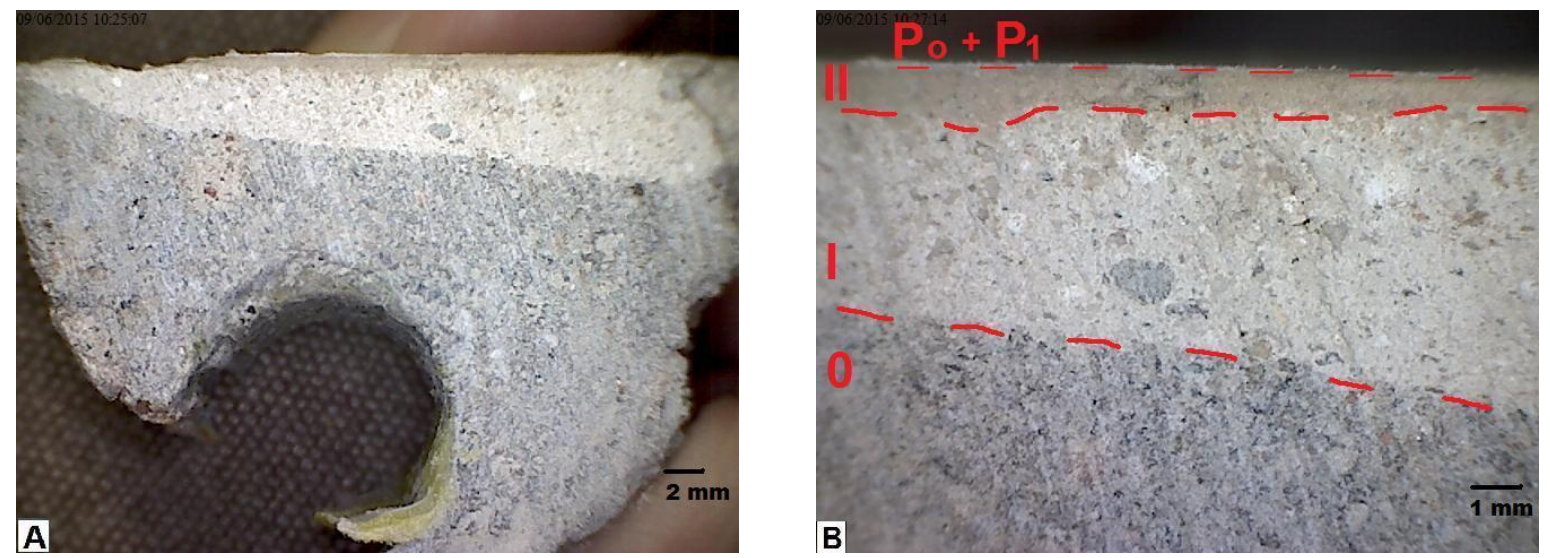

Figura $71_{\mathrm{A}}$ : Corte estratigráfico da amostra 04. 71 $\mathrm{B}$ : Tracejados indicam contatos entre camadas.

As amostras 02 e 04 possuem similaridades composicionais e estratigráficas. Assim como na amostra 02, esta amostra 04 apresenta diferença notável quanto à dureza dos aglomerantes das camadas ' 0 ' e ' $l$ ' - o da camada 'l' possui dureza baixa, riscável com a unha; o da camada ' 0 ' possui dureza mais alta, não riscável com a unha. Esta diferença também foi notada quando o material foi submetido a corte, na cortadeira de precisão (Figura $6_{\mathrm{A}}$ ), sendo a camada "I" desbastada facilmente, enquanto a camada "0" apresenta resistência significativamente maior. 


\subsubsection{DESCRIÇÃO PETROGRÁFICA}

Durante a confecção da lâmina petrográfica da amostra 04 houve perda de material e as camadas $P_{0}$ e $P_{1}$ não foram preservadas.

A camada 'Il' (Figuras 72 e 73) é formada por grãos de calcita e dolomita (as Figuras $79_{\mathrm{B}}$ e 84 confirmam a presença de magnésio além de cálcio) bem selecionados - de 10 a $20 \mu \mathrm{m}$ em média, subarredondados, de esfericidade alta, com raros grãos de outros minerais, envolvidos por material argiloso com aspecto de lama carbonática.

$\mathrm{Na}$ camada 'I' (Figuras 72 e 74), o agregado apresenta mineralogia diversa, composto na maior parte por grãos de quartzo, micas e torrões de argila, estes em quantidades aproximadamente equivalentes, e em menor quantidade grãos de feldspato, envolvidos por matriz argilosa. Os grãos são na maior parte subarredondados de esfericidade média, e granulometria desde 20 até $500 \mu \mathrm{m}$.

A camada '0' (Fgura 74) possui como aglomerante material argiloso, agregados angulosos, de esfericidade baixa, com granulometria desde $10 \mu \mathrm{m}$ até mais de 1 $\mathrm{mm}$, compostos majoritariamente por quartzo e feldspatos. 

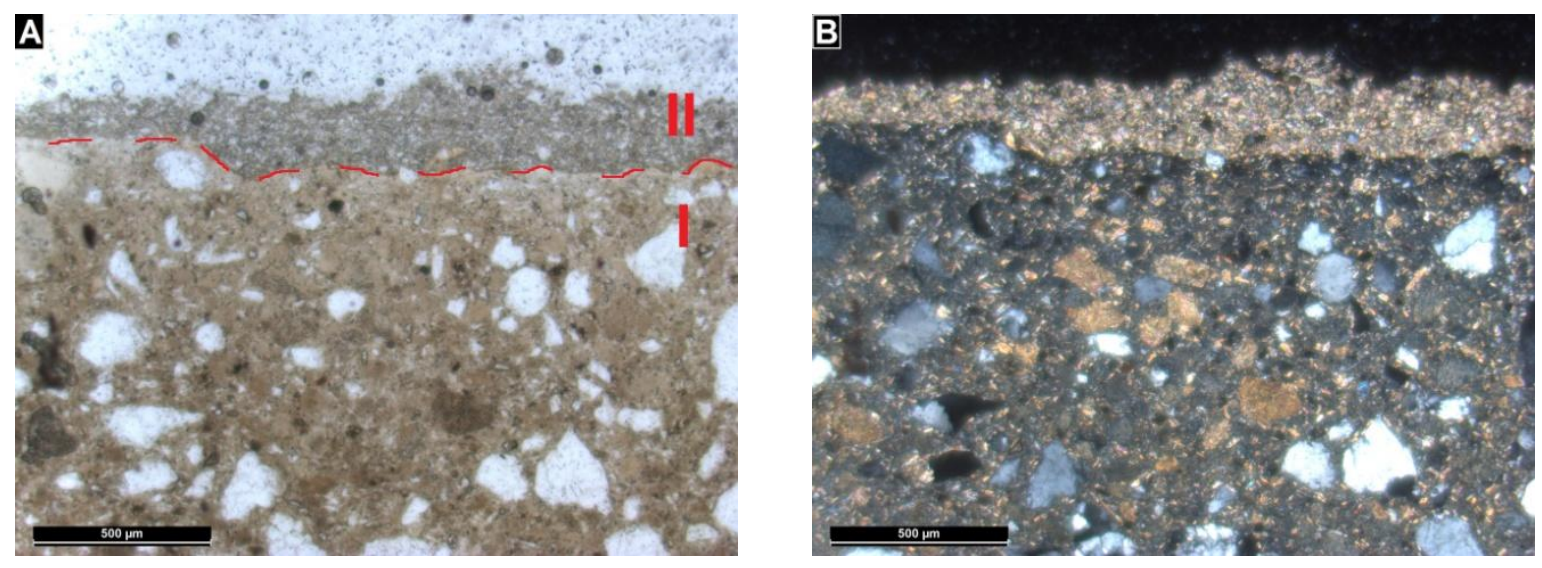

Figura 72: Fotomicrografia da amostra 04 . Tracejado indica o contato entre as camadas 'l' e 'll'. A: Polarizadores paralelos; B: Polarizadores cruzados.
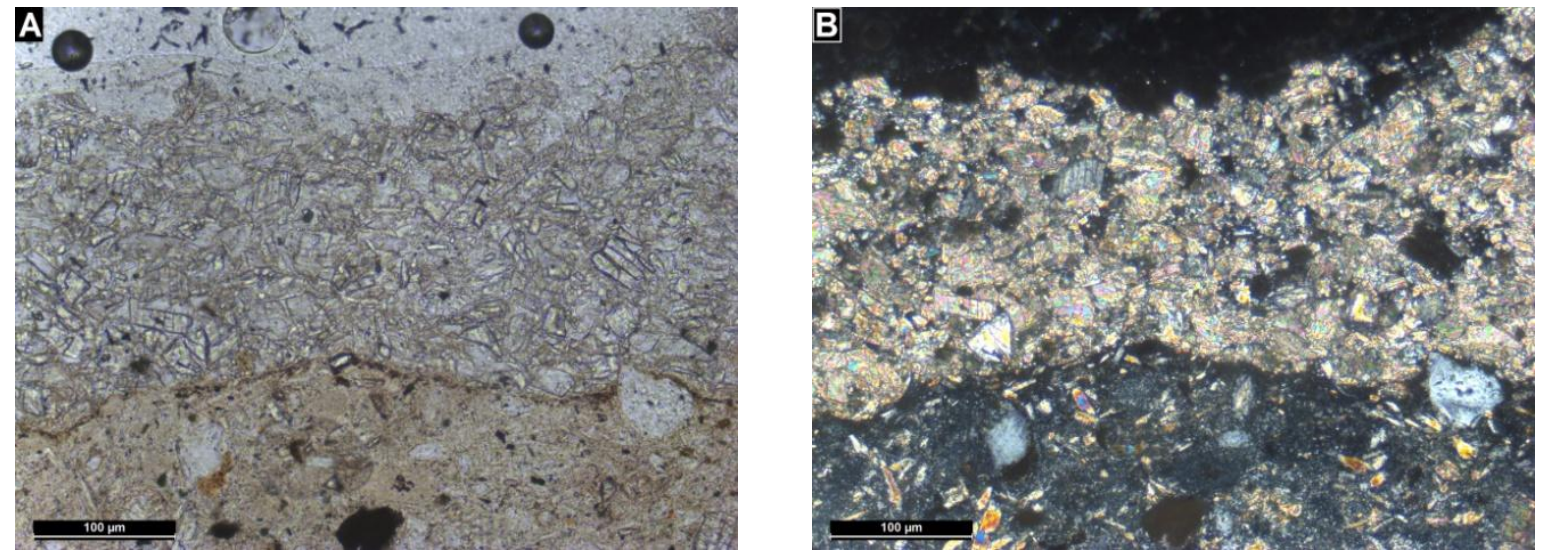

Figura 73: Fotomicrografia da amostra 04, com enfoque na camada 'Il'. A: Polarizadores paralelos; B: Polarizadores cruzados.
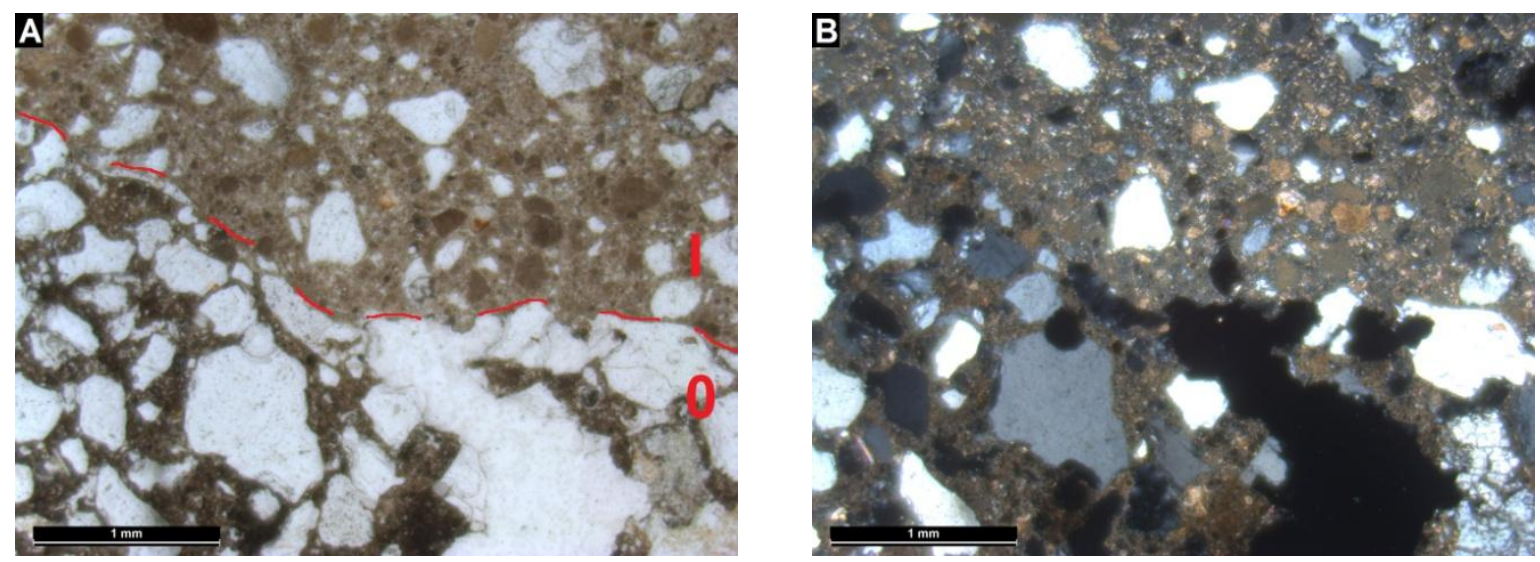

Figura 74: Fotomicrografia da amostra 04. Tracejado indica o contato entre as camadas '0' e 'l'. A: Polarizadores paralelos; B: Polarizadores cruzados. 
Assim como ocorre na amostra 02, nas camadas '0' e 'l' da amostra 04 há grãos que correspondem a porções de clínquer de cimento Portland que não foram completamente hidratados (Figuras 75 e 76). Isso confirma a presença deste material em ambas as camadas.

Na camada ' 0 ' - de cor cinza escuro e dureza alta - esses grãos possuem em média entre 100 e $200 \mu \mathrm{m}$ de diâmetro, e representam aproximadamente $10 \%$ do material que compõe a matriz. Há também nesta matriz entre 3 e $5 \%$ de grumos de material opaco.

A camada 'l' - de cor branca e dureza baixa - apresenta traços desses grãos, que possuem diâmetro entre 50 e $100 \mu \mathrm{m}$ aproximadamente. Nas Figuras $76_{\mathrm{A}}$ e $76_{\mathrm{B}}$ foram desenhadas em vermelho linhas guia, pois no momento em que a imagem da Figura $76_{B}$ foi registrada houve um leve giro da platina do microscópio, o que pode confundir a visualização da imagem com polarizadores cruzados.
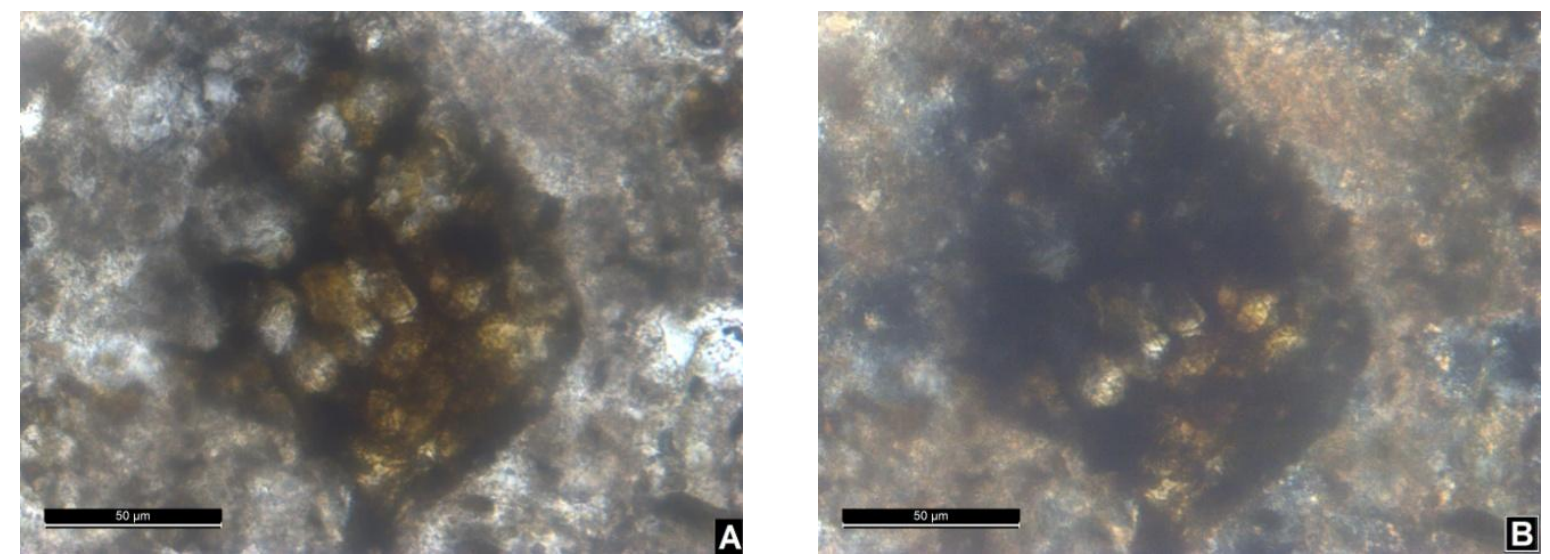

Figura 75: Fotomicrografia da amostra 04. Grãos de clínquer de cimento Portland presentes na camada '0'. A: Polarizadores paralelos. B: Polarizadores cruzados.
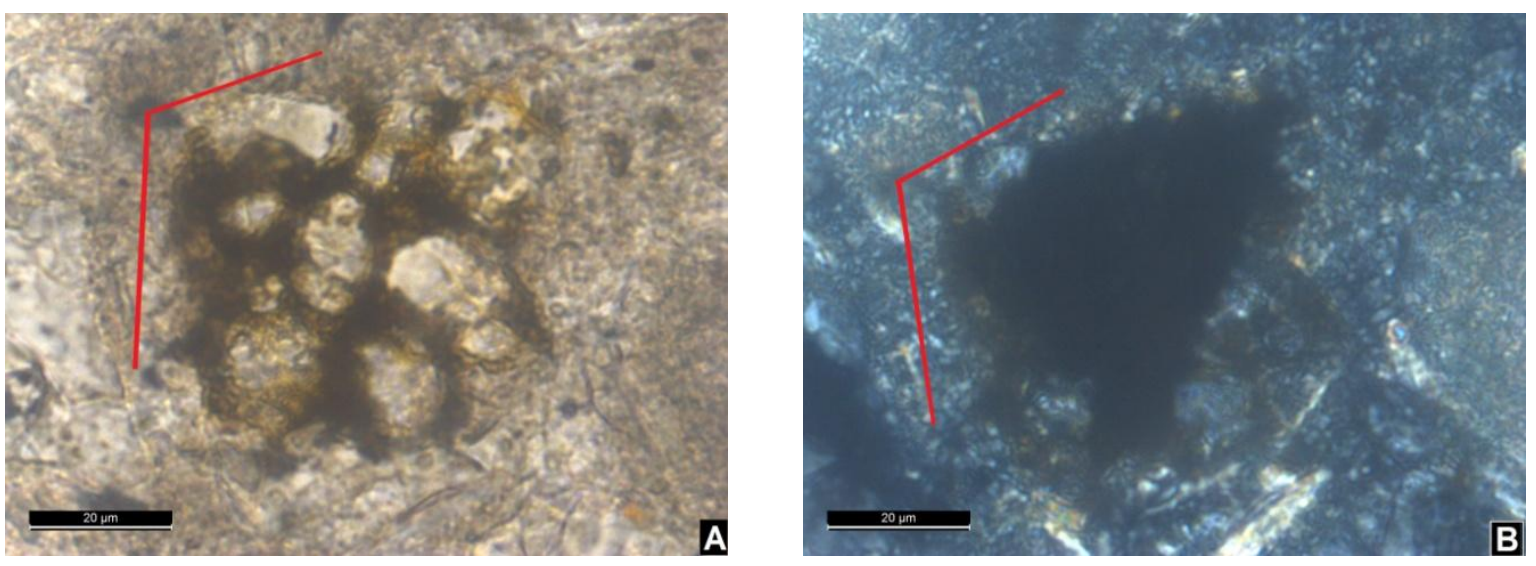

Figura 76: Fotomicrografia da amostra 04. Grãos de clínquer de cimento Portland presentes na camada 'l'. A: Polarizadores paralelos. B: Polarizadores cruzados. 


\subsubsection{MEV/EDS - CORTE ESTRATIGRÁFICO}

A Figura $77_{A}$ mostra o fragmento da amostra 04 embutido em resina, e a Figura $77_{B}$ corresponde a uma aproximação na região deste fragmento que foi analisada no MEV/EDS.
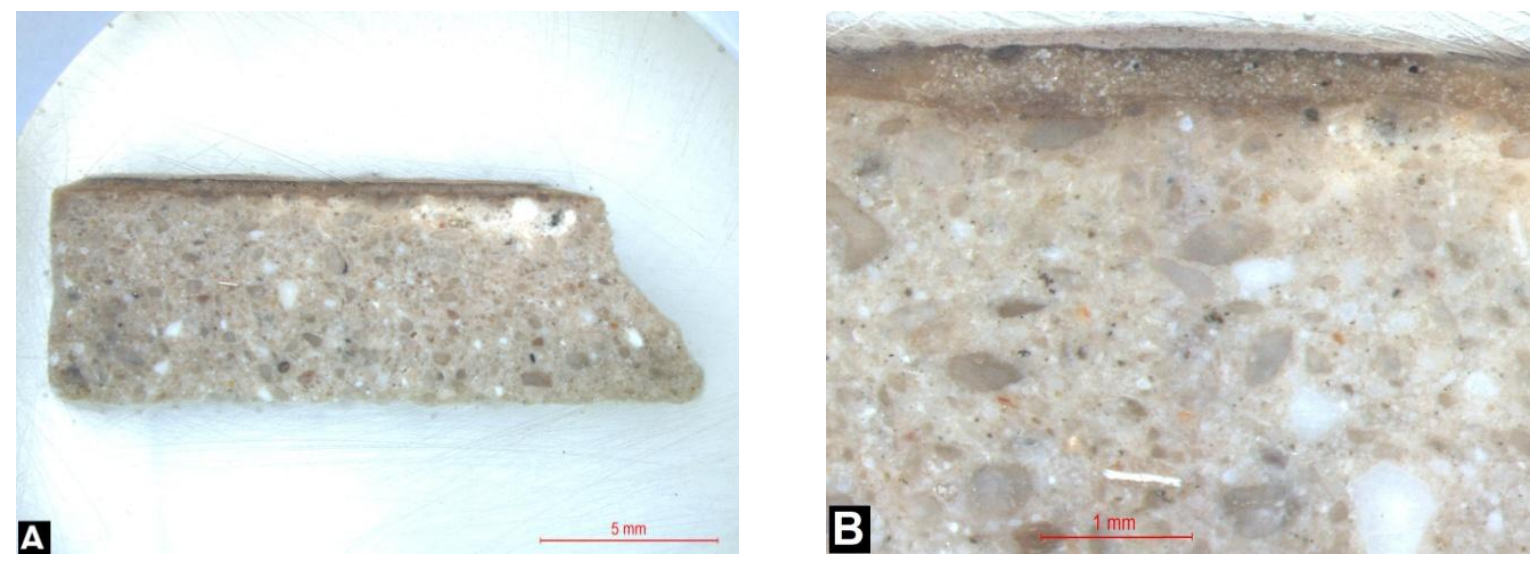

Figura 77 : Fragmento da amostra 04 embutido em resina para ser analisado em MEV/EDS. 77B: Região do fragmento da amostra 04 analisada no MEV/EDS.

A exposição dos dados coletados para a amostra 04 segue o modelo do exposto anteriormente para a amostra 02 , por serem altamente similares. A Figura $78_{\mathrm{A}}$ mostra a área da amostra 04 usada para os mapeamentos composicionais dos seguintes elementos: $\mathrm{Ca}, \mathrm{Mg}, \mathrm{Al}, \mathrm{K}, \mathrm{Si}, \mathrm{Ti}, \mathrm{Fe}, \mathrm{Na}, \mathrm{P}$ e $\mathrm{S}$, sendo que os quatro últimos não apresentaram distribuição nos mapas. A Figura $78_{\mathrm{B}}$ mostra as quatro áreas a partir das quais foram lidos espectros composicionais pelo EDS.
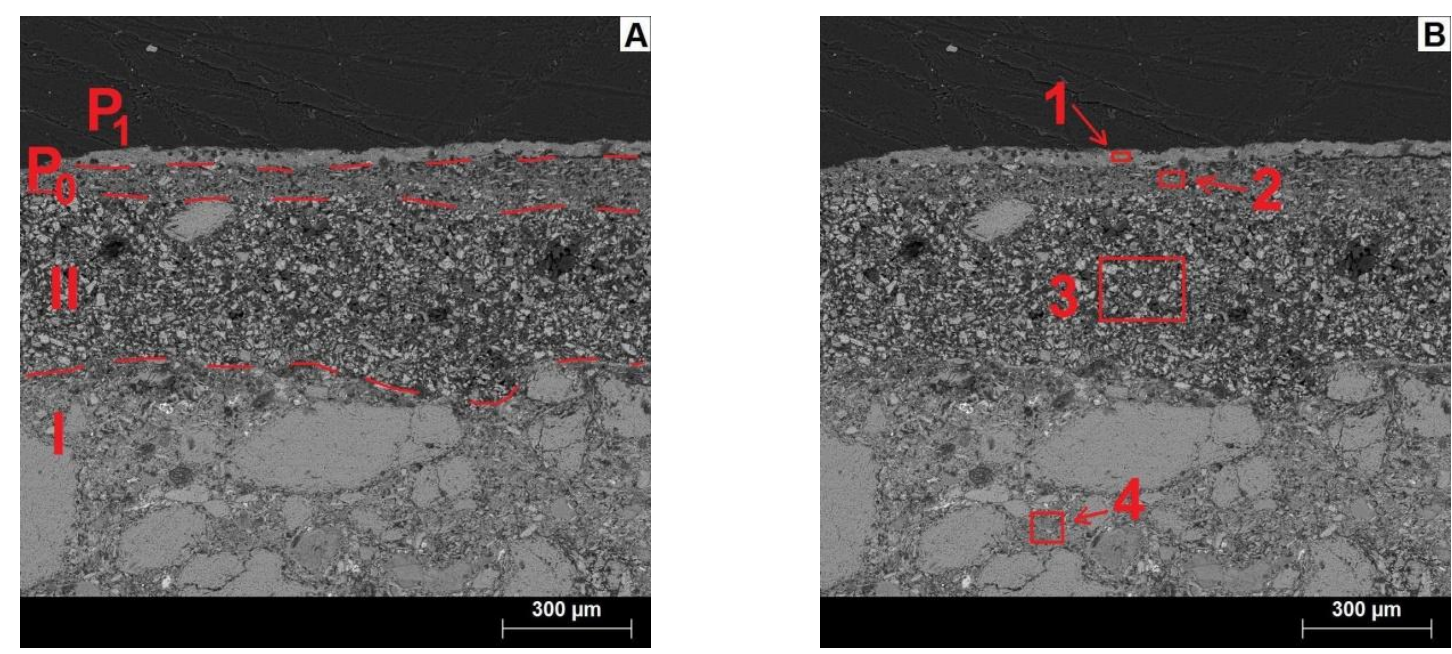

Figura 78: Área da amostra 04 com delimitação das camadas. Figura $78_{\mathrm{B}}$ : Os retângulos indicam as áreas da amostra 04 de onde foram lidos espectros composicionais por EDS. Imagens de elétrons retroespalhados. 
Observando em conjunto os mapeamentos composicionais das Figuras 79 a 81 e os espectros composicionais das Figuras 82 a 85 , foram resumidos os seguintes dados:

- as camadas $\mathrm{P}_{0}$ e $\mathrm{P}_{1}$ contêm os elementos Ti, $\mathrm{Si}, \mathrm{Al}, \mathrm{K}, \mathrm{Ca}, \mathrm{Mg}$ e Cl. Pelos mapas composicionais, pode-se observar que os elementos $\mathrm{Ti}, \mathrm{Si}, \mathrm{Al}$ e $\mathrm{K}$ fazem parte do material fino que envolve grãos compostos de $\mathrm{Ca}, \mathrm{Si}$, e em menor quantidade $\mathrm{Mg}(\mathrm{Cl}$ não faz parte dos elementos que figuram nos mapeamentos composicionais). Ambas as camadas correspondem química e texturalmente à camada $\mathrm{P}_{0}$ da amostra 02.

- a camada 'Il' é composta de $\mathrm{Ca}, \mathrm{Mg}$, Si e Cl, sendo rico em Ca o material fino que envolve os grãos, e esses possuem $\mathrm{Ca}, \mathrm{Mg}$ e $\mathrm{Si}$ em suas composições. (Não foi feito mapa composicional para o elemento $\mathrm{Cl}$ ). Este material é o mesmo encontrado na camada correspondente na amostra 02.

- a camada 'l' é uma camada de argamassa contendo como aglomerante mistura de cimento Portland com cal e/ou argilas, e agregados de mineralogia diversa (quartzo, micas, torrões de lama carbonática, feldspatos), conforme dados das descrições macroscópica e petrográfica. Os mapas e espectros composicionais revelam que os elementos componentes desta camada são: $\mathrm{Ca}, \mathrm{Mg}, \mathrm{Si}, \mathrm{Al}, \mathrm{K}, \mathrm{Cl}$ e S. Com exceção do $\mathrm{Cl}$, são todos elementos esperados para confirmarem a composição desta camada. O elemento $\mathrm{Cl}$ aparece nas diversas camadas; há possibilidade deste elemento ser parte componente da resina usada para embutir as amostras.

A camada '0' não figura nesta área analisada da amostra 04 . 

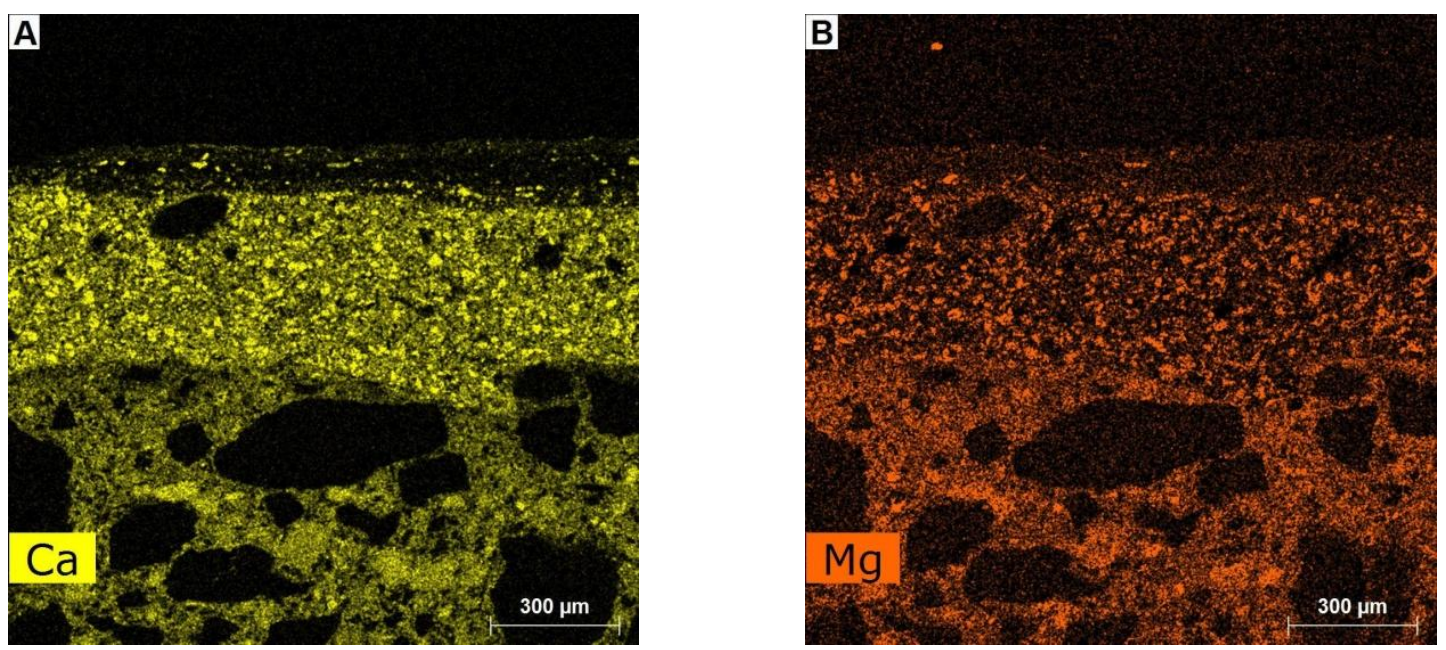

Figura 79: Mapeamentos composicionais por EDS na área da amostra 04 analisada em MEV. A: Mapeamento do elemento Ca; B: Mapeamento do elemento Mg.
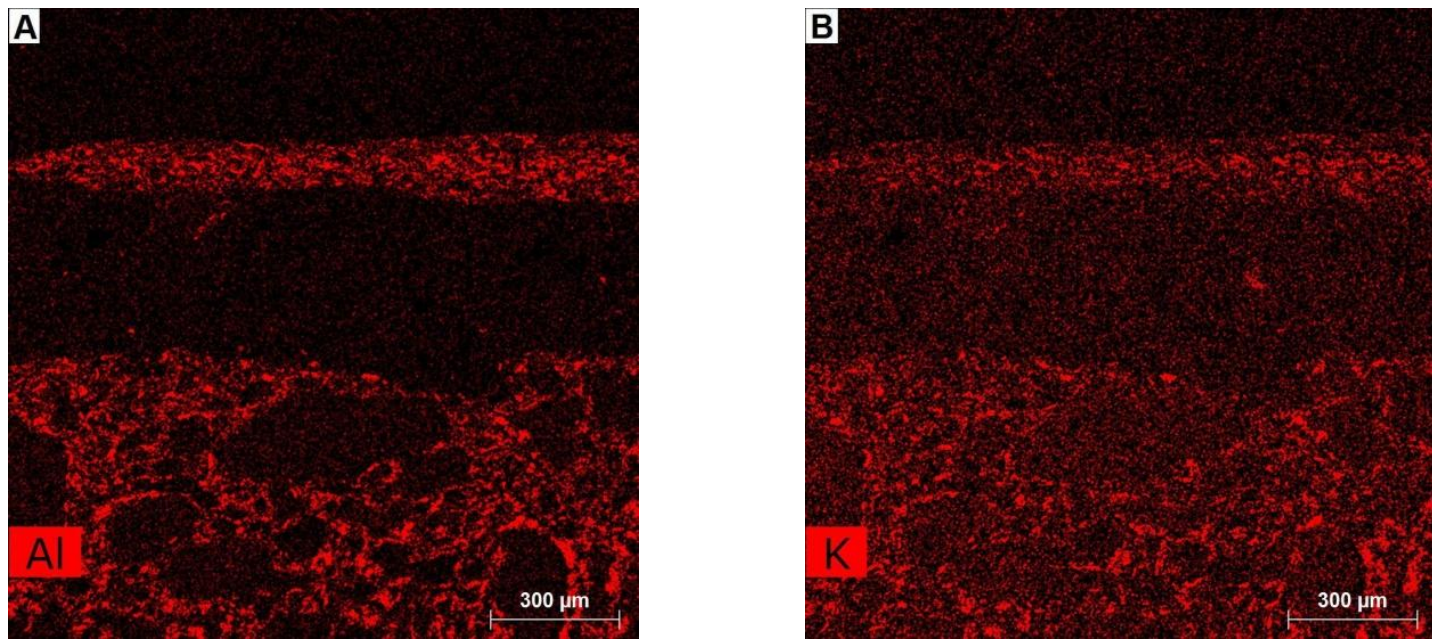

Figura 80: Mapeamentos composicionais por EDS na área da amostra 04 analisada em MEV. A: Mapeamento do elemento Al; B: Mapeamento do elemento K.
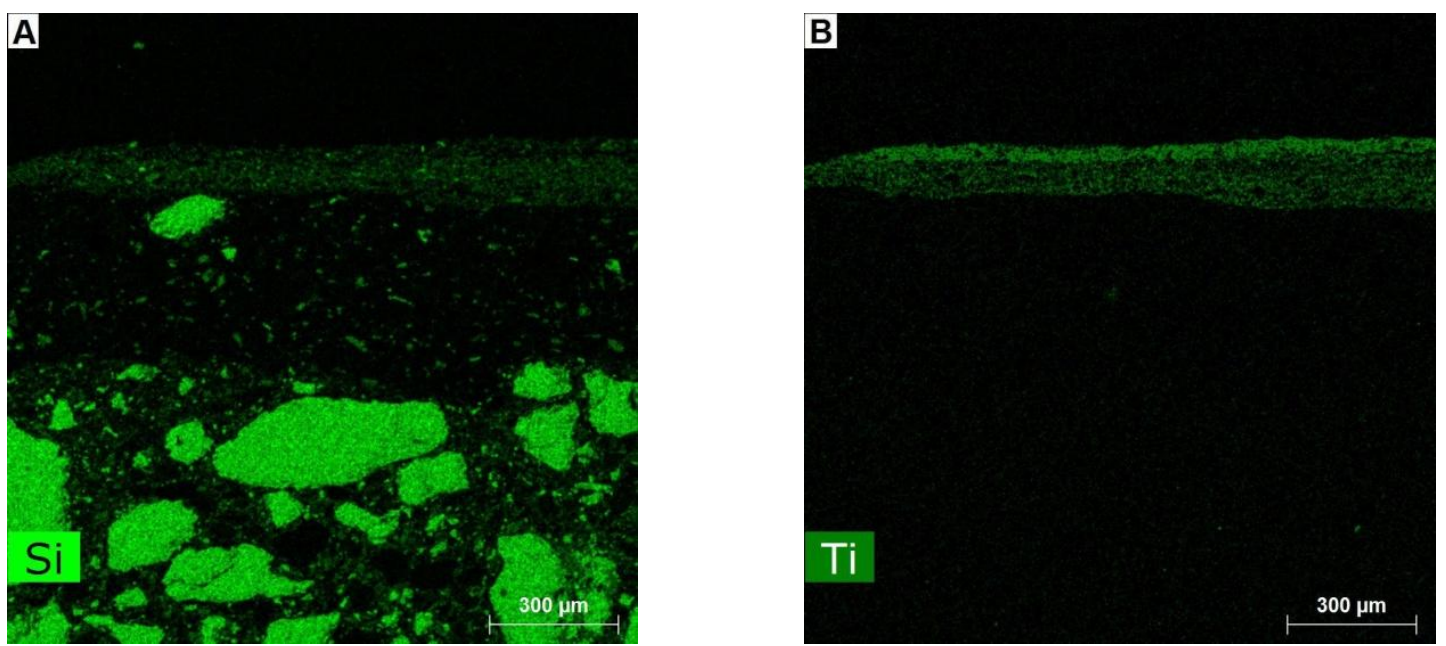

Figura 81: Mapeamentos composicionais por EDS na área da amostra 04 analisada em MEV. A: Mapeamento do elemento Si. B: Mapeamento do elemento Ti. 


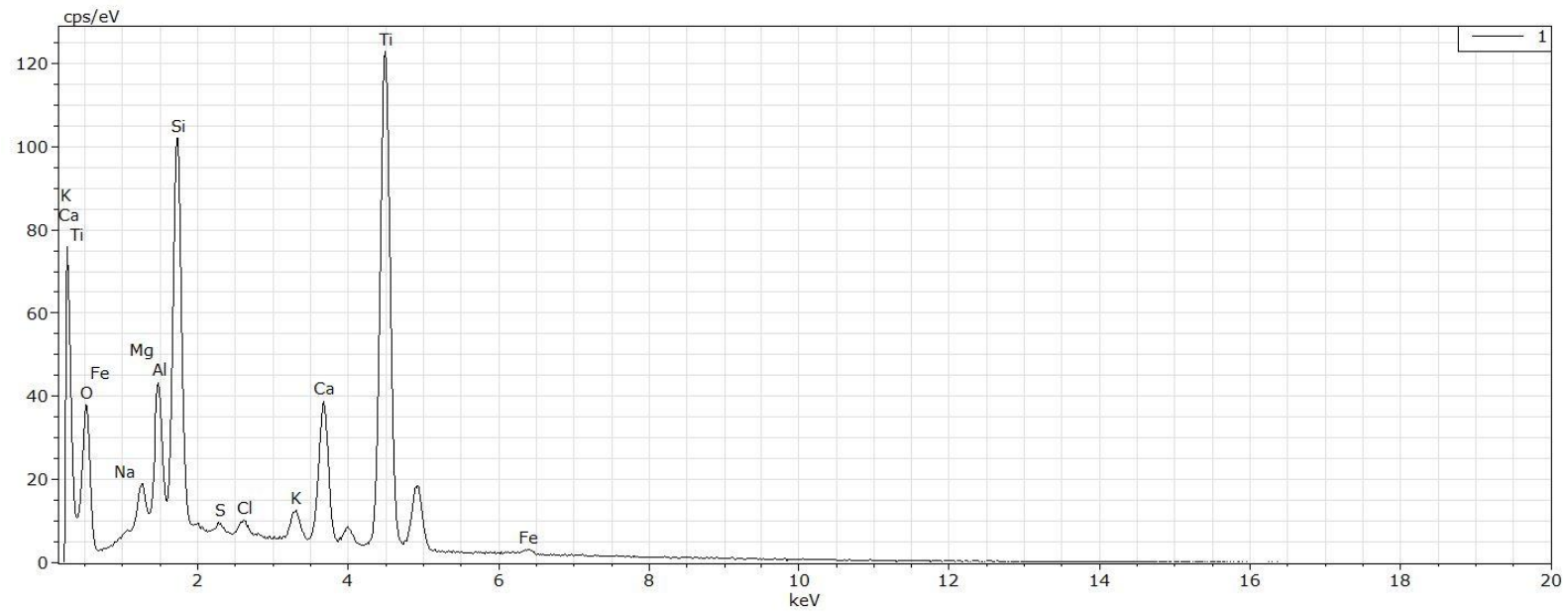

Figura 82: Espectro composicional por EDS da área '1', dentro da camada $\mathrm{P}_{1}$, marcada na Figura $78_{\mathrm{B}}$.

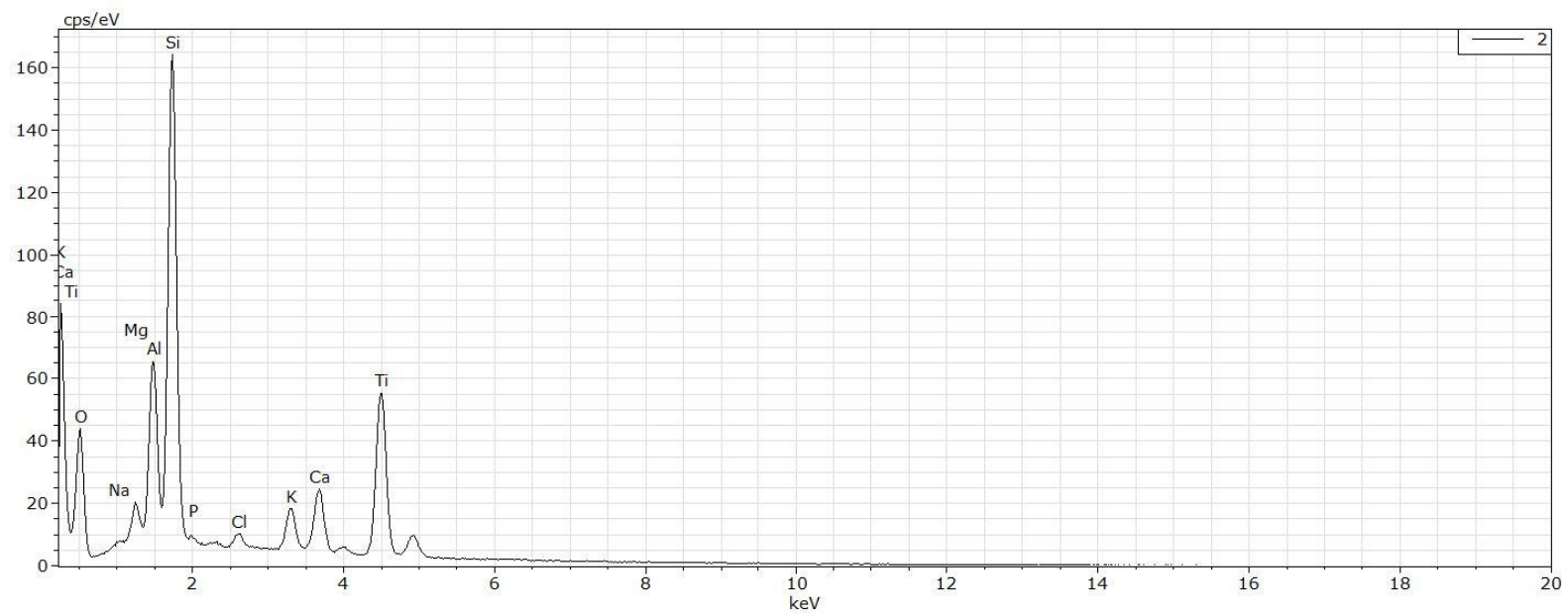

Figura 83: Espectro composicional por EDS da área '2', dentro da camada $\mathrm{P}_{0}$, marcada na Figura $78_{\mathrm{B}}$.

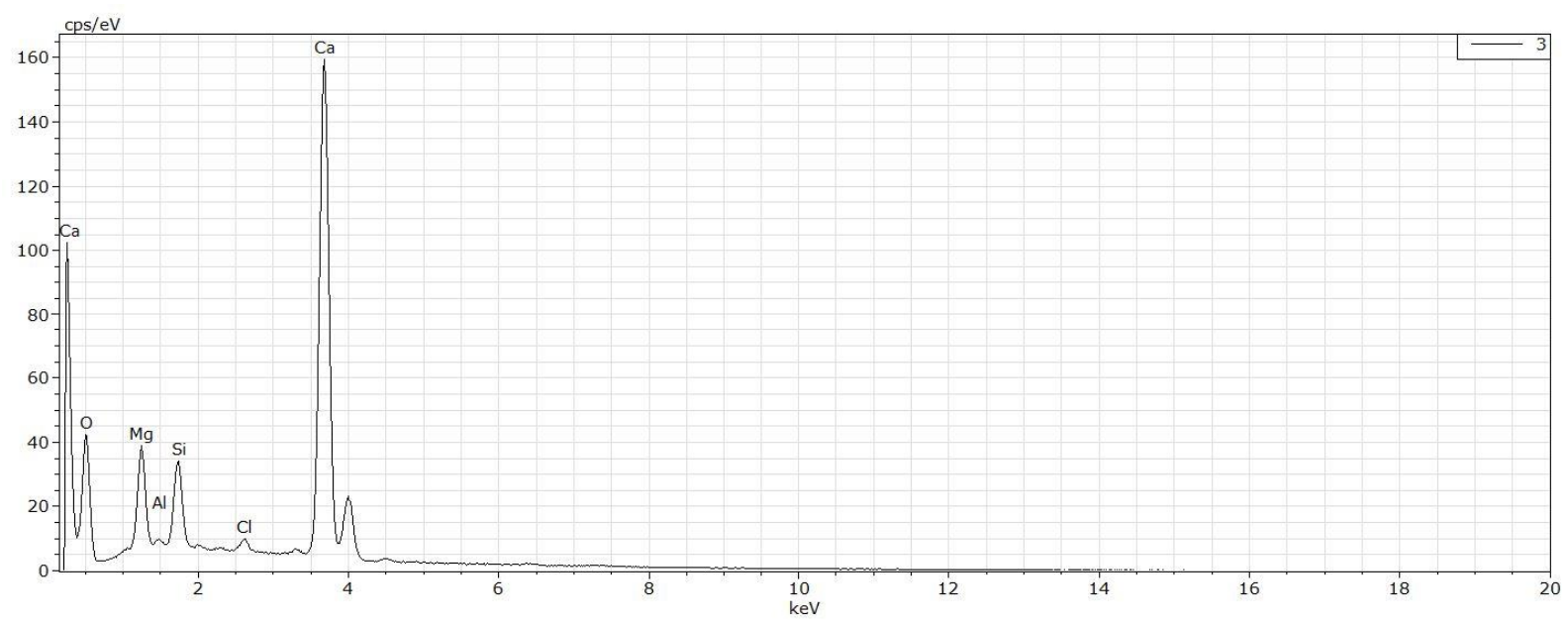

Figura 84: Espectro composicional por EDS da área '3', dentro da camada, 'II', marcada na Figura $78_{\mathrm{B}}$. 


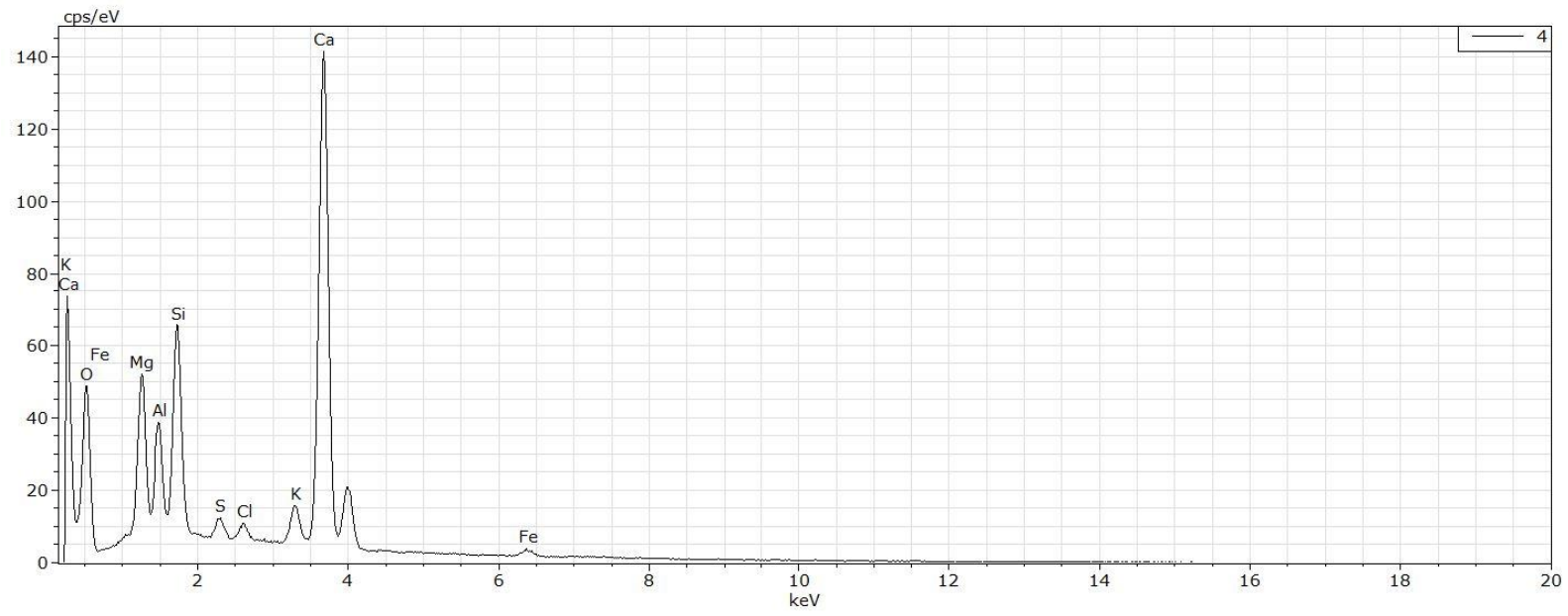

Figura 85: Espectro composicional por EDS da área '4', dentro da camada 'l', marcada na Figura $78_{\mathrm{B}}$. 


\subsubsection{FLUORESCÊNCIA DE RAIOS X}

Os elementos presentes nos mapeamentos feitos no EDS para a superfície da amostra 04 correspondem aos elementos que se destacaram nesta análise de FRX por varredura superficial (Tabela 4), com exceção do Mg, presente nas camadas 'Il' e ' $l$ ', que aparece nesta análise provavelmente em razão da perda parcial de material que a amostra apresenta.

Tabela 4: Dados semiquantitativos (\%) de espectrometria de fluorescência de raios $X$ de varredura superficial, de todas as amostras para comparação.

\begin{tabular}{|c|c|c|c|c|c|}
\hline AMOSTRA & 01 & 02 & 03 & 04 & 05 \\
\hline Sum sem norm & 75,7 & 88,8 & 67,3 & 82,7 & 66,4 \\
\hline $\mathrm{Na}_{2} \mathrm{O}$ & 0,14 & 0,096 & 0,111 & 0,073 & 0,118 \\
\hline $\mathrm{MgO}$ & 5,177 & 4,533 & 47,342 & 4,902 & 9,187 \\
\hline $\mathrm{Al}_{2} \mathrm{O}_{3}$ & 3,662 & 4,341 & 3,478 & 6,188 & 6,812 \\
\hline $\mathrm{SiO}_{2}$ & 7,908 & 7,484 & 4,827 & 11,623 & 17,706 \\
\hline $\mathrm{P}_{2} \mathrm{O}_{5}$ & 0,094 & 0,291 & 0,091 & 0,184 & 0,263 \\
\hline $\mathrm{SO}_{3}$ & 5,834 & 1,179 & 0,517 & 0,828 & 2,105 \\
\hline $\mathrm{Cl}$ & 0,39 & 0,265 & 0,228 & 0,301 & 0,299 \\
\hline $\mathrm{K}_{2} \mathrm{O}$ & 0,31 & 0,419 & 0,208 & 1,16 & 0,541 \\
\hline $\mathrm{CaO}$ & 70,313 & 46,736 & 40,688 & 43,212 & 59,214 \\
\hline $\mathrm{TiO}_{2}$ & 2,614 & 33,64 & 0,777 & 30,615 & \\
\hline $\mathrm{Cr}$ & 0,013 & 0,018 & 0,012 & 0,026 & 0,019 \\
\hline $\mathrm{MnO}$ & 0,078 & 0,035 & 0,044 & 0,007 & \\
\hline $\mathrm{Fe}_{2} \mathrm{O}_{3}$ & 3,228 & 0,638 & 1,335 & 0,482 & 2,43 \\
\hline $\mathrm{Ni}$ & 0,004 & 0,005 & 0,007 & 0,005 & 0,006 \\
\hline $\mathrm{Cu}$ & 0,018 & 0,018 & 0,037 & 0,01 & 0,022 \\
\hline $\mathrm{Zn}$ & 0,037 & 0,076 & 0,091 & 0,023 & 0,138 \\
\hline $\mathrm{Rb}$ & 0,005 & 0,007 & 0,009 & 0,007 & 0,006 \\
\hline $\mathrm{Sr}$ & 0,105 & 0,089 & 0,021 & 0,043 & 0,059 \\
\hline $\mathrm{Y}$ & 0,003 & 0,002 & 0,004 & 0,002 & 0,002 \\
\hline $\mathrm{Zr}$ & 0,033 & 0,031 & 0,038 & 0,019 & 0,027 \\
\hline $\mathrm{Ba}$ & 0,031 & 0,07 & 0,122 & 0,053 & 0,104 \\
\hline $\mathrm{Pb}$ & 0,004 & 0,019 & 0,011 & 0,011 & 0,015 \\
\hline $\mathrm{Br}$ & & & & & 0,002 \\
\hline $\mathrm{Ce}$ & & & & & 0,102 \\
\hline Co & & & & & 0,138 \\
\hline $\mathrm{F}$ & & & & 0,219 & 0,289 \\
\hline $\mathrm{Ga}$ & & 0,002 & & & \\
\hline $\mathrm{Mn}$ & & & & & 0,097 \\
\hline $\mathrm{Nb}$ & & 0,007 & & 0,008 & \\
\hline $\mathrm{Ti}$ & & & & & 0,298 \\
\hline
\end{tabular}




\subsubsection{LANTERNA UV}

Sob radiação UV (Figuras $86_{A}$, e $86_{B}$ para comparação), as camadas comportam-se de maneiras diferentes. A camada superficial $\left(P_{1}\right)$ aparenta estar suja, pois há porções que permanecem escuras, e outras que emitem luz roxa. A camada $\mathrm{P}_{0}$ emite luz roxa de maneira bastante homogênea. Há dois locais na parte superior da imagem com perda mais aguda de material. Na parte superior esquerda a camada 'Il' está exposta, emitindo luz rosa claro. O canto superior direito, onde está exposta a camada 'l', emite luz azul claro.
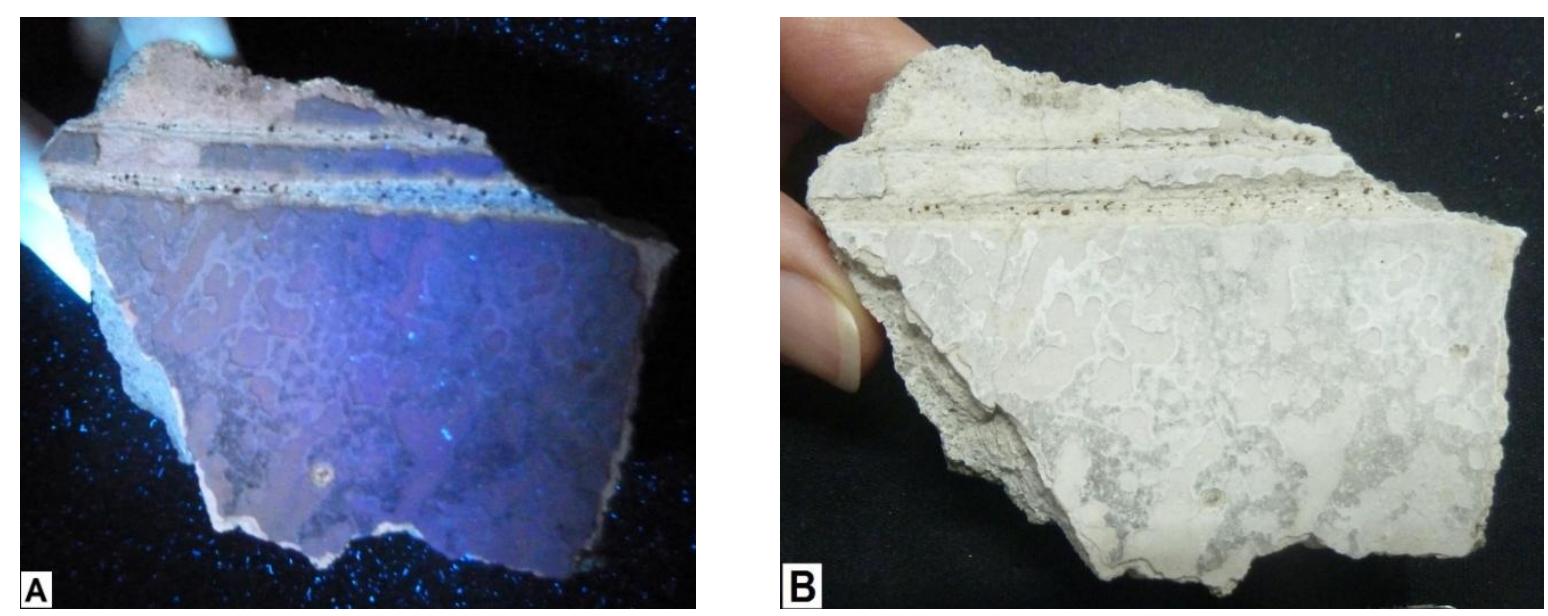

Figura 86 $\mathrm{A}$ : Amostra 04 iluminada por lanterna UV; 86⿸尸 ambiente para comparação. 


\subsubsection{CONCLUSÕES SOBRE A AMOSTRA 04}

A amostra 04 é similar à amostra 02, no que diz respeito aos materiais e à estratigrafia. Desse modo, as conclusões são as mesmas: trata-se de trecho da parede que passou por reforma posterior à confecção do mural.

Por cima de um conduíte plástico foi aplicada camada de argamassa de cimento Portland, contendo areia fina a média composta de grãos de quartzo e feldspato. Foi sobreposta a esta, camada de argamassa contendo mistura de cimento Portland com cal e/ou argilas, e agregado majoritariamente fino de mineralogia diversa (quartzo, micas, torrões de lama carbonática e feldspatos). As três camadas superficiais são interpretadas como massa industrializada para acabamento de paredes, sobreposta por duas demãos de tinta industrializada para paredes.

A diferença notável entre esta e a amostra 02 é a composição da camada externa. No caso da amostra 02, as duas demãos de tinta dizem respeito a duas tintas de composições diferentes. Já nesta amostra 04, para as duas demãos foi usado o mesmo produto. 


\subsection{AMOSTRA 05}

\subsubsection{DESCRIÇÃO MACROSCÓPICA}

A amostra 05 possui superfície rugosa e sua cor predominante é o branco acinzentado. Na porção inferior direita há marcas do incêndio (Figura 87). Segundo a tabela Rock-Color Chart (ROCK-COLOR CHART COMMITTEE, 1963), a cor que mais se aproxima da cor da superfície desta amostra é a "Very light gray N 8".

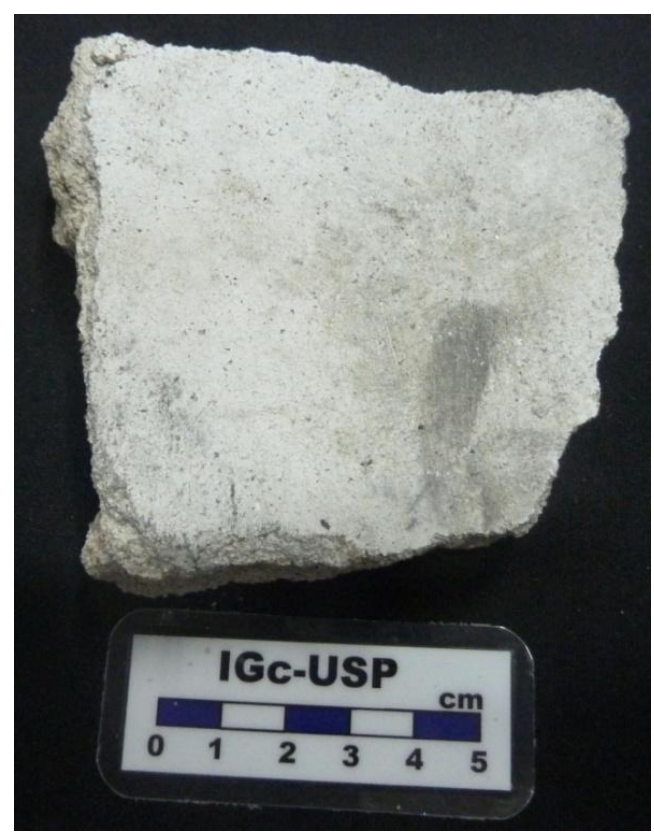

Figura 87: Amostra 05.

No corte estratigráfico da amostra 05 (Figura 88) não são visíveis contatos entre diferentes materiais, o que leva a crer, nesta escala, ser a amostra composta por uma única camada. O aglomerante possui cor branca, contendo agregados angulosos, de esfericidade baixa, com granulometria de areia fina a média.

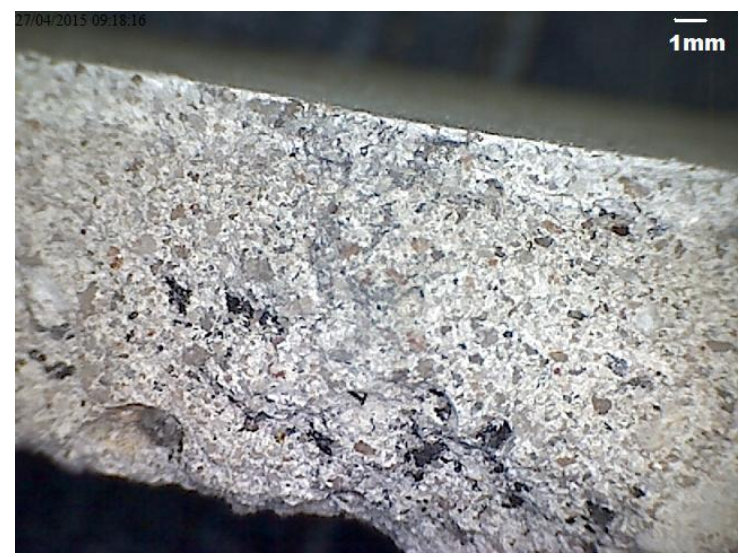

Figura 88: Corte estratigráfico da amostra 05. 


\subsubsection{DESCRIÇÃO PETROGRÁFICA}

O material que compõe a amostra possui como aglomerante material argiloso com aspecto de lama carbonática, com agregados angulosos de esfericidade baixa, granulometria predominante entre $100 \mu \mathrm{m}$ e $1 \mathrm{~mm}$, compostos principalmente por grãos de quartzo e feldspatos, e em menor quantidade micas e carbonatos (Figuras $89_{\mathrm{A}}$ e $89_{\mathrm{B}}$ ). Imersas nos $20 \mu \mathrm{m}$ superficiais da amostra, bem distribuídas, estão partículas azuis (Figuras $90_{\mathrm{A}}$ e $90_{\mathrm{B}}$ ), que por serem compostas de cobalto e alumínio (como apresentado adiante nos resultados do MEV/EDS), são aqui interpretadas como partículas de pigmento azul cobalto.
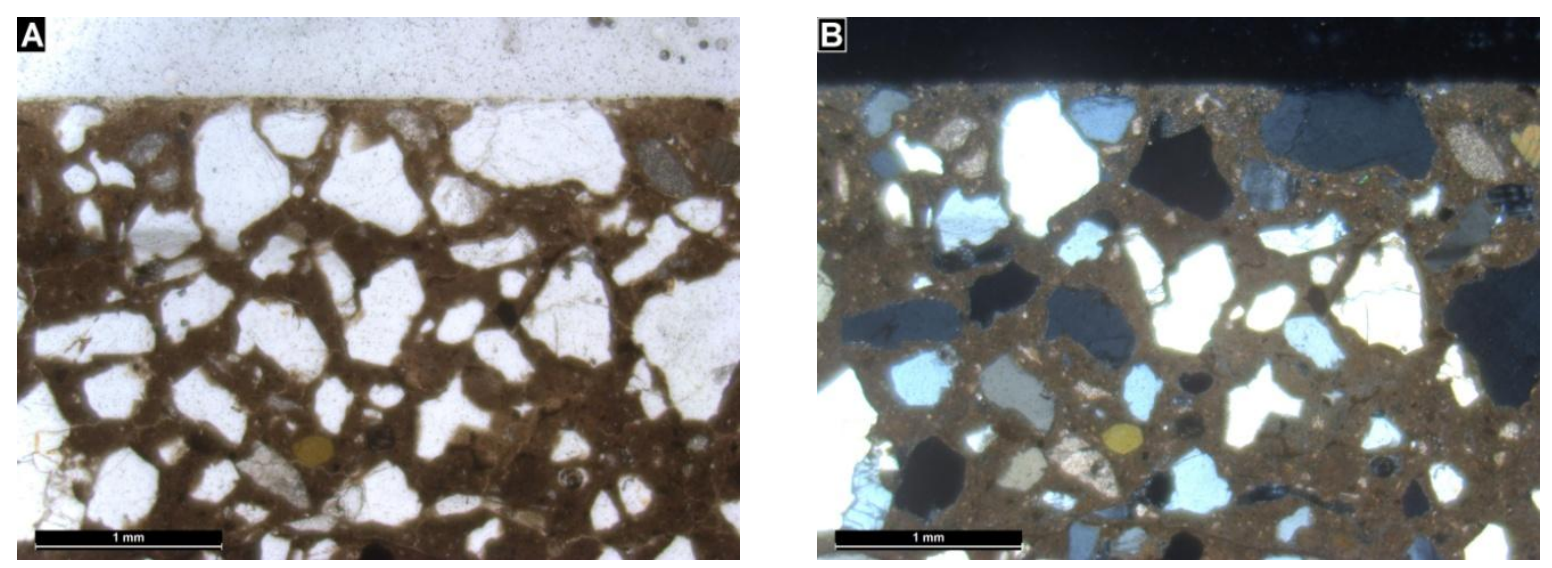

Figura 89: Fotomicrografia da amostra 05. A: Polarizadores paralelos. B: Polarizadores cruzados.
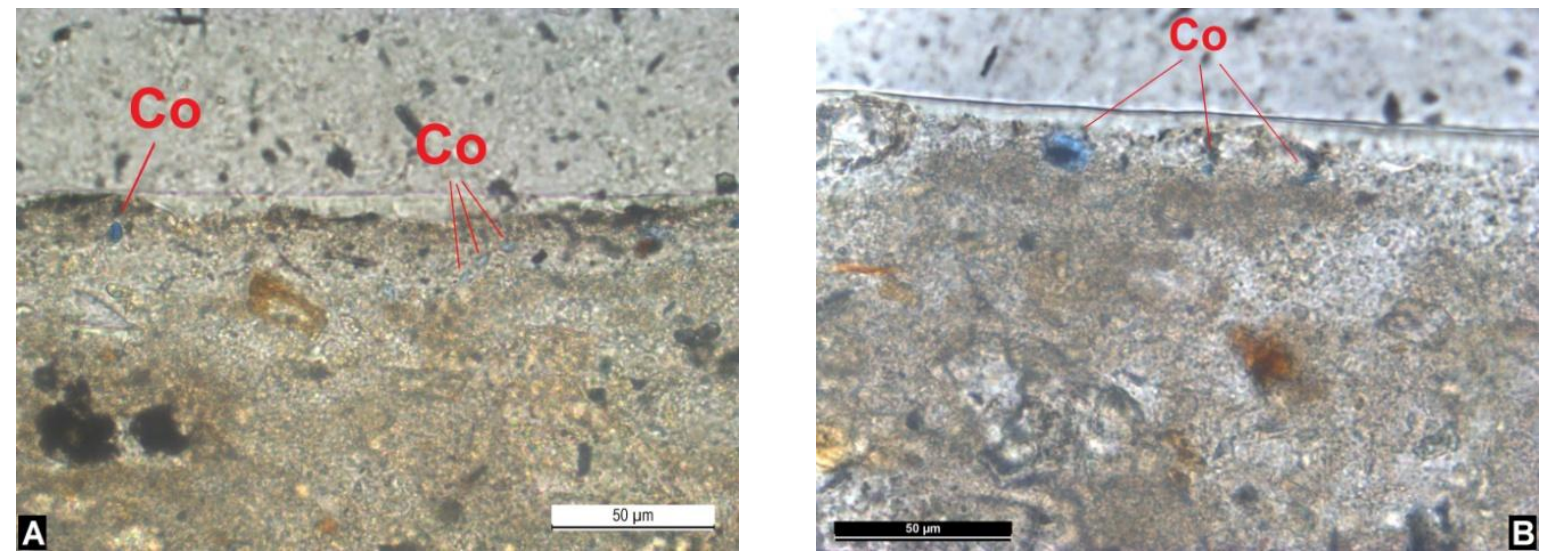

Figuras $90_{A}$ e $90_{B}$ : Ambas as imagens apresentam fotomicrografia da amostra 05 , com enfoque na superfície da camada pictórica contendo partículas de pigmento azul cobalto imersas nos primeiros micrômetros. Polarizadores paralelos. 


\subsection{3a MEV/EDS - CORTE ESTRATIGRÁFICO}

A partir do fragmento da amostra 05 embutido em resina (Figura 91A), foram escolhidas as áreas a serem analisadas no MEV. Na Figura 91 $\mathrm{B}$ é possível ver algumas partículas do pigmento azul cobalto.
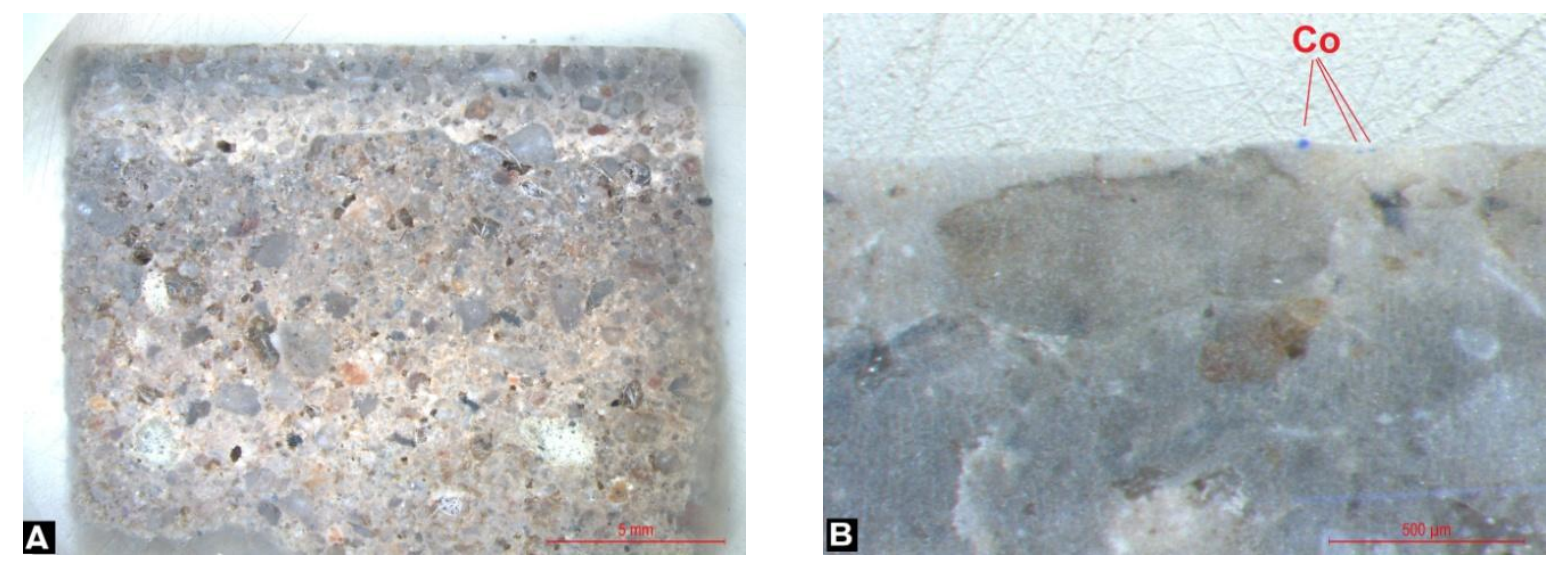

Figura 91 $\mathrm{A}$ : Fragmento da amostra 05 embutido em resina para ser analisado em

MEV/EDS. 91 : Parte da região do fragmento da amostra 05 analisada no $\mathrm{MEV/EDS}$. Setas indicam a presença das partículas do pigmento azul cobalto.

$\mathrm{Na}$ primeira área analisada (Figura 92A) é possível observar que foi usado aglomerante de cal enriquecida em cálcio, com baixa concentração de magnésio (Figuras $92_{B}$ e 93 ${ }_{A}$ ). Estas mesmas Figuras revelam também os grãos de composição carbonática usados como agregado. As Figuras $93_{B}, 94_{A}$ e $94_{B}$ mostram os grãos de quartzo e feldspatos presentes no agregado. A Figura 95 mostra a presença do elemento $S$ na argamassa, evidenciando, assim como na amostra 01, a adição de gesso na argamassa.

Foram também feitos mapeamentos composicionais para os seguintes elementos, sem apresentarem distribuição nos mapas: $\mathrm{Cu}, \mathrm{Fe}, \mathrm{Na}, \mathrm{P}$ e Ti. 

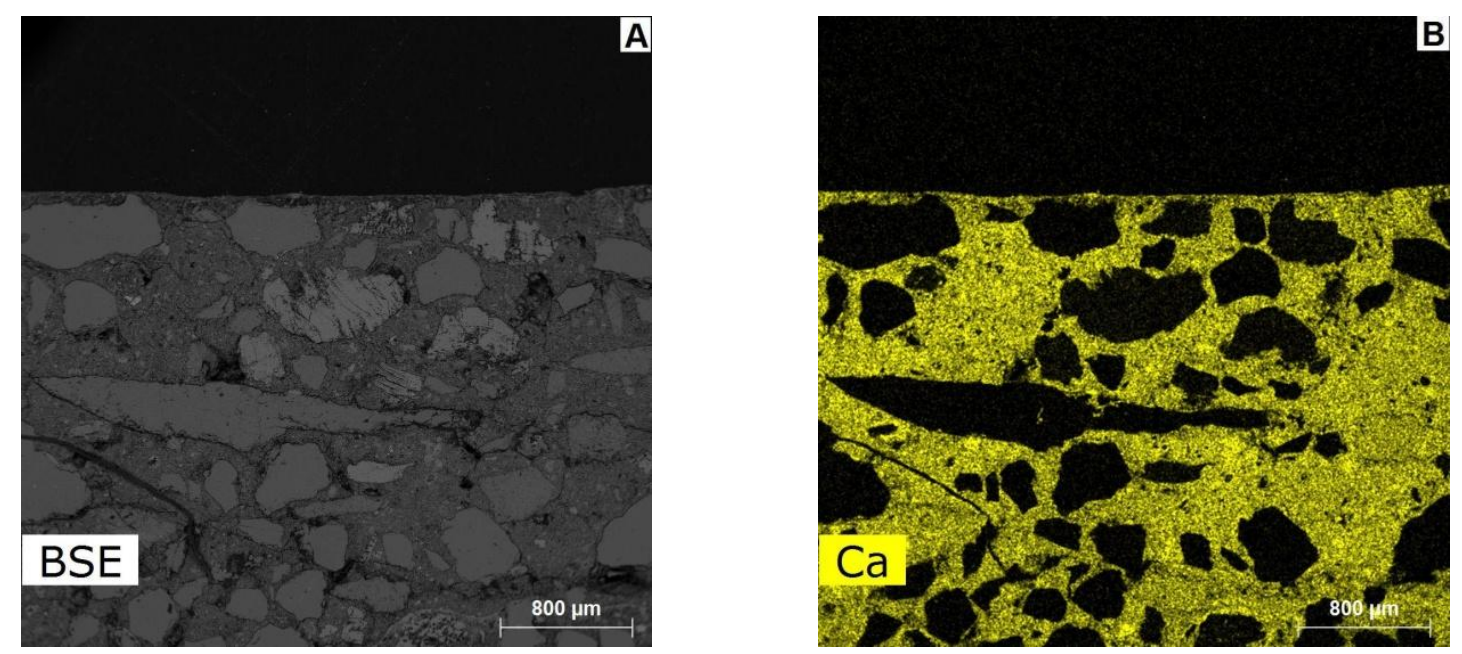

Figura 92A: Primeira área da amostra 05 analisada em MEV. Imagem de elétrons retroespalhados. 92 $\mathrm{B}$ : Mapeamento pelo EDS do elemento Ca na primeira área da amostra 05.
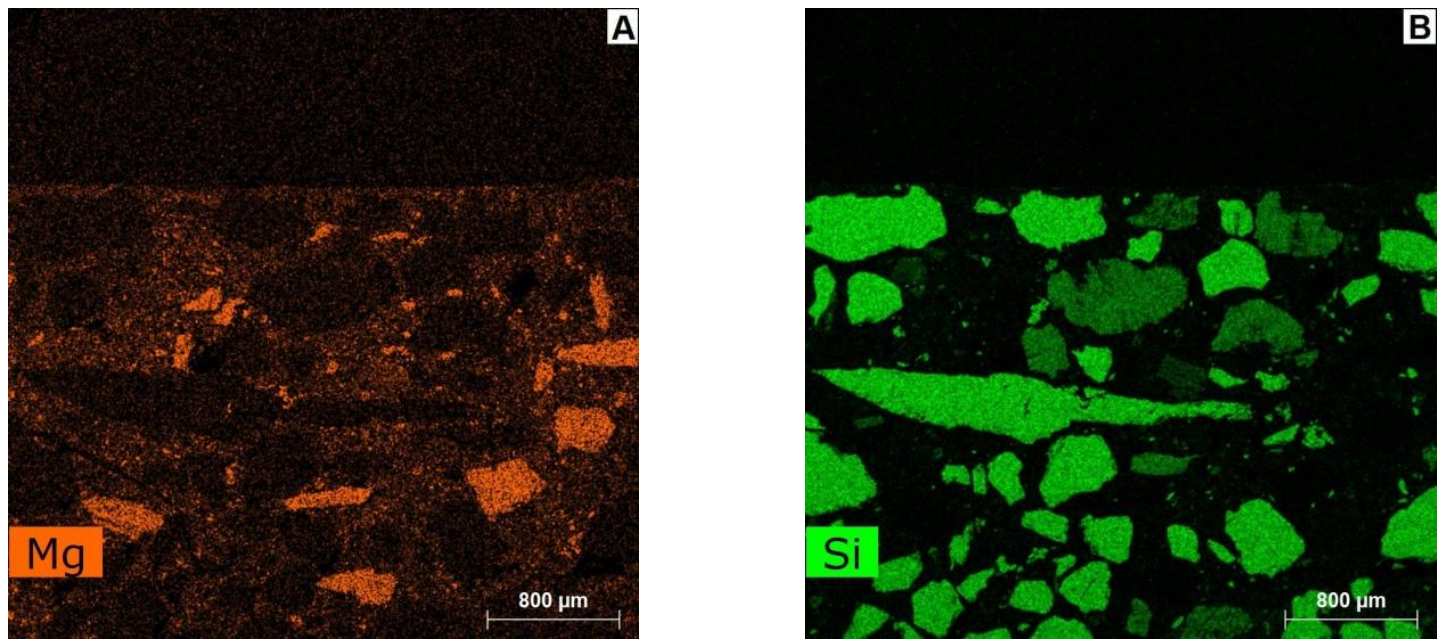

Figura 93: Mapeamentos composicionais por EDS na primeira área analisada da amostra 05. A: Mapeamento do elemento Mg; B: Mapeamento do elemento Si.
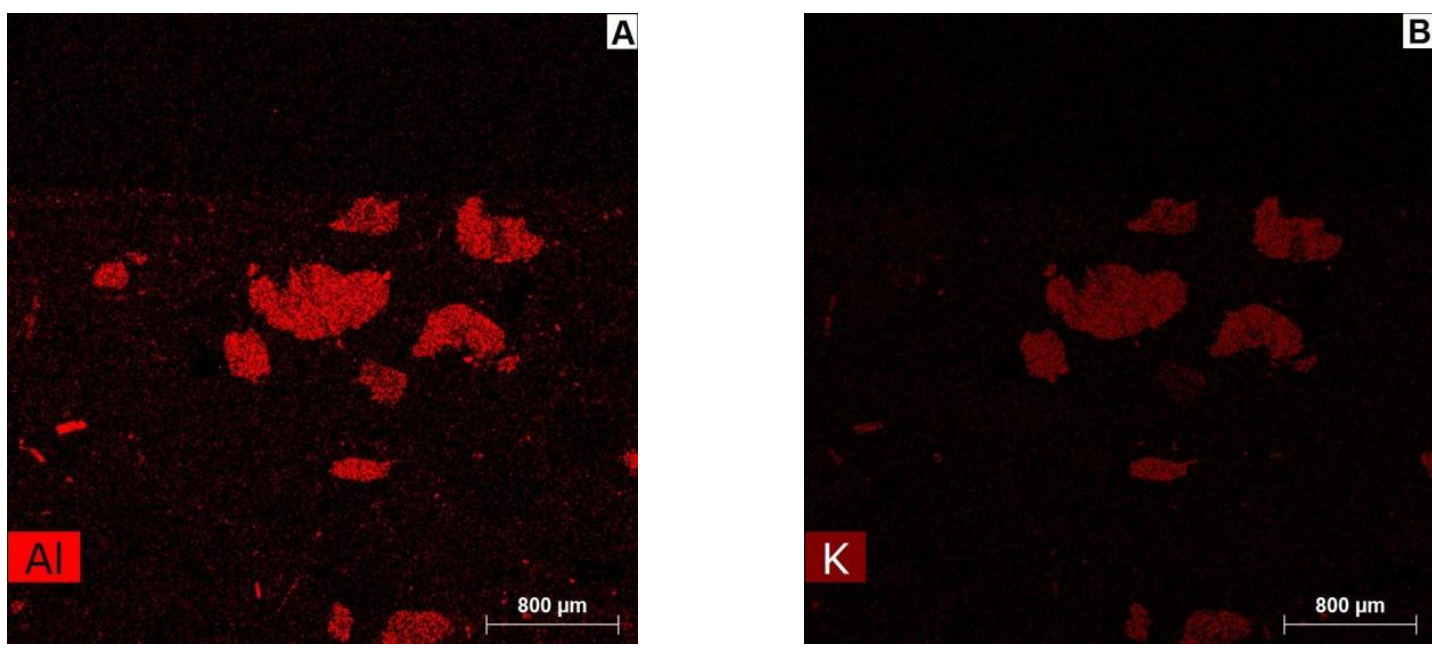

Figura 94: Mapeamentos composicionais por EDS na primeira área analisada da amostra 05. A: Mapeamento do elemento Al; B: Mapeamento do elemento K. 


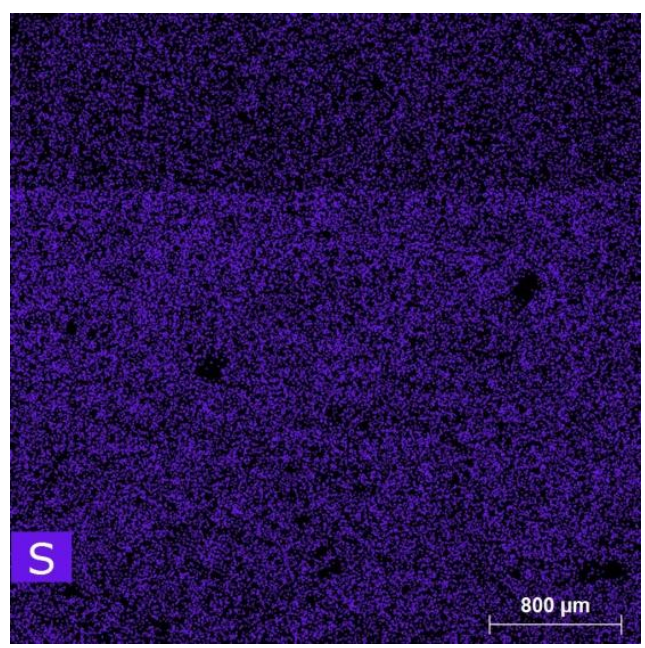

Figura 95: Mapeamento pelo EDS do elemento S na primeira área da amostra 05.

A segunda área analisada é uma aproximação com enfoque na superfície da amostra 05 (Figura 96A).

As Figuras $96_{\mathrm{B}}$ e $97_{\mathrm{A}}$ revelam a composição de três dos grãos de pigmento de cobalto já citados anteriormente, grãos esses que estão imersos nos primeiros 20 $\mu \mathrm{m}$, aproximadamente, da superfície da amostra 05.

As Figuras $97_{\mathrm{B}}$ e 98 mostram, respectivamente, concentração do elemento $\mathrm{S}$ e presença de detritos silicosos, ambos nos micrômetros superficiais da amostra. Estes resultados são interpretados como elementos presentes na água de cal usada pelo artista como veículo para aplicação do pigmento azul cobalto: os detritos silicosos são impurezas presentes na cal, e o S corresponde a adição de gesso com finalidades estéticas.

Na Figura 99 estão indicados com os números 1 e 2, respectivamente, uma área retangular e um ponto, em cima dos grãos apresentados nas Figuras 96 $\mathrm{A}_{\mathrm{A}}, 96_{\mathrm{B}}$ e $97_{\mathrm{A}}$. Destas regiões foram lidos espectros composicionais para confirmação da composição destes grãos, apresentados nas Figuras 100 e 101. 

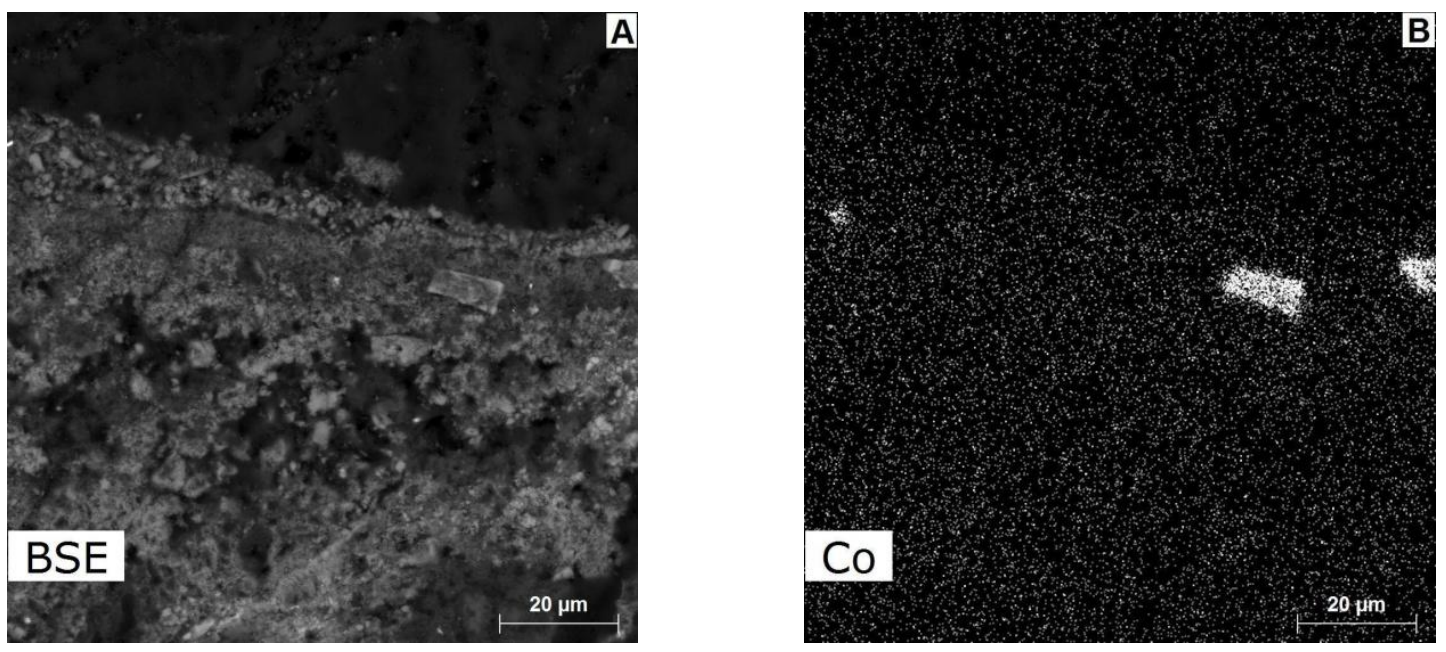

Figura 96A: Segunda área da amostra 05 analisada em MEV. Imagem de elétrons retroespalhados. 96 $\mathrm{B}$ : Mapeamento pelo EDS do elemento Co na segunda área analisada da amostra 05.
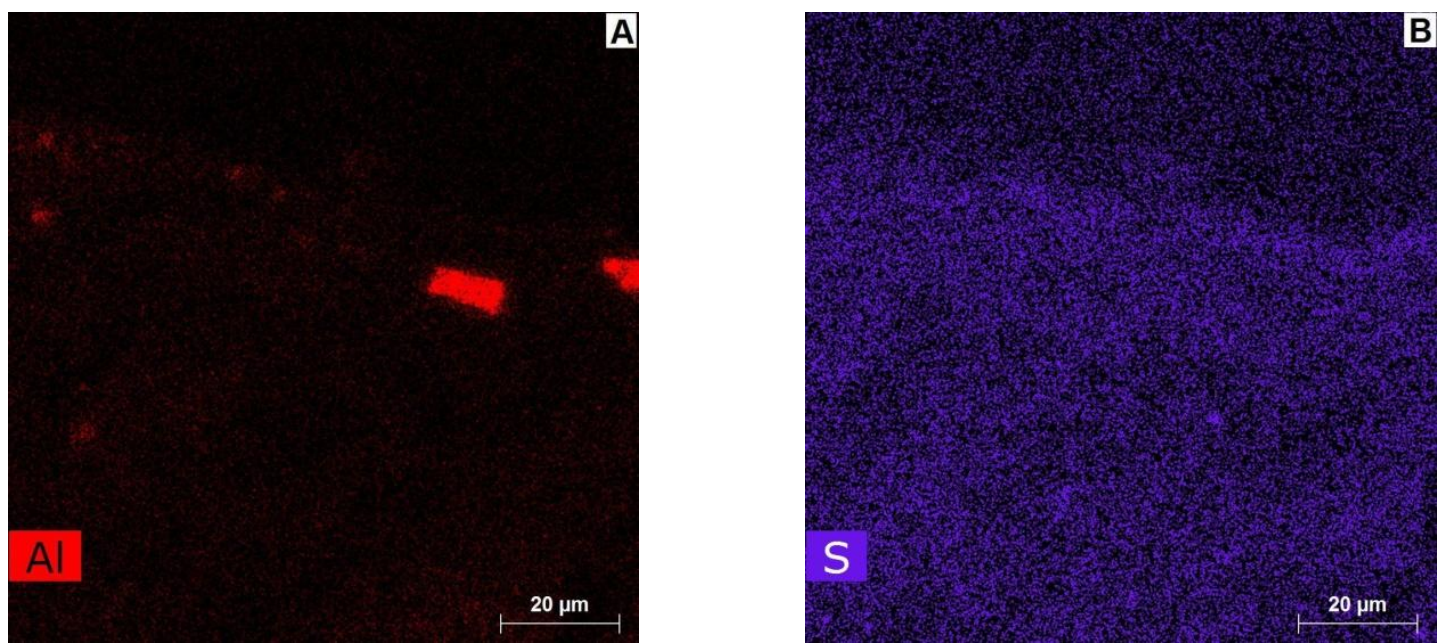

Figura 97: Mapeamentos composicionais por EDS na segunda área analisada da amostra 05. A: Mapeamento do elemento Al; B: Mapeamento do elemento S.

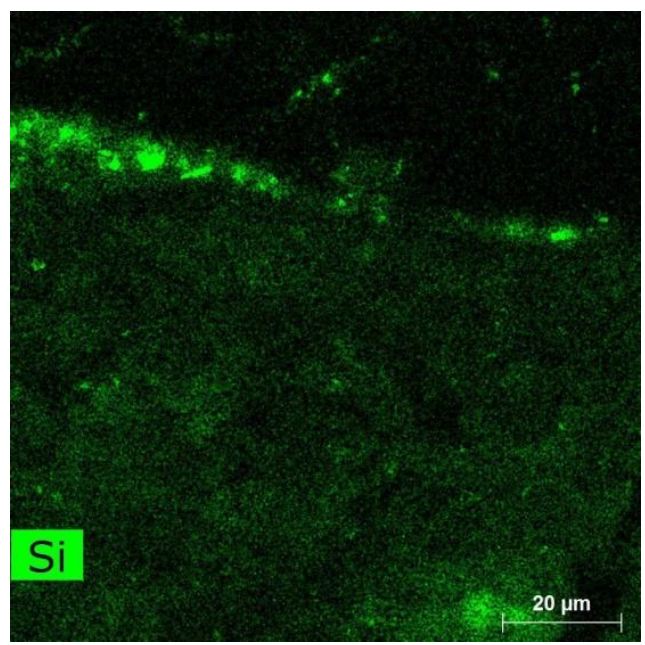

Figura 98: Mapeamento pelo EDS do elemento Si na segunda área analisada da amostra 05. 


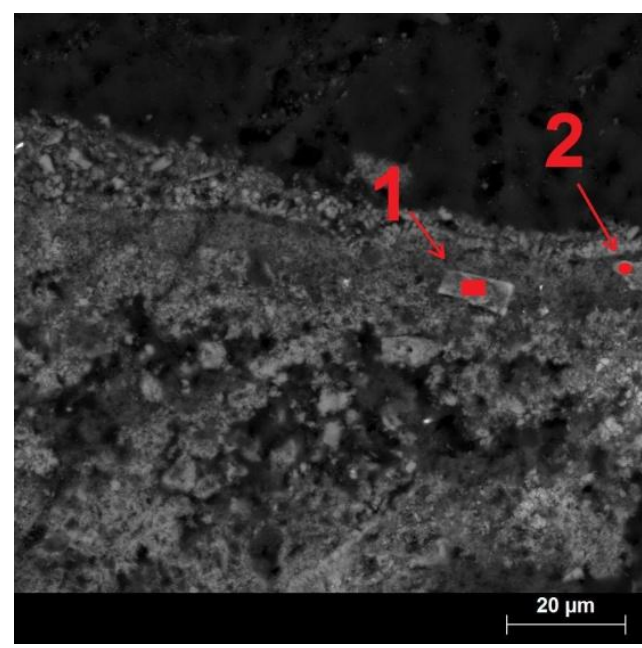

Figura 99: Indicados com os números 1 e 2, respectivamente, uma área retangular e um ponto, de onde foram lidos os espectros composicionais apresentados nas Figuras 100 e 101.

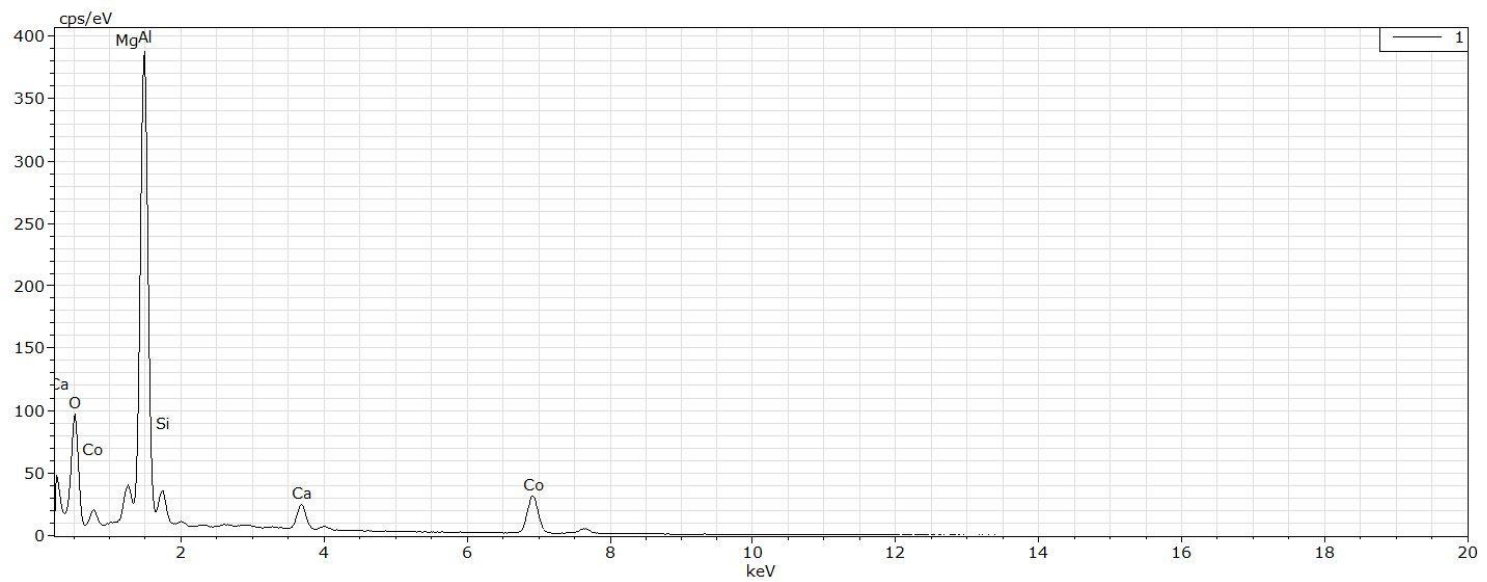

Figura 100: Espectro composicional por EDS da região (sobre grão interpretado como pigmento azul cobalto) assinalada com o número '1' na Figura 99.

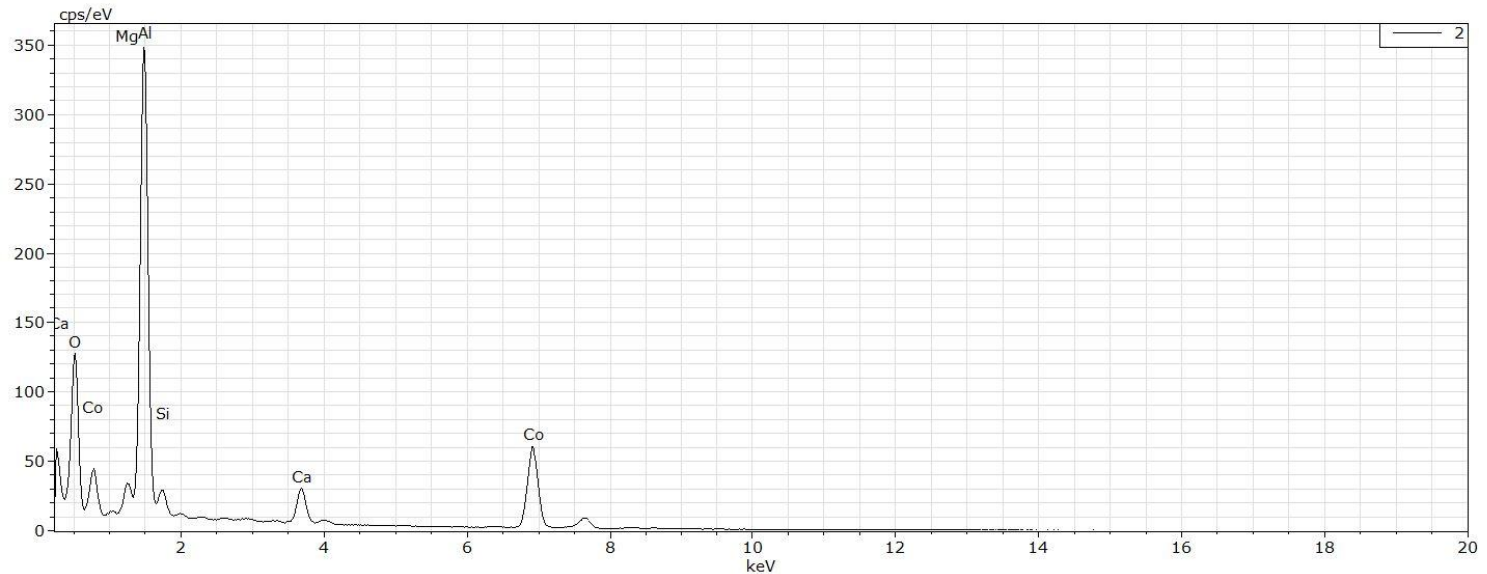

Figura 101: Espectro composicional por EDS da região (sobre grão interpretado como pigmento azul cobalto) assinalada com o número '2' na Figura 99. 
As Figuras $102_{\mathrm{A}}, 102_{\mathrm{B}}, 104_{\mathrm{A}}$ e $104_{\mathrm{B}}$ mostram a quarta e quinta áreas da amostra 05 analisadas em MEV/EDS, ambas como resultado da identificação da barita - mineral usado como pigmento branco, já encontrado anteriormente em murais executados a fresco por Fulvio Pennacchi (Del Lama, 2006; Del Lama et al., 2009). Os espectros composicionais de ambos os grãos analisados (Figuras 103 e 105) mostram a presença da barita misturada à argamassa.
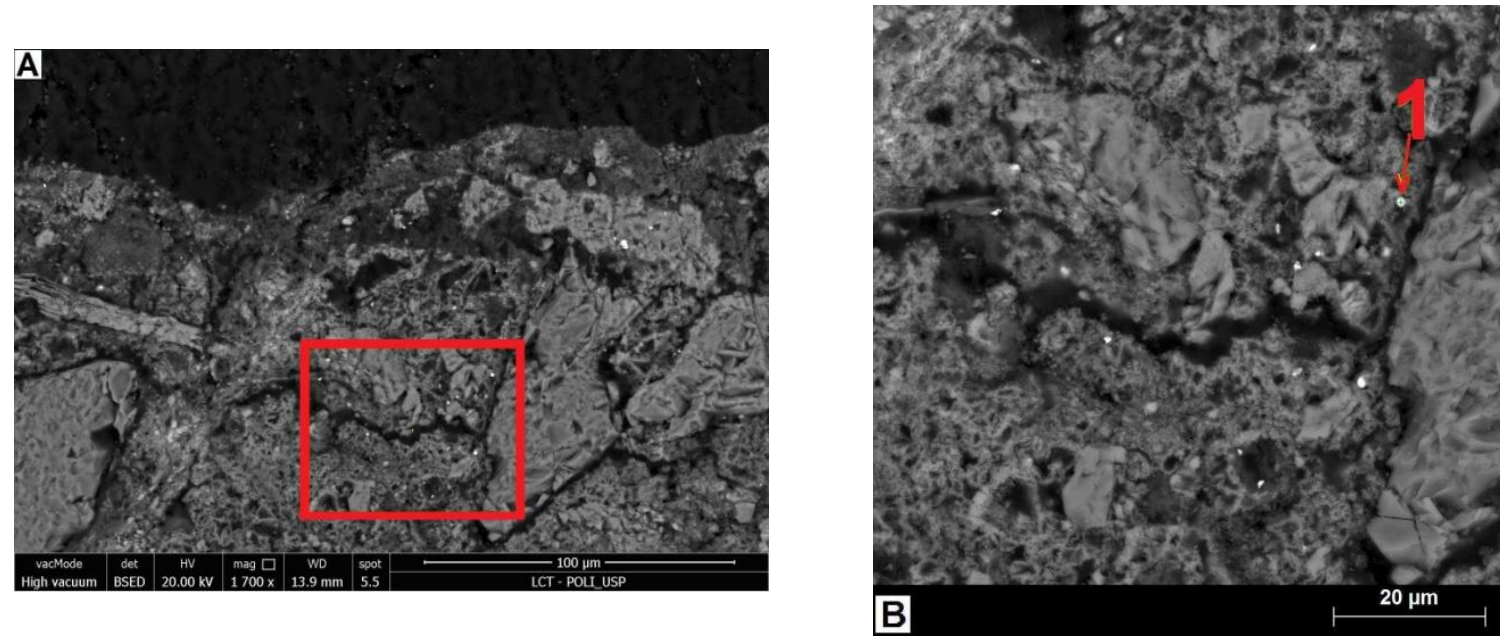

Figura 102A: Quarta área analisada em MEV/EDS da amostra 05, com enfoque na superfície. A área marcada para ampliação foi escolhida por conter concentração significativa de grãos de barita. $102_{\mathrm{B}}$ : ampliação da área marcada na Figura $102_{\mathrm{A}}$. O número ' 1 ' indica o ponto onde foi feita leitura dos elementos por EDS, cujo espectro está apresentado na Figura 103.

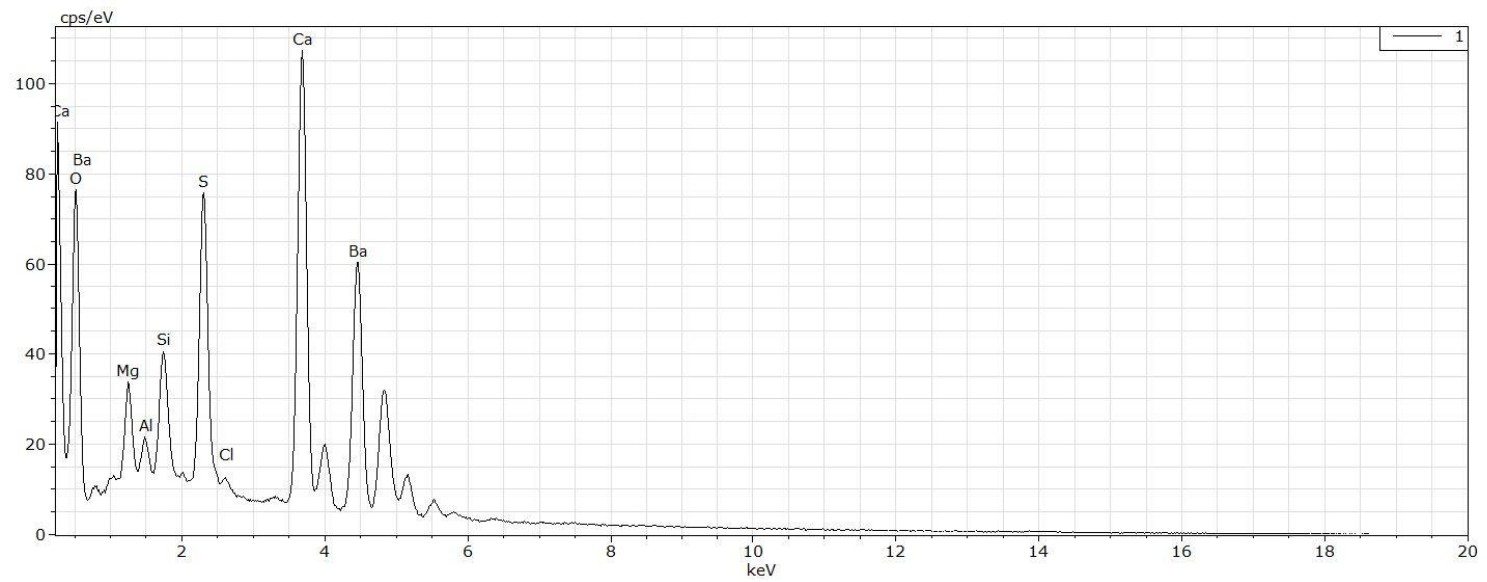

Figura 103: Espectro composicional do ponto '1', marcado na Figura $102_{B}$, analisado por EDS. 

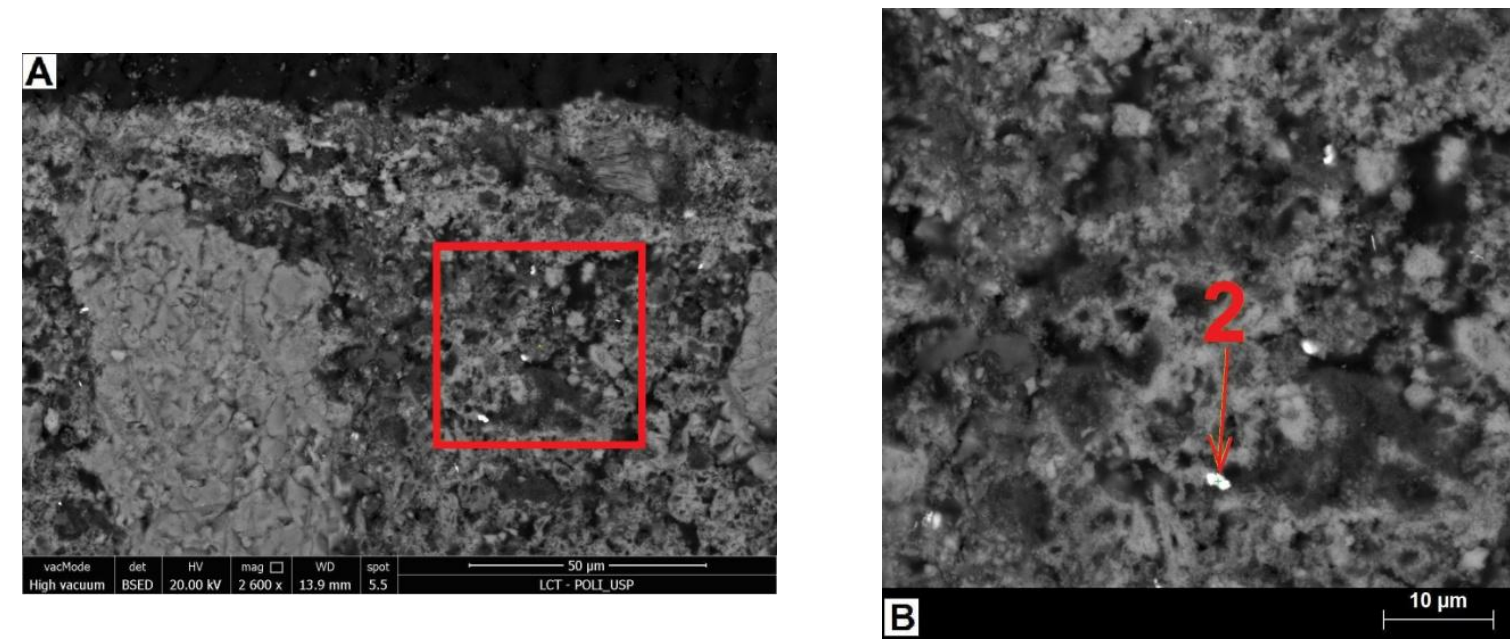

Figura 104A: Quinta área analisada em MEV/EDS da amostra 05, com enfoque na superfície. A área marcada para ampliação apresenta concentração significativa de grãos de barita. 104 ${ }_{\mathrm{B}}$ : ampliação da área marcada na Figura $104_{\mathrm{A}}$. O número '2' indica o ponto onde foi feita leitura dos elementos por EDS, cujo espectro está apresentado na Figura 105.

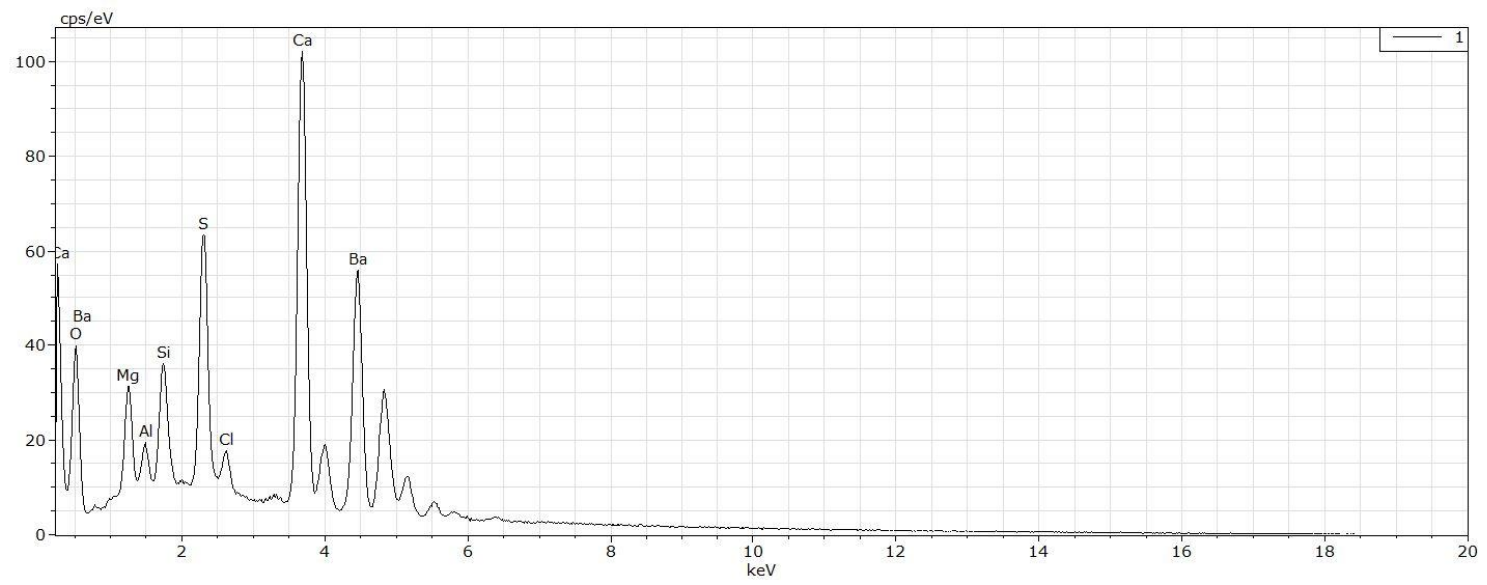

Figura 105: Espectro composicional do ponto '2', marcado na Figura 104 analisado por EDS. 


\subsection{3b MEV/EDS - SUPERFÍCIE PICTÓRICA}

Foram feitas também análises em MEV da superfície da amostra 05. Na Figura 106 está a imagem dos fragmentos coletados.

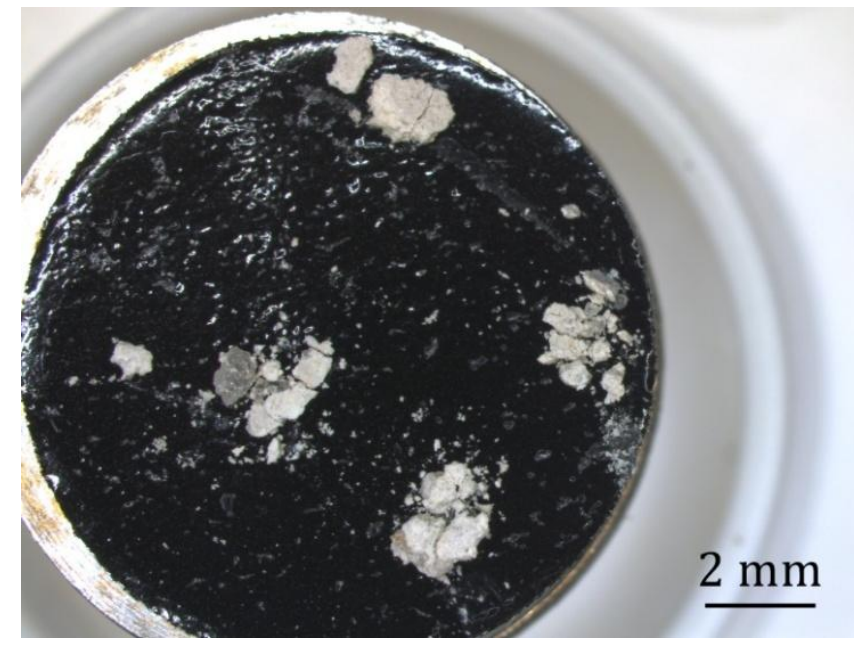

Figura 106: Stube (suporte de amostras para MEV) contendo fragmentos da superfície da amostra 05.

Nas Figuras $107_{A}$ e $107_{B}$ vemos imagens aproximadas dos fragmentos da superfície da amostra 05. Grãos azuis são visíveis por toda a área, sendo estes os grãos de pigmento azul cobalto já descritos anteriormente.
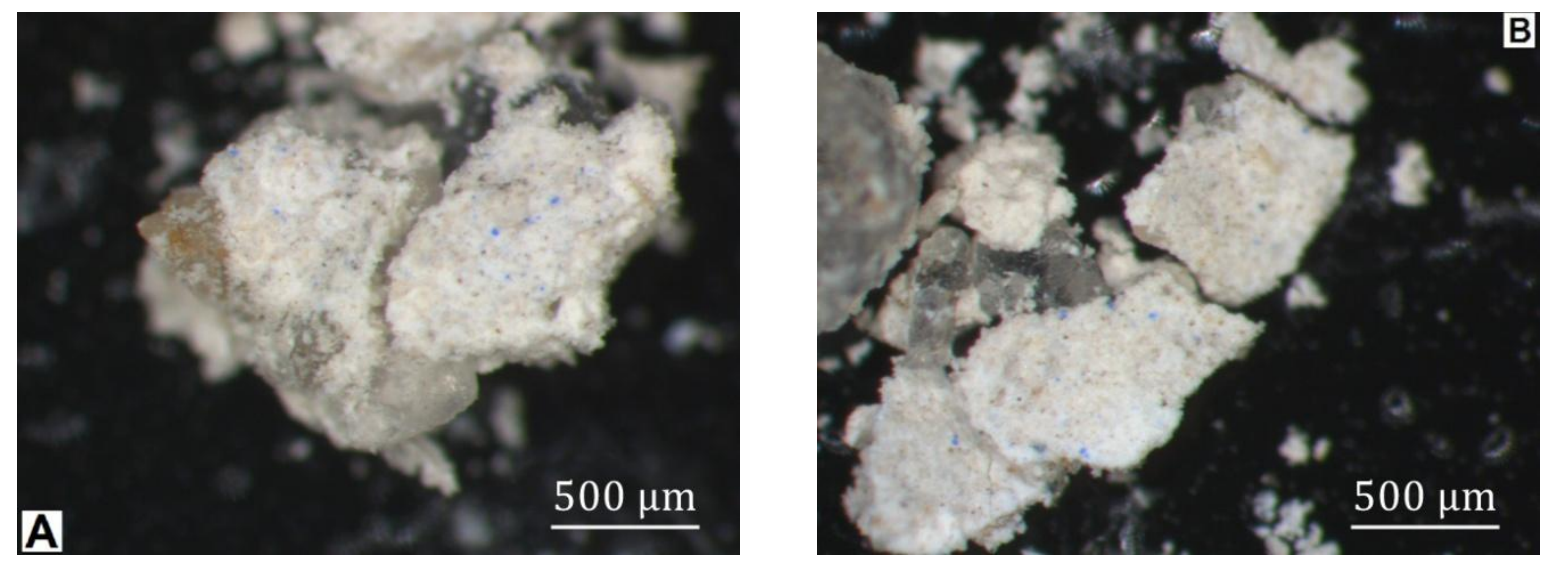

Figuras $107_{\mathrm{A}}$ e 107 : Fragmentos da superfície da amostra 05 analisados no MEV. 
A Figura 108 mostra a superfície rugosa da amostra 05, similar à da amostra 01 (Figura 28), também composta de argamassa rica em cálcio. A Figura $109_{B}$ mostra o trecho da superfície onde foram feitos os mapeamentos composicionais por EDS.

$\mathrm{O}$ pigmento azul cobalto que contém alumínio possui fórmula química $\mathrm{CoAl}_{2} \mathrm{O}_{4}$ (Buxbaum, 2008). Nos mapeamentos composicionais das Figuras $110_{\mathrm{A}}$ e $110_{\mathrm{B}}$ vemos mais uma vez a presença de grãos deste pigmento por toda a superfície desta amostra.

A Figura $109_{B}$ mostra o mapeamento do elemento $\mathrm{Si}$, que aparece na forma de grãos, interpretados aqui como agregados presentes na água de cal usada como veículo para a aplicação do pigmento azul. 


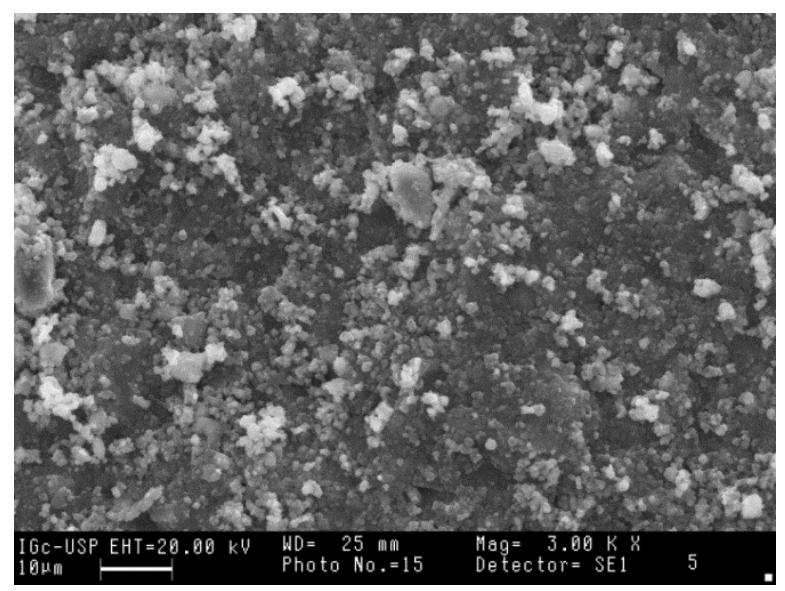

Figura 108: Superfície rugosa da amostra 05. Imagem de elétrons secundários.
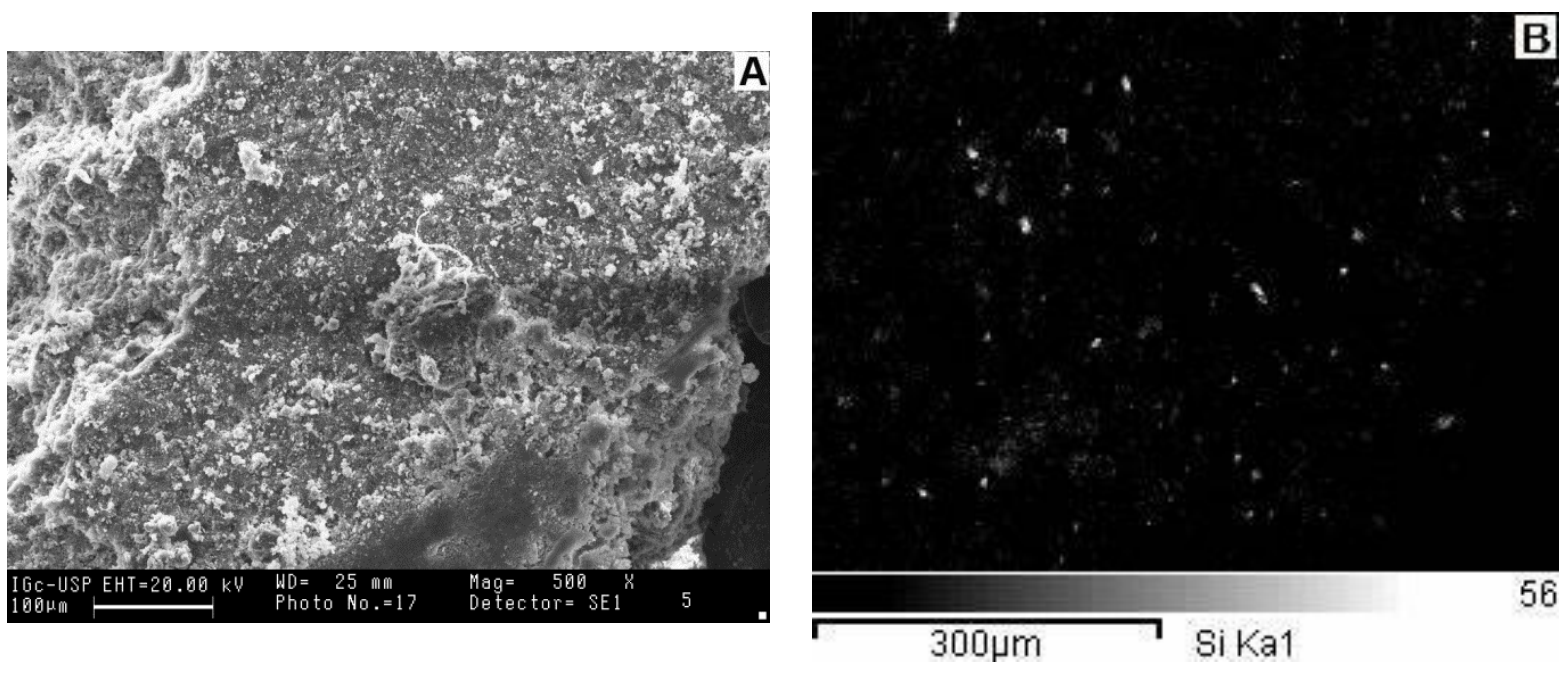

Figura 109 $\mathrm{A}$ : Região submetida a mapeamento composicional por EDS. 109 $\mathrm{B}$ : Mapeamento composicional do elemento Si na superfície da amostra 05.
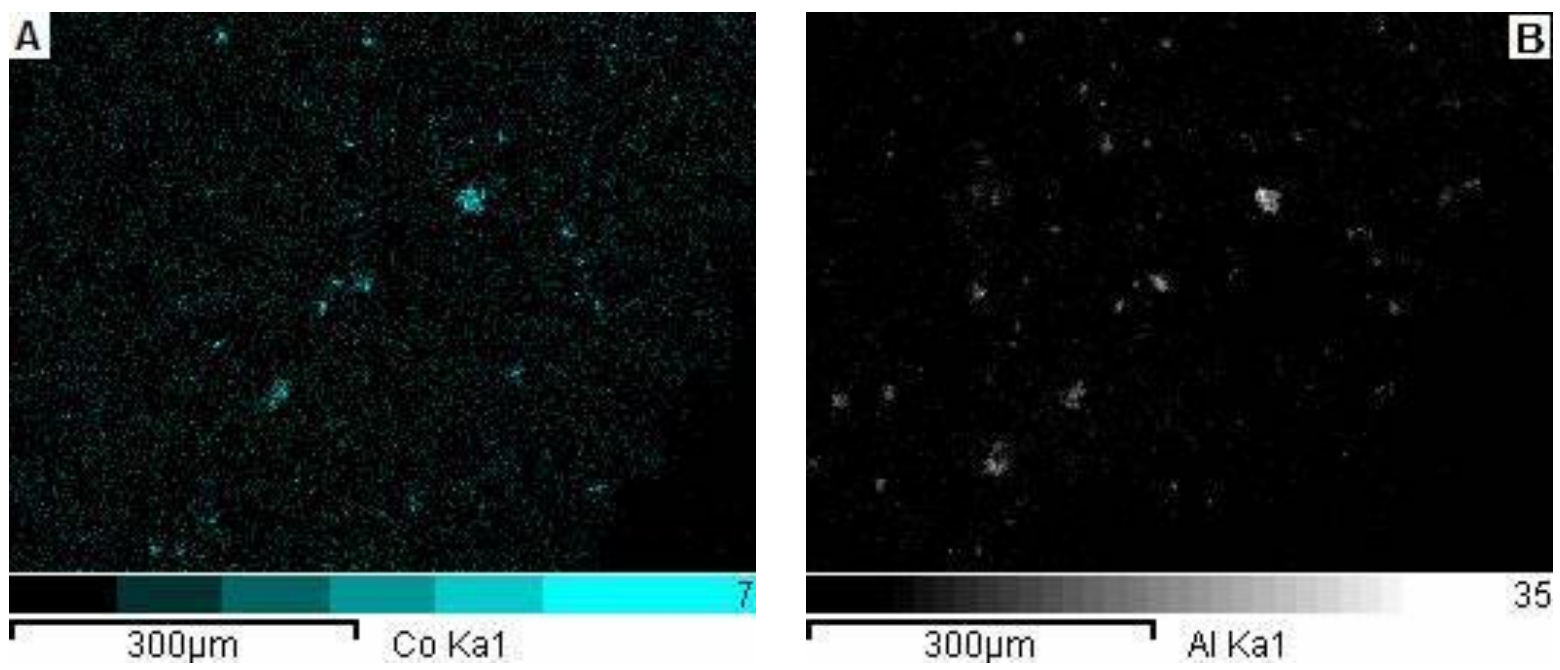

Figura 110: Mapeamentos composicionais feitos na superfície da amostra 05. A: Mapeamento do elemento Co. B: Mapeamento do elemento Al. 


\subsubsection{FLUORESCÊNCIA DE RAIOS X}

Os dados da FRX semiquantitativa de varredura superficial mostram a composição da argamassa usada para compor a camada pictórica, com abundância de $\mathrm{Ca}$ em relação a Mg. O Si está presente na superfície em forma de agregados, e o S como adição de gesso. Al e Co são os componentes do pigmento azul (Tabela 5).

Tabela 5: Dados semiquantitativos (\%) de espectrometria de fluorescência de raios $\mathrm{X}$ de varredura superficial, de todas as amostras para comparação.

\begin{tabular}{|c|c|c|c|c|c|}
\hline AMOSTRA & 01 & 02 & 03 & 04 & 05 \\
\hline Sum sem norm. & 75,7 & 88,8 & 67,3 & 82,7 & 66,4 \\
\hline & & & & & \\
\hline $\mathrm{Na}_{2} \mathrm{O}$ & 0,14 & 0,096 & 0,111 & 0,073 & 0,118 \\
\hline $\mathrm{MgO}$ & 5,177 & 4,533 & 47,342 & 4,902 & 9,187 \\
\hline $\mathrm{Al}_{2} \mathrm{O}_{3}$ & 3,662 & 4,341 & 3,478 & 6,188 & 6,812 \\
\hline $\mathrm{SiO}_{2}$ & 7,908 & 7,484 & 4,827 & 11,623 & 17,706 \\
\hline $\mathrm{P}_{2} \mathrm{O}_{5}$ & 0,094 & 0,291 & 0,091 & 0,184 & 0,263 \\
\hline $\mathrm{SO}_{3}$ & 5,834 & 1,179 & 0,517 & 0,828 & 2,105 \\
\hline $\mathrm{Cl}$ & 0,39 & 0,265 & 0,228 & 0,301 & 0,299 \\
\hline $\mathrm{K}_{2} \mathrm{O}$ & 0,31 & 0,419 & 0,208 & 1,16 & 0,541 \\
\hline $\mathrm{CaO}$ & 70,313 & 46,736 & 40,688 & 43,212 & 59,214 \\
\hline $\mathrm{TiO}_{2}$ & 2,614 & 33,64 & 0,777 & 30,615 & \\
\hline $\mathrm{Cr}$ & 0,013 & 0,018 & 0,012 & 0,026 & 0,019 \\
\hline $\mathrm{MnO}$ & 0,078 & 0,035 & 0,044 & 0,007 & \\
\hline $\mathrm{Fe}_{2} \mathrm{O}_{3}$ & 3,228 & 0,638 & 1,335 & 0,482 & 2,43 \\
\hline $\mathrm{Ni}$ & 0,004 & 0,005 & 0,007 & 0,005 & 0,006 \\
\hline $\mathrm{Cu}$ & 0,018 & 0,018 & 0,037 & 0,01 & 0,022 \\
\hline $\mathrm{Zn}$ & 0,037 & 0,076 & 0,091 & 0,023 & 0,138 \\
\hline $\mathrm{Rb}$ & 0,005 & 0,007 & 0,009 & 0,007 & 0,006 \\
\hline $\mathrm{Sr}$ & 0,105 & 0,089 & 0,021 & 0,043 & 0,059 \\
\hline $\mathrm{Y}$ & 0,003 & 0,002 & 0,004 & 0,002 & 0,002 \\
\hline $\mathrm{Zr}$ & 0,033 & 0,031 & 0,038 & 0,019 & 0,027 \\
\hline $\mathrm{Ba}$ & 0,031 & 0,07 & 0,122 & 0,053 & 0,104 \\
\hline $\mathrm{Pb}$ & 0,004 & 0,019 & 0,011 & 0,011 & 0,015 \\
\hline $\mathrm{Br}$ & & & & & 0,002 \\
\hline $\mathrm{Ce}$ & & & & & 0,102 \\
\hline Co & & & & & 0,138 \\
\hline $\mathrm{F}$ & & & & 0,219 & 0,289 \\
\hline $\mathrm{Ga}$ & & 0,002 & & & \\
\hline $\mathrm{Mn}$ & & & & & 0,097 \\
\hline $\mathrm{Nb}$ & & 0,007 & & 0,008 & \\
\hline $\mathrm{Ti}$ & & & & & 0,298 \\
\hline
\end{tabular}




\subsubsection{LANTERNA UV}

Sob incidência de radiação UV, a superfície da amostra 05 se comporta de maneira heterogênea (Figuras 111 A, e 111 B para comparação), emitindo luz com diferentes tons de azul, com exceção das porções afetadas pelo incêndio, que permanecem escuras.
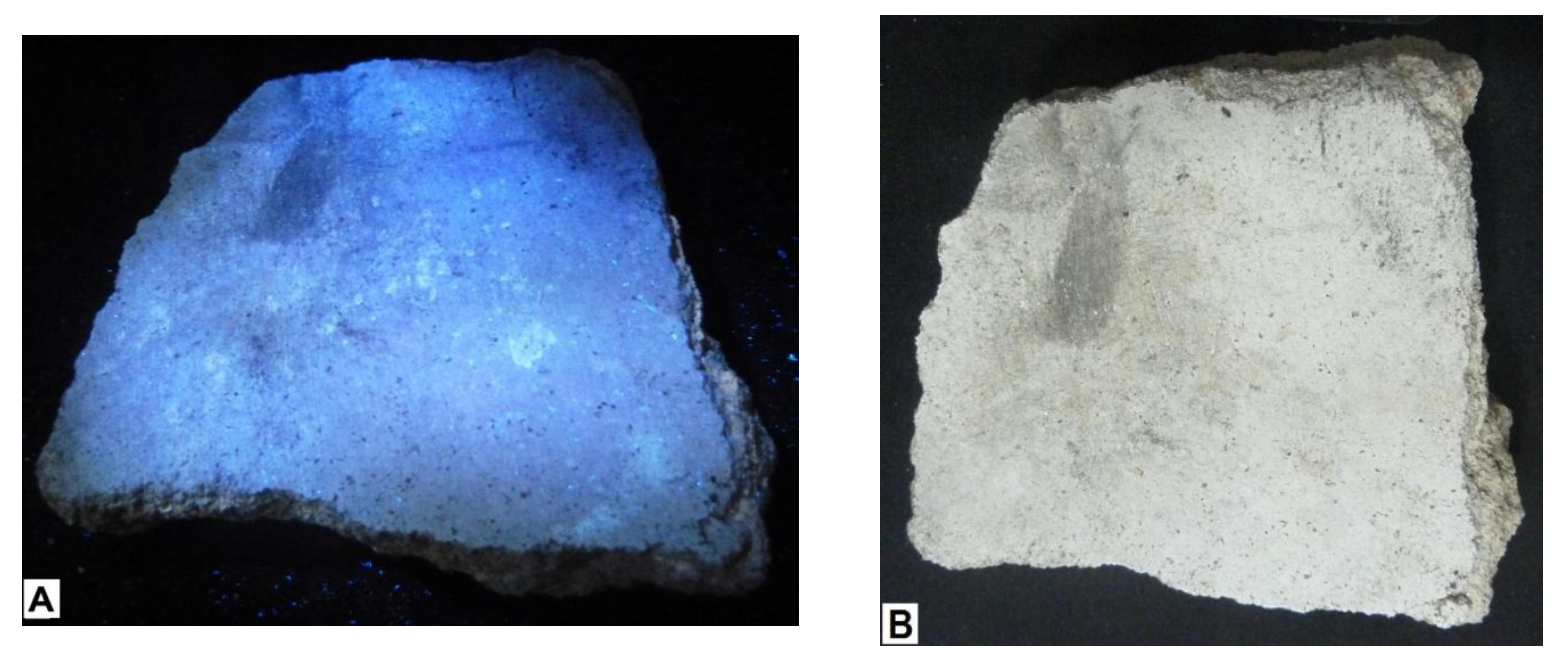

Figura 111 $1_{\mathrm{A}}$ : Amostra 05 iluminada por lanterna UV. 111 $\mathrm{B}$ : Amostra 05 sob iluminação ambiente para comparação. 


\subsubsection{CONCLUSÕES SOBRE A AMOSTRA 05}

A amostra 05 é composta por uma única camada de argamassa, aqui interpretada como camada pictórica aplicada pelo artista. Esta porção do mural foi feita sendo utilizada a técnica tradicional do afresco, também chamada de buon fresco ou vero fresco. Sobre esta camada ainda úmida, foi aplicado azul cobalto - pigmento comumente utilizado por Fulvio Pennacchi em seus afrescos (Andre, 1989; Wilhelm, 2006).

A conclusão de que a aplicação do pigmento se deu com a argamassa ainda úmida é possível pois seus grãos encontram-se imersos na superfície da camada, sendo englobados pelo aglomerante. Há associados aos grãos de pigmento agregados silicosos, principalmente grãos de quartzo, que estavam presentes na água de cal usada como veículo de aplicação do pigmento.

Há gesso e partículas de barita misturados na argamassa, sendo que uma concentração maior de $S$ nos micrômetros superficiais levam a crer que foi adicionado gesso também à água de cal contendo os pigmentos. 


\section{COMPARAÇÕES COM TRABALHOS ANTERIORES}

Del Lama et al. (2009) apresentam um estudo detalhado feito em dois murais de Fulvio Pennacchi - Anunciação da Virgem e Ceia de Emaús, localizados na cidade de São Paulo, na capela do Hospital das Clínicas da Faculdade de Medicina da Universidade de São Paulo, discutindo os materiais e as técnicas utilizadas por este pintor. Ambas as obras, elaboradas em 1947, apresentam similaridades com a obra estudada no presente trabalho, tendo sido feitas tanto com a técnica do afresco quanto com a do mezzo fresco. Um dos objetivos do presente trabalho - para além de estabelecer a mineralogia, composição química, texturas e estratigrafia das diferentes amostras do mural Alegoria ao Desenvolvimento Industrial Paulista - é colaborar com dados históricos a respeito do modo de feitura das obras de Fulvio Pennacchi.

No trabalho supracitado, observou-se que duas texturas diferentes resultam do modo de aplicação dos materiais por Pennacchi: a primeira (textura tipo 1) refere-se a porções executadas com a técnica pura do afresco - com os pigmentos incorporados na superfície da camada externa de argamassa, e a segunda (textura tipo 2) revela porções em que uma fina camada de material pigmentado, com composição química similar à da argamassa, recobre a camada externa - há uma película carbonática entre ambas, visível nas imagens de MEV, evidenciando que a camada de argamassa já se encontrava seca ou semisseca quando o material pigmentado foi aplicado.

Conforme demonstrado no item 5 (Resultados), a amostra 05 apresenta textura tipo 1 , e as amostras 01 e 03 apresentam textura tipo 2.

Cabem aqui duas observações. Em primeiro lugar, no trabalho de Del Lama et al. (2009) foi usado o termo a secco para denominar a técnica que resulta na textura tipo 2; aqui, foi usado o termo mezzo fresco. Conforme apresentado no item 1 (Introdução), há controvérsias a respeito dos termos usados para designar estas técnicas e suas variações.

Em segundo lugar, tanto na amostra 01 quanto na 03 , por sobre a camada externa de argamassa já seca (ou semisseca), o artista aplicou primeiro uma demão de cal, 
para em seguida aplicar os materiais colorantes. Na amostra 01, os pigmentos se incorporaram à superfície desta demão; na 03, uma camada de argamassa de cor cinza foi aplicada por cima da referida demão de cal.

Tanto nos murais do Hospital das Clínicas quanto no mural analisado no presente trabalho, o aglomerante de todas as camadas é composto de material carbonático, com proporções variadas de $\mathrm{Ca}$ e $\mathrm{Mg}$, e os agregados, quando presentes, são majoritariamente de grãos de quartzo angulosos.

Outra semelhança entre os murais é a presença de enxofre na camada pictórica, resultado da mistura de gesso com a finalidade de produzir efeitos estéticos. No trabalho de 2009, este elemento foi identificado nas porções com textura tipo 2; aqui, foi encontrado enxofre tanto na amostra 01, que também apresenta textura tipo 2 , quanto na 05 , de textura tipo 1.

A presença de fibras foi detectada em todos os murais, misturadas à argamassa.

Quanto aos pigmentos, o mais abundante encontrado no trabalho de 2009 foi a barita, aqui encontrada na amostra 05. Lá também foram detectados pigmentos de Fe e Ti, como na amostra 01 do presente trabalho (além de outros não identificados aqui).

Traços do mineral turmalina, identificados no agregado usado nos murais Anunciação da Virgem e Ceia de Emaús, também foram aqui reconhecidos, como mostram as Figuras 112 a 114. Este é um mineral presente nas areias aluvionares dos rios Tietê e Pinheiros (Suguio \& Takahashi, 1970), que provavelmente foram as fontes dos agregados usados por Pennacchi em seus afrescos. 

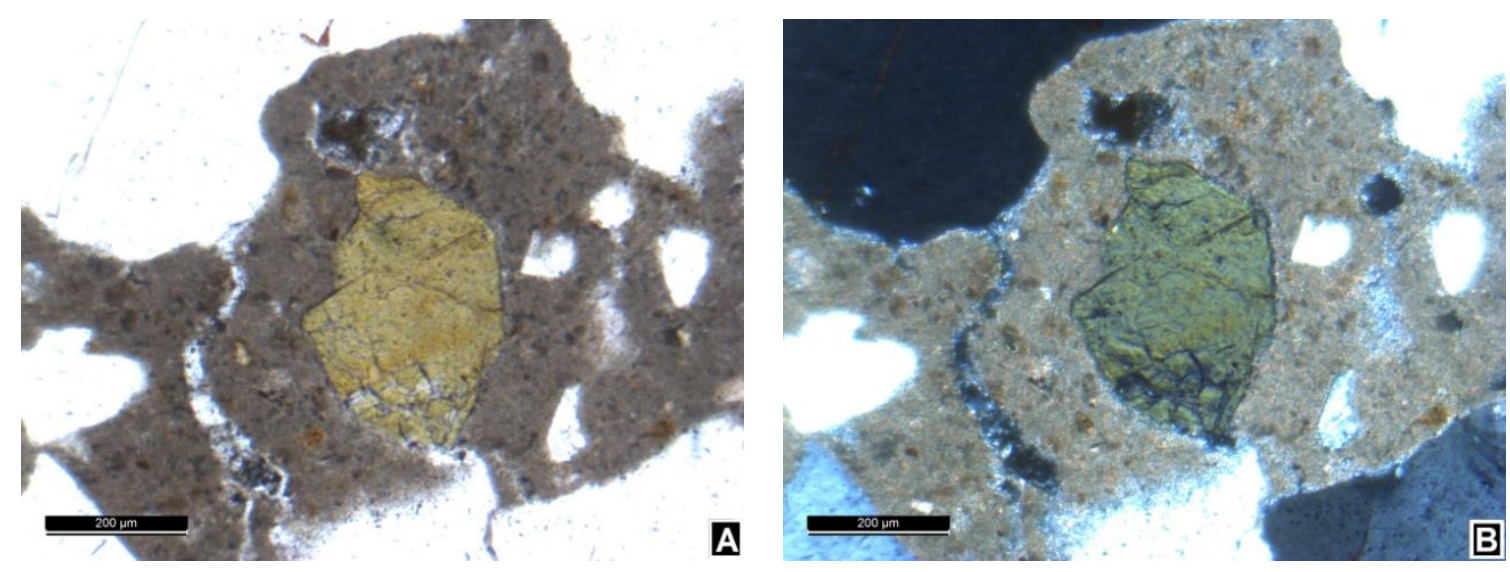

Figura 112: Fotomicrografia da amostra 01 . Em destaque um grão do mineral turmalina, presente no agregado da camada preparatória. A: Polarizadores paralelos. B: Polarizadores cruzados.
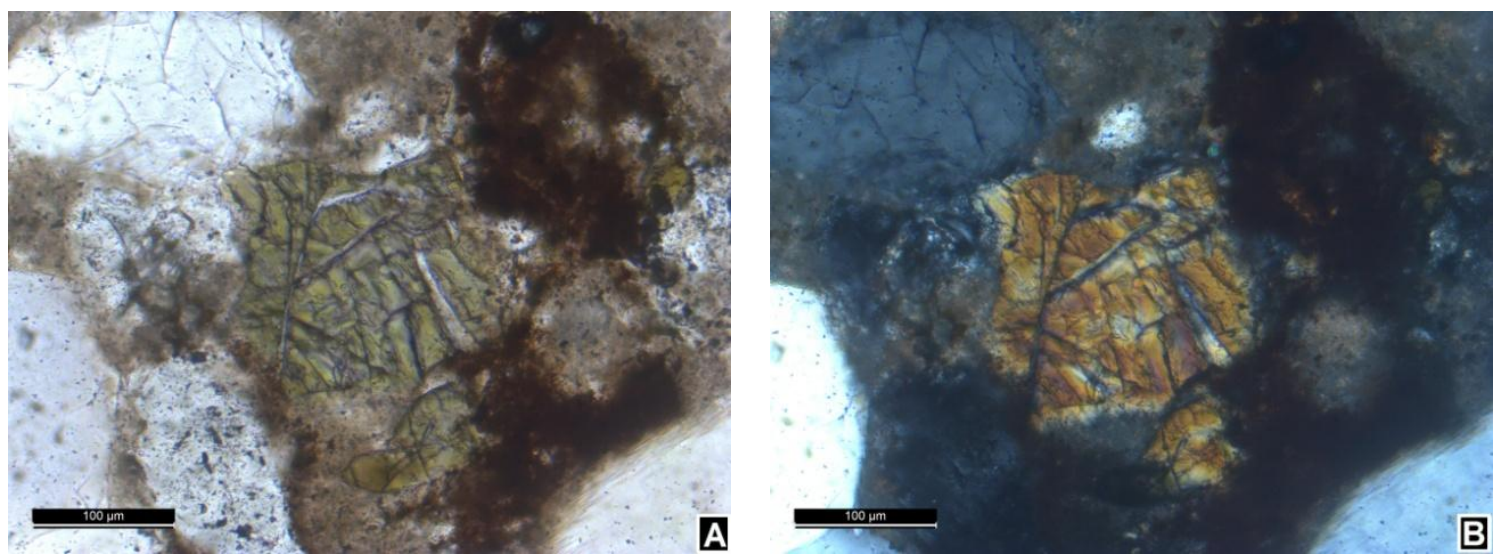

Figura 113: Fotomicrografia da amostra 03. Em destaque um grão do mineral turmalina, presente no agregado da camada preparatória. A: Polarizadores paralelos. B: Polarizadores cruzados.
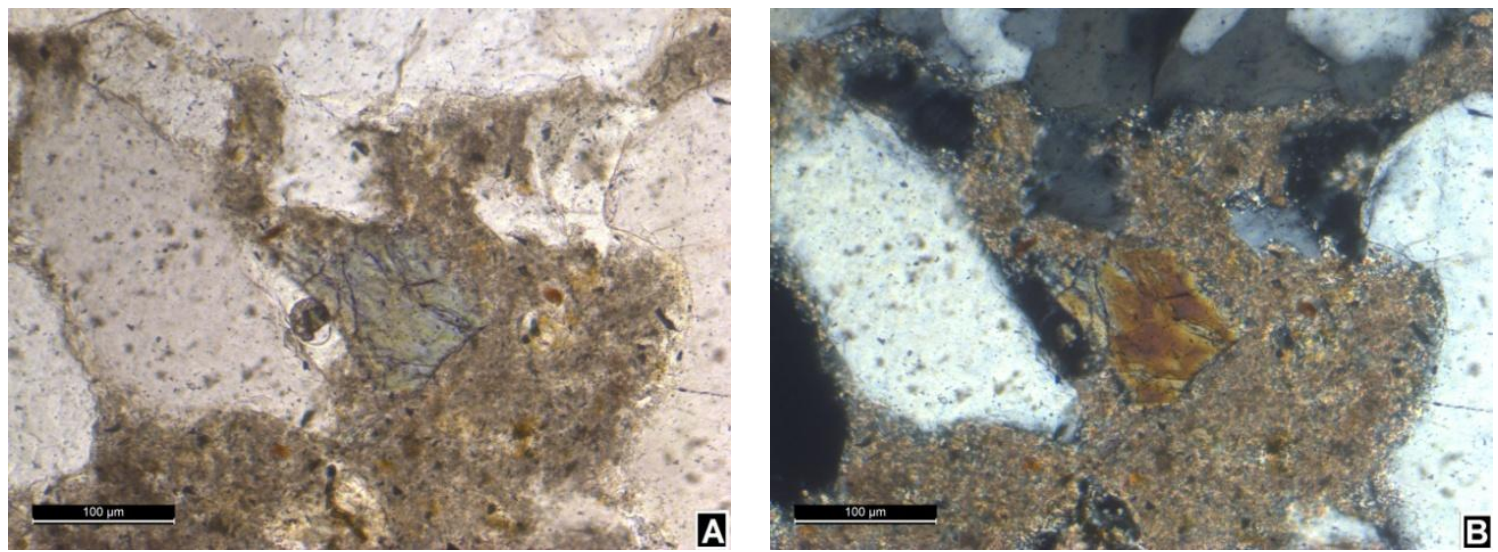

Figura 114: Fotomicrografia da amostra 05 . Em destaque um grão do mineral turmalina, presente no agregado da camada preparatória. A: Polarizadores paralelos. B: Polarizadores cruzados. 


\section{CONCLUSÕES}

Das cinco amostras analisadas, três são parte da pintura mural original objeto de estudo deste trabalho - as amostras 01, 03 e 05. As amostras 02 e 04 são fruto de reforma feita no local, posterior à confecção do mural.

Uma delas - a amostra 05 - expõe parte da obra que foi executada com a técnica pura do afresco, também chamada de buon fresco ou vero fresco. Nela, as partículas de pigmento azul cobalto encontram-se imersas na superfície da camada de argamassa externa da parede, evidenciando que a aplicação do pigmento foi feita enquanto esta última encontrava-se úmida.

As amostras 01 e 03 revelam porções da obra não executadas com a técnica pura do afresco, podendo ser nesses casos chamada de mezzo fresco.

Tanto na amostra 01 como na 03, sobre o reboco já seco ou semisseco, o artista aplicou uma demão de cal, resultando numa camada irregular e bastante delgada. Em seguida fez a aplicação dos materiais colorantes.

No caso da amostra 01, o artista usou uma mistura de óxido de titânio e óxido de ferro, que resultou na cor rosa da superfície. Esses pigmentos foram diluídos para serem então aplicados sobre a camada delgada de cal ainda úmida, assim proporcionando a penetração dos grãos de pigmento nos micrômetros superficiais desta última.

$\mathrm{Na}$ amostra 03, o material colorante que o artista aplicou foi argamassa de composição magnesiana contendo agregados muito finos. Não foram identificados pigmentos nesta última, portanto concluiu-se que a cor cinza neste caso é resultado da própria composição desta argamassa. A interface entre a demão de cal e essa argamassa cinza apresenta uma película evidenciando o já iniciado processo de carbonatação da demão de cal, mas é nítida a interação entre os dois materiais, com a argamassa cinza penetrando nos micrômetros superficiais da camada subjacente. Esse fato deixa claro que a demão de cal ainda continha quantidade significativa de umidade no momento da aplicação do material colorante. 
Em conformidade com a literatura (Quedas, 2004; Wilhelm, 2006; Del Lama et al., 2009), o conjunto de dados referentes aos estudos envolvendo os afrescos de Fulvio Pennacchi mostram que o artista mesclava técnicas, usando a do buon fresco e a do mezzo fresco e suas variações, ao longo de seus murais.

Após o incêndio ocorrido no imóvel onde o mural se encontrava originalmente, especialistas removeram a obra, que atualmente se encontra guardada. Seu atual dono foi contatado, mas infelizmente o acesso à obra não foi possível, pois sua superfície encontra-se coberta por uma camada de gesso, aparentemente aplicada com o intuito de protegê-la.

Vale ressaltar a importância de se ter coletado as amostras - usadas neste estudo após o incêndio referido acima. Apesar de não termos as coordenadas precisas do local de onde cada um destes fragmentos se soltou, sabemos de qual região da obra eles pertenciam (Figura 4), e o mais importante: esses fragmentos seriam descartados, e em posse deles tivemos a oportunidade de conhecer a estratigrafia completa de porções da obra, oportunidade nem sempre comum no universo da conservação e restauração, em que na maioria das vezes somente técnicas não invasivas podem ser aplicadas, ou quando há a possibilidade de coleta de amostras, estas deveriam ser necessariamente microamostras. 


\section{REFERÊNCIAS BIBLIOGRÁFICAS}

ANDRE, M.C.C.R. Catalogação de painéis e murais da cidade de São Paulo: espaços públicos e semi-públicos. S.I. : S.N., 192p., 1989.

ANGHINETTI, I.C.B. Tintas, suas propriedades e aplicações imobiliárias. Monografia apresentada ao Curso de Especialização em Construção Civil da Escola de Engenharia da UFMG. Belo Horizonte, 2012.

BARDI, P.M. Fulvio Pennacchi. Ed. Raízes, São Paulo, 187p., 1980.

BARNETT, J.R.; MILLER, S.; PEARCE, E. Colour and art: A brief history of pigments. Optics \& Laser Technology, v.38, n.4, p.445-453, 2006.

BARRIO, N. O exame da fluorescência da pintura. In: MENDES, M.; BATISTA, A.C.N (org). Restauração: ciência e arte. Editora IRFJ/IPHAN, Rio de Janeiro, p. 285-322, 2005.

BUXBAUM, G. (ed). Industrial inorganic pigments. Wiley-VCH, Weinheim, 300p., 2005.

CASELLATO, U.; VIGATO, P.A.; RUSSO, U.; MATTEINI, M. A Mössbauer approach to the physico-chemical characterization of iron-containing pigments for historical wall paintings. Journal of Cultural Heritage, v.1, n.3, p.217-232, 2000.

CENNINI, C. The Craftsman's Handbook: Do italiano "Il Libro Dell'Arte", 1398. Traduzido por Daniel V. Thompson. Dover Publications, Inc., New York, 1933.

CENNI, F. Italianos no Brasil: "andiamo in'merica". Martins, São Paulo, 438p., 1975.

COSENTINO, A. Identification of pigments by multispectral imaging; a flowchart method. Heritage Science, v.2, n.8, p.8-20, 2014.

DASSER, K.L. Pretreatment examination and documentation: the wall paintings of Schloß Seehof, Bamberg. In: CATHER, S. (ed). The conservation of wall paintings; proceedings of a symposium organized by the Courtauld Institute of Art and the Getty 
Conservation Institute, London, July 13-16 1987. Getty Conservation Institute. p.2127, 1991.

DEDAVID, B.A.; GOMES, C.I.; MACHADO, G. (org). Microscopia eletrônica de varredura: aplicações e preparação de amostras. EDIPUCRS, Porto Alegre, 60p., 2007.

DEL LAMA, E.A. A mineralogia aplicada ao estudo de pinturas murais: Fulvio Pennacchi - um estudo de caso. Relatório de atividades apresentado à FAPESP, projeto número 2005/51310-3. 2006.

DEL LAMA, E.A. Instituto de Geociências da USP e herança cultural: estreitando os laços. Revista CPC, São Paulo, n.7, p.173-182, 2009.

DEL LAMA, E.A.; ANDRADE, F.R.D.; KIHARA, Y.; TIRELLO, R.A. Estudo de eflorescências em pinturas murais de Fulvio Pennacchi. ARC - Revista Brasileira de Arqueometria, Restauração e Conservação. v.1, n.3, p.92-95, 2007.

DEL LAMA, E.A.; TIRELLO, R.A.; ANDRADE, F.R.D.; KIHARA, Y. Study of mural paintings by Fulvio Pennacchi in São Paulo City by mineralogical techniques. Anais da Academia Brasileira de Ciências, v.81, n.1, p.115-126, 2009.

DONATO, M. O mundo do plástico; o plástico na história, o plástico no mundo, o plástico no Brasil. Goyana, São Paulo, 78p, 1972.

HRADIL, D.; GRYGAR, T.; HRADILOVÁ, J.; BEZDIČKA, P. Clay and iron oxide pigments in the history of painting. Applied Clay Science, v.22, n.5, p.223-236, 2003.

MARGALHA, M.G. Argamassas. Documento de apoio às aulas de Conservação e Recuperação do Património, Universidade de Évora, 2011.

MATTEINI, M. In Review: An Assessment of Florentine Methods of Wall Painting Conservation Based. In: CATHER, S. (ed). The conservation of wall paintings; proceedings of a symposium organized by the Courtauld Institute of Art and the Getty Conservation Institute, London, July 13-16 1987. Getty Conservation Institute. p.137148, 1991. 
MAYER, R. Manual do artista de técnicas e materiais. Martins Fontes, São Paulo, 838p., 2002.

MORA P.; MORA L.; PHILIPPOT P. Conservation of Wall Paintings. Butterworths, London, 494 p., 1984.

PENNACCHI, V.A. Fulvio Pennacchi, pintor, desenhista, muralista e ceramista. Disponível em: <,>. Acesso em: 25ago.2014.

QUEDAS, A.R. Pennacchi, afresco e pioneirismo em São Paulo. Dissertação de Mestrado apresentada ao Instituto de Artes da UNESP, 2004.

REYS, A.C.; DEL LAMA, E.A.; DEHIRA, L.K. Monumentos da cidade de São Paulo: formas de alteração e conservação. Revista CPC, São Paulo, n.5, p.93-122, 2008.

RIZZUTO, M.A. Técnicas físicas utilizadas no estudo de objetos de arte, arqueológicos e do patrimônio cultural. Tese de Livre Docência apresentada ao Instituto de Física da Universidade de São Paulo, 2014.

ROCK-COLOR CHART COMMITTEE. Rock-Color Chart: With Genuine Munsell Color Chips. Geological Society of America, 1963.

STUART, B.H. Analytical techniques in materials conservation. John Wiley \& Sons, Chichester, 424p., 2007.

SUGUIO, K.; TAKAHASHI, L.I. Estudo dos aluviões antigos dos rios Pinheiros e Tietê, São Paulo, SP. Anais da Academia Brasileira de Ciências, v.42, n.3, p.555$570,1970$.

TAVARES, M.L. A conservação e o restauro de revestimentos exteriores de edíficios antigos: uma metodologia de estudo e reparação. Tese de Doutorado apresentada ao Laboratório Nacional de Engenharia Civil, Lisboa, 2011.

TIRELLO, R.A. (org): O restauro de um mural moderno na USP: o afresco de Carlos Magano; CPC-PRCEU-USP, São Paulo, 204p., 2001. 
TIRELLO, R.A. Afresco de Fulvio Pennacchi na capela do Hospital das Clínicas da FMUSP: estudos científicos de caracterização material e executiva. Revista CPC, São Paulo, v.1 n.1, p.103-120, 2006.

TIRELLO, R.A.; DEL LAMA, E.A. La pintura al fresco moderna brasileña: estudios de caracterización material y ejecución de los murales de Fulvio Pennacchi (São Paulo/ Brasil). Anais do 1ํㅡㄹ Congreso Argentino de Arqueometría, Rosario, Argentina, 2005.

WILHELM, V.R.B. A Arte Mural do Grupo Santa Helena: um estudo para preservação. Tese de Doutorado apresentada à Faculdade de Arquitetura e Urbanismo da Universidade de São Paulo, 2006.

http://www.abcp.org.br/cms/basico-sobre-cimento/historia/uma-breve-historia-docimento-portland/

https://noticias.terra.com.br/brasil/cidades/vc-reporter-incendio-em-loja-revela-obrade-arte-em-sao-paulo,294b68f40d94b310VgnCLD200000bbcceb0aRCRD.html 